\title{
LINHISTIBA 3
}

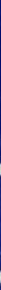

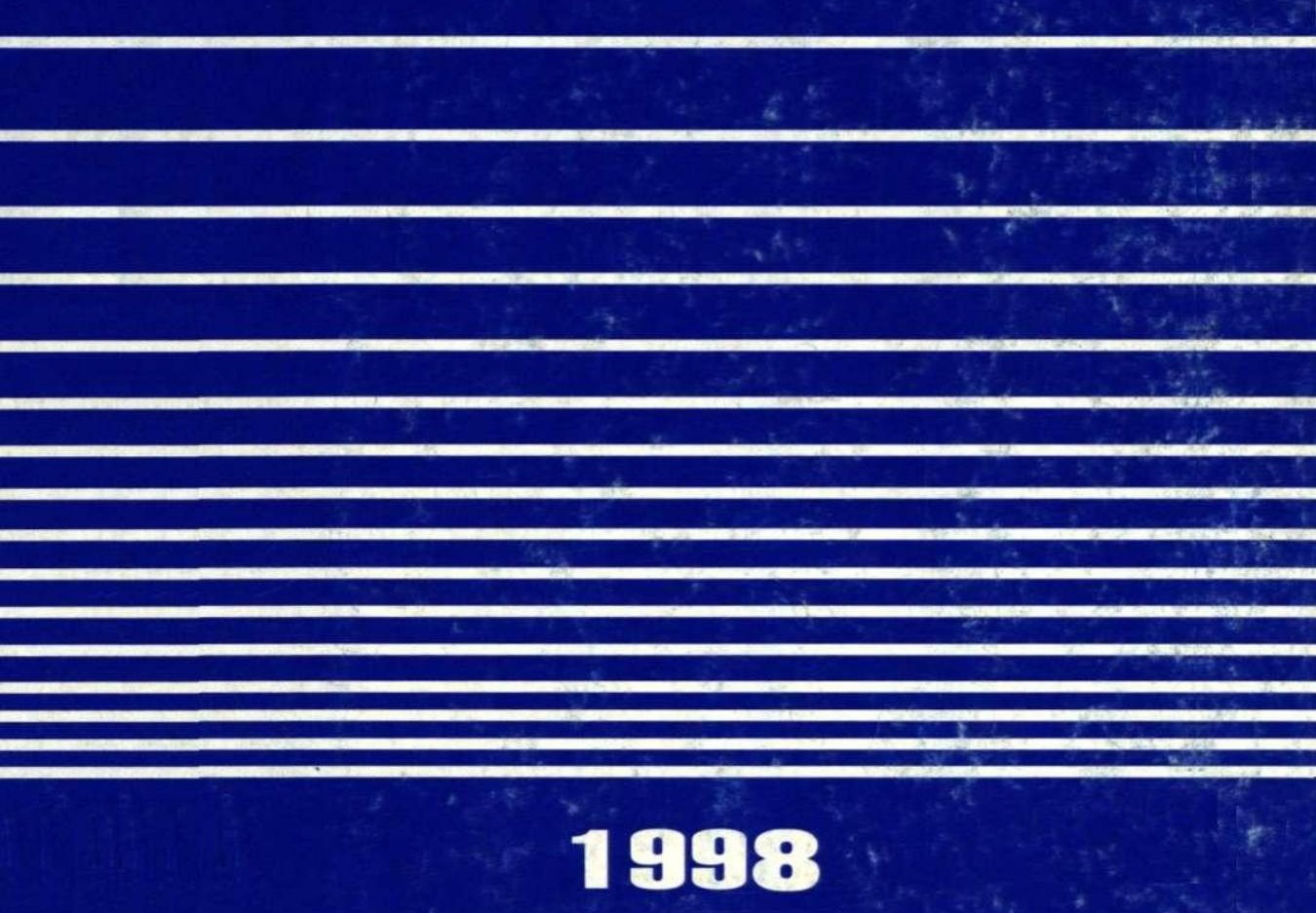




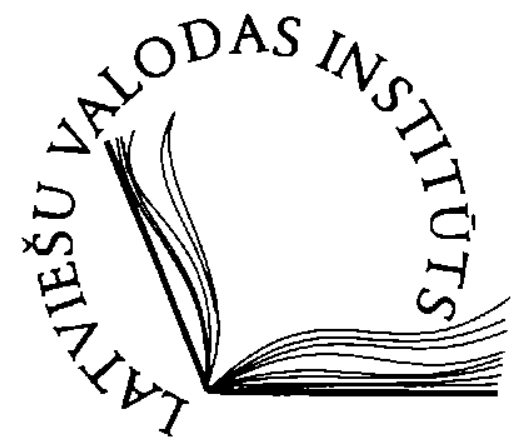

\section{LINGUISTICA}

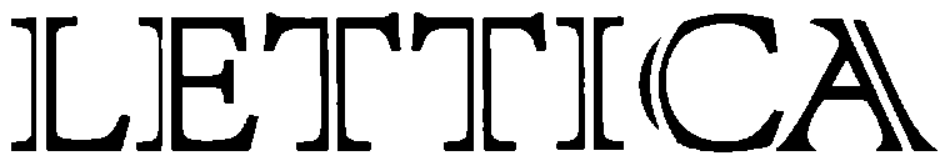

\section{LATVIEŠU VALODAS INSTITŪTA ŽURNĀLS}

1998

RİGA 


\title{
Dibinātājs \\ LU LATVIEŠU VALODAS INSTITŪTS \\ Registrācijas apliecība Nr. 000311118
}

\begin{abstract}
Redakcijas kolēgija
Aina BLINKENA, Ojārs BUŠS, Ina DRUVIETE, Ilga JANSONE, Jānis VALDMANIS, Andrejs BANKAVS (franču val. red.), Agris TIMUŠKA (vācu val. red.), Andrejs VEISBERGS (anglu val. red.)

\section{Korektore \\ Dorisa ŠNE}

Redakcijas adrese

Akadēmijas lauk. 1, 902. ist., Rīgā, LV-1050, tālr. 7227696, fakss 7227696, e-pasts <latv@lacis.lza.lv>

Mākslinieks

J.Rinķis

ISSN 14071932

(C) LU Latviešu valodas institūts, 1998 


\section{SATURA RĀDĪTĀJS}

Andrejs BANKAVS. Leksikogrāfija un arhaiskā leksika. 5

Andrejs VEISBERGS. False Friends in Latvian,

Dictionaries, Current Problems.

12

Ilga JANSONE. Varianti izlokšṇu vārdnīcās: problēmas

un risinājumi.

27

Elga KAGAINE. Vārdu cilmes norādes dialektālajās

vārdnīcās. . .

Agris TIMUŠKKA. Leksikogrāfiskas pārdomas par

dialektālās frazeolog̉ijas variabilitāti.

61

Brigita BUŠMANE. Izlokšņu tekstu fragmenti

"Latviešu valodas dialektu atlantā"

70

Benita LAUMANE. Brauc̄̄t un citi tautā lietotie

masāžas pañēmienu nosaukumi.

84

Anna STAFECKA. Verbi ar nozīmi 'rakt' un 'apbedīt' latviešu valodas izloksnēs.

100

Inese ĒDELMANE. Asociācijas latviešu valodas augu nosaukumos.

Māra ŠNEE. Par vistas nosaukumiem latviešu valodas izlokšṇu leksikā.

Sarmīte LAGZDIN̦A. Mūsdienu principu izmantošanas iespējas latviešu valodas vărdšķiru klasifikācijā.

Daina NITTNNA. Verbu pamatformas un verbu locī̌sana. Andra KALNAČA. Verba darāmās un ciešamās kārtas sinonīmija.

Juris GRIGORJEVS. Latviešu valodas patskaṇu akustisko ideālformu noteikšana.

Maija BRĒDE. Daži vērojumi par sonanta // variantiem latviešu valodā.

Genovaitè KAČIUŠKIENĖ. Akustinès dvibalsių

priegaidžiu ypatybès šiaurès panevèžiškių tarmèje:

instrumentinis tyrimas.

Daina NĪTIN̦A. Vārdu izvēles pragmatika.

Olga OZOLIN̦A. Daži sistēmas un normas mijiedarbības attīstības aspekti. 
Gunta LOČMELE. Latviešu reklāmas valodas attīstības tendences: informācijas kompresija.

Giedre ĊEPAITIENE். Kalbos etiketo situacijos ir poetinè funkcija.

leva ZAUBERGA. Feminisma ietekme uz mūsdienu tulkošanas teoriju un praksi.

233

GRÃMATU APSKATS.

Vajadzīga un noderīga grāmata. (J.Valdmanis).

244

IN MEMORIAM. Antoṇina Reḳēna. (B.Bušmane). 251

Juris Ripkis. (A.Blinkena)

256

HRONIKA.

Sesto reizi Vilñà. (I.Jansone)

257

Zinātnisk̄ā konference "Vārds un tā pētīšanas aspekti"

Liepājā (I.Ozola)

Valoda un tās elementi. (A.Timuška)

264

Artūra Ozola konference "Valodas vēsture un

dialektologija" 1998. gada 18. martā. (E.Kagaine)

270

Lingvistisko cilvēktiesību problemātika zinātnē un

politikā. (I.Druviete)

274

Baltisti tiekas Nevas krastos. (L.Balode)

280

Izloksnes: pētniecība un perspektiva. (A.Timuška) 283

Zinātniskā konference Rēzeknē. (A.Bankavs) 286

Risinot Eiropas valstu terminologijas problëmas.

(V.Skujina)

288

Kārtējā Baltijas studiju konference ASV (V.Skujina). $\quad 290$

Lituānistu ikgadējā konferencē. (L.Balode).

292

ZINAS PAR AUTORJEM. ... . .......... 


\section{Andrejs BANKAVS \\ LEKSIKOGRĀFIJA UN ARHAISKĀ LEKSIKA}

Leksika ir vismainīgākā valodas da|a, tā momentāni reag̀ $\bar{e}$ uz notiekošo sabiedrỉbā, radot vai aizgūstot jaunas leksiskas vieníbas jaunu jēdzienu izteikšanai. Bet cik tad bagāta vai nabaga ir valodas leksiskā sistēma? Neviena valoda nevēlas būt nabadziga, katrai ir savi leksiski semantiskie izteiksmes līdzekłi, kurus tā izmanto, lai varētu skaidri un daudzpusīgi formulēt domu. Un tomēr, ja gribam apzināt leksisko bagātỉbu, tad vispirms ir vēlme atsaukties uz leksikogrāfiskajiem avotiem. Bet vai tas būtu pietiekami? Neviens leksikogrāfiskais avots, kaut arī tas būtu visbagātākais tēzaurs, nav uzskatāms par pilnīgu vārdu registru. Teorētiski var piejaut domu, ka tikai mirušajām valodām ir iespējams sagatavot pilnīgu vārdu registru, bet darbs pat pie latīnu valodas tēzaura vēl nav pabeigts. Lingvistiskajā literatūrā sastopama atšķirīga informãcija par katras valodas leksisko vienỉbu skaitlisko sastāvu; tas ir diskutējams jautājums, jo katras valodas lietotājs vēlas redzēt savu valodu bagātu, krāšnu, niansētu un daudzveidīgu. Leksikogrāfiskie avoti dod tikai dalēju atbild̄i un, ja arī uzskatītu, ka K.Mîlenbaha un J.Endzelīna vârdnīca ir latviešu valodas tēzaurs, tā būtu tikai latvieša ausij patīkama metafora, jo skaidri zināms, ka tajā nav iekjauti daudzi aizguvumi, termini, bet, savukărt, tā ir bagāta ar leksiskajiem arhaismiem un dialektālo leksiku.

Ja pieñem, ka K.M̄̄lenbaha un J.Endzelīna vārdnīcā ieklauts ap 120000 leksisko vienību, bet Latviešu lirerārās valodas vārdnīcā, kura atspogulo mūsdienu latviešu valodas literāro leksiku, ir krietni pāri par 80000 vārdiem un vārdkopām, vai tad var uzskatît, ka tā ir valodas vārdu skaita robeža? Protams, ka nē, jo ne jau visi literārās valodas vārdi ir fiksēti šajās vārdnīcās, nemaz nerunājot par terminoloğiju, neliterārās valodas leksiku, okazionālismiem, vecvārdiem utt. Bet, ja lasăm, ka krievu valodas leksikā ir aptuveni 2 miljoni 
leksisko vienỉbu, bet franču valodā pat pāri par 5 miljoniem leksisko vienību, tad tas tikai rāda valodas leksiskās sistēmas loti aptuvenās robežas, uz kurām tiecas savā attīstības gaitā arī latviešu valoda.

Kā savā laikā pierādīja amerikāṇu valodnieks M.Svodešs, neskatoties uz leksikas straujo attīstību, tâs pamatfonds saglabā noteiktu pastāvību un stabilitāti $(79+2 \%$ 1000 gadu laikã). Bet par to, kā paplašinās to vārdu skaits, kuri nepieder pie pamatfonda, cik zināms, algoritms nav izstrādāts. Tiesa, atsevišķi pētījumi tiek veikti Francijã izdevniecībā LAROUSSE, kur jau kopš 1905. gada ik gadus izdod (izp̣emot, protams, kara laiku) viensējuma PETIT LAROUSSE, katru gadu to papildinot ar jauniem vārdiem, vārdu nozīmēm, kā arī svītrojot tos vārdus, kuri kḷuvuši neaktuāli. Reizi desmit gados vārdnīca tiek pārstrādāta pilnībā. Tas lauj leksikologiem sekot līdzi leksikas attīstībai pētīt, kādi leksikas slāṇi kJuvuši neaktuāli un pāriet pasīvajā leksikā. Kã liecina iepriekšējie pētijumi, PETIT LAROUSSE vărdnīcas jaunais izdevums ik gadus tiek papildināts ar apmēram 100 jaunvārdiem un 50 jaunām nozīmēm. Šāda dinamika pēc vienotas metodikas \auj pētît neologismu ienākšanu leksikā, kā arī vārdu novecošanās procesu gadsimta laikā.

Pie mums, diemžēl, leksikogrāfija attīstĩjusies loti lēni un nevienmērīgi. Ja līdz XX gs. sākumam tika publicētas tikai 22 tulkojošās vārdnīcas, tad šajā gadsimtā 5 reizes vairāk (vairāk nekā 110 tulkojošo vārdnīcu), no kurām viena trešã da]a pieskaitāmas pie aktīvajām vārdnīcām ar latviešu valodas leksiku kreisajā pusē (piemēram, latviešu ang|u, latviešu krievu, latviešu franču utt.). No tām visplašākā ir K.Mīlenbaha un J.Endzelīna Latviešu valodas värdnīca, kurai, kā zināms, otrs nosaukums ir Lettisch - deutsches Wörterbuch, un, kas ir latviešu lingvistikas lepnums un pastāvĩgs izziṇu avots valodniekiem. Tã bija arī pamatā pirmajai Latviešu - franču värdnīcai.

Neilgi pēc K.Mīlenbaha un J.Endzelīna 4. sējuma iznākšanas 1932. gadā LU Romāṇu filologiijas magistre 
J.Baltgalve kērās pie Latviešu - franču värdnicas sagatavošanas un 1937. gada pavasarī darbs pie jaunās vārdnīcas tika pabeigts un nodots rediğêšanai un papildināšanai prof. E.Blesem. Tikko pabeidzis darbu pie J.Langija 1685. gada Latviski vāciskãs vārdnicas (tā tika izdota 1936.g.), E.Blese lēnām un ar pārtraukumiem ḳērās pie grūtā rediǵēšanas darba, jo uz vina rakstāmgalda jau gaidīja citi steidzamāki darbi, piemēram, Pareizrakstības vārdnicas manuskripts (iznāca 1939. g. 263 lpp. apjomā) un pētījums Valoda un tautas gars (izdots 1940. g. 245 lpp. apjomā). Pienāca 1940. gada trauksmainais jūnijs. Trešā da|a izrediǵgètās vārdnīcas (apmēram 20 loksnes) jau bija iespiesta, pārējā da|a tika steigā papildināta ar jauno padomju reāliju atveidi, par pamatu ṇemot 1939. gadā izdotās prof. L..Ščerbas lielās Krievu franču vārdnīcas datus. Latviešu franču vārdnìca iznāca pēc pusgada - 1941. gada sākumā 3100 eksemplāru lielā metienā un faktiski tā bija pirmā padomju laikā izdotā vārdnīca (1). Neliela formāta 875 lappusēs bija iek/auts vairāk nekā 26000 šḳirk|a vārdu, kuri daudzējādā ziṇã atspogujoja latviešu valodas 20. un 30.-to gadu leksiku, kas fiksēta K.Mīlenbaha un J.Endzelīna vārdnīcas sējumos.

Kaut gan šobrīd no vārdnīcas sagatavošanas - brīža pagãjuši 60 gadi, tā piesaista uzmanību ar lielu skaitu vārdu, kuri latviešu literārajā valodā vairs nepastāv, tiek lietoti ar atškirīigu gramatisko formu vai ar citu nozīmi.

Arhaiskā leksika pirmajā Latviešu franču vārdnīcā netiek speciāli apzīmēta, tā jaušama tikai pēc vārdnīcas lietotāja lingvistiskăs izjūtas, to salīdzinot ar citu vārdnīcu dotumiem un norādēm vai arĩ ar franču valodas atbilstošo vărdu.

Šajā vārdnīcā pārsteidz lielais vārdu variantu skaits viena šḳirkla ietvaros. Tas var variēties no 2 - 5, piemēram,

ar diviem variantiem (oläjs, oliens; norēķins, nolēsums; krāskuris, krāsnkuris; priekšcēliens, priekšnesums);

ar trim variantiem (sprogis, sproggalvis, sprogainis; snāte, snātene, snātne; stadala, stadals, staduls; krimelde, krimilde, krimulda; ozoläjs, ozoliens, ozolaine); 
nogülums);

ar četriem variantiem (nogula, nogulda, nogulums,

- ar pieciem variantiem (priedaine, priediena, priediene, priedājs, priedulājs).

Ja salīdzinām pirmajā Latviešu franču vārdnīca iekJautos vārdus ar mūsdienu latviešu valodas vārdiem, tad, neskatoties uz loti îso laika atstarpi, t.i. 60 gadiem, varam secināt, ka notikušas lielas izmainas gan leksēmu morfologiskajā, gan semantiskajā raksturojumā.

Morfoloǵijā vērojamas šădas atšksirības:

1) dzimtes kategorijas maiṇa (galvenokārt vīriešu dzimtes lietvārdiem pārejot sieviešu dzimtē):

apetits - apetīte (sal. fr. appétit m),

karnizs - karnize (sal. fr. corniche f; vācu Karnies n; krievu карниз),

korsets - korsete (sal. fr. corset m),

sadars - sadare,

bet atspulga atspulgs;

2) atsevišķiem lietvārdiem notikušas izmaiṇas vārda saknē:

attaka - atteka,

rìlis - rìma;

3) samērā bieži vērojama priedēkju maiṇa:

izslaukas - saslaukas,

izdusa - aizdusa,

atgarša - piegarša (arĩ atgarža),

aptvars - ietvars,

pamisēties - samisēties,

atkalpot - nokalpot,

atmaukt - nomaukt, novilkt (cimdus, zeḳes),

atroce-aproce (bet atrocīt),

nokāje - piekāje,

nolēse - aplēse;

4) bezpriedēk|u vārda vietā tiek lietots vārds ar priedēkli un otrâdi:

pasēja - sēja. 
izdusa - dusa (iet uz dusu),
gaumēt - iegaumēt,
sauka - iesauka;

5) bezpiedēkla vārda vietā tiek lietots vārds ar piedēkli:

caure - caurule,

atspìda - atspīdums;

6) atsevišḳiem lietvārdiem mainījies skaitlis:

nieva-nievas;

7) vārdi, kuri mūsdienās tiek lietoti analītiskā formā, vārdnīicā doti sintētiskā formā:

grāyjot - rakı grāvjus,

grìdot likt grìdu.

Semantikā atzīmējamas šādas īpatnības:

1) virkne vārdu izgājuši no latviešu valodas akt̄̄vās leksikas:

aceknis ( = cepure) - bonnet,

adatnīca (= adatu kārbiṇa) - étui à aiguilles,

aizsēklis (= sēkla nākamajam gadam) - semailles pour l'année prochaine.

Îpašu grupu veido salikteṇi ar antonīmisko paradigmu ar maz- pretstatā liel-. Tā vēl tagad lieto vārdus lielcelı̆, lielsaimnieks, liellops u.c., bet vairs nav apritē mazcels̆, mazsaimnieks, mazlops utt.

2) svešvārdi, kuri vairs netiek lietoti un pieskaitămi pie arhaismiem, t.i., vārdiem, kuri apzīmē jēdzienus, kas pastāv vēl mūsdienās, bet tiek apzīmēti ar citu värdu:

fantoms (= rēgs) - fantôme,

firniss $(=$ laka $)$-vernis,

ekspedēt (= aizsūtīt) - expédier,

flaga (= karodzin̄s $)$ - pavillion,

telefonēt (= piezvanit, zvanīt pa telefonu)-téléphoner;

3) svešvārdi, kuri pieskaitāmi pie historismiem, vārdiem, kuri apzīmē jēdzienus, kas zaudējuši savu aktualitāti mūsdienās:

furā̌za (= lopbarība) - fourrage;

4) vārdi, kuri mūsdienās pieskaitāmi pie dialektālās leksikas:

grezele (= slēgts grozs) - panier couvert, 
pirkstele $(=\mathrm{dzirkstele})$ - étincelle,

plunces, plunči (= plaušas) - poumons,

birda (=smalks lietus) - pluie fine.

naǵe (=varde) - grenouille.

kaupinš (= krupis) - crapaud.

5) vārdi, kuri mūsdienās pieskaitāmi pie sarunvalodas leksikas:

izmozèt (= izāzēt; izsmiet kādu) - se moquer,

grabis (= plāpa) - bavard,

blauka (=b|āvējs) - criard;

6) vārdi, kuri neieviesās latviešu valodā, t.s. potenciālismi:

ausa (= rìtausma) - aube du jour,

ätrulis (= karstgalvis) - tête chaude,

bédulis (= nelaimigais) - malheureux;

mauceknis, mauceklis, mauklis (= gredzens bez akmeņiem) jonc,

mäkulis (= lietpratējs, eksperts) - connaisseur, expert,

kniebeklis (= knaibles) - pince,

rasme, rasma (= veiksme) - profit.

Nobeigumā gribētos atzīmēt, ka pirmā Latviešu - franču vārdnīca ir labs faktiskais materiāls lingvistiskām studijām. Daudzējādā ziṇā balstīta uz K.Mīlenbaha un J.Endzelīna vārdnīcu, Latviešu - franču vārdnicca koncentrētā veidā dod bagātīgu vielu latviešu valodas leksikas pētījumiem. Tā varētu pat tikt nosacīti uzskatīta par vienīgo Latviešu - franču valodas dialektālās leksikas vārdnīcu, jo nākošajā Latviešu-franču vārdnìcā (2), kas iznăca gandrīz 30 gadus vēlāk (1970. gadā), daudz vairāk vietas bija atvēlēts nevis dialektālajai un vēsturiskajai leksikai, bet gan internacionālajai leksikai.

\section{ATSAUCES}

1. Baltgalve J. Latviski-franciska vârdnīca / Red. un papild. E.Blese. R., 1941, - LXXX + 875 lpp.

2. Bojāte A., Pizova F., Zandreitere I. Latviešu - franču vărdnīca/ I.Niseloviča red. Ap 26000 vārdu. - R., 1970, - 900 Ipp. 


\section{LEXICOGRAPHIE ET LEXIQUE ARCHAÏQUE} Résumé

Dans toute langue, on a constaté le caractère instable du lexique et cette instabilité se lit clairement, si l'on compare les entrées et les disparitions de ces éléments lexicaux dans des dictionnaires du même type, écrits suivant les mêmes normes, mais à des dates différentes (cf. le Petit Larousse périodiquement révisé).

Une analyse attentive de premier dictionnaire letton français (édité à Riga en 1941) montre que la base lexicale utilisée alors venait du grand dictionnaire de Mülenbach Endzelin (Lettisch-deutsches Wörterbuch en quatre volumes publié entre 1929 et 1932). Ce dictionnaire letton-français contenait un grand nombre de mots archaïques, de variantes lexicales, notamment en ce qui concerne le genre des substantifs ou la signification des préfixes. Or au cours de ces six dernières décennies la disparition de nombreux lexèmes d'origine dialectale ou étrangère, par suite de non-utilisation, n'a en fait seul caractère d'appauvrissement, mais correspond au contraire au dynamisme d'un système lexical toujours à la recherche d'un vocabulaire mieux compris de tous, et mieux adapté aux besoins de communication de notre époque. 


\section{Andrejs VEISBERGS \\ FALSE FRIENDS IN LATVIAN, DICTIONARIES, CURRENT PROBLEMS}

Contrastive analysis of both related and not related languages presents a large corpus of similar or identical lexemes - words similar in spelling, pronunciation and often in meaning. Even in many non-related languages this phenomenon would reach the proportion of 10 to $20 \%$. It is much higher in terminological corpora where there is a high percentage of international (Neoclassical) words. A considerable share of these lexemes are false friends (FFs). The higher the number of loans in a language the higher the possibility of FFs. The more exposed a language has been to language contacts, especially with intermediary languages, the more false friends one can expect. Latvian, with its two main contact languages - German and Russian - serving as intermediary languages for distant and indirect contacts with other international languages - English, French, Latin and Greek - serves as an excellent sample of FFs studies.

In order to demonstrate that the problem is of growing importance the following extracts from a recent translation follows:

Bija skaidrs, ka viņš nedomā sākt akciju pret nacistiem tülìt...

Vervējot savam slepenajam dienestam vīrus, vin̄s tos uzmanigi izvēlèjās no vācu rezerves virsniekiem un inteligences.

Vãcija bija spiesta sūtīt brīvprātĭgos uz Baltijas valstīm un Somiju, lai mèginātu iedabūt sarkano ǵēniju pudelē, no kurienes tas škita izplešamies pa visu Eiropu.

...dzelzcela darbinieki san̄èma pavēli koncentrēt ripojošo materiälu.

(I. Kolvins. Kanāriss. Rīga: Junda, 1993.) 
False friends are word pairs that have similar spelling and pronunciation but different meaning. The word pairs are generally of common etymology. The similarity leads to false associations, wrong use or misunderstanding, or in the best case distortion of context, imprecision, disregard for the right stylistic colouring. Language material, coupled with actual use, shows that the FFs can be divided into several types:

1. false friends proper;

2. occasional or accidental false friends;

3. pseudo false friends.

False friends proper.

1. Complete (absolute) false friends - pairs of words in the respective languages which are monosemantic in both or one language and this meaning differs from that of its counterpart, e.g.

English: intelligence (izlūkošana) inteliğence (intelligentsia); band (orkestris) banda (gang); preservative (konservants) :: prezervatīvs (condom); kartons (cardboard) :: carton (tetrapaka);

French: journal (ikdienas laikraksts) ̌̌urnāls (revue, magazine); atelier (mākslinieku darbnīca) ateljē (haute couture);

German: Galanterie (galantums) galantērija (Galanterieartikel); Rotte (pūlis, banda) :: rota (Kompanie); taksometrs (Taxi) :: Taxameter (skaitītājs), kotlete (Beulette) :: Kotelett (karbonāde).

2. Partial False friends - pairs of words in the respective languages where the Language One word is more polysemantic than Language Tworword, i.e. where some meanings coincide while some others do not. Here the situation is more subtle, the possible "trap" - more hidden.

English: džins gin, genie (ğēnijs), etiķete :: etiquette, label (uzlīme); 
French: jaquette žakete, apvalks; naktskrekls (Canadianism);

German: Ball bumba, balle; Bank sols, banka, Bande banda, mala, Mutter māte (sar. mutere), uzgrieznis.

3. Nuance differentiated word pairs basically have the same denotative meaning, yet have slight semantic, usually connotative differences. The difference can have a variety of reasons and features:

- semantic limits - the word in one language has a more general meaning than in the other, for example, the word is used as a term in one language while belongs to the general stock in another;

- register (stylistic) differences the difference between literary, neutral and colloquial type of the words French, German chance :: šanse (sar.);

- general attitudinal characteristics the word may have, for example, negative connotation. Words can have different usual contexts of usage or certain contextual limits can be imposed in different languages French negre négeris;

- there can be a difference in frequency of use, English: akvarelists :: aquarellist (water colour painter), demisija :: demission (resignation);

- collocation limitations - in one language the word is lexically less free, or words may not share the same syntactic structures;

- diachronic digression - the word in one language is more archaic than in the other - this leads to the words having restricted usage sphere, when one cognate has become more archaic or even obsolete while the homonym can be used in modern speech velosipēds German Velociped (dated and dialectal), Fahrrad; Latvian - French velosipēds :: velocipede (dated), velo, bicyclette. 

features.

There can be a combination of the above mentioned

Occasional or accidental false friends - word pairs that are similar by almost pure coincidence, not by common etymology - these are non-cognate interlingual analogues. They lack the etymological link and normally belong to a different logico-subject group which usually helps differentiate them, e.g. bite (bee) :: bite (kodiens), ogle (coal) ogle (mïlas pilns skatiens), pile (drop) :: pile (kaudze), skate (show) skate (slida). There are other factors that help differentiation and make mistaken understanding rare:

some of them belong to various parts of speech mute (mēms) :: mute (mouth), ass (sharp) :: ass (ēzelis),

some have singular versus plural form stars (zvaigznes) stars (ray), pants (couplet) :: pants (bikses), elks (idol) :: elks (alni),

some are proper names versus common nouns (Ogre (town in Latvia) :: ogre (briesmonis).

And finally these word pairs stand isolated only in dictionaries, while context usually helps avoid misunderstanding, acts as a life saver. Occasional FFs are normally not included in dictionaries, however separate ones might be considered for it. Examples of occasional FFs in other languages:

French pirogue (piroga) :: pīrăgs (pate), talon (papēdis) :: talons (ticquet), gars (puisis) :: gars (esprit).

German Gott (dievs) :: gots (Gote), bass (barfuss) :: Bass (loti, bass (mūz)).

And thirdly, there are also actually non-existent word pairs which are rarely discussed. Let's call them Pseudo false friends. The language learner builds a nonexistent word on the basis of the native word, usually believing that the native word must have a corresponding identical foreign word. Though theoretically hypothetical, any teacher will have met these in the 
speech of the students. The pseudo friend is usually created on the basis of false analogy, belief that the lexeme (usually international) must have the same use in the other language. For example, there is no blocade in French while Latvian bloksade (a loan from German die Blockade), being similar to many loans from French kanonāde (canonnade), glisāde (glissade), traditionally leads to the pseudo friend use for Latvian learners of French. Neoclassical root compounds often differ in other languages, e.g. Latvian lexemes autostrāde, automagistrāale often lead to pseudo friend coinage in English (correct motorway, though Italian loan in English autostrada) or German (correct Autobahn). Also Latvian narkomanns leads to creation of narcoman (drug addict), the association being that the shortened affix of mãns is the loan from English man. Similar: alpinisms - alpinism (mountaineering though there is alpinist), psihiska slimība - psychic disease (mental illness), aviotehnika aviotechnics (aerotechnics). German vitrāža Vitrage (Glasgemälde).

An experiment carried out with advanced Latvian students, who were given a specially designed native language text and instructed to supply the English translation, but were not informed about the problem, (they were actually told to pay special attention to grammar) actually showed that in $60 \%$ of the likely cases there were pseudo friends created.

And finally one should always remember that language is in a state of flux thus changes within the corpus of FFs are possible, indeed, they are always there. Separate FFs pairs may cease to be such because the meaning of the word undergoes a change or a new meaning is developed. At specific periods of time, when there is a great language shift, this phenomenon can take an overwhelming effect. Latvian at present undergoes such a change (similar to many East and Central European countries, formerly in the Soviet block). Reorientation towards the westem world means reorientation towards western languages (English, German, French). Many of the FFs were the result of Russian 
serving as the intermediary language, and now, with direct contacts, say, between the above mentioned languages and English, scores of former FFs within a very short period are more and more becoming "real friends" (Veisbergs, 1996: 633).

This presents serious problems for linguists and dictionary compilers in deciding whether to accept such changes and list them in dictionaries or not. The traditional approach would claim that here is an instance of massive and deplorable foreign interference into the established semantic system of the language. The descriptive approach, supplemented by computer gathered corpus, however, would suggest a change in the reality -- a semantic change is taking place and a particular pair of false friends may-cease to exist. What remains to be done is maybe in some cases fight the tendency, e.g. biljons (miljards), dekāde (desmitgade), prēmija (apdrošināšanas iemaksa), or agree with it and list the new meaning of the word, e.g. ambulance (ātrās palīdzības mašina), studija (iestāde), aktivitātes (darbība), kapacităte (spējas, joma), dabas konservācija (saglabāšana), romance (mīlestība), konspirācija (sazvērestība), divīzija (liga), etc.

Darbs, bērni un romance mobilo telefonu laikmetā vienas stresainas dienas laikā. (Piektdiena, 27.7.1997.)

Dänijā tas ir Joti neparasti, ja autoritātes iejaucas gimenes lietās. (Diena, 16.5.1997)

Rüpnìcas celtniecỉba izmaksäja Volkswagen 2,5 biljonus marku. (Dienas Bizness, 12.3.1993.)

Igauni "arestêti", bet paši Vācijā nepadosimies. (Rīgas Balss, 1.4.1996.)

Tam nepieciešamas šădas īpašibas: kapacitāte savos pētījumos...(Universitätes Avīze, 28.4.1998.)

This is the result of intrusion of Anglo-American elements - an influx which is actually enhanced because of the current political situation. Here again the compiler has to balance between the old dilemma and reckon the risk of being lost in the 
flux of time. Thus false friends lists and dictionaries need regular updating. This refers in particular to languages the speakers of which belong to communities that are undergoing all-embracing transformations.

\section{False friends dictionaries}

Dictionaries of false friends, called also false cognates, faux amis, deceptive doubles, paronyms reflect a sphere of linguistics where problems of translation, leaming and contrastive semantic studies interface.

It must be said that after a relatively long period of emphasis on grammatical patterns and structuralism, contrastive linguistics again addresses problems of lexicology, however, with a more semantic emphasis. Yet lexicography, particularly bilingual lexicography was the branch that maintained the contrastive studies within lexicology and the revival of interest seems to be caused mainly by learning problems in lexis. False friends (FFs) studies have always been more or less successfully exploited in practical teaching (Bankavs, 1989; Topalova, 1996) and now with attempts of setting up parallel databases, FFs are being integrated into tools for the learner (Nicholls, 1995).

Dictionaries of false friends (FFs) is a sphere of bilingual lexicography mainly addressing the needs of translators (interpreters) and language learners. The different audience determines the necessity to consider specific groups of language users. This is necessary if dictionaries are to be user-friendly as the target groups need specific form of presentation. Learners' and translators' expectations of the dictionaries will be considered.

What we observe in the world of dictionaries is a steady growth in variety of the FFs dictionaries - learner's manuals, multilanguage dictionaries, mixed variants. It also makes me question whether the FFs dictionaries are to be viewed solely as learner's dictionaries, as they are defined by Gorbahn-Orme 
(1991: 2883). I suppose the difference of scope entails also different content, different presentation and different user. Of course, broadly speaking any dictionary can be viewed as a tool for learning, but specifically tailored FFs learner's dictionaries suggest that the other extensive FFs dictionaries are closer to the informative, specialist type, e.g. Hill's dictionary on FFs in 15 languages (Hill, 1982). Shall we consider it a leamer's dictionary? Maybe it is better to say that what we deal with a new genre and within this new genre we see a great variety of dictionaries and the more or less sophisticated ones are closer to the informative, specialist type (Jackson, 1988:165). I presume the target audience can and must determine what and how is included in a FFs dictionary for as we see there can be quite a difference between the types of FFs and their treatment. Pseudo friends are normally not represented in dictionaries. In theory their number could be dramatically high, in practice it is rather limited. There is also a tendency to include FFs in some general bilingual dictionaries.

Of the multitude of specialized FFs dictionaries in different languages there seem to be four general types:

1. The basic or primitive FFs dictionary (Muravyev, 1969; Hill, 1982) which aims at drawing the user's attention to the diversity of meaning of the formally similar word pairs, offering, however, no explanation. The shortcoming of this dictionary type is that it can practically be used only in conjunction with another dictionary, as it offers neither explanation of the FFs meaning in the Language Two, nor the correct variant for Language One word. Thus the only function of this dictionary is that of awareness raising (informing the reader of the of the danger). This sort of dictionary normally covers only the subtype of complete false friends proper.

2. More expanded FFs dictionary (Browne, 1987; Labarre, 1989; Schwarz, 1993; Parker, 1992; Veisbergs, 1994) which gives at least the main meanings of both FFs thus offering the users the possibility of judging for themselves the real difference 
in meanings and providing the correct variant. Some of these dictionaries also offer examples or / and translations of limited scope (Sane, 1992; Prado, 1993;Vanderperren, 1994).

3. A detailed FFs dictionary (Akulenko 1969; Gottlieb 1972; Dictionnaire, 1979; Thody, 1985) going into in-depth analysis of the word pairs, often presenting excerpts from original texts, translations, covering all meanings of the entries, sometimes pointing out examples of wrong use. An academic dictionary of this type has a certainly smaller number of users as neither learners nor most of the advanced users would have time, interest or ability to read the lengthy semantic analysis. Yet linguists or perfectionist users and translators may find this sophisticated approach of interest. Dictionaries of this type often present also confusible words and rather far-fetched cases.

4. Learner's dictionary of FFs (Breitkreuz, 1991, 1992) concentrates on the most typical and frequent FFs pairs, analyzing them and supplying a variety of exercises aimed at recognition and training of the right use. They tend to be typically tailored, often the words are not treated in alphabetic order - the learner's dictionary may sometimes be more like a textbook (Dretzke, 1990).

These dictionary types do not always appear in so clear-cut a form - more and more dictionaries tend to add the exercise part as appendices, there are different mixed cases.

It is evident that making a dictionary user-friendly in all cases means including apart from the word pairs also their meanings, thus providing the user with something more than a scant warning. Absence of the correct variant is as confusing for the learner as dull for the advanced reader. Thus more expanded dictionary Type 2 is certainly preferable to the basic dictionary of Type 1. Avoiding the necessity of cross-references in other dictionaries is an obligatory condition for several reasons:

- There may be FFs mistakes in the general bilingual dictionaries. 
- Semantic explanations in monolingual as well as bilingual dictionaries are not always sufficient for judging the meaning details - it especially refers to the nuance differentiated FFs meanings.

- Sending the users for another dictionary is wasting their time and unethical.

On the other hand, the analysis of FFs dictionaries shows also a very broad approach - often diverse linguistic phenomena are included (diachronically diverging words of common etymology, synchronically accidental words of common spelling and $/$ or sound, just similar words). Thus, for example, Birbrajer's (1987) dictionary deals with false friends, words "which might share several meanings (friends) but differ with regard to at least one meaning", also words that "may seem identical but are not and in such instances there is a stylistic or frequentative difference", etc. It is dealing with too many lexical groups at once and is neither effective nor useful. This often borders on the so called confusible words enhanced by the arrival of new confusible word dictionaries, sometimes called also tricky word dictionaries (Williams, 1993; Carpenter, 1993). These are as a rule monolingual (partly aimed at a native speaker) and pronunciation seems to play great role in determining what to include. It seems that inclusion of confusibles in a FFs dictionary should be carefully weighed and implemented on individual basis only.

As two rather different groups of people - learners and advanced users - seem to take interest in these dictionaries, a more specific readership targeting could be expected, along the broad lines of these two groups.

\section{a. Translator - Advanced User}

Noncognate interlanguage analogues (accidental FFs) and pseudo friends are usually of little interest for a mature bilingual speaker which the translator is presumed to be. Translators (less so interpreters) rarely confuse the complete FFs these are 
generally the trap for the beginner learners. Partial FFs, with broader and more polysemantic meaning in one of the languages, are more likely to present difficulties for the translator. Perhaps the most important type for the advanced user is the nuance differentiated word pairs that basically have the same denotative meaning, yet, have connotative differences (semantic limits, stylistic colouring, collocation limitations, diachronic digression). Thus only two groups are of practical interest for the translator and these would deserve well thought-over though concise treatment.

A poll conducted by the author among translators and MA students of Translation and Interpreting suggests that they prefer the simple 2 dictionary, while the detailed dictionary was judged too sophisticated and time consuming. If even these professionals considered dictionaries of this type too hard to handle, they can be viewed as interesting research studies but not tools for professional performance.

The subgroup analysis in different translations (mistake hunting) suggested that partial friends are the real problem for translators and should be in the centre of attention of dictionaries.

This does not mean that absolute FFs have to be excluded from the advanced users' dictionaries. They have their rightful place there, but, being simpler, should command neither most attention nor most space.

\section{b. Learner - the Beginner}

The learner interest seems to lie mostly in the sphere of FFs proper, partial false friends and occasional pseudo friends, plus, perhaps, some regularly mistaken confusibles (e.g. genius, genie, gin). Pseudo-homonymy presents a serious problem for dictionary compilation as theoretically one can create an unlimited number of false association pairs, thus increasing the scope of corpora considerably. Here teachers' experience is of importance and could help elucidate words that really occur in 
the speech of the leamers. One can also set out the risk groups where there is a bigger chance of pseudo friend occurrence. These are usually compounds, one element of which is present in both languages, e.g. having portrait and portrets in English and Latvian leads to creating the pseudo friend autoportrait for Latvian autoportrets instead of self-portrait.

As we see not only FFs themselves as a category undergo a change but also their depiction in dictionaries is changing. As can be seen there is only one dictionary of FFs in Latvian naturally representing one type of dictionaries and only one language pair. Thus this is a sphere where much could be done and achieved in the coming years taking into account the current changes in language.

\section{REFERENCES}

Akulenko V (1969) Anglo-russkiy i russko- angliyskiy slovar' "lozhnih druzei" perevodchika. Moskva, Sov. Enciklopediya. Bankavs A. (1989) Les fawx-amis du traducteur franco-lettons. Rīga, LVU.

Birbrajer J. (1987) Friends and False Friends: a dictionary of "false friends" between Polish and Russian with an English translation of all entries. Stockholm, Almquist and Wiksell International.

Breitkreuz H. (1991) False Friends. Rowohlt.

Breitkreuz H. (1992) More False Friends. Rowohlt.

Browne V (1987) Odd Pairs and False Friends. Bologna, Zanichelli.

Carpenter E. (1993) Confusable Words. Collins, Cobuild.

Dictionnaire pratique des fawx freres. (1979) Pluriguides Nathan.

Dretzke B., Nester M.I. (1990) Student's Guide to False Friends, New Friends and Old Friends. Berlin, Cornelsen Verlag. 
Gorbahn-Orme A., Hausmann F.J. (1991) "The Dictionary of False Friends", in Wörterbücher. Dictionaries. Dictionnaires. Vol. 3. Berlin and New York, Walter de Gruyter, pp. 2882-2888. Gottlieb K.H.M. (1972) Deutsch-Russisches und RussischDeutsches Wörterbuch "der Falschen Freunde des Übersetzers" Moskau, Sowjetskaja Enziklopedija.

Hill R.J. (1982) A Dictionary of False Friends. London.

Jackson H. (1988) Words and Their Meaning. London-New York, Longman.

Labarre/Bossuyt (1989) Cut that Chat. Faux amis et mot perfides anglais-francais. Bruxelles, De Boeck.

Muravyev V. (1969) Faux amis. Moscow, Prosveshcheniye.

Nicholls D. (1995) "Digging deeper into false friends", in: The Cambridge Language Reference News Number 1, pp. 6-7.

Parker G., Cornell A. (1992) NTC's Dictionary of False Cognates. Lincolnwood, NTC.

Prado M. (1993) NTC's Dictionary of Spanish False Cognates. Lincolnwood, NTC.

Sane S., Schepisi G. (1992) Falsos amigos al acecho. Bologna, Zanichelli.

Schwarz H. (1993) False friends: Lumske ligheder Danskengelsk. Frederiksberg, Samfundslitteratur.

Thody Ph., Evans H. (1985) Faux amis and Key Words. London, Athlone Press.

Topalova A. (1996) "False Friends" in Translation Work: an Empirical Study. In: Perspectives: Studies in translatology. 4:2, Copenhagen. pp. 215-222.

Vanderperren Fr. (1994) Dictionnaire faux amis allemandfrancais. Duculot.

Veisbergs A. (1994) English-Latvian, Latvian-English Dictionary of False Friends. Rīga, SI.

Veisbergs A. False Friends Dictionaries: A Tool for Translators or Learners or Both. In: Euralex '96 Proceedings. Vol. 2. Göteborg: Göteborg University, 1996. pp.627-634. 
Williams D. K. (1993) NTC's Dictionary of Easily Confused Words. Illinois, NTC.

\section{VILTUS DRAUGI LATVIEŠU VALODĀ, PROBLĒMAS UN ATSPOGULOJUMS VĀRDNİCĀ Kopsavilkums}

Viens no valodu kontrastīvās analīzes praktiskākajiem aspektiem ir t.s. tulkotāju viltus draugu (VD) izpēte. PakJaujot gan radniecigu, gan neradniecīgu valodas materiālu kontrastīvajai analīzei, iegūstam lielu līdzīgu vai identu leksēmu skaitu attiecīgajā valodu pārī. Zināmu dału šai kopā veido VD, kuru analize ir svariga gan no tulkošanas, gan apmācỉbas viedokla. Jo valodas tuvākas, jo vairāk tās saistītas ar vēsturiskajām saitēm, jo vairāk šādu vārdu pāru. Latviešu valodā aizgūšana ar tās divu vēsturisko kontaktvalodu (vācu un krievu) palīdzîbu ir palielinājusi nozīmju maiṇas iespējas.

Viltus draugi ir vārdu pāri ar līdzīgu rakstību un .izrunu, bet dažādu nozīmi. Praktiski gandrīz visos gadījumos VD vieno etimologiskas saiknes. Iž̌ķirami trīs VD paveidi: îstie viltus draugi, gadijuma viltus draugi, viltus pseidodraugi.

Savukārt starp îstajiem viltus draugiem izškiram:

1. absolūtos VD, kad starp abiem vārdiem nav nozīmju sakritības, piemēram, intelligence (izlūkošana) inteligience (intelligentsia);

2. dạējos VD, kad vienā no valodām vārdam ir vairākas nozīmes, no kurām viena sakrīt ar otras valodas vārda nozīmi, piemēram, etiķete etiquette (uzvedības normas), label (uzlīme);

3. niansēs atšķirīgos VD, kad starp līdzīgajiem vārdiem ir vērā ṇemamas semantiskas atšķirības, stila, reǵionālas, konotatīvas, biežuma, diahroniskas, valences vai citas atšḳirỉbas.

Gadijjuma viltus draugu līdzỉbai ir gadījuma raksturs, nevis etimologiiska izcelsme. To sajaukšanas iespējas ierobežo pilnīgi atšḳirīgā semantika, piederỉba dažādām vãrdu šḳirām un citi 
momenti, piemēram, bite (bee) :: bite ( kodiens), Ogre :: ogre (briesmonis).

Pseidodraugi ir faktiski neeksistējoši vārdu pāri, kad svešvalodas lietotājs darina tajā neeksistējošu vārdu pēc dzimtās valodas principiem parasti internacionālus salikteṇus: autoportrets autoportrait (nevis pareizais self portrait), aviotehnika aviotechnics (nevis aerotechnics), psihiska slimība :: psychic disease (nevis mental illness).

Jāatceras, ka valodā notiek nepārtrauktas izmaiñas, kas ietekmē arī VD sfêru. Tā deviñdesmitajos gados latviešu valodas pārorientācija no krievu valodas uz anglu valodas modeliem (sevišḳi terminologiskajā sfèrā) kopā ar ievērojami pieaugošo interferenci noved pie ievērojamām pārbīdēm VD sfērā, kad bijušie viltus draugi iegūst otras valodas nozīmi, piemēram, ambulance, romance, divizija, konspirācija, aktivitătes.

Pastāv vairāki VD vārdnīcu tipi, sākot no tādām, kas satur tikai VD uzskaitījumu, un beidzot ar tām, kas detalizèti apraksta visas vārdu nozīmes, to atškiriribas, ilustrē VD ar piemēriem un citātiem no literatūras utt. Vērojama dažādu vārdnīcu tipu pārklāšanās un dažāda attieksme pret VD paveidiem. Autors ierosina šksirt vārdnīcas, kas domātas valodas apguvējiem, no tām, kas domātas tulkiem. Atšķirigas mērḳgrupas savukārt nosaka atšķirīgu pieeju materiālu atlasei. Tulkiem un valodas speciālistiem domātajās vārdnīcās nevajadzētu dot gadījuma VD, savukārt valodas apguvējiem paredzētajās vārdnīcās vajadzētu iek|aut tieši raksturīgās valodas kłūdas, neskatoties uz to logiskumu / nelogiskumu, izcelsmi vai sadalījumu. 


\section{Ilga JANSONE}

\section{VARIANTI IZLOKŜNU VĀRDNĪCĀS: PROBLÊMAS UN RISINĀJUMI}

Dialektālajā leksikogrāfijā, kas balstās uz mutvārdu komunikācijā iegūtu valodas materiālu, var runāt par divu veidu variantiem:

1) par gramatiskajiem variantiem, kad variējas vārda fonētiskais, t.sk., intonatīvais, un/vai morfologiskais skanējums;

2) par nominācijas (< lat. nominatio 'nosaukšana') vai sinonīmiskiem variantiem, kad vienai reālijai vai parădībai (arī darbỉbai, norisei) ir dažādi (ne gramatiski, bet leksiski) nosaukumi.

Variants leksikogrāfijā - teorētiski maz vai tikpat kā nemaz nepētīta problēma, taču praksē ar to ir saskāries katrs autors, kas izmanto mutvārdu komunikācijā iegūtos materiālus; un, jo plašăku areālu kāda vārdnīca aptver, jo vairāk variantù. Bez tam svarīgi ir nošk̆irt tā saucamos izrunas variantus, kas pārceltajā formā neparādās, no īstajiem variantiem.

Latviešu valodas vārdnĩcās (it îpaši tulkojošajās divvalodu vai vairākvalodu vārdnīcās), sākot jau ar 17.gs., ir ieklauta arī dialektālā leksika, kas apzīmēta ar īpašām vietas norādēm, piemēram,

Puhme eine beule Curl. Fìr. I, 178,

danga Winkel Tahm. St. 34,

dardedze Regenbogen Obl. St. 34.

Nominācijas varianti reizēm ir doti vai nu iekavās aiz šķirk|a vārda vai šḳirk]a vārda ligzdā, piemēram,

Petrinsch. Curl. Zeplitis. Sem. der kleine Ofen in der vor Rije Fīr. I, 173,

Preewite, apsehhja ein hosen=band Fìr. I, 176,

Śnahtne (Pamawa, Uhswalcka) eine Grobe Leindwandt Decke, so die Lettinnen umb sich werffen vnd zubreetzen Lg. 2, 71. 
Šajās vārdnīcās parasti tiek pievērsta uzmanība leksēmai, nevis atsevišḳiem tâs variantiem. Tikai atsevišḳos gadījumos ir mêgināts norādìt arī gramatiskos variantus, piemēram,

pahrmati, pahrmatkhi Ueberwurfrock St. 185,

peedurkne, (peedrohkfne) Ermel St. 190 (iespējams, ka piedurkne un piedurksne nav gramatiskie varianti, bet gan dažāàdas cilmes vārdi).

Latviešu literārās valodas vārdnīcā, kur ar norādi apv. ievietoti arī nedaudzi dialektālās leksikas vārdi, attieksme pret variantiem (parasti tie gan nav apvidvārdi) formulēta īsi:

"Vārda fonētiskie vai morfologiskie varianti parasti doti katrs savā šķirklī. Vienā šķirklī apvienoti 1) fonētiskie un morfologiskie varianti, kas alfabēta secībā atrodas tieši blakus vai tuvu viens otram (lasmenis, lāsmenis), un 2) vārdu pāri ar $k s ̌ k$ - un -kšs- (blīkškset, blīkšet t)" LLVV 1, 10.

Latviešu dialektālā leksikogrāfija līdz šim nav izgājusi ārpus vienas izloksnes leksikas apkopojuma', tādē] visai maz saskārusies ar variantu pārbagātību un to noteikšanas kritērijiem " "Ërg̀emes izloksnes vārdnīcā" vienā škirklī apvienoti:

fonētiskie varianti ar 1) atšķirīgu saknes patskani, piemēram, cẹlât un cilât ĒIV 1, 205, izdùnkât un izdònkât ẼIV 1, 457; 2) atškirīgu (parasti balsīgo un nebalsīgo) līdzskani, piemēram, čẹñùrrs un čẹngùrrs ĒIV 1, 232; 3) dažādu saknes intonāciju, piemēram, bùolît un buôlît ÉIV 1, 196;

1 Kagaine E., Rag̀e S. Erg̉emes izloksnes vārdnīca. 1.-3.sēj. R., 19771983; Reķēna A. Kalupes izloksnes vărdnīca. 1.-2.sēj. R., 1998; Ādamsons E. Kagaine E. Vainižu izloksnes vărdnīca. 1.-2.sēj. (manuskripts).

2 Ar variantu noteikšanu ir saskārušies "Latviešu valodas dialektu atlanta" veidotāji un visi tie, kas veic pētījumus par atseviškām leksikas tematiskajām grupām, piemēram, B.Bušmane par édienu nosaukumiem, I.Edelmane - par augu nosaukumiem, I.Kurzemniece par žogu nosaukumiem u.c. 
morfologiskie varianti ar 1) dažādām galotnēm, piemēram, bùrlaks un bùrlaka EIV 1, 198; 2) atškirīgām izskaṇām, piemēram, četrkantainš un četrkantains ËIV 1,233.

Uz nominācijas variantiem šajā vārdnīcā norāda zĩme $=$, piemēram, dāvâna 1. 'dāvana' = II šķin̄ikis; 2. 'dotības' = duôtíbas EIV 1, 250; cẹri = ķereži ĒIV 1, 211.

Līdzīgi tas tiek darīts arī citās minētajās izlokšnu vārdnīcās.

Visvairāk variantu sastopams t.s. latviešu valodas tēzaurā K.Mīlenbaha un J.Endzelīna "Latviešu valodas vārdnīcā" un tās "Papildinājumos", taču šeit grūti runāt par objektīviem variantu noškiršanas kritērijiem. Vērojams, ka vienā šķirklī ir mēg̀ināts apvienot maksimāli daudz variantu, nesaistot tos ar konkrēto vārda semantiku un izplatîbu, piemēram,

draca, drace, dracis, dracka Lärm, ausgelassenes, lautes, mit Prügelei endendes Aufleben, Prügelei: krogū bija liela drace Salis, Schujen, Adsel, Druw., Alt-Rahden, Lös. Etn. IV, 18. ME I 488. (Minēts monosēmisks కķ̧irk]a vārds ar trim variantiem un sešãm registrācijas vietām, taču nav skaidrs, kurš variants fiksēts katrā izloksnē.);

cirmis Wid., auch in Livl. gehört, cirmenis, cirmẹns $\mathrm{C}$. cirmene Selb., cirminšs, cirminis Nerft, Michalowo, cirmulis ${ }^{2}$ Adsel, Demin. cirmenītis, cirmentinš, 1) der Wurm, die Made, die Milbe: ei, sarkanais ābuolin, cirmen(i)s tavu sakni grauza BW. 12285; 2) die Raupe: nuo uolinas attīstâs cirmentiňs Konv. 27; 3) tranu cirmini, Drohnenbrut. ME I 386 . (Minēts polisēmisks vārds ar 7 gramatiskajiem variantiem, taču nav skaidrs, kurai nozīmei atbilst šie varianti.)

Lietuviešu valodā ir izdotas samērā daudzas izlokšņu vārdnīcas ${ }^{3}$, bet nav apkopojošas lietuviešu izlokšnnu vārdnīcas. Šo tukšumu dajēji aizpilda akadēmiskā lietuviešu valodas

3 Petrauskas J., Vidugiris A. Lazūnu tarmès žodynas. Vilnius, 1985; Naktinienè G., Paulauskienė A., Vitkauskas V. Druskininku tarmes zodynas. Vilnius, 1988; Vidugiris A. Zietelos (lietuviešu sala Baltkrievijā) Šnektos žodynas. Vilnius, 1998. 
vārdnīca "Lietuvių kalbos žodynas", kur ievietots arī samērā daudz izlokšņu leksikas. Variantu nošķiršanā ievērots leksikogrāfiski vienkāršots princips izdalīt katru variantu atsevišksā šķirklī, piemēram,

kamãsas (I. kamasz, vok. Gamasche) 'nesuvarstomi pusbačiai su auliukais' LKŽ 6, 172; kamãs̆e = kamašas LKZ̆ 6, $173 ;$ kamäšis $=$ kamašas LKŽ 6, 173,

kamzelka (l. kamzelka) = kamzolè LKZ̆ 5, 192; kamzelkinis

kamzelka LKŽ 5, 192; kamziōlè = kamzolè LKŽ 5, 192; kamzülè = kamzolè LKŽ 5, 192; kamzôlè 'liemenè' LKŽ 5, 192; kamzolis = kamzolè LKŽ 5, 192; kamzūle = kamzolè LKZ̆ 5,192; kamzuôle 'švarkas su liemeniu ir skvernais, durtinys'; = kamzolè LKZ̆ 5, 192.

Izlokšnu vārdnīcas ir vairāku Zieme|valstu uzmanības lokā; devingdesmitajos gados ir nākuši klajā igauṇu, somu un zviedru izlokšnu vārdnīcu pirmie sējumi ${ }^{5}$, taču, nepārzinot šo valodu dialektālo fonētisko transkripciju, ir grūti spriest par variantu apvienošanas principiem (t.i. atsevišķu dažādi atzīmētu skaṇu dinamiku), taču šksiet, ka šie principi ir samērā tāli no "Latviešu izlokšṇu vãrdnīcas" koncepcijas un dialektālās transkripcijas.

Samērā sen pie izlokšņu vārdnīcām darbu ir sākuši krievu (un arī citu slāvu valodu) leksikogrāfi ${ }^{6}$

Ielūkojoties krievu, baltkrievu un po|u izlokšṇu vārdnīcās, kuras visvairāk tiek izmantotas, lai rastu etimologiskās un semantiskās paralēles ar Latgales valodas materiālu, redzams, ka variantu atspogujošanā nav ievērota konsekvence pat viena

${ }^{4}$ Lietuvių kalbos žodynas. I - (XVIII) - Vilnius, 1968 - (1997) -

${ }^{5}$ Eesti murrete sõnaraamat. I - Tallinn, 1994 - ...; Suomen murteiden sanakirja. I - Helsinki, 1995 - ...; Ordbok över sveriges dialekter. I ... Uppsala, 1991 -

6 Stownik gwar polskich. I - Wrocław-Warszawa-Kraków-GdańskŁódż. 1982 - ...; Словарь русских народных говоров. I - МоскваПсков, 1965 Псковский областной словарь. I Ленинград, 1967 ...; Слоўнік беларускіх гаворак паўночна-заходняй Беларусі i яе пагранічча. I - V. Мінск, 1979 - 1986. 
sējuma robežās. Šḳiet, labākais variants ir atrasts Pleskavas izloksnes vārdnīcā (diemžēl nekonsekventi). Piemēram šḳirk|u grupa, kas saistita ar pamatšķirkli валенкu.

өаленки 'зимние теплые сапоги, скатанные из шерсти' + валёнки. Ср. валёники, валенцы, валены, вальки, катанки; валеночки, валенчики, валемки; валенчищки; валенчуги. Bар. өалёнки. ПОС 3, 21-22.

валёники. То же, что валенки. ПОС 3, 21.

валеночки и валенечки. УМ.-ласк. $\rightarrow$ валенки. Ср. валенчики, валешки. ПОС 3, 22.

валенцы. То же, что валенки. ПОС 3, 22.

валенчики. То же, что валеночки. ПОС 3, 22.

валенчишки. Пренебр. $\rightarrow$ өаленки. ПОС 3, 22.

валенчуеи. Экспр. 'большие валенки' ПОС 3, 22.

валены. То же, что валенки. ПОС 3, 22.

вальки. То же, что валенки. ПОС 3, 29.

валеики. УМ.-ласк. $\rightarrow$ валенцы. Ср. валеночки. ПОС 3 , 23.

Pamatšķirklí өаленкu ar norādi salīdzināt ir saistīti -vārdi валеники, валенцы, валены, вальки, катанки; валеночки, валенчики, валешки; валенчиики; валенчуғи. Visi norādītie vārdi ir izdalīti atsevišķos šķirkjos, bet atšķirīga ir to leksikogrāfiskā apdare. Piemēram, varianti валеники, валенцы, валены, вальки ir sasaistīti ar pamatšķirkli валенки ar skaidrojumu "To же, что валенкu", tādē] arī tie pamatšķirk]a da|ā doti pirmie un atdalīti ar komatu. Aiz semikola nākošo grupu veido trīs deminutīvi ar emocionāli ekspresīvo slodzi, tie ir валеночки, валенчики, валешки, taču to skaidrojumos dotās norādes nešķiet konsekventas: валеночки pamaz.-mīlin. no валенки; валенчики tas pats kas валеночи; валешки pamaz.mīlin. no валенцы. Trešo grupu veido vārdi валенчиики, kas vārdnīcā ievietots ar norādi nievājošs no валенки, un валенчу?и - ar norādi ekspresīvs un skaidrojumu 'большие валенки' 
Kāds celš ejams "Latviešu izlokšṇu vārdnīcas" veidotājiem? Tas atkarīgs, pirmkārt, no värdnīcas mērka un, otrkārt, no izlokšņu materiāla kvalitātes un kvantitātes.

Latviešu izlokšnu vārdnīcai ir izstrādāta noteikta šķirkła struktūra, kuras komponenti ir:

$\sim$ fonētiskais un morfologiskais raksturojums;

areālā izplatība un/vai reǵistrācija lıngvistiskos avotos;

$\sim$ semantiskais raksturojums;

stilistiskais raksturojums;

$\sim$ etimologiskais raksturojums.

Par škirkla pamatu tiek uzlūkots izloksnes vārds pārceltajā formā, taču šeit jau rodas pirmā problēma - nošksirt pārcelto formu no izloksnes formas, resp., noteikt vokāla vai diftonga kvalitāti.

Kā redzams no izstrādātās šķirk|u struktūras, "Latviešu izlokšṇu vārdnīca" ir universāla vārdnīca ${ }^{7}$, kurā apvienots leksiskais (semantiskais) un gramatiskais aspekts un, kuras uzdevums ir sniegt maksimāli objektivvu informāciju par:

1) vārda vai vārda nozīmes semantiku,

2) leksēmas gramatisko raksturojumu,

3) fonētisko veidolu, to visu saistot ar konkrētu izplatỉbas areālu.

Diemžēl darbu pie vārdnīcas apgrūtina nevienmērīgais materiālu vākums ${ }^{8}$, jo ir izloksnes, kuru kartotēkas sasniedz un pat pārsniedz 100000 leksikas vienību (Ëǵgeme, Sinole, Nīca, Kalupe u.c.), un ir izloksnes, no kurām vai nu vispār nav izlokšnu materiālu vākumi, vai arī to skaits nepārsniedz dažus simtus.

Ņemot vērā iepriekš izteiktos apsvērumus, lai panāktu pēc iespējas precizāku leksisko un gramatisko parādību

\footnotetext{
${ }^{7}$ Kagaine E. Semantiskā aspekta loma izlokšnu vārdnīcu tipa izvēlę. Lietuviu kalbotyros klausimai. XXXVII. Vilnius, 1997, 127.-136.Ipp. 1998.gadā latviešu izlokšnu leksikas kartotēka ir sasniegusi 1300000 vienỉbu (Latviešu valodas dialektu atlants. Leksika. (manuskripts))
} 
atspogu|ojumu vārdnīcā, vajadzētu pēc iespējas izvairīties no daudzu gramatisko variantu apvienošanas vienā šķirk|ī.

Apvienot vienā šḳirklī varētu vārdus:

- ar dažādu fonētisko struktūru:

1) ar mainīgu uzsvara vietu, piemēram, bišķìin, biš 'kīitin; biškītin, biśs 'kītin 'nedaudz, mazliet',

2) ar atšḳirīgu vokā]a kvalitāti, piemēram, blumizers, blümizers 'mutes harmonikas',

3) ar dažādu līdzskaṇu kvalitāti un kvantitāti, piemēram, blitkuot, blitkuot 'zvejot ar zemledus vizuli; žibulēt';

- ar atšḳirīgu morfoloǵgisko struktūru:

1) ar atškirīgu nomenu celmu, piemēram, blīgzna, blïgzne

'vītolu dzimtas koks, arī krūms',

2) ar atškirîigu verba celmu, piemēram, blūdāt, blūiēet, blūdīt

'maldīties, arī bezmērksīgi klaiṇot',

4) ar dažādiem sufiksiem, piemēram, blikstiens, blikstiņš 'acu plaksts'

Taču, lai šādus vārdus apvienotu vienā šķirkJī, iir jāsaskan vismaz daḷai pārējo komponentu, proti, semantiskajam, stilistiskajam un etimologiskajam raksturojumam. Problëma rodas tad, ja nevienmērīga materiālu vākuma dēl nevar precīzi noteikt vārda semantiku. Ja nesakrīt vārda areālais raksturojums (vispārīgās geogrāfiskās norādes) ${ }^{9}$, tad ir divas iespējas:

1) ja kāds no variantiem (vai visi varianti) ir registrēts sporādiski dažādos Latvijas apgabalos, tos var apvienot, norädot katra varianta konkrēto registrācijas vietu;

2) ja kāds no variantiem veido noteiktu izplatības areālu, lietderīgāk ir šo variantu izdalīt atsevišksā šķirklī, jo tas var norādīt uz kāda dialekta vai izlokšņu grupas īpašu pazīmi, piemēram, leksēma bastene 'batista lakats' ir izplatīta vidus dialekta kursiskajās izloksnēs, bet šīs

9 Skat. Jansone I. Vārdu un vārda nozīnju areālais raksturojums nediferenciālā izlokšnu vārdnīcā. Lietuvị kalbotyros klausimai. XXXVII. Vilnius, 1997, 137.-144.lpp. 
leksēmas variants bastainis 'batista lakats' vidus dialekta izloksnēs Vidzemē un augšzemnieku dialekta izloksnēs Vidzemē.

Ja leksēmas ir uzlūkojamas par gramatiskajiem variantiem, kas dodami vienā šḳirklī, tad var būt atšksirīgs to grafiskais noformējums. Variantus var rakstīt vienu aiz otra virknē, par pirmo izvēloties vai nu izplatītāko, vai konsekventi saglabājot alfabētu, piemēram, blikata, blikita 'spēle, kuras dalïbnieks no attāluma, sitot ar nūju, cenšas izjaukt (no kādiem priekšmetiem saliktu) figūru veidojumu' Var arī izvēlēties tā saucamo iesprauduma principu, kad īsāko variantu papildina ar iespējamiem burtiem kvadrātiekavās, piemēram, bal(a)mute, bal(a)mutis (tātad iespējami 4 varianti: balmute, balamute, balmutis, balamutis); blurkš( $(k) \bar{e} t$, blurkstêt (iespējami varianti blurkšèt, blurkšksēt un blurkstēt). Praksē visbiežāk nākas izmantot abu šo principu apvienojumu. Lai "Latviešu izlokšnu vārdnīcā" ietvertā informācija būtu nepārprotama, vienā šķirklī apvienotajiem gramatiskajiem variantiem jānorāda konkrētā izplatības vieta. Tātad šķirkla struktūra jāveido tā, lai būtu iespējarns noteikt katra konkrētā varianta lietojumu izloksnē. Vispirms konkrētais variants realizēsies ilustratīvajā materiālā, taču, ja leksēma aptver plašāku areālu, tad, dodot konkrētās geogrāfiskās norādes, būtu jāuzrāda vispirms variants un tikai tad izloksnes, piemēram, bruceklis 'galoda (parasti izkapts asināšanai)' Dundagā, Kuldīgā, Saldū, Ivandē utt., brucekls Dunikā, Grobiṇā, Kalētos, Bārtā, Rucavā. (Izmantojot vispārinātās areālās norādes, šo principu gan nebüs iespējams ievērot.)

Bez tam leksikogrāfijas praksē ir jādomā arī par gramatisko un nominācijas variantu sasaisti visas vārdnīcas ietvaros.

Diemžēl latviešu leksikogrāfijā šī problēma praktiski nav risināta, jo K.Mīlenbaha un J.Endzelīna "Latviešu valodas vārdnīcā”, kas ir praktiski vienīgā vārdnīca, kurā ieklauts arī 
plašā areālā mutvārdu komunikācijāā iegūtais materiāls, norāžu sistēma nav izstrādāta, bieži pat nav iespējams vārdu sasaistīt ar konkrētu nozīmi vai izplatỉbas areālu.

Gramatisko variantu sasaistei būtu pieņemams šāds modelis: pamatšḳirklis (literārais variants vai izplatītākais variants) sasaistīts ar gramatiskajiem variantiem ar norādes

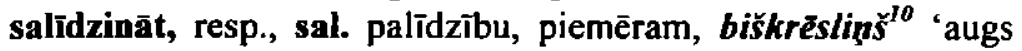
(Tanacetum vulgare)' Sal. bikrēsliņš, bikrēslis, biskrēeslin̄š, biskrēsliňs, biškrēsls. Šo variantu skaidrojumam vajadzētu izmantot pamatšķirḳ̣a vārdu (pirms tā liekot vienlīdzîbas zīmi), piemēram, bikrēsliņš biškrēsliņš. Šāds šksirkla izveides modelis |autu izvairīties no vairākkārtējas gramatisko variantu atkārtošanas pie katra no variantu škirkliem.

Ja vienā škirklī ir apvienoti vairāki gramatiskie varianti, tie atkārtoti jāieklauj vārdnīcā alfabētā (izṇēmums varētu būt tad, ja šie varianti seko alfabētā tieši viens aiz otra). Vienā šksirklī apvienoto gramatisko variantu sasaiste jāveic izmantojot norādi skatīt, resp., sk. (Šie varianti, atšķirībā no atsevišḳā šḳirklī izdalītajiem, veidotu nepilnā jeb sasaistošā šksirkla modeli).

"Latviešu izlokšṇu vārdnīcā" tās ideālajā variạtā gribētos atrast vienkopus arī nominācijas jeb sinonīmiskos variantus, taču rakstīšanas procesā tas laikam nebūs iespējams. To varētu mēgènāt veikt rediǵēšanas procesā, izmantojot perfekti izstrādātu datorprogrammu.

Taču šis jautājums lai paliek kā nākotnes perspektīva.

\section{VARIANTES DU DICTIONNAIRE DES PARLERS: LES PROBLÈMES ET LES SOLUTIONS Résumé}

Une structure concrète est élaborée dans le "Dictionnaire des parlers lettons" avec les composants suivants:

${ }^{10}$ Piemēros nav dota pilna šķirkja struktūra. 
caractéristiques phonétique et morphologique; linguistiques;

étendue aréale et/ou la fixation dans des sources

- caractéristique sémantique;

- caractéristique stylistique;

- caractéristique étymologique.

On pourrait unir dans une même entrée des mots avec une structure phonétique différente (a) avec un accent variable, b) avec une qualité vocalique différente, c) avec une quantité et qualité différente des consonnes) et une structure morphologique différente. Pour réunir ces mots sous une entrée il faut que tous les composants (étendue aréale, caractéristiques sémantique, stylistique et étymologique) ont les mêmes paramètres.

$\mathrm{Si}$ les lexèmes sont considérés comme des variantes, ils peuvent avoir un autre aspect graphique. Ces variantes peuvent se suivre l'un après l'autre et le premier serait le plus fréquent, soit respectant l'ordre alphabétique, soit en utilisant le principe intercalaire, on choisi, par exemple, la variante la plus courte et on lui ajoute des lettres mises entre des crochets. bal[a/mute, bal[a]mutis quand il est possible d'avoir quatre variantes (balmute, balamute, balmutis, balamutis). L'expérience pratique démontre qu'on utilise ces deux principes à la fois.

Dans le dictionnaire, il faut aussi lier les lexèmes qui ne sont pas inclus de telle ou telle façon sous la même entrée, mais qui peuvent être considérées comme variantes; Dans ce cas on pourrait utiliser l'indice comp. (comparer), par exemple, à la fin de l'entrée biškrēsliṇš 'tanaisie vulgaire' (Tanacetum vulgare) sous l'indice comp. on énumère bikrēsliṇi, bikrēšs $\mid$, biskrēslini, biskrēslini, biškrēsli. Il reste encore à résoudre s'il faut donner comp. après chaque variante ou seulement après l'entrée principale, car on trouve une argumentation pour les deux cas. 


\section{Elga KAGAINE \\ VĀRDU CILMES NORĀDES DIALEKTĀLAJĀS VĀRDNĪCĀS}

Ikvienam vārdnīcas tịpam kā vispārīgajā, tā dialektālajā leksikogrāfijā šķirk|a sastāvā ir raksturīgi noteikti elementi dažādas norādes, nozīmju skaidrojumi u.tml., kas nepieciešami attiecīgajai vārdnīcai izvirzīto mērķu atklāsmē. Tā, piemēram, skaidrojošajās vārdnīcās dominē vārda semantikas analīze un nozīmes skaidrojums, sinonīmu vārdnīcās sinonīmu rindas semantiskais, stilistiskais un hronologiskais raksturojums, bet izlokšṇu vārdnīcām obligāti nepieciešami šksirk|a elementi ir vārda nozīmes skaidrojums un geogrāfiskās izplatības raksturojums, norādes par vārda lietojumu noteiktās izloksnēs vai izlokšṇu grupās. Cita informācija dažādas stilistiskās, hronolog̣iskās un etimologiskās norādes, ziṇas par vārda registrāciju vēsturiskajā literatūrā, leksikogrāfiskajos avotos un dialektologiskajos pētījumos - ir Joti vēlama, taču lielā mērã atkarīga no rīcībã esošā materiāla un tā izmantošanas iespējām.

Vārdu cilmes skaidrošana ir viens no lingvistiski grūtākajiem uzdevumiem un, kā rāda dialektālās leksikogrāfijas publikācijas, daudzu valodu izlokšņu vārdnīcu veidotāji no šî uzdevuma ir arī atteikušies, atstājot vārdu cilmes jautājurnu risināšanu speciālajām etimologiiskajām vārdnīcām. Tā, piemēram, norāău par vārdu cilmi nav igaunu', somu², zviedru', krievu $u^{4}$ polu ${ }^{5}$ u.c. topošajās izlokšṇı vārdnīcās. Šajās valodās, protams, ir publicētas etimologisskās vārdnīcas, kur vairāk vai

\footnotetext{
${ }^{1}$ Eesti murrete sõnaraamat. [ - Tallinn, 1994 -

${ }^{2}$ Suomen murteiden sanakirja. I Helsinki, 1985 -

${ }^{3}$ Ordbok över Sveriges dialekter. Bd. I, H. 1. Uppsala, 1991.

${ }^{4}$ Словарь русских народных говоров. I Москва-Ленинград, 1965 - ; Псковский областной словарь с историческими данными. I - Ленинград, 1967 -

${ }^{5}$ Stownik gwar polskich. I - ... Wrocław-Warszawa-Kraków-GdańskŁódż. $1982-\ldots$
} 
mazāk detalizēti ir iespējams iepazīties ar daudzu attiecīgajā valodā lietoto vārdu cilmi ${ }^{6}$ Tomēr cilmes norāžu nepieciešamību izlokšņu vārdnīcās lielā mẻrā balsta fakts, ka šîs vārdnīcas ietver ievērojamu perifêrās leksikas da|u, kas citur nav registrēta un tātad par to nav informācijas arì kopvalodas etimologiskajās vārdnīcās, ja vien par kādu izlokšṇu leksikas grupu nav veikti īpaši pētījumi, kur līdztekus ar citiem analīzes aspektiem risināti arī attiecīgo leksēmu cilmes jautājumi (piemēram, izlokšṇu leksikas grupu tematiskie un areālie pētījumi; latviešu valodā šajā aspektā var minēt B.Laumanes ${ }^{7}$, B.Bušmanes ${ }^{8}$, A.Reķēnas ${ }^{9}$ u.c. autoru publikācijas). Tāpēc izlokšnu vārdnīcās vārdu cilmes

6 Sk., piemēram, Suomen kielen etymologinen sanakirja I-VII. Helsinki, 1955-1981; Suomen sanojen alkuperä I ..., Helsinki, 1992...; Mägiste J. Estnisches etymologisches Wörterbuch I-XII. Helsinki, 1982-1983; Фасмер $M$. Этимологический словарь русского языка I IV Москва, 1964 - 1973; Этимологнческий словарь русского языка I (под ред. Н.М. Шанского). Москва, 1963 - ...; Этимологический словарь славянских языков I - (под ред. О.Н. Трубачева) Москва, 1974 -

${ }^{7}$ Laumane B. Zivju nosaukumi latviešu valodā. R., 1973; Laumane B. Vienkoča laivas nosaukumi. - LPSR ZA Vēstis, 1973, $\mathrm{N}^{\circ} 2$; Laumane $B$. Par dažiem Baltijas jūras floras un faunas nosaukumiem. - Latviešu valodas kontaktu pētijumi. R., 1987, 163.-185.lpp: Laumane $B$. Zebiekstes nosaukumi latviešu valodā. Turpat, 186.-198.Ipp.; Laumane B. Zeme, jūra, zvejvietas. R., 1995, 400 lpp.

${ }^{8}$ Bušmane $B$. Edienu nominācija latviešu valodas izloksnēs. - LPSR ZA Vēstis, 1986, N8, 70.-81.Ipp. Buśmane $B$. Galertveida ēdienu nosaukumi izloksnēs. Latviešu valodas kontaktu pētijumi. R., 1987, 86.-137.lpp.; Bušmane B. Komentārs "Latviešu literārās valodas vārdnīcas" ş̣̂irklim iešncova. - LZA Vēstis, 1994, № 9/10, 30.-37.lpp.; Bušmane B. Aizguvumi piena produktu nosaukumos latviešu valodas izloksnēs. - LZA Vēstis, 1996, $\mathrm{N}^{\circ} 2$, 6.-14.lpp.

${ }^{9}$ Reķēna A. Amatniecības leksika dažās Latgales dienvidu izloksnēs un tās sakari ar atbilstoßajiem nosaukumiem slāvu valodās. R. 1975, 707 lpp.; Rekēena $A$. Slāvismi Latgales dienvidu izlokšņu ēdienu leksikā. Dialektālās leksikas jautājumi II. R., 1986, 57.-96.lpp. 
norādes ir loti vēlamas un šādu norāžu izstrāde, veidojot vārdnīcu, ir visai aktuāla.

Rakstā aplūkotā tēma par etimologiskajām norādēm izlokšnu vārdnīcās ir saistīta ar vienu no latviešu dialektālās leksikogrāfijas turpmākajiem uzdevumiem jaunas, apvienotas "Latviešu izlokšnu vārdnīcas" veidošanu. Vārdnīca, pamatojoties uz latviešu dialektālās leksikogrāfijas tradīcijām, tiek veidota kā izlokšñu skaidrojošā vārdnīca, kurā apvienoti sinhronijas un diahronijas elementi - sasaiste ar K.Mīlenbaha "Latviešu valodas vārdnīcu" un tās Papildinājumiem ${ }^{10}$ un ìsa informācija par vārdu cilmi (diahroniskais aspekts), bet sinhroniskajā plāksnē mēgināts izlokšnuu leksiku iek|aut sistēmā, kas atspogu|otu esošo stāvokli.

Izlokšñu vārdnīcām vārdu cilmes skaidrojumos nevar izvirzīt tādus mērḳus, kādi ir speciālajām etimologiskajām vārdnīcām, jo to uzdevums nav atvedināt vārda attīstības atspogulojumu līdz pirmvalodai (vai kādai radniecīgu valodu grupai), izsekojot visām skaṇu mijām un atbilsmes likumsakarỉbām un nosakot vārdu radniecību ar tās pašas vai citas valodas vārdiem. Tātad dialektālo un etimologisko vārdnīcu cilmes skaidrojumu atšḳirības vispirms ir mekłējamas aplūkojamo vārdu cilmes rekonstrukcijas pakāpē. Izlokšṇu vārdnīcās cilmes norāžu uzdevumi būtu saistāmi, pirmkārt, ar izlokšṇu un kopvalodas (literārās valodas) attieksmēm un atšķirībām, resp., aplūkojami vienas valodas dažādu sistēmu un apakšsistēmu limmeñ, piemēram, norādes uz dialektālām, skaṇu pārmaiṇu izraisītām parādībām metatēzi, disimilāciju, skaṇu zudumu u.tml., norādes par vārdu vai formu kontamināciju, kāa arī citiem faktoriem, kas ir ietekmējuši vienas vai otras dialektālās leksēmas veidošanos.

Nākošā cilmes norāžu pakāpe is starpvalodu limmenī, tā skar attieksmes ar kaimiṇvalodām un ir saistīta ar aizguvuma avota konstatāciju vai arī hibrīdleksēmu komponentu noteikšanu. Arī

${ }^{10}$ Millenbahs K. Latviešu valodas vārdnīca. I IV R. 1923 - 1932; Endzelīns J., Hauzenberga E. Papildinājumi un labojumi K. Mīlenbaha Latviešu valodas vārdnīcai. I - II. - R., 1934 - 1946. 
aizguvuma avota konkretizācijas pakāpe var būt dažāda - tā var būt visai aptuvena tikai ar norādi uz valodu grupu, no kuras nācis attiecīgais aizguvums (slāvisms, germānisms, hibrīdforma) vai vēl vispārinātāk "svešas cilmes vārds" Šāda pieeja cilmes atspogulojumā ir, piemēram, vairākās lietuviešu izlokšṇu vārdnīcās - "dūnininku" izlokšṇu vārdnīcā," Lazūnu izloksnes vārdnīcā ${ }^{12}$ un Druskininku izloksnes vārdnīcā ${ }^{13}$ Diferencētas pieejas gadījumā aizguvuma avots jau ir konkretizēts un norādes atspogulo konkrētu vārdu (vai vārdus), kas ir (vai varētu būt) kāda aizguvuma pamatā. Bez tam šĩ analīze un salīdzinājums var notikt arī tipoloǵiskā plāksnē, atspogulojot semantiskās ietekmes un semantiskās paralēles vai arī citas tipologiski paralēlas parādības. Dialektālajās vārdnīcās galvenā vērỉba cilmes norāžu ziṇā ir pievērsta perifērās leksikas slānim, kas neietilpst kopvalodas sastāvā, un vārdnīcas, kurās ir dotas cilmes norādes, var uzlūkot par specifiskām, da|ê̄ji etimologiskām dialektālām vārdnīcām. Šāda ievirze ir, piemēram, vairākām vācu izlokšṇu (Tîringas, Lejassaksijas u.c.) vārdnīcām, kur vārda semantiskā un areālā analīze nereti atklāj arì vārda vai nozīmes veidošanās vēsturi un cilmi.

Cilmes norāžu ziṇā "Latviešu izlokšnu vārdnīcā" iek|auto leksiku var sadalīt divās lielās grupās vārdi ar etimologijas ncrādēm un tie, kuriem šādu notāžu nav. Bez norādēm, protams, paliek tā leksikas daja, par kuras cilmi nav ziṇu etimologiskajos avotos un arī vārdnīcas autoriem nav izdevies atrast faktus, kas varētu dot kādu impulsu vārda cilmes skaidrojuma meklējumos. Tāpat bez cilmes norādēm paliek ievērojama da|a afiksālo atvasinājumu un salikteņu.

Otru grupu veido vārdi ar etimologijjas norādēm, kas gan pēc sava satura, gan apjoma var būt loti dažādas. Pirmajā

1 Vitkauskas $V$ Šiaurès rytu dūnininkų šnektu žodynas. Vilnius, 1976.

${ }^{12}$ Petrauskas J., Vidugiris A. Lazūnu tarmès žodynas. - Vilnius, 1985.

${ }^{13}$ Naktiniene G. Paulauskienè A., Vitkauskas V. Druskininku tarmès žodynas. Vilnius, 1988. 
apakšgrupā ietilpināmi vārdi, kuriem šķirk|a beigās pievienotas norādes uz kādu publicētu etimologiskās informācijas avotu (ME, EH, K.Karula "Latviešu etimologijas vārdnīcu"14, E.Frenke|a "Lietuviešu etimologiisko vārdnīcu" dialektolog̀isku vai etimologisku pētîjumu vai citu publikāciju), kur attiecīgā vārda vai tam radniecīgu vārdu cilme ir aplūkota sīkāk un interesenti var iegūt plašākas ziṇas par aplūkojamo jautājumu. Šảas konspektīvas norādes (tikai ar informācijas avota šifru) paredzēts dot galvenokārt vispārlietojamiem, etimologiskajās vārdnīcās ietvertiem vārdiem (piemēram, ar šādām norādēm var tikt raksturoti mantotie vărdi balts, bradāt, brälis, brēkt, brist u.d.c.). Taču cilmes norādes var būt arī izvērstākas, var tikt citēti kāda pētījuma fragmenti, kur norādīts, piemēram, aizguvuma avots vai kāda cita informācija par vārda vēsturi. Daži piemēri: bele Kokvilnas diedziņi, ko parasti izmanto audekla velkiem Ṣ̌irkla beigās seko cilmes norāde, ka vārds aizgūts no baltkrievu vai po|u izlokšņu бель (ar to pašu nozīmi) un atsauce uz A.Reḳēnas pētījumu, no kurienes ṇemta attiecīgā informācija ${ }^{16}$; birulis Aužamo stāvu deta|a trīzula ripa, kam apmet auklu Seko norāde par vārda saistību ar baltkrievu izlokšñu бирулкi (ar to pašu nozīmi) un arī atsauce uz A.Reķēnas darbu ${ }^{17}$; biēstapiēns; biêstpiēns Jaunpiens Škirkla beigās seko norāde par aizguvumu no vācu valodas (vācu Biest, Biestmilch 'jaunpiens') un atsauce uz B.Bušmanes rakstu, kur šīs leksēmas aplūkotas sīkāk ${ }^{18}$; bieršksis Asaris Seko norāde par

${ }^{14}$ Karulis K. Latviešu etimolog̀ijas vārdnīca. I - II. R., 1992.

is Fraenkel E. Litauisches etymologisches Worterbuch. I II. Heidelberg; Göttingen, 1962-1965.

${ }^{16}$ Rek̦ēna A. Amatniecības leksika dažās Latgales dienvidu izloksnēs un tās sakari ar atbilstošajiem nosaukumiem slāvu valodās. R., 1975, 353.lpp.

${ }^{17}$ Turpat, 372.lpp.

${ }^{18}$ Bušmane $B$. Aizguvumi piena produktu nosaukumos latviešu valodas izloksnēs. - LZA Vēstis, 1996, N² 2, 11.lpp. 
aizguvumu no vācu dialektālā vārda Berschke un atsauce uz B.Laumanes pētījumu ${ }^{19}$

Atsaucoties uz vairākiem etimologisko zinuu avotiem, nereti nākas saskarties ar pilnīgi vai da|ēji atšksirīgu vārda cilmes skaidrojumu. Arĩ šajos gadījumos paredzētas piebildes par to, ka attiecīgā vārda cilmes skaidrojumā pastāv atšksirīgi viedok|i, norādot uz to ar piezīmi "citādi" vai arī citējot attiecīgo pētījumu fragmentus. Piemēram, brangs ME I 323 - 324 uzlūkots par aizguvumu (Als Lehnwort aus dem Kurischen od. Litauischen wohl zu d. Prunk resp. mhd. prangen "sich zieren, prahlen".). Citāds skaidrojums rodams K.Karu|a "Latviešu etimoloǵijas vārdnīcā" (pamatā ide. sakne *bhren- 'tūkt, izcelties' ar $g$ paplašinājumā); sk. LEV I 141.

Daudzos gadījumos vārdnīcas autoriem nākas patstāvīgi risināt vārdu cilmes skaidrošanu. Šeit analizējamā materiālā ietilpst galvenokārt dialektālās leksēmas, dažādi lokālie aizguvumi, salikteṇi, hibrīdformas u.c. leksikas vienibas, kas vai nu reǵistrētas tikai pēdējos piecdesmit gados vai arī (atbilstoši toreiz J.Endzelīna pieñemtajiem vārdu atlases principiem) netika jek|autas līdzšinējā plašākajā izlokšnu leksikas apkopojumā - K. Mîlenbaha "Latviešu valodas vârdnīcā" un tās Papildinājumos, un tāpēc to cilmes apskats bieži vien jāveic pirmoreiz. Šo leksēmu vidū ir daudz lokālu aizguvumu: lejzemnieku izloksnēs - germānismu, bẹt augšzemnieku dialektā - slāvismu vai ar slāvu valodu starpniecību pārṇemtu vârdu. Da|ai relatīvi jaunāka slāṇa aizguvumu ir visai "caurspīdiga" etimolog̀ija, resp., ir diezgan precīzi konstatējams fonētiski atbilstošs un daudzreiz arī semantiski idents aizguvuma avots.

Dażi piemēri:

beksene 1. Vecs, neglīts trauks (krūze, bloda u.tml.); 2. Baseins; (ūdens) tvertne; aizgūts no vācu Becken;

beserêt .. Ārstēt; labot aizgūts no vācu bessern;

${ }^{19}$ Laumane B. Zivju nosaukumi latviešu valodā. R., 1973, 72.lpp. 


\section{binzuole, bindzuole Saistzole aizgūts no vācu Bindsohle;}

birnis Bumbierābele; bumbierābols aizgūts no vācu Birne;

borka Koka miza .. aizgūts no vācu Borke;

bindêt Saitēt aizgūts no vācu binden;

bintêt Saitēt aizgūts ar slāvu valodu starpniecỉbu no vācu binden (šeit salīdzinājumam minēts arī krievu бинmoвumb, baltkrievu бінтовацъ);

bobuškas Bakas aizgūts no krievu izlokšṇu бобуuкu (ar to pašu nozīmi);

bociki 1. Saišu zābaki 2. Kurpītes (Aconitum) aizgūts no baltkrievu izlokšnu бouiкi (ar analogu nozīmes attīstību);

boika Sviesta kulamā muca, kēerne aizgūts no krievu izlokšṇu бойкa vai baltkrievu izlokšnu бoŭкa (ar to pašu nozīmi);

boja; bojs Flanelis Aizgūts; seko salīdzinājums ar lietuviešu bajus, polu baja, baltkrievu $6 a \breve{\text {; }}$

botva Vārītas, ieskābētas, sasmalcinātas bietes, retāk kāli; ēdiens no šiem dārzeṇiem aizgūts no krievu Gomøa '(saknaugu) lapas; laksti' vai baltkrievu 6amea.

Runājot par vārda cilmes skaidrojumu īpatnībām izlokšņu vārdnīcās salīdzinājumā ar vispārējām etimologiiskajām vārdnīcām, ir jāṇem vērā tie faktori, kas saistīti ar izlokšṇu mutvārdu komunikācijas formu. Tā kā jaunu leksēmu parādīšanās (aizgūšana) izlokšṇu pārstāvju valodā bieži notiek vai ir notikusi mutvārdu formā, tad te zināma loma var būt arī cilvēku psiholoǵiskajām un fiziskajām īpatnībām (piemēram, kāda vārda izrunas neprecīzam uztvērumam), vārdu individuāliem lietojumiem u.c. faktoriem. $\operatorname{Lindz}$ ar to vārdu cilmes skaidrojumos bez tīri lingvistiskiem vispārpieñemtiem kritērijiem fonētiskās atbilsmes un vārda skaniskā sastāva attīstības likumiem, kā arī morfoloğiskajiem kritērijjiem izlokšṇu vārdnīcās vairāk nākas saskarties ar tautas etimologiju un vārda motivācijas meklējumiem svešvārdiem un 
mazākpaz̄istamiem vārdiem, dažādiem kontaminācijas gadījumiem, analoǵiju, arī individuãliem lietojumiem u.c. parādībām, kas izloksnēs (atšķirībā no normētas valodas) ir daudz biežãk sastopamas.

Vārda motivācijas meklējumi, cenšanās svešāku vārdu (vai vārda da|u) pielīdzināt paz̄̄stamam, zināmam vărdam izloksnēs parasti noris ar tautas etimologijas starpniecību. Tā, piemēram, Sinoles izloksnē ir registrēti zābaku nosaukumi šķirgati un ķirzaki $i^{21}$ (bii zàabaki, sàuce pàr ķirzakiem, pàr škirgatiem tùos vòlkàja viênu làiku briesmîgi). Vārda pamatā ir ādas aizstājēja nosaukums kirza, kas uz fonētiskas līdzības pamata pielīdzinăts izloksnē pazīstamiem vārdiem - dz̄ivnieku nosaukumiem ķirzaka un škirgata, tādējādi izveidojot gandrīz homonīmas formas. Te vērojama tendence radīt motivāciju nosaukumam, un tautas fantāzija šajos gadijjumos var iet visdažādākajos virzienos.

Arī Zemgales izloksnēs registrētais nevārīta maizes ēdiena nosaukums sidarbiksis un tā varianti siderbiksis, siderbikse, arī sudrabbisīte, sudrabbisītis u.c. kvalificējami kā tautetimologiski pārveidojumi no tâs pašas reãlijas apzīmèjuma sigapiksis, kura pamatā savukārt varētu būt igauṇu siga 'cūka' un ME III 213 II piksa 'biezs (sevišḳi cūku) èdiens' (?); šos vārdus sīkāk analizējusi B.Bušmane rakstā par maizes èdienu nosaukumiem ${ }^{21}$ Nereti dažāou leksēmu pamatā var būt arī toponīmu vai to sakṇu pārveidojumi un atvasinājumi. Piemēram, daudzās Vidzemes sēliskajās izloksnēs - Praulienā, Mētrienā, Mēdzūlā, arī Lizumāā, Sinolēe, Adulienā u.c. - ir registrēts ābola - sīpoliṇa - nosaukums boršs ar daudziem variantiem boršiňs, borštiňs, boršitis, borškīns, buorštinšs (bòršiñi mö́zi ziêmas ábuêlt'iņi bòršus kärre pie eglítẹs) un arī šĩs šḳirnes ābeles nosaukums boršiṇa (bòršinài pilli z'ä́ri ábúolu). Vārda pamatā ir ābolu šķirnes nosaukums vācu valodā Borsdorfer (Borsdorfer 'eine

\footnotetext{
${ }^{20}$ Putninga $M$. Sinoles izloksnes apraksts. R., 1983, 29. Ipp.

${ }^{21}$ Bušmane $B$. Nevārītu maizes èdienu nosaukumi latviešu valodas izloksnēs. - Dialektālās leksikas jautājumi II. R., 1986, 48.-50. lpp.
} 
Apfelsorte' Wahrig 739; sal. arī vācu toponīmu Borsdorf ${ }^{22}$ ), no kura tad tālāk ir izveidojušies visi iepriekš minētie šī ābola nosaukuma varianti.

Atsevišḳos gadījumos ar tautas etimologiju šḳietami var sasaukties arī izlokšṇu pārmaiṇu izraisītās sekas, it ĩpaši tad, kad vārdā vērojami ne tikai kāda viena, bet vairāku fonētisko pārmaiṇu rezultāti un vārds fonētiski ievērojami atšḳiras no sākotnējā. Piemēram, dažās Ziemelvidzemes izloksnēs ir registrēts auga - strutenes - nosaukums trusene, kam, domājams, sākotnēji nav asociatīva sakara ar dzīvnieka nosaukumu, bet analogā forma radusies vairāku fonētisku izmaiṇu rezultātā - ar $s$ skaṇas atmetumu vārda sākumā (šāda parādība attiecīgajās izloksnēs ir sastopama) un disimilāciju (strutene trutene trusene). Norādes uz šīm fonētiskām izmaiṇām arī ietilpināmas cilmes norāžu sastāvā.

Skaidrojot dialektālo vārdu cilmi, nākas saskarties arī ar analogiju, kad vairāki cilmes ziṇā atšḳirīgi vārdi tiek satuvināti vai vienādoti uz zināmas asociatīvas skaniskas līdzības pamata. Tā, piemēram, galvenokārt lībiskajās izloksnēs ragavu balzeņa apzīmēšanai tiek lietots atbilstošā literărās valodas vạarda balzenis variants balzuons (miêtns iêkš sliêcem iêliêk iêkša un ta liêk bấzon̂s vî́sa Vainižos), kuram, domājams, pēc analoǵijas ir pielīdzināts arī puḳes balzamīnes nosaukums (balzuona puķe jou ir istabas pukse, dârza balzuoni ar ir Pālē; balzonim i skat̃st. krüzẹn rõza ziêd Jeros) un, iespējams, arī alkoholiska dzēriena balzāma apzīmējums balzuons (bấlzô̂c slî̂nnekam labakeš zâl Vainižos).

Rakstā vārdu cilmes norāžu izveide un tās specifika dialektālajās vārdnīcās ir tikai ieskicēta; tālākajā darba gaitā nepieciešams šim jautājumam pievērsties detalizētāk un izveidot

${ }^{22}$ Rudolph $H$. Vollständigstes geographisch-topographisch-statistisches Orts-Lexikon von Deutschland... Leipzig, 1870. - Bd. I - II. 
zināmu sistēmu norāžu atspogu|ojumā, kaut arī šĩ tipa vārdnīcās biežāk nekā citās nākas saskarties ar dažādām neregularitātes izpausmēm, kas var traucēt konsekventu sistēmas realizāciju škirk|a struktūrā.

Šķirklı paraugi.

beķene; beķens subst. 1. Vecs, neglīts trauks (piemēram, krūze, bloda). prostu blùodu sàuce pàr bekeni. tầus sacija: kùo $t^{0} a ̂ d u$ bekseni liec uz gol̂da Sinolē; kùo t’âdu bekanu, vacu krùzi, liki uz golda? tèice, ka krùzèi biị voi $k^{0} a ̂ c$ rùops iesisc vòi Sinolē.

2. Neliela, padzi|inājumā izveidota (ūdens) tvertne, baseins. batistiêm [baptistiem] visu cilệku vaîg pakristît upê pagrem̃dêja zề ûdena. taga $i$ tâc beken̂s - tâda bedre iêtaũsîta ar ûdeni, tur iêkâp liêli un vẹci cil̂̀̂ệki Gaviezē.

3. Slikts, nepatîkams cilvēks. stàvi nu miêrâ, beķene! tas lomu $v^{o}$ ärc ir Sinolē.

Aizgūts; sal. vācu Becken.

belêt; belit v. 1. Balsināt; kalķot. kotru godu pavasarâ b'el'eju kukn'i. b'el'iêju àr gl'èizdu Kalupē; s'înas bel'iêt ài [ar] krèitu Baltinavā; pavasar'e b'el'ei uôbul'n'èicys Livānos; arī Lỉksnā, Nīcgalē, Vārkavā.

2. Aizdarīt ar pienu, krējumu; darìt baltu, pievienojot pienu, krējumu. putru b'el'èja ài p'ìnu Baltinavā; putru v'âl b'el'àjäà ài soldonù k'riejumu - àizvùor'à ài p'ìnu, ka âd'ä, dal'âa kr'ìejuma Nautrēnos; Letyjâ piktin'î putru âd'ä nabalâtu Mērdzenē.

Sal. krievu белить 'заправлять пипц молоком, сметаной' ПОС I 161.

Aizgūts; sk. Reḳēna 1975, 124 (< krievu белить, baltkrievu бяліць, polu bielić). 
beñdele; beñdelis; beñde subst. 1. Šḳērskoks, kas savieno un satur celtnes divas pretējās spãres. bendele - škș̣̂rskuoks, kas jumtu späres satur kuopā Valmieras apkārtnē; beñdếls sasiên spärs kuōpa vidu pär Vainižos; tie ì bèndeli, kas zàm jùnta f âdi stipruma škè̀rśi salikti nùo spàres uz spàri Sinolē; bèndeles bàlksi nù vînas spàres uz ùtru, lài spàres napleśâs Kalncempjos; citreĩz divas beñds stấpas uzlik pẹls, citas akal salms Jeros; bendele ar̄i Aiviekstē, Bauṇos, Braslavā, İvandē, Kārḳos, Kūdumā, Limbažos, Mazsalacā, Mežotnē, Naukšēnos, Nītaurē, Pālè, Rencēnos, Svētciemā, Vecatē, Vilzēnos; beñdele ME I 279; EH I 212 Vecpiebalgā, Ungurmuižă, Praulienā, Rankā, Lielsalacā, Trikātā; beñdele EIV I 161.

2. ME I 279 die Schicht, die Abteilung des Heues od. Getreides, gew, panta genannt (siena vai labības kārta, slānis, da|a, parasti saukts panta); EH 1212 Livibèrzēe, Džūkstē (Džūkstē ari malkas b.).

3. EH I 212 bendeles (pl.t. ?) "kuoki pie arkla .., pie kuriem piesien dzenaukšas" Tirzā.

Aizgūts; sk. ME I 279 (anscheinend aus mnd. bendel "Binde").

bendzit; bendzēt v. Neskaidri, nesaprotami runāt; runāt svešā, nesaprotamā valodā. navàr sa:prast, kù tur bèndzej Dignājā; ben'dzej kr'ivysku Aknīstē.

EH 1212 bèndzît ${ }^{2}$ Liezērē, Aknīstē.

Aizgūts; sal. baltkrievu dial. бендзкаациа 'rieties' Слоўнік 1181.

biestapiēns; biestpiēns subst. Jaunpiens. tuõ piênu, kuô pir̂rmuôreĩz slậc pêc atnešanâs, saûc pâ̂r biēstapiēnu, jaûnpiẽnu Grobin̄ā; biêstpiẽns Nīkrācè; arī Vērgalē.

Hibrīdleksēma; sal. vācu Biestmilch; sk. Bušmane, 1996, 11. 
billa; bille subst. 1. Raudulīgs cilvēks (parasti bērns); raudulis. tã billâsana i raûdâsana. mès paši cic citàm tâ sacijãm

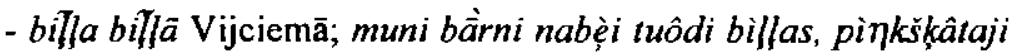
Alūksnē; càuru nakti tis mozis billla billlàja Alsvikos; riktiks čiga tas ir, ir gan bille riktîks, kas tâ raûd viên mệ̀r un vis Ilzenē; bill $a$ arī Sinolē; ME I 296 billla Liepupē; sk. arī pilla.

2. dsk. Raudas. ka bà̀rnis raûdàja, ta sacija - nu jòu atkàl billlas vala Sinolē; meîtene laîda billlas vaḷâ, vusa ustaba skaneja Zeltinos; billlas arī Alūksnē, Annā, Vecatē, Ziemeros; ME I 296.

Par cilmi: ME I 296 (wenn altererbt, wohl aus *bilna, und in dem Fall zu bàlss, an. belja "brüllen", schwed. dial bjäla "jammern, weinen" u.a.). Rage 1970, 140-147 (saista ar Baltijas somu valodu ietekmi, ig. pill, somu pilli 'mūzikas instruments', arī 'raudas; raudulis', ig. pillima 'raudāt' u.c.).

'bizūteris subst. Piesēdētājs. bizūteris - piesệdẹțājs varbüt tiesā vai kādā sanāksmē Valmieras apkārtnē.

EH I 222 bizîteris: PS kennt ein auf mnd. bisitter beruhendes bizīteris 'Beisitzer (beim Gericht)'; (prof. P.Šmits (no Raunas) pazīst uz vlv. bisitter balstītu vārdu bizīteris 'piesēdētājs (tiesā)').

Aizgūts; sk. arī Sehwers 1918, 143 (mnd. bisitter); sal. vācu Beisitzer.

"bizüeris; biz̄̄ers subst. Kustīgs, veikls cilvēks (arī dzìvnieks), kas ātri iet, daudz skrien u.tml. skraida kā bizìters

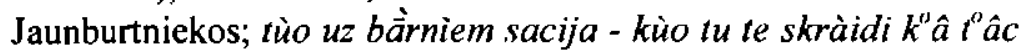
bizitèrs, $k^{o} a ̂$ skràideklis Sinolê; vaî tu seîdes miêra vâ̂ ne! skraĩd ka bizītêrs! Vainižos; bizīteris - apkārt staigulis, cilvệkam nav miera, darba nav, nezin, kur laiku kavēt, staigā apkärt pa 
nāburgiem plāpādams Valmieras apkārtnē; skatîs, lilis bizîters [bullis] atsprucs valâ un bizuô kuô troks Alūksnē.

EH I 222 ar "?": kuo tu te skraidi kâ b. (d.h. sehr schnell) Ķieg̀elos, Mazsalacā, Smiltenē, Trikātā, Valmiermuižā; bizĩteris; bizīters ËIV I 174.

lespējams, veidojies bizuot ietekmē.

blazdarēties; blazderēties v. Pavadīt laiku bezdarbībā, slinkot; klainot, staigāt apkārt; arī blēṇoties, palaidṇoties. puīka sâcis blazdarêtiês, tapêc nuô skuōlas padzîc Bauskā; kad es te atnăcu, vin̂š jau blazdarejâs bez dârba lecavā; kuô tu blazdarejies apkärt! gãajis dârbâ, lâ̂ mãtê̂ viêglâk! Bauskã; blazdar̂s ir tâc cilvệks, kas nau nuôteîkc savâ gimenê, blazdarejas nuô viêna piê uõtra lecavā.

Aizgūts; sal. lietuviešu blazdarinéti 'klīst bez darba, dīkā, klaiņot' LKŽ I 894.

Sk. arī blezderēties.

blazdars; blazders subst. Cilvēks, kas mēdz pavadīt laiku bezdarbībā, slinkot, klainnot, staigāt apkārt; arī nenopietns, vieglprätīgs cilvēks. blezdêrs, blazdếs - saka uz jaûnu cillệku, ka viņ̧š nestrâdâ un ka [viṇam ir] visâdas sliktas îpašîbas lecavā; Düminu puĩka tâc blazdar̂s, negrib mâcîtiês, tik blañâs apkārt Bauskā; blazdârs tas bii tâc slin̄kis, kas sliñkuô lecavā; blazder̂s ir nenuôpiêtns cil̂रệks Bauskā.

Aizgūts; sal. lietuviešu blāzdaras 'nemierīgs, skraidīgs cilvēks' LKŽ I 894.

blicis subst. Plicis (Blicca bjoerkna). näbû̀rg poîss a vakâr vis diên doũdzijas pa up ấ pikšer [makšḳeri] - mazuos blicišs lât bi dabūšs Ternejā; tepat diki joû vaîg bût kâdî̀ bličim ấ, vaîg tik palükat viên Lodē; blics tok i viên trakuôt peīn ziŭ, es tuös cits [citas zivis] ne 'maz tâ negrib Rūjienā; arī Plaviṇās. 
EH I 229 Talsos; ar skaṇu miju < plicis, sk. Laumane 1973, 183.

blūds subst. 1. Klaiṇotājs; klaidonis. ak tu, vacàis blùc, kùr tu b'eji? Livānos; M'ijài [personvārds] na v'èirs - stàigoi k'êt blùc nu v'îna pakša da ùtra [no vienām mājām uz citām], kap kùr k'eîdu òls las'i nùgìiut' Rēznā; arī Pildā, Maltā.

2. Vadātājs. blùd'i vàr dasas'it' [piesiet], $i$ nat'iks nu m'eža ùorâ Prei|os; pa myûsu kryûm îm blùc vodoi Šk Şilbēnos; jû suôka blùds voduôt', vusu nakt'i atvodova Baltinavā; isalaîzu $\hat{t}^{\prime}$ da sàtài, dasasyta blùc i nùv'ed'ä da patmal'is' navàr dasadùmuôt', kùr ît' dagùoju p'i Gabrava, c'iert'a gaîl'i d'zîduôt Kalupē; Zos'i [personvārds] blùds vodùo pa pùru Pildā.

Sal. krievu блудuть 'блуждать, плутать' СРЯ I 116, блудня 'тот, кто блудит' СРЯ 1116.

bobuškas subst. Bakas. ka gul'à ar bobuškòm s'enôkk, slymùo, vusa mutä [seja] àr dùb'à̀m patyka Nautrēnos; bà̀rn'îm šud'ìn' išk'ầl'à [iepotēja] bobuškys Mērdzenē.

Aizgūts; sal. krievu izlokšṇu бобушки 1. Оспа, оспеннье пятна'; 2. 'корь' СРНГ III 39.

bociki subst. 1. Saišu zãbaki. boc'iks šyva nu uôdys, ar ji gùo gùdûs, kotru d'ìn jàu nanosùo Galēnos; s'äu zùobokus p'ierka i bocikus maîtòm Nautrēnos; nùp'iêrc, tàv, Jùon'išàm t'iergâ jaunûs boc'ikus Baltinavā; arī Maltā, Mērdzenēe.

2. Kurpītes (Aconitum). boc'iki jir tùos pošys kùrp'eît'is' mỳusu boc'ik'i z'îd'ie t'ìms'ìm i gaišy z'il'im z'îd'ìm Kalupē.

Aizgūts; sal. baltkrievu боцiкi 1. 'ботинки'; 2. 'сапожки'; 3. 'бот. борец синий'

boika subst. Mucai līdzīgs koka trauks sviesta kulšanai; sviesta ku|amā muca, ḳērne. [sviestu] s'enôik n'eja [kūla] ài l'iz'eîku mùola blùdâ, vâlô̂k bòikâ Nautrēnos; k'riejumu sajâ 
kùka bòikâ, iłyka krystenus, izlyka vuôku, càr kurù b'eja probuôsc kùks, i n'eja Pildā; bòikâ sal'ài skuôbu k'r'iejumu i n'èi t'ik il'g'i, kolč s'v'tsc gotòus. bòikys vysod jir nu kùka tàis'eîtys Preilos; s'v'ista bòikài vuôks v'îersâ, càr bòikys vuôku izgr'îsc opòls càurùms, càr càurumu izbuôsc kr'ist'ènc. cyllava tù krist'eñu i sasasytuôs s'v'šsc Kalupē (Rek̄ēna 1975, 233); àr bòiku vàr ùotr'i san'êit' [sakult] s'vîkstu Dricēnos; arī Asūnē, Bebrenē, Istrā, Ozolainē, Rēznā; sk. karti.

Aizgūts; sal. krievu izlokšņu бойкa 'простого устройства аппарат для сбивания масла' СРНГ III 66, baltkrievu бойка (для сбивания масла) 'маслобойка, пахталка'

boršina; boršinšs subst. Sīpoliņš (äbele). dôrzá bija viéna bòršina. bòršinài pilli z'ấri ábuólu Mēdzūlā; bòršina jàu ziéd. bòršinàm smu:ki, iesórkä́ni ziédi Mēdzūlā.

Sk. boršs.

boršs; boršinš; boř̌tinyš; boršñtis subst. 1. Ziemas ābols; sīpoliṇš. bòršus kä rẹe pie eglítes Mēdzūlā; bòršiņi na:vaid lili -

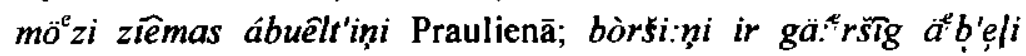

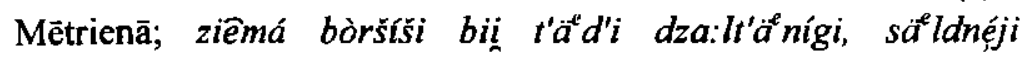
Mēdzūlā; bòrštinšs Lizumā.

2. Sīpoliṇš (ābele). bòršini bii vòi ko:trá dầrzá Mēdzūlā.

Pārveidojums no ābolu šķirnes nosaukuma (sal. vācu Borsdorfer).

Sk. arī borškīns, buorstiňš.

borda; borde; bords subst. I. Svītra vai ornamentēta josla (uz sienas), kas norobežo griestu un sienu krāsojumu. agrâk jou taĩsij strĩp [istabas sienām] un ta tâdus raibumus. tuõ [svītru] soûc pa bor̃du Pālē; bốda i, ku pabeidzas siênas krãsuôjums un sâkas griêstu krãsuôjums, ta tur nuôvệlk strïpu un tuõ saûc pa bor̂rdu Kursǐšos; bor̂da ir rùbežlinija stầp gristîm un sinas 
krùosajumu Ziemeros; kad per̃vei istab, tad oûkšmala lik tâds bor̃ds Vainižos; arī Aiviekstē, Dignājāa, Kalncempjos, Krimuldā, Svētciemā, Valmieras apkārtnē. // Apmale; līste. luôg sleñgim gar mal lik bor̂d, tâd tụ̂s̆ak tuō per̃vei Jeros; borda liste istabās, kas nuoslệdz sienas, griestu un grìdas dēlu galus Valmieras apkārtnē; $k a$ nuôbeîdz [laivu gatavot], $t a$ nãk tâda lakta [lata] likka apkârt laīvâ̂. tuỗ saûc buōrda, bô̂rc. bồdâ blakus dullis Nīcā.

2. Svītra, ornamentēta josla (apgèēba gabalam, tekstīlijai). ieaûdîs bòrdu [šallei malās], ta tùr toâdu sovâdâku ieâuż, ta t"à ir bòrda. bòrdas [ir arī] ap brùnçiem ap apukšas molu Sinolē; [lakatam] viducs brüns, gar moläm bòrdes Sinolē; aûda šuōtelu aûdumu, tâdu bor̃du ieaûda iekšãa, strīpu Kārḳos. // Apmale; lente, aukla (parasti apgēerba gabala malās). gar mal šuõtelam tâd citâdak bañt, tã biị bor̃d. apužbruñ்̃i a biị a bor̃dem, citadak bañt apuža, ka paš apužbruñč Jeros; [priekšautam] tâda bor̂tîte, liēla, plata leñta, kuô sasiêt lecavā; bor̃da tok i klẽ̃tam, kuo šuv gar apkakli, gar ruôkam Mazsalacā; sièveš cẹpurem bi bor̃d gar mal, tâc ka strikic Jeros; gar malu nuôšuva bốdi. lai smukâk Zaleniekos; arī Aiviekste, Dignājāa, Valmieras apkārtnē.

3. Auduma krokojums, savilkums (piemēram, ap kaklu, piedurknēm); volāns. brüts kleĩts jou taũsij tikai lidz zemi, bỡds bij ap kakl un us krûtim savilkts Idū; [kleitām] liek tâdas zìda falberes apužâ, lai žvĩkst. falberes ievil̂ktas, tâda bor̃da Pālē;

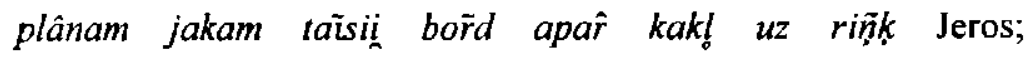
[apakšsvārkiem] platã bor̃da apakšā, bruñči stâvẽja tik kupli. tagad saka volāni, mẽs jàu sàucäm pa bor̃dām Burtniekos.

Aizgūts; sal. vācu Bordüre, Borte.

borka subst. 1. Koka miza. stutmalk: saciêrt nuo priēž un êgl kuôk'ẹm. stutmalk: bork'ẹ a bô̂k:dzêlz, bork:s tur pat 
sadedzn'e Puzē; bork:s vien i palikuš, malk: i aizvest Popē; arî Dundagā.

2. Riks, instruments kokmateriālu mizošanai. a bork borkẹ stutmalk Dundagā.

Aịzūts; sal. vācu Borke.

borkdzelzis; borkdzelzs subst. Riks, instruments kokmateriālu mizošanai. jāuztrin borkdzelzis - palicis pa visam truls Piltenē; a borkdzệlz bi janoborke stutmalke mîz nuoste, le ilgak kalpe Dundagā; stutmalk: bốk'e a bốk:dzêlz Puzē; a borkdzêlz nuoborka balks:s Popē; borkdzelziš Kuldīgā.

Hibrīdleksēma; sal. vācu Borkeisen.

borska subst. Liels koka āmurs. bô̂sk taîs katra mäja bümañ no balks rezgal, vis vaïrak no priēż kuôk Jeros; nem nu tuō bor̂sk un vaza [sit] vir̂su balksam Jeros; bòrska vài bùrska, kùo gùovìm mìefinus sit. kùoka klucis, sãnuôs ìelikc kâc Ērg̉emë; tùo kùoka ềmuri sàuc pa bòrsku. ka a ciri sit, ta mietìm gali plîst pušu, bet ka a tùo kùoka ểmuri sit, ta neplist. pañèm tùo bòrsku ùn àizèi iesit mietu! Rencēnos.

Aizgūts; sal. lv. *barske, vācu Barte.

Sal. arī borsts, burska.

Brañči, vsk. Brañcis subst. Noteikta kalendāra diena (Labrenča diena), kad tiek rïkots gadatirgus. tîrgus büdas Baüskâ sacêla tik [tad], kad bij gadatirgus - uz Vastlājiêm un̂ Brañčiem Bauskā; Vastaläja tîrgus un̂ Brañči nuôtika katru gadu. māte Brañču tîrgû man̂ nuôpirka mutes ệ̂nũnikas Bauskā.

Personvārda Labrencis pārveidojums. 
brede; brede subst. 1. Bedre. met karpels iêkša brede un zems virsu Jeros; briësmigi agrak bij sniêga käpas, te bij tâdas bredes Mazsalacā; Pẽter, nac nu prâtig. te i bred Rozēnos; us cela brede piê bredes Vecaté; vai tu redzeị a, ka vilks iêgā́s akal brede! Jeros; arī Alojā, Idū, Ipiḳos, Katvaros, Konosos, Lodē, Pociemā, Rūjienā, Skaṇkalnē, Ternejā; ME I 329 Rūjienā, Mazsalacā; EH I 240 arī Valkā.

2. Kaps. akminc apš galvas, un visi tâ pat bûs tamî bredê Mazsalacā.

Ar metatēzi $<$ bedre.

breksis subst. Plaudis (Abramis brama). Cepšu ẹzàrs, liēlc ẹzàrs, tùr jàu agrâk bija zivis. gal̂lvenàis lidakas, asari, brekši. brekši jàu laba zive Kārḳos; Bur̃tniēku ẹzẹrà brekši i tâdi trệkni, biezi, Gaüjā tâdi asakaîni Lugažos; breksis i lìdzîks raûdaî, biškît tâc savâdâks, savâdâkas zvĩnas Kursīšos; ka breks noguld pludin. ta i japiêcệrt un jovẹlk Laucienā; vînu zimu izvilkâm devini tònnu brekšu Alūksnē (Laumane 1973, 164); brekši tuôdys z'ìus' Dàlgavâ. brekšy - opol'is, pal'el'is i palâkys z'ius' Kalupē. brekse, breksis, brēkša, brekškis; breksme; breksne, breksnis. Šie nosaukumi sastopami galvenokārt Kurzemē, Vidzemēe, reti Latgalē; Laumane 1973, 164 - 166; LLVV 11 117, ËIV I 184.

Aizgūts; sal. vācu dial. Bräkse (Brechsen), sk. Laumane $1973,166$.

buõkât; buõkêt v. 1. Kuḷot, dauzot u.tml. dalīt nost (akotus miežiem); kult (graudus otrreiz), lai nodalītu akotus. tầus cik rèižu tèice: bùokâsèm nu miežus! ka viniem bị akùoti kl'âtu, ta vinus ar v'àlẹm - ar spruguliem piedar̂âa vệ dàuzija, lài nùoiêt nuôstu tie okùoti. tùo sàuce par bùokâšanu Sinolē; miêžs akal bi jâbuōka. piëdraba, kad iskūl miêžs, sabẽr kluöna un a rull pa vir̂s, kamet zir̂ks putas. nuôdoũzii akuôts nuôst Vainižos; ja grib 
miêžim dabut akots un sệnal̂́s nuô, tuôs izvẽti, tad isklậ zeme piẽdraba uz rin̄k un a tuō paš rull un zîrg buōkse Svētciemā // Ar vāli, spriguli kult. pät':e aúdzệî sệklẹniekus, pät':ẹ bùokâịiu; sàklas mún po:šåă Kusā; tås goluótnitess, kur sệklinas, kot sòusas, tad jàbùokà Ērglos; buōkât arī Sausnējā, Zaubē, Vaidavā; buôkêt Limbažos; ME I P|aviṇās; EH I 258 Rankā, (mit ùo $o^{2}$ Ërglos; EH 1258 buōķêt arī Saldū, Lielsalacā. Sk. arī būkât (1).

2. Svinēt apkūlības. da rị́ta bùokâià̀m - ệệm un dzẹr'ệm, ùn dòncuôjâm Kalsnavā; kuír jòu küle, tuír bùokâina. [pazina] gâi tik bùkâdàms, dza:rdams Bērzaunē. Sal. būkāt (3).

3. Ẽst (daudz, ar lielu apetīti). bùokà. ká ka bu:tu ri:ịu kûluši Viesienā; ếd'iet, pùikas, bùokajiet! Lazdonā; bùokà, ka lẹi plị́̂st! Kusā.

EH I 258 (mit ùo²) Bērzaunē; EH I 258 buôkêt Svitenē. Sk. arī buõkêties.

4. Sist; pērt. bùokà kà uôrmän'c' sounu zírrgu Liezērē.

ME I 361 buōkât Vecpiebalgā.

5. EH I 258 (getrocknete Wäsche) mit einem Bleuel glättend bleuen ((izžāvētu velu) ar vāli gludinot kult) Vecpiebalgā.

Aizgüts; sk. ME I 361 (Anscheinend aus mnd. boken "klopfen, schlagen").

burnass subst. Vatēts sieviešu ziemas mētelis vai pusmētelis. bùrnasu nosava vâlâ rud'in'iê i z'ìmâ Kalupē; a'pàl'c bùrnosu, tod aj ùorâ! Pildā; bùrnas: šyun nu pošàustuôs vodmotys Galēnos; arī Kārsavā, Maltā, Rēznā. cesnais burnass cieši piegulošs sieviešu ziemas mētelis. c'esnajìm bùrnas'ìm sagrîz'e is kroja muguru, bùrnass b'ie vys càuri da z'em'èi v'înuôc, p'akal'iê p'ilyka grùmbu. ap plac'ìm bùrnass b'ie bris'm'êk aps'tîpc .. bùrnasa p'idùorkn'is b'ie plotys Kalupē. 
// Vatēts vīriešu vadmalas pusmētelis. pùišìm b'ìe taîd'i vodmola pusm'iet'eli ar vatu iškâ - sàuc'ệm pàr bùrnas'ìm Tilžā.

Aizgūts; sk. Reḳēna 1975, 472 līdz ar liet. izl. bur̃nasas 'silts sieviešu ziemas mētelis' aizgūts no bkr. izl. бурнас, sal. kr. бурнус, po|u burnos $<\mathrm{fr}$. bournous < arābu burnus.

\section{SAIISINĀJUMI}

Bušmane 1996 Bušmane $B$. Aizguvumi piena produktu nosaukumos latviešu valodas izloksnēs. LZA Vēstis, 1996, $\mathrm{N}^{\circ} 2$.

EH - Endzelīns J., Hauzenberga E. Papildinājumi un labojumi K.Mīlenbaha Latviešu valodas vārdnīcai. I - II. R., 1934-1946.

ĖIV Kagaine E., Raǵe $S$. Ërg̀emes izloksnes vārdnīca. I - III. R. 1977-1983.

Laumane 1973 - Laumane $B$. Zivju nosaukumi latviešu valodā. R., 1973.

LEV - Karulis $K$. Latviešu etimologijjas vārỏnīca. I II. R., 1992.

LKŽ $\quad$ - Lietuvių kalbos žodynas. I - Vilnius, 1968-... LLVV - Latviešu literārās valodas vārdnīca. I - VIII. R., 1972-1996.

ME Milenbahs $K$. Latviešu valodas vārdnīca. Redig̉ējis, papildinājis, turpinãjis J. Endzelīns. I - IV R., 1923-1932.

Raǵe 1970 Pare C. О некоторых заимствованиях из эстонского языка в говорах Вицземе.

Взаймосвязи балтов и прибалтийских финнов. Рига, 1970, с. 135-155.

Reķēna 1975 - Reķēna A. Amatniecības leksika dažās Latgales dienvidu izloksnēs un tăs sakari ar atbilstošajiem nosaukumiem slāvu valodãs. R., 1975. 
Sehwers 1918 Sehwers $J$. Die deutschen Lehnwörter im Lettischen. Zürich, 1918.

Wahrig Wahrig G. Deutsches Wörterbuch: Mit einem "Lexicon der deutschen Sprachlehre" München, 1980.

поС

Слоўнік Слоўнік беларускіх гаворак паўночна-

Псковский областной словарь. I Ленинград, $1967-\ldots$ заходняй Беларусі і яе пагранічча. I Мінск, 1979 -

СРНГ Словарь русских народных говоров. I Москва- Ленинград, 1965 -

СРЯ Словарь русского языка. I IV Москва, 1981-1984 (2).

\section{ANGABEN ZUR HERKUNFT DER WÖRTER IN DIALEKTALEN WÖRTERBÜCHERN Zusammenfassung}

Das im Beitrag erörterte Thema betrefflich der etymologischen Angaben in Mundartwörterbüchern steht mit einer der künftigen Aufgaben der lettischen dialektalen Lexikographie der Erstellung des neuen vereinten "Wörterbuchs der lettischen Mundarten" in Verbindung. Dieses Wörterbuch wird bei Stützung auf Traditionen der lettischen dialektalen Lexikographie als ein erklärendes Mundartwörterbuch gestaltet, das Elemente der Synchronie und Diachronie vereinen würde neben der Verknüpfung mit dem "Lettisch-deutschen Wörterbuch" von K.Mühlenbach sowie seinen "Ergänzungen " und kurzen Angaben zur Herkunft von Wörtern (diachronischer Aspekt) wird im synchronischen Aspekt versucht, die mundartliche Lexik in ein den heutigen Stand reflektierendes System einzufügen. 
An die Mundartwörterbücher können bei Herkunftsdeutungen nicht solche Ziele wie an spezielle etymologische Wörterbücher gestellt werden, denn ihre Aufgabe ist nicht die Widerspiegelung der Wortentwicklung bis auf die Ursprache (bzw. eine verwandte Sprachgruppe) nachzuvollziehen, indern man alle Lautwechsel und Gesetzmäßigkeiten von Entsprechungen verfolgt und die Verwandtschaft des Wortes mit den Wörtern derselben oder einer anderen Sprache feststellt. Daher bestehen Unterschiede zwischen Herkunftsdeutungen in dialektalen und etymologischen Wörterbüchern vorwiegend auf dem Niveau der Herkunftsrekonstruktion des betrefflichen Wortes. Die Aufgaben von Herkunftsangaben in Mundartwörterbüchern wären zum einen mit den Beziehungen und Unterschieden zwischen Mundarten und der Gesamtsprache (Literatursprache) zu verbinden resp. auf dem Niveau unterschiedlicher Systeme und Untersysteme einer Sprache zu betrachten, z.B. Verweise auf dialektale, durch Lautwechsel erwirkte Erscheinungen Metathese, Dissimilation, Elimination von Lauten u.dgl., Angaben zur Kontaminierung von Lauten oder Formen sowie weiteren Faktoren, die die Bildung des einen oder anderen dialektalen Lexemes beeinflusst haben.

Die nächste Stufe von Herkunftsangaben liegt auf dem zwischensprachlichen Niveau, sie betrifft die Relationen zu den Nachbarsprachen und ist an die Feststellung der Entlehnungsquelle oder aber die Ermittlung von Komponenten der Hybridlexeme gebunden. Auch die Konkretisierungsstufe der Entlehnungsquelle kann unterschiedlich sein sowohl ziemlich annähernd, nur mit Verweis auf diejenige Sprachgruppe, aus der die betreffliche Entlehnung stammt (Slavismus, Germanismus, Hybridform), als auch noch mehr verallgemeinert "fremdstämmiges Wort" (ähnlich wie in mehreren litauischen Mundartwörterbüchern). Im Falle differenzierten Zuganges ist die Entlehnungsquelle bereits konkretisiert, und die Angaben reflektieren ein konkretes Wort (bzw. konkrete Wörter), das (die) der Entlehnung zugrunde liegt (liegen) oder liegen 
könnte(n), wobei die Hauptaufmerksamkeit der zum Bestand der Gemeinsprache nicht gehörenden Schicht der peripherischen Lexik gilt.

Die Herkunftsangaben können sowohl ihrem Inhalt als auch ihrem Umfang nach recht unterschiedlich sein. Bei einem Teil der Wörter sind am Ende des Wörterbuchartikels Verweise auf eine veröffentlichte Quelle der etymologischen Information (ME, EH, LEV, LEW, eine dialektologische bzw. etymologische Forschung oder sonstige Veröffentlichung) gegeben, wo die Herkunft des betreffenden Wortes oder ihm verwandter Wörter eingehender betrachtet wird und der die Interessenten umfangreichere Daten über das zu behandelnde Problem entnehmen können. Solche konspektive Angaben (nur die Abkürzung der Informationsquelle beinhaltend) sind vor allem für allgemeingebräuchliche, in etymologischen Wörterbüchern erwähnte Wörter vorgesehen (z.B. durch solche Angaben können die ererbten Wörter charakterisiert werden). Die Herkunftsangaben können aber auch mehr detailliert sein, es können Fragmente von Forschungen zitiert werden, worin z.B. die Entlehnungsquelle angegeben oder weitere Information zur Geschichte des Wortes geboten wird.

In vielen Fällen müssen die Autoren des Wörterbuches die Herkunftsdeutung von Wörtern selbständig vormehmen. Zum eigentlichen Untersuchungsmaterial gehören hier vorwiegend dialektale Lexeme verschiedene lokale Entlehnungen, Zusammensetzungen, Hybridformen u.a. lexikalische Einheiten, die entweder in den letzten fünfzig Jahren fixiert sind oder aber gemäß den Prinzipien der Wortwahl in die bisher umfangreichste Sammlung der mundartlichen Lexik das "Lettisch-deutsche Wörterbuch" von K.Mühlenbach und seine "Ergänzungen nicht aufgenommen wurden, so dass ihre Herkunftsanalyse des öfteren erstmalig durchgeführt werden soll. Unter diesen Lexemen gibt es viele lokale Entlehnungen: in niederlettischen Mundarten Germanismen, im hochlettischen Dialekt 
Slavismen oder mittels slavischer Sprachen entlehnte Wörter (z.B. bekene ..; borka ..; bobuskka ..; boika ..).

Im Vergleich mit den allgemeinen etymologischen Wörterbüchern sind bei Betrachtung der Eigenart von Herkunftsdeutungen in Mundartwörterbüchern solche Faktoren in Betracht zu ziehen, die an die mündliche Kommunikationsform der Mundarten gebunden sind. Da die Erscheinung (Entlehnung) neuer Lexeme in der Rede von Mundartträgern häufig in der mündlichen Form erfolgt oder erfolgt ist, so können hierbei auch psychologische und physische Eigentümlichkeiten der Menschen (z.B., ungenaue Auffassung der Aussprache von Wörtern), individueller Wortgebrauch u.ä. Faktoren eine gewisse Rolle spielen. Somit stößt man bei Herkunftsdeutungen von Wörtern außer rein linguistischen, allgemeingültigen Kriterien den Gesetzen der phonetischen Entsprechung und der Entwicklung des Lautbestandes von Wörtern in Mundartwörterbüchern mehr auf die Volksetymologie und Motivationsversuche für Fremdwörter und weniger bekannte Wörter, verschiedene Fälle der Kontaminierung, Analogie sowie individuellen Gebrauch u.a. Erscheinungen, die in Mundarten (im Unterschied von der normierten Sprache) viel häufiger vorkommen. 


\section{Agris TIMUŠKA \\ LEKSIKOGRĀFISKAS PĀRDOMAS PAR DIALEKTĀLĀS FRAZEOLOĢIJAS VARIABILITĀTI}

Izlokšṇu leksikas, bet jo ipaši frazeologismu variantu daudzveidība un tās adekvāta leksikogrāfiskā atveide ir viens no aktuālākajiem leksikogrāfijas teorijas jautājumiem. Par frazeologismu klāsta daudzveidību varam pārliecināties itin apjomīgajās dažādu valodu frazeologismu vārdnīcās, tostarp arī ne pārāk sen izdotajā "Latviešu frazeologijas vārdnīcā" Toties fiksētais valodas materiāls parasti kvantitatīvā ziṇā ievērojami pārsniedz vārdnīcā ietverto, tādē] īpaši aktuāla ir autoruprāt "issto", reprezentatīvāko un semantiski visvairāk relevanto frazeologismu variantu atlase un leksikogrāfiskais atspogu|ojums. Mazāk būtiska minētā problēma ir literārās valodas vārdnīcu izveidē, turpretī, sastādot kādas valodas visu izlokšnu vărdnīcas, piemēram, "Latviešu izlokšṇu vārdnīcu", praksē ar to nākas saskarties visai bieži. Š̀i šḳietami tehniskā jautājuma veiksmigs risinājums lauj apjaust valodas elementu sistēmu tās pilnskanībā, savukārt optimāla atspogu|ojamo variantu atlase, palielinot autoru darba apjomu, vairo topošās vārdnīcas draudzīgumu lietotājam.

leskatam sīkäk raksturoti galvenie, visvairăk izplatītie dialektālo frazeoloǵismu variantu veidi:

1. fonētiskie varianti (FV). "Latviešu izlokšnu vārdnīcā", frazeologismu skaidrojumu sakarā priekšplānă izvirzot semantikas atspogu|ojumu, nav tik būtiski uzrādīt viena frazeoloǵisma fonētiskās atšḳirības dažādās izlokšṇu grupās. Tātad par pilnīgi apmierinošu uzskatāms risinăjums - šksirklī kā ilustratīvo materiālu dot vienu FV no katras lielākās izlokšṇu grupas, bet skaidrojumā tos apvienot, piemēram, šķirklī braukt: frazeologiska rakstura vārdu savienojumus $\square$ bràukt ${ }^{2}$ pèlnâa $\hat{a}^{2}$ Dignājā; $\square$ braûkt ${ }^{2}$ pelññas ${ }^{2}$ Vainižos un 


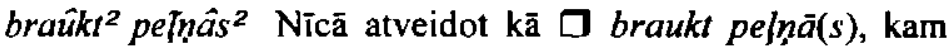
seko skaidrojums, proti: [strādāt papilddarbu, kas saistīts ar kā pārvadāšanu].

2. morfologiskie varianti (MV). Arī šie frazeologismu veidi semantikas atklāsmē nav pārāk relevanti, zināmas problēmas rada vienīgi daudzo frazeologiska rakstura vārdu savienojumu grupējums. Piemēram, s.v. ak būtu dodami vairāki izloksnēs fiksētie MV ar interjekcijas $a k$ un lietvārda diena deminutīva vokatīva formas variantu kombināciju:

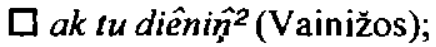

$\square$ ak tu mana diêniñ ${ }^{2}$ (Vainižos);

$\square$ ak manu dienin (Pālē);

$\square$ ak mîžza $a^{2}$ diêninga ${ }^{2}$ ! (Nīcā);

$\square$ ak tu manu diêning ${ }^{2}$ (Kursīšos);

$\square$ ak tu ma(:)n diêniñ ${ }^{2}$ (Popē);

$\square$ ak tu mīla diêniņa ${ }^{2}$ ! (Kursīšos);

$\square$ ak tu mīlu diêning ${ }^{2}$ ! (turpat);

$\square$ ak iu dieñ ${ }^{2}$ ! (Bebrenē);

$\square$ ak tu dienināas ${ }^{2}$ ! (Bruknā).

Acīmredzot no nule minētajiem 10 frazeologisma morfologiskajiem (un morfolog̀iski leksiskajiem) variantiem šķirklī atspogulojamas vismaz 5 nosacītas morfologiskās ligzdas: $\square$ ak tu (mana) dienin, $\square$ ak (tu) manu dienin(u), $\square$ ak tu mil a dieninga (ar $\overline{1}$ mìlu dieninu $), \square$ ak müžza dienina, $\square$ ak $t u$ dienināos (arī dien) ar vienu, kopīgu nozīmes skaidrojumu: [lieto, lai paustu dažādas jūtas un/vai izteiktu emocionāli intelektuālu attieksmi].

3. sintaktiskie varianti (SiV). Tie tradicionäli tiek uzskatīti par visai atšķirīgiem tieši savas sintaktiskās konstrukcijas

Par izlokšnu leksikas morfologisko variantu atspogulojumu "LIV" škirklos skat. arī Jansone I. Varianti izlokṣṇu vārdnīcās: problēmas un risinājumi. // Linguistica Lettica III. - R., 1998, 27.-36. Ipp. 
dē|, līdz ar to parasti formāli (bet tikai formāli) atšḳiras arī to nozīmes skaidrojumi. Piemēram: $\diamond$ iekrist kā akā - pēkšṇi, bez pēdām pazust; un $\diamond k a \bar{a}$ akā iekritis - saka, ja kas pēkšñi pazūd un nav vairs atrodams. Tomēr derētu apsvērrt arī iespēju šādu formālu škīirumu pārvarēt un vārdnīcā šiem loti līdzigas semantikas frazeologisma SiV dot kopīgu skaidrojumu, proti, vispārināt variantu ar verba nenoteiksmes lietojumu, tâtad: $\diamond$ iekrist $k \bar{a} a k \bar{a}$ (arī $k \bar{a} a k \bar{a}$ iekritis u.tml.): [pēkšñi, bez pēdām pazust (arī pazudis)] (protams, seko pāris piemēru ar abu variantu lietojumu un vairāk vai mazāk piln̄̄gs, varbūt arī vispārinăts reg̀istrācijas vietu uzskaitijums). Šādas atveides koncepcijas dzīvotspēju uzskatāmi demonstrē "Zviedrijas izlokšṇu vārdnīcas" paraugs. Tajā norādes par vārdformu, tostarp arī frazeoloǵismu variantu, izplatību nereti dotas diezgan vispārinātā veidā kā, piemēram, allm[änt] (parasti), i vissa uttr[yckor] som (noteiktos izteicienos $k \bar{a} \ldots$...) motsv [arande] frän $S[0 ̈] d[\mathrm{er}] m$ [anland], $M[\ddot{r} r] k[\mathrm{e}], U \mathrm{pp}] l[$ and] (atbilsmes no Sēdermanlandes, Nerkes, Uplandes), tătad no noteiktiem Zviedrijas regioniem.

4. leksiski semantiskie varianti (LSV). Arī tie, tāpat kā jau minētie MV, mēdz būt visai daudzveidīgi. Neapšaubāmi, nozīmju atškirīibas dē atsevišḳi skaidrot nāksies jo daudzus tādus frazeolog̣ismus ar verba braukt lietojumu, kas apzīmē kādas konkrētas darbības nolūku vai adresātu kā, piemēram, $\square$ braukt kacībäs; $\square$ braukt mežă; $\square$ braukt nabaguos; $\square$ braukt reizās; $\square$ braukt svātuos. Tomēr no semantiskās relevances viedokla nav bũtisku atšķirību starp šādiem latviešu izlokšņu frazeologiismu variantiem: $\square$ braukt klaušās (fiksēts Rankā), $\square$ b. gabaluos / kārtuos (Svētciemā), $\square$ b. pastuos (Nīcā), $\square$ b. škūtēès (Popē), $\square b$. šşūtīs (Džūkstē) - "Latviešu izlokšṇu vārdnīcā" tie iederētos

${ }^{2}$ Ordbok över Sveriges dialekter. Red. Reinhammar V. m.fl. $1-$. Uppsala, 1991-. 
vienā frazeolog̀ismu variantu ligzdā (cerā) šçirklī braukt, resp., arī šiem formāli atšşirīgajiem frazeologisma LSV būtu viens kopīgs nozīmes skaidrojums, proti - [pildīt klaušas jeb noteikta veida piespiedu darbus, kas saistīti ar kā pārvadāšanu, izmantojot savu vilcējspēku un transportlīdzekli].

Frazeologismu LSV daudzveid̄̄bas ilustrācijai vēl varam minēt sub v. ak atspogulojamo frazeologiska rakstura vārdu savienojumu repertuāru, proti:

$\square$ ak tu brīnums ar ārā

$\square$ ak debess

$\square$ ak tu debestin

$\square$ ak dievs

$\square$ ak tu gaisā

$\square$ ak jè

$\square$ ak jēmalinass

$\square$ ak Jēziṇ

$\square$ ak kungs (ap žệluojies)

$\square$ ak tu kungs un pestītājs

$\square$ ak tu mī, ak tu žè

$\square$ ak tu mī un žēe

$\square$ ak tavu mulkị (tava mulksa)

$\square$ ak (tu) mūžs

$\square$ ak tavas nedienas

$\square$ ak tava negala

$\square$ ak tu nuolāpìts (nuo lāpīts)

$\square$ ak tu pačibējis

$\square$ ak (tu) pasaulīt

$\square$ ak tu pikis

$\square$ ak tu mī|ā stundin

$\square$ ak tệvs

$\square$ ak tu (debess) tētīt

$\square$ ak tu traks

$\square$ ak tu (tev) tūškis tejuo

$\square$ ak tu vẹlls (pa rāvis)

$\square$ ak tu viens 


\section{$\square$ ak tu vilks ar ārā \\ $\square$ ak tu žè;}

tātad kopā 37 LSV, kā arī jau minētās 5 MV ligzdas ar leksēmu dienin.

5. stilistiski ekspresīvie varianti (StEV). Tā kā ne vienmēr iespējams konstatēt fiksētā frazeologismu materiāla objektīvo ekspresijas pakāpi un reizēm vienīgais rādītājs ir teicēja izmantotā subjektīvā mēraukla, turklāt daudz ko nosaka ekstralingvistiski faktori, nākas veidot savu stilistisko shēmu, kurā būtu paredzētas arī variācijas iespējas. Šajā valodas lìmenī frazeologismu varianti veido vismaz trīs galvenās grupas: I. relatīivi neitrāli varianti (piem., $\square$ brauc bẹkās!; 口 brauc pupās!; 口 brauc purā!); II. jau ekspresīvāki ( $\square$ brauc uz elli (vẹlnam par zelli)!, $\square$ brauc iz elni!); III. visai rupji izteicieni ( $\square$ brauc dirst!). Arī šādi sagrupētiem frazeologismu variantiem nozīmes skaidrojums būtu gandrīz identisks, variētos vienīgi stilistiskā norāde hum[oristiski], iron[iski], niev[īgi], lit[erārisms] vai vienk[äršrruna].

Apkopojot līdzšinējo pieredzi "Latviešu izlokšņu vārdnīcas" manuskripta izveidē un darba procesā aktualizējušos problemātiku, škiet, ka optimālākie frazeologismu variantu leksikogrāfiskās atveides risinājumi varētu büt šădi:

$\alpha$. tradicionālais, atsevišķi neatspogulojot fonētiskos un morfologiskos variantus, ja to eksistence izskaidrojama ar regulārām skaṇu un formu atbilsmēm, bet izdalot sintaktiskos, leksiski semantiskos un stilistiski ekspresivos variantus; nepieciešamības gadījumā uz atšķirỉbām vispārinātā formā iespējams norādīt Skkirk|a sākumdạāa (vēl vispārinātākā veidā vārdnīcas ievadā). Şī tradīcija, kas iedibināta latviešu dialektālās leksikogrāfijas pieminek]u trilogijas aizsācējā Mīlenbaha/ Endzelīna "Latviešu valodas vārdnīcā", principā neizraisa iebildumus, tomēr attiecībā uz turpmākiem leksikogrăfiskiem avotiem jaunā gadu tūkstoša priekšvakarā šḳiet nedaudz iesîkstējusi. 
ß. t.s. "novatoriskais", par pamatkritēriju ṇemot vienīgi semantisko relevanci un attiecīgā frazeologisma ekspresiju: līdzīgi kā "Zviedrijas izlokšnu vārdnīcā" šksirklî ietverot frazeoloǵisma izplatītāko leksiski semantisko variantu, tā nozīmes skaidrojumu un pievienojot norādi, piemēram: Varianter från $S m$ [åland], $\AA$ [nger] $m$ [anland], $L[\mathrm{a}] p$ [pland], $N$ o]r[rbotten] varianti no minētajiem reǵioniem, vai arī vienkārši $D a l[$ arna] [och från] $H[a ̈ l] s[$ ing]l[and] - (till) V[äster] $b$ [otten] Dalarnā un no Helsinglandes lìdz Vesterbotenei. Latviešu izlokšṇu vārdnīcā tas varētu izskatīties apmēram šădi: [kāds frazeologisisms], [tā skaidrojums]: [piemērs]; [norāde]: varianti no Dignājas, Dunikas, Jeriem, Kalupes, Meirāniem, Mežotnes, Nautrēniem, Pildas, Rucavas, Saikavas, Sinoles, Vainižiem, Valmieras, Ziemera; vispārinātākā veidā Zieme|vidzemēe, Malienā, Dienvidvidzemēe, Viduslatgalē, Zemgalē, Dienvidaustrumkurzemē u.tml.

Varētu apsvērt arī šādas formalizētas norāžu sistēmas noderīgumu topošajā LIV, tomēr jau apriori šķiet, ka latviešu dialektālajā leksikogrāfijā tā diez vai būtu pieñemama vismaz divu iemeslu dēl. Tie ir 1) uz pilnīgi pretējo, analītisko principu un vietas piesaistes lingvistisko, nevis geogrāfisko klasifikāciju vērstā latviešu valodniecības tradīcija, $k \bar{a}$ arī 2) materiālu vākumu neviendabīgums, kas nejauj pilnīgi droši spriest par valodas parādību lingvogeogrāfisko stratifikāciju, resp., modelēt to lietojuma izplatību visās izlokšñu grupās.

Hipotētisks secinājums: novatoriska risinājuma gadījumā uz formvariantu daudzveidības rēķina iegūtu vārdnīcas leksikogrāfiskā precizitāte un zinātniskums, gan jūtami apgrūtinot šķirk|a uztveri kopumā; savukārt turpināt tradīciju tikai tradīcijas dē| nebūtu pārāk lietderīgi. N̦emot vērā ne vien vārdnīcas veidotāju, bet galvenokārt arī "patērētāja" viedokli, acīmredzot ieteicamāks būtu kāds kompromisa variants starp tradīciju un inovāciju. 
PROPONETÃ DIALEKTALAS FRAZEOLOĢIJAS VARIANTU ATVEIDES SHEMA

\begin{tabular}{|c|c|c|}
\hline $\begin{array}{l}\text { Variantu } \\
\text { veidi }\end{array}$ & $\begin{array}{l}\text { Skkirkli ietvertic } \\
\text { frazeologismi }\end{array}$ & Skkirkla apdare \\
\hline & 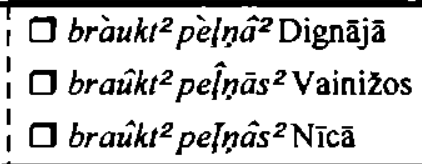 & $\begin{array}{l}\square \text { braukt pelna } \bar{a}(s) \text { - } \\
\text { [skaidrojums]. }\end{array}$ \\
\hline II. MV: & $\begin{array}{l}\square \text { ak tu diêniñ } \hat{n}^{2} \text { (Vainižos); } \\
\square \text { ak tu mana diêniñ }{ }^{2} \\
\text { (Vainižos); } \\
\square \text { ak tu ma(:)n diênin }{ }^{2} \\
\text { (Popē); }\end{array}$ & $\square$ ak tu (mana) dienin, \\
\hline & $\begin{array}{l}\square \text { ak manu dienin (Pālē); } \\
\square \text { ak tu manu diêninu }{ }^{2} \\
\text { (Kursišsos); }\end{array}$ & $\begin{array}{l}\square \text { ak }(t u) \text { manu } \\
\operatorname{diening(u),}\end{array}$ \\
\hline & $\begin{array}{l}\square \text { ak tu mìla diênina }{ }^{2} \text { ! } \\
\text { (Kursīšos); } \\
\square \text { ak tu mìlu diêninu }{ }^{2} \text { ! } \\
\text { (Kursīšos); }\end{array}$ & $\begin{array}{l}\square \text { ak } ı \text { u mìla dienina } \\
\text { (arī mïlu dieniņu), }\end{array}$ \\
\hline & $\begin{array}{l}\text { 口 ak mûž } a^{2} \text { diêninga }{ }^{2} ! \\
\text { (Nīcă); }\end{array}$ & ak mūża dienina, \\
\hline & $\begin{array}{l}\square \text { ak tu dien }{ }^{2} \text { ! (Bebrenē); } \\
\square \text { ak tu dieninãs }{ }^{2} ! \\
\text { (Bruknā). }\end{array}$ & $\begin{array}{l}0 \text { ak } \text { tu dienin̄ās } \\
\text { (arī dieñ) - } \\
\text { [skaidrojums]. }\end{array}$ \\
\hline III. SiV: & $\begin{array}{l}\text { 今 iekrist } k \bar{a} a k \bar{a}- \\
\text { [skaidrojums]; }\end{array}$ & $\begin{array}{l}\text { 仓 iekrist kāa akā } \\
\text { (arī kā akā iekritis } \\
\text { u.tml.) [vienots } \\
\text { skaidrojums]: }\end{array}$ \\
\hline
\end{tabular}




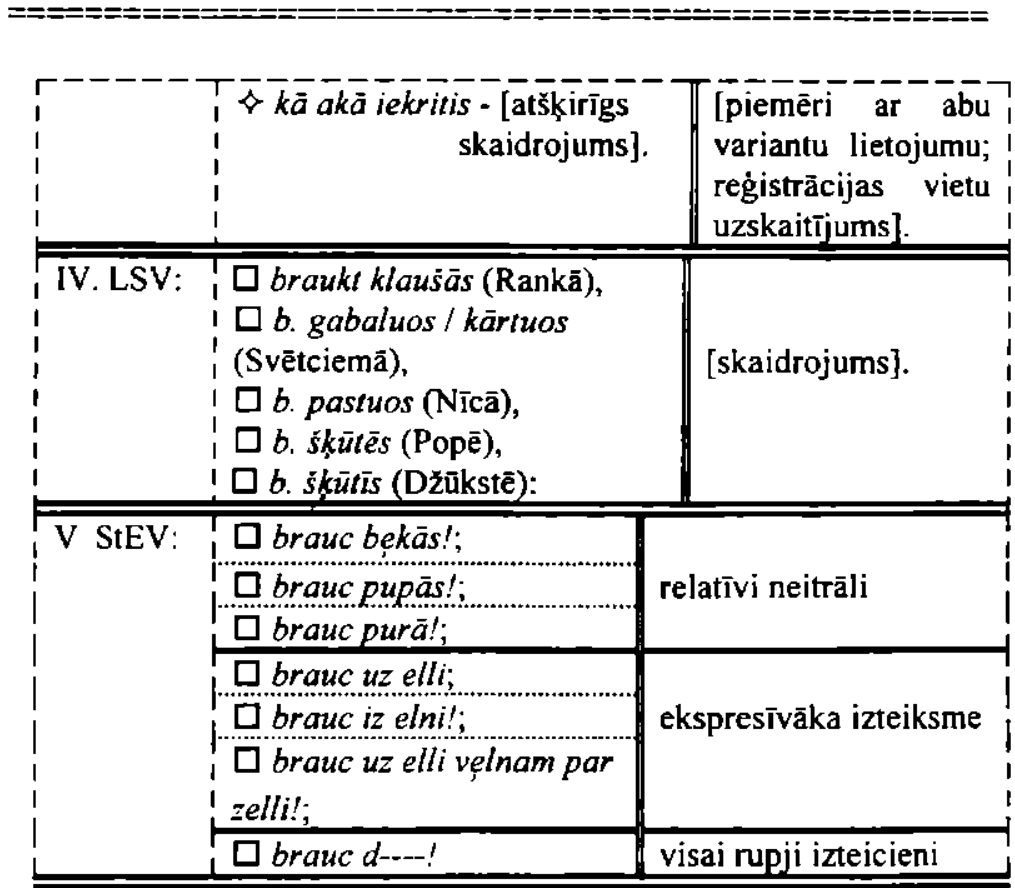

\section{Lexikographische Überlegungen zur Variabilität mundartlicher Phraseologie Zusammenfassung}

Im Beitrag wird die Vielfältigkeit der Varianten mundartlicher Phraseologismen im Lettischen erörtert sowie ein allgemeines Schema für ihre Wiedergabe in dem zu erstellenden "Mundartwörterbuch des Lettischen" proponiert. Es werden die wichtigsten Arten von Varianten kurz charakterisiert: 1) phonetische Varianten; 2) morphologische Varianten; 3) syntaktische Varianten; 4) lexikalisch-semantische Varianten; 5) stilistisch-expressive Varianten.

Von der semantischen Relevanz und dem Expressivitätsgrad des im neuen Wörterbuch zu reflektierenden Sprachmaterials 
(darunter auch der Phraseologismen) ausgehend, gelangt der Verfasser zur Schlussfoigerung, dass die traditionelle Praxis der lexikographischen Wiedergabe mundartlicher Lexik, obgleich sie mit den wesentlichsten theoretischen Prinzipien übereinstimmt, so doch um die Jahrtausendwende etwas veraltet erscheint. Daher wird den Erstellern von Mundartwörterbüchern der sogen. "novatorische" Lösungsweg dieses Problems nahe gelegt, und zwar - mittels eines neuartigen, unifizierten Systems von geographischen Ortsangaben und adäquater synthetischer Beschreibung sprachlicher Fakta auch die Aufbaustruktur des Wörterbuchartikels optimal zu gestalten.

Außerdem dürfte im Fall einer novatorischen Lösung auf Kosten der Vielfältigkeit von Formvarianten die lexikographische Genauigkeit des betreffenden Wörterbuchs gesteigert werden, wenn auch die visuelle Auffassung der Artikel dadurch erschwert würde. Es wäre wohl angebracht, nach einem vernünftigen Kompromiss zwischen der Tradition und Innovation auf diesem Gebiet zu suchen. 


\section{Brigita BUŠMANE \\ IZLOKŠNU TEKSTU FRAGMENTI "LATVIESU VALODAS DIALEKTU ATLANTA $\bar{"}$}

"Latviešu valodas dialektu atlanta" leksikas dala" ir pirmais plašākais darbs latviešu valodas dialektu izpētē lingvoǵeogrāfiskā aspektā. Tajā ieklautas 100 kartes ar komentāriem, kuru tematika ir daudzveidīga: ir apkopoti ar floru, faunu, kā arī ar tautas materiālo un garīgo kultūru saistīti nosaukumi. LVDA galvenais mērķis ir sistematizēt izloksnēs sastopamos dažādu reāliju, parādību un jēdzienu nosaukumus un atspogulot to izplatibu.

Atšķiribā no pēdējos gadu desmitos kaimiṇvalstīs izdotajiem, piemēram, lietuviešu un baltkrievu valodas leksikas atlantiem $^{3}$, LVDA ir vairāk ietverts ilustratīvais materiāls: izlokšnu tekstu fragmenti teikumi vai teikumu da|as. Ilustratīvais materiāls komentāros (iekavās aiz attiecīgās izloksnes numura) ir dots ar zināmu atlasi. Tā izvēli ir nosacījuši kā valodiski, tā nevalodiski faktori, kas dažkārt ir cieši saistīti.

I. Valodiskā aspektā izlokšņu tekstu fragmenti ir nozīmīgi vārda semantikas atklāšanā, izlokšñu raksturīgo parādību ilustrācijā, vārdu krājuma dinamikas atainošanā.

I Raksta pamatā ir Saulu universitātes Humanitārās fakultātes dialektologijjas centra organizētajā zinātniskajā seminārā 1998. gada 24. aprīlī nolasītais referāts; sk.: Bušmane $B$. Izlokşnu tekstu fragmenti Latviešu valodas dialektu atlantā // Tarmès: tyrimas ir perspektyva: Mokslinis seminaras, skirtas kalbininkès dialektologès Aldonos Jonaitytès 70-mečiui. Pranešimu tezès: Šiauliai, $1998 \mathrm{~m}$. balandžio 24 d. - Šiauliai, 1998. - 6.- 7. Ipp.

${ }^{2}$ Tāa sagatavota Latvijas ZA Valodas un literatūras institūtā; kopš 1989. gada atrodas izdevniecībā "Zinātne" (turpmāk - LVDA).

${ }^{3}$ Lietuviц kalbos atlasas, I. Leksika. - Vilnius, 1977.; Лексічны атлас беларускіх народных гаворак у пяці тамах. - Т. 1. - Мінск, 1993; Т. 2. - Мінск, 1994. 
1.Viens no svarīgākajiem izlokšṇu tekstu fragmentu uzdevumiem ir atklāt vārda semantiku, jo LVDA ir iek|autas vairākas tematiskas grupas, kurās izloksnēs konstatētas semantiskas atškiribas.

Semantiska dažādība vērojama dažās ar floru vai faunu saistītajās leksikas grupās. Piemēram, nosaukums ķirsis, kas ir arī literārās valodas vārds (LLVV IV 548; aizgūts no Iv. kirs, sk. ME II 385, LEV I 475), ir izplatīts Kurzemē, Zemgalē un Vidzemē, retāk to sastop Augšzemē un Rietumlatgalē (sk. LVDA 3. kartē). Bet vairākãs izloksnēs Kurzemē, Zemgalē un Auǧžmē līdzās tam sastop otru aizguvumu - kezbere vai tā variantus kezbēre, kezberis, kezbiere, kezbieris (aizgūts no vlv. kersebere (kasbere) ME II 372 vai lv. kessebēre, käßbēr Sehwers 64). Da|ā izlokšṇu vārdu ķezbere vai tā variantu uzlūko par senāko koka apzīmējumu, piemēram, Džūkstē: ķirssî pa vẹcâm saûca kezbêre, taganâs saka - kirîsis; Jēkabniekos: kezbẽre - tas $i$ vẹcu laūku vârc. Bet vietām teicēji ir norādījuši, ka vārdu kezbere vai tā variantu lieto ar nozīmes niansi, proti, tas apzīmē kādu noteiktu ķiršu šķimi, piemēram, Remtē: kezbẽre - tã tâda

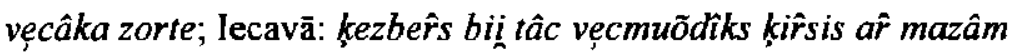
uôzinâm; Zantē: kezberi - vệliê ķirši, liêlâki kuôki, arî uôgas liēlâkas, skâbâki. Piebilstams, ka Latviešu literārās valodas vārdnīcā (LLVV IV 54l) vārds ķezbere dots ar nozīmi 'saldais ķirsis' un tiek atzīts par apvidvārdu; ilustrācijai ir minēts tikai viens piemērs no literatūras.

Cits piemērs. Uz kokiem parazitējošas sēnes resp. piepes apzīmēšanai gandrīz visā Latvijā lieto arī literārajā valodā pazīstamo vārdu piepe (LLVV IV ${ }_{2}$ 98; sk. LVDA 13). Bet

\footnotetext{
${ }^{4}$ Lai atvieglinātu teksta uztveri, rakstā norāde uz intonāciju sakritumu vārdă (t.i., divnieks aiz attiecīgā vārda pie mazā burta augšējās līnijas) nav dota. Par intonāciju sakritumu izloksnēs sk.: Rudzîte $M$. Latviešu valodas vēsturiskā fonētika. - R., 1993. - 109.- 110.lpp.
} 
galvenokārt Kurzemē atšksirīgs nosaukums ir registrēts bērza piepei - te sastop no krievu valodas aizgūto vārdu ćaga $(<\mathrm{kr}$. dial. чаеа ЭСРЯ IV 310). Ilustratīvais materiāls ietver gan čagas aprakstu, gan norāda uz tās atšķiribu no piepes, piemēram, čaga

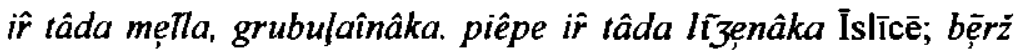
piêp tâc gludans, bet čâg $i$ tâc čumar̂s, tâc sačumar̂jess, tâc kroblaûns Popē. İpašs nosaukums, kā liecina izlokšnnu dotumi, senāk ir bijis arī piepei (parasti uz bērziem parazitējošai), ko raudzējuši un žāvējuši uguns uzšḳilšanai, piemēram, daglis Remtē: daglis izaûg nuô bệrza, ievaînuõjumâ aûg, saciêtê. arî nuô piêpes mîkstumiêm iskaltểja škittivâm de zinãmuô dagli;

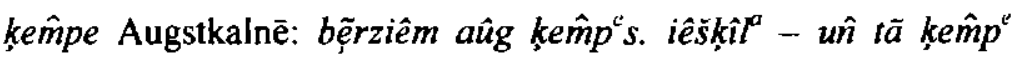
aîzdegâs; pùoss Mārcienā: agrẹ́k piépas råúzẹèsi priekš pùosa.

Zieme|rietumvidzemē, kur sastop arī literāāās valodas vārdu varde, to lieto ar nozīmi 'za|ā varde (Rana esculenta)', bet plavu vardes resp. pelēkās vai brūnās vardes apzīmēšanai parasti ir aizguvumi konna vai kunna (< ig. konn ME II 316, sk. LVDA 29), piemēram, Ainažos: koñn i pelékie un brünie, kas uz zem కivuô, bet tiē zalie $i$ vấds; Omulos: mẽs sàucàm tùo zaluô pa vấd, ka pa sàuszem ${ }^{i}-k_{u n n}{ }^{a}$

28. kartes (žurka) komentārā ietvertie izlokšṇu tekstu fragmenti atklāj vārda kalmuks nozīmi Kurzemes dienvidrietumos parasti tā sauc lielu, vāju žurku, piemēram, Grobiṇā: tiẽ liẽliẽ šuôrki - tiẽ jaû ir kalmuki; Nīcā: tâc vâs̆, ispũris, kũc, ta tiẽ i kalmuki.

Nozīmes skaidrojumi ir nepieciešami vai vēlami vārdiem, kas saistās ar materiālo kultūru. Tāpēc samērā daudz ilustratīvā teksta ir iek]auts komentãros, kas veltīti dažādiem siena krāvumiem, kam Latvijas novados vērojamas nianses.

\footnotetext{
${ }^{5}$ Par to sk. arī Kagaine E. Lokālo aizguvumu semantikas sałaurināšanās un diferencēšanās (Baltijas somu valodu aizguvumi) // LZA Vēstis. A. dala. - 1997. - Nr. 3/4. - 24.-25. lpp.
} 
Atlantā ir izdalīti divi galvenie siena krāvumu veidi: apali krauta siena gubiṇa un neliels, garens siena krāvums - stirpiṇa (LVDA 68, 69). Teicēju skaidrojumos rodamas norādes par dažviet sastopamo nozimju diferenciāciju, tie dod priekšstatu par niansēm gubiṇu kraušanā (par lapkoku zaru, paresnu koku ar apcirstiem īsiem zariem - žeperu - izmantojumu) u.tml.

2. Izlokšnu teksti palaikam atklāj nosaukuma semantisko jeb leksisko motivāciju. Tie liecina par tautas bagāto iztēli, tradīcijām un var sniegt materiālu ne tikai ar nomināciju saistīto jautājumu, bet arī citu valodisku problēmu risināšanai, piemēram, vārda cilmes skaidrojumiem, sistēmisko sakaru un attiecību izpētei dialektālajā leksikā un vārddarināšanā, leksiski semantiskās v'ariēšanās cēloṇu noskaidrošanai.

Piemēram, bērzu piepes nosaukumi dagle, daglis, dagls ir atvedināti no verba degt, jo piepe tika īpaši sagatavota izkaltēta - uguns uzškilšanai un labi dega. To apliecina Rendā pierakstītais teksts: tikâ̂ bẹrziêm aûg dagles. kad nebij špicku, tad veciē šķūla uguni ar škittavu. saûsa dagle labi aîzdegâs (LVDA 13).

Norādes uz lietvārda - putna, auga, priekšmeta, èdiena nosaukuma - saistību ar verbu atrodamas arĩ citos komentāros; piemēram, kovārna nosaukums čàguons ir saistīts ar verbu čàgăt: čàgùonu dàuc', t'i čàgòi v'înâ čàgoîšonâ Bẽrzgalē (LVDA 37), rèibenes 'zilenes' - ar rèibt: nu rèib'enu gotva rèipst $i$ nalops griš Šķilbēnos (LVDA 25), deñcītis 'vērpjamā ratina klaniṇa' - ar dañcuot: deñcĩc dañcuõ, ka ratĩnu min Smiltenē (LVDA 80), cükstalas 'dradži' - ar čitkstêt: cư ikstalas êdām àr

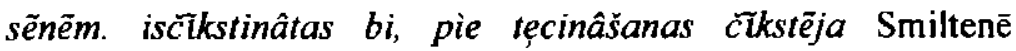
(LVDA 73), kriükši 'dradži' - ar kriükšèt: kriükšs' jaû kriükš, vin tâd ciêt ir Ozolos (LVDA 73).

Dažkārt teicēji, skaidrojot nosaukumu, ir minējuši kādu būtisku priekšmeta, dzīvnieka pazīmi, kas ir nosaukuma motivācijas pamatā. Šādas piezīmes rodamas, piemēram, pie 
spī|arkla nosaukuma divkājîtis: diunkäjîc, kuô kârtupelus ar. citi pâr diunkäjiti saûc, tâdas plezninas divas bija Jaunsvirlaukā un ragàinîtis: tis vârc jàu pa's', tác rågoîníc' vién i'r àr rogiêm Kusā (LVDA 64), pie vērpjamā ratiṇa klaniñas nosaukuma spèciñns: pàr spèciņu sàuca, vinàm tas spệks Lēdmanē (LVDA 80), pie stārḳa nosaukuma svẹtulis: stòrk ${ }^{a} s$ - vi:ņ ${ }^{\mu} s$ sòu ${ }^{\top} c$ pàr svàtüliém àr, tămdẹl kå svò c pu:tns Mētrienā (LVDA 36).

Semantiski daudzveidīgi ir pelaṣ̌u nosaukumi, vairākus no tiem teicēji ir skaidrojuši: asins zâle. àr asins zuôles lopâm vàr àisturêt asinis Kalncempjos; ežu puk:e aûg uz ežas Zvārdē, ežu zâle aûga pa ežăm, tur vinas nèizara Bērzē; mêra puḳes. bịns liêls mêr's, cil̂ệk atraduš, zệruš, mêr's beîziês Basos; tütardilling'

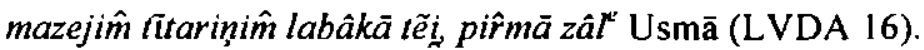

3. Izlokšņu tekstu fragmentos nereti ir dotas teicēju norādes par vārda lietojuma ierobežojumu resp. tā lietojumu dažādu paaudžu pārstāvju valodā vai arī dažādos laika posmos. Tās lauj spriest par vārdu krājuma dinamiku. Šis ziṇas ir nepieciešamas, jo atlanta kartotēkā bez tās pamatmateriāla, tas ir, vākumiem, kas pierakstīti ekspedīcijās kopš 1953. gada, ir ietverti arī senāki materiāli, piemēram, Filologu biedrības rakstos publicēto izlokšṇu aprakstu dotumi, K.Mīlenbaha "Latviešu valodas vārdnīcā" un tās papildinājumos reg̀istrētā leksika, da|ēji K.Barona "Latvju dainās" sastopamais vārdu krājums. Tādējādi leksikas dạas kartēs ir ieklauts materiāls, kas savākts ap 100 gadu garā laikposmā.

Atlantā materiālu vācēju piebildes par nosaukumu lietojumu dažādu paaudžu valodā, dažādos laikos komentāru tekstā bieži ir dotas saīsināti, piemēram, "jaun. p." (lieto jaunākā paaudze), "vid. p." (lieto vidējā paaudze), "vec. p." (lieto vecākā paaudze), "visvec. p." (lieto visvecākā paaudze). Norādes "senāk", "tagad", "novec." (novecojis), "liter." (literārisms), "jaun. nos." (jaunāks nosaukums), "jaun. f." (jaunāka forma), 
"vec. nos." (vecāks nosaukums), "vec. f." (vecāka forma), "parasti", "biežāk", "reti" devuši vai nu paši vācēji, vai arī tās izsecinātas no konteksta - teicēju stāstījuma, paskaidrojumiem. Bet dažkārt komentārā teicēju skaidrojumi, kas liecina par vārdu krājuma attīstību, par lietojuma biežumu u.tml., ir citēti, tā saglabājot visu doto informāciju.

Piemēram, nereti tekstu fragmentos ir norādes, kurš nosaukums izloksnē ir senāks, kurš jaunāks: senâk sili viên bij, tâdi vir̂ši nebij zir̂têti Zantē (LVDA 21); agrak cücens viê bi mežos, mellens ne-maz nesảûc Jeros (LVDA 24); ātrak tig runẹ pa koüpinim, pa kobinìm, kâ kûr rẽ̃z Upesgrīvā (LVDA 30); tagad sak - mušs, bet agrak sacii - müs ${ }^{a}$ tã tok $i$ vẹc ${ }^{\mu}$ laik valod - mūs ${ }^{a}$ Naukšēnos (LVDA $31 \mathrm{~A}$ ); puķêm sal̂lda smaka, bet jaûnsmuõdîgi saka - smârža Skrundā; māla plãns rijâ, ķêkêe, visû̂. pêc šuõ laũku - kluõns Ezerē (LVDA 59). Bieži ir minēts, ka nosaukumu vai tā variantu lietojusi vecākā paaudze resp. māte, vecāmāte u.c., piemēram, šuôrks - tâ teîc man mãt, es sak š̂rk Rendā (LVDA 28); vẹcãmãte kâdreĩz vẫdi saûca pa ķaûpi, teîca: "re, kû̂ ķaûpis lẹc!" Augšiecavā (LVDA 29); vẹc'e lốž sâls sốc pa kallàm un kuôk pud'ẹr plâvs vid'e, a pa kall Puzē (LVDA 31 B); kañgs - dâz veccum vẹc cilêciñ saûc ${ }^{a}$ [stelles] Kurmālē (LVDA 81). Ir sastopamas piezīmes par nosaukuma lietojuma biežumu, piemēram, pàr osùkl'àm toža sàuc [ērkšķogas), vàiroîk vus - ogruškys Nautrēnos (LVDA 26); tupulus ['kartupelus'] sàuce gòn pàr zemes "âbuliem, bet reši Sinolē (LVDA 44), par lietojumu ar pejoratīvu noz̄̄mi,

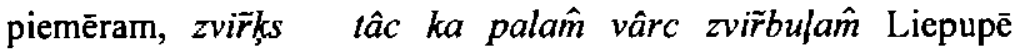

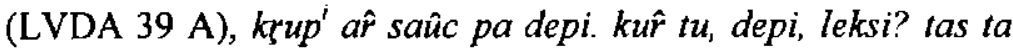
kâ lamu vârc bûtu Virgã (LVDA 30), kā arī par vārda semantikas paplašināšanos, piemēram, ka lamâtiês grib, ta jâ̂

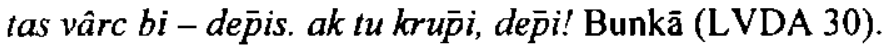


Interesants ir Gaigalavā pierakstītais teksts, kurā skaidrota kartupe]a nosaukumu daudzveidỉbas cēlonis izloksnē: kaî m'èilàm bầrnàm dàu żi vùordu, tâi i bùlvài (LVDA 44).

4. LVDA komentāros pa lielākajai da|ại ir ietverti tekstu fragmenti, kas atspogulo izlokšnuu iezimes dažādos valodas līmeños, piemēram, fonētikă vokālisma kvalitātes un kvantitātes maiņas, patskaņu un līdzskaṇu zudumu un iespraudumu, morfolog̀ijā īpatnības vārdu darināšanā, deklinācijā un konjugācijā, refleksīvformu veidošanā, sintaksēe locỉjumu formu lietošanā. Ilustrācijai fragmenti no dažādās izlokšņu grupās pierakstīta teksta: påuseruôs viê nệdi åpluôki jåsălåbuõ, citệdi luõpi àiziês kùr kuråîs Vecpiebalgā (LVDA 52); iê-iêm" dâr'zâ - vĩbat's pār' gâlvầ Lìvbērzēe (LVDA 19); te nuô pilsâta adgāja, sarâva vĩzîrnes Dunikā (LVDA 20); joûna mẽnesa stāditi kar̂tini izoûg lakstas Svētciemā (LVDA 44); våî̀åráii - tie priè š kuódệm Cesvainē (LVDA 18); pajaglu p'i myûsu moz jira Nīcgalē (LVDA 9); saza-iês's'i dàuz' r'èib'inu $i$ apr'èips'i Ozolainē (LVDA 25); pokùls' to gàdnys ka dazatàisa, ta c'ikàm vysas vystas abgrîš Škilbēnos (LVDA 27); lops kàim'in'c' tàišni lobuôks kầ tuôl'ejs rad'in'iks Gaigalavā (LVDA 92).

Ilustratīvais materiāls ataino arī leksisko daudzveidību. Piemēram, 38. A kartes (pūce) komentārā minēti dažāồi verbi, kas raksturo pūces radītās balss skaṇas, piemēram, pūce blấ $k \bar{u}$ vist? Tumē, brệc Augšiecavāa, Bilskā, Braslavā, kliedz Bilskā, m'iekš k'ề jầrs Nautrēnos, vàid Tirzā, vệkškì Kalsnavā. Savukārt 43. kartes (kaṇepe) komentārā atrodami vairāki kaņepju produktu un ēdienu nosaukumi: alejs Vārkavā, kanepju sviêsts Bērzēe, kanup(j)u biezaputra un kaņup(j)u piens Lìvānos, kami Ozolos, piki Mārcienā, tem̃ois Kārḳos.

Ilustratīvie fragmenti dažkārt atspogu|o vārda lietojumu salīdzinājumā. Salīdzinājumi var sniegt liecības par noteiktām 
likumsakarībām valodas veidošanās procesā, jo tieši salīdzinăjumi kā metaforu rašanās pamatmehānismi tiek uzskatīti par vienu no svarīgākajiem pasaules izzināšanas un valodas veidošanas līdzek|iem. ${ }^{6} \mathrm{Kā}$ liecina izlokšṇu materiāli, izloksnēs registrētajos salīdzinājumos bieži ietilpst dialektālā leksika, piemēram, vèikla ká ķirzata Mēdzūlā (LVDA 34), sỳldoás koá šk'ierzlànc sàul'eit'é Aknīstē (LVDA 34), siêna maîs pills tâ kâ depis Medzē (LVDA 30), krèit kuô mòusas iz mada Jaunlaicenē (LVDA $31 \mathrm{~A}$ ), p'izapjutus'ä s'ââ' kầ pỳuc'ä Sakstagalā (LVDA 38 A), skoûdiks ka piêps Limbažos (LVDA 13), sâd kuô vaca pes̄e Ziemerī (LVDA 13), stàigòi, sal'èic'c' k'ế kùplys Bērzgalēe (LVDA $63 \mathrm{~B}$ ), spross [-ts] k'ế vosorys komoc Nautrēnos (LVDA 63B), gùl' k'ến šnops Nautrēnos (LVDA 40), iêt kâ pażaga-tas $i$ tâc palamvârc, ka tâdas dikti žiglas sieviêtes, skrêjêjas lielas Vecumniekos (LVDA $75 \mathrm{~A}$ ), nedelas iêt kâ vẽvera atspuõles Džūkstē (LVDA 82), mǚe kâ laĩdara vârti Skaṇkalnē (LVDA 52), slinjks tâ kâ gurķ̧s Basos (LVDA 93 A).

II. Ilustratīvo piemēru izvēlē ir ṇemti vērā arī vairāki nevalodiski nosacījumi.

1. Saturiskais aspekts, piesātināta kultūrvēsturiska informācija ir îpaši aktuāli, piemēram, etnogrāfijā. LVDA komentāros ir iesaistīti tekstu fragmenti, kas ietver ziṇas par tautas materiālo un garīgo kultūru. Ir doti nelieli dažādu reāliju, to uzbūves, ieguves apraksti. Ṣ̌̂ informācija ir būtiska komentāros, kas veltīti etnogrāfiskām reālijām, kuras mūsdienās nav sastopamas vai to lietojums ir ierobežots.

${ }^{6}$ Par salīdzinājumiem dažādos aspektos sk., piemēram, Timuška $A$. Vārda semantiskās struktūras aktualizācija salīdzinājumos // LZA Vēstis. A da|a. - 1997. - Nr. 3/4. - 20.-23. lpp.; Timuška A. Reg̀ionālas dialektālas komparatīvkonstrukcijas salīdzinoši vēsturiskā aspektā // VIII tarptautinio baltistų kongreso "Baltų kalbos XVI ir XVII amžiuje" pranešimy tezès $1997 \mathrm{~m}$. spalio 7-9 d. - Vilnius, 1997. - P. 137-138. 
Piemēram, 41. kartes (rudzu statịnš) komentārā atrodamas teicēju norādes par kūlīšu skaitu, krāvuma veidu u.tml.: kuōpinas sanẹs gubâs, saliêk trîs vidû un citas liêk rin̄k̂n apkârt, ap sešpacmit $\Gamma_{3} 3$ astuônpacmit kuõpinas gubâ. tad taĩsa nuô viênas kuõpinas cẹpuri. citi likuši kuõpingas galu ar vārpâm, graûdiêm vî̂sû [uz augšu], bet citi liêk salmus vîrsû, tad vārmas nelaîzuôtiês. tad apvij gubu grîstêm, piêsiên cẹpurîti Allažos; kotrâ stajànkâ pa d'ev'in'i snop'i, $i$ dasm'it'is snops Vi|akā.

56. A kartes (apcirknis) komentārā var gūt priekšstatu par apcirkṇu uzbūvi, to izmantošanu labỉbas, arī produktu (piemëram, ga|as, olu) uzglabāšanai: apcir̂̀nni bi aûksti, bi cilvệkâ̂ gấs klât, ka bi jâkaŗâs iêkšâ Džūkstē; ka gal abžâveĭ ta lik ruz apcîkni iêkša, ùn labiba, såûsuma, vin̂́c vẹc negãi Jeros; kviêšu apcir̄knī ir uõlas iêrakâtas Braslavā.

57. kartes (pelūde) 'novietne pelavu glabāšanai' komentāra ilustratīvajā materiālā ietvertas ziñas par pelavu novietṇu veidiem (va|ējām vai da|ēji slēgtām), par nojumes vai piebūves atrašanās vietu u.tml.: gubeñ bi piêtaĩsit pie kücgal vâ̂ klëcgala Vainižos; p'i kula àr s'l'èipu jùmtu datàis'eîta pašela. pašel'iê saźèina palavys Kalupē; pẹlavas mẹt stâğenê - tã tiêk būvêtı tuvu piê luõpu kūc Medzē.

65. A kartes (grābeklis) komentārā var uzzināt par materiālu koku, kas ir parasti izmantots grābekja, tā daju gatavošanai: grâbekla kuôtu tàisija nù eglites, gốlvu nù apses, apse vigla ùn isturîga, zorus nù ûzula Stāmerienā; grâbeklî̀ gâlvinu taĩsa nuô uôzuôla, uôśa, kâtu - nuô egles kuôka Bārtā; grâbeklê iêliêk jaûn"s zar"s nuô iskaltušiêm plẽderin zariêm Valgalē.

Nelieli tekstu fragmenti biezpiena nosaukumiem veltītajā komentārā (LVDA 71) ietver ìsu produkta iegūšanas pañēmienu aprakstu, jo nereti nosaukumi biezpiens, kupināts 
piens, sildīts piens u.c. apzīmē dažādos veidos (tas ir, sildot, mazāk sildot vai pat īpaši nesildot) iegũtu produktu, kā arī norāda uz šo nosaukumu atšksirīgo lietojumu. Piemēram, sarûgûšuô piēnu iêliêk gräpitî, sasitda, nuôtẹcina sûkalas, tas

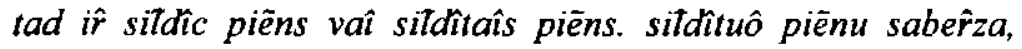
piêmeta sâli, kimenes, piêlika kreîmu klât, samîcîja, sataĩsîja knapsiērus Džūkstē; kadreĩz nesitdija [rūgušpienu]. uzgâza sarûgušu piēnu uz linu drān"s un ta tik itgi turêja, liz tā sûkalina nuôtẹk nuõst. tas bi kupinâtaîs piēns Virgā; kupušpiēns [ir] biêspiẽns, sajaûkc â̂r rûgušpiẽnu, krêjumu Matkulē.

Etnogrāfiska rakstura zinas atrodamas vēl vairākos citos komentāros, piemēram, 53. kartes (govju kūts), 55. A kartes (šksūnis), 59. kartes (klons), 63. A kartes (zirga sakas), 67. kartes (apārnis), 44. kartes (kartupelis) komentārā.

2. Etnogrāfiska rakstura informāciju nereti papildina ilustratīvais materiāls, kas atklāj tautas vērojumus, dzīves pieredzi, ticējumus un paražas. Virkne vērojumu, ticējumu saistās ar dabas parādībām, laika apstākju un ražas prognozēšanu, piemēram, ka âbeles ziêdẽja, ta sâka städît

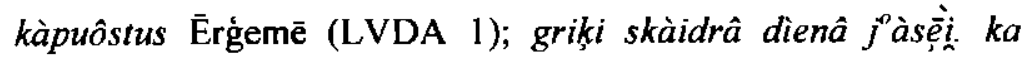
migla, ta griḳi na-izduôdâs Sinolē (LVDA 42); ka pîleñgi i ziêd, ta zivim $i$ nârsc Daugulos (LVDA 5-7); ka eglẹ̀m pùlka ciekùržu, ta tupuli labi izduôdùotiês Sinolē (LVDA 10); ja pir̂meš pếrkoñc iêrûc salapoiššs kuôkas, bûs sî́t vasar Vainižos (LVDA 85); żèiguri živina, boûs litti Litenē (LVDA 39 A); z'ìmâ, ka vùornys sazamat kùka v'iersyûn't, soka byûs soltum'i Nautrēnos (LVDA 12); pỳlnâ m'ien'es'î cỳuka jùokaûn i klubn'iks jùostota Bērzgalē (LVDA 23).

Vairāki ticējumi saistās ar jaunpiena ēšanu, piemēram, jaûnuõ piēnu ar karuôti nểda, tad gùos speruotiês Liepā; joûna

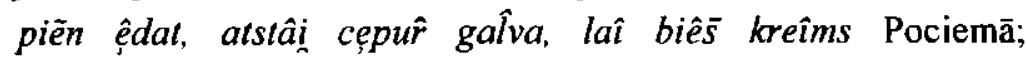


joûnguôupiẽn nedrîkst griêst, tad guôvem pavasara sprẹga pups Duntē (LVDA 70).

Dažos komentāros iekjauti izlokšṇu tekstu fragmenti, kas lauj ieskatīties tautas ārstniecībā, piemēram, źeiv'i s'v'ẹkèjli rànas žid'êj Aknīstē (LVDA 11); vẹcāmāte kadika sluôtinu pirnti applaûceja tas labi patīzuôt pret tâdiêm niēzuliêm Augšiecavā (LVDA 9); pàgl'is' sakn'is' s'p'ìrtâ lab'i nu raka 'vēža' Šķaunē (LVDA 9); dêles i labas. senâk katra viêna saīmniêce turêja dêles butelês, ik pa trîs diênâm tik ûzlika skaĩdru ûdeni Nīgrandē (LVDA 33), mẹthâs [dēles] liêtuô ärstniêcîbâ. tãs vẹlk nepareĩzâs asinis, rudâs nê Bārtā (LVDA 33).

Ilustratīvais materiāls dažkārt atspogu|o ticējumus un paražas, kas saistās ar gadskārtu svētkiem, ar mitologisko būtṇu aizdzīšanu, piemēram, Ziemassvàtku no:ktìe gà ovåna kărt Lubejā (LVDA 51), meîtaî Jaûngada nakti jâḳ̂er âttkuĩls Idũ (LVDA 51); pĩläzis ir viênc bura kùoks. tas ir vellla peramàis kùoks K̦ēčos (LVDA 5-7), pîlă̧̌i tak svệt kuôk' - ar tiẽm vis"s

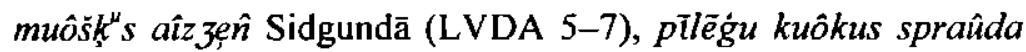
dârzuôs un sta|luôs, lâ̂ nenãk raganas un muôšḳi Zemītē (LVDA 5-7).

Kopumāa da|ā komentāru ietvertie tekstu fragmenti sniedz daudzpusīgu, interesantu informāciju par tautas senāko dzīves veidu, garīgo kultūru. Tã, piemēram, 29. kartes (varde) komentārā izlokšnu materiāāa ir ne tikai norādes uz iepriekšminētajām semantiskajām atšḳirībām šajā leksikas grupā (sk. 72. lpp.), bet arī piezīmes, kas liecina, ka pēc varžu krāsas vai atrašanās vietas ir paregoti laika apstākli, govju pienīgums (ja kuñna i zệttẹ̃na, ta liêtus nàu, ka mẹlla - tas i uz liêt ${ }^{u}$ Kārḳos; soûsa laūka jâsit kuñns, tad liêts lîst Pociemā; ka nùsyt vârgl'i, byûs' l'eîc Višşos; ka kuñn rẹ, 3 [pavasarī pirmo reizi] ûdeni, ta bûšim bût piẽn gac: ka rȩ̣z uz sảûs zem, ta nåu Jeros), ka vardes 
izmantotas ne tikai vēžu ḳeršanā (a kuñnâm vêż $s$ k $k \hat{r}$ - nuôdîrã kuñn's un liêk uz vêžu ḳeramiem krîñniẽm Skaṇkalnẽ; samekle ķåûkisis, ta iêsim vakara vêżot! Jeros), bet arī tautas ārstniecībā pret čũsku kodumiem ( $k a$ ir iêkuôds čũsk, ta jâsalas var̂di un jâliêk virsa, kamat vấd vaī nuôst nepaliêk, ta i jipt izvilkc. pirmaš vấd $i$ uz viêt beîkc Svētciemā), ka varžu kurku|os mazgājuši seju, lai neiedegtu saulē (nagies kur̃kuluôs bệrni mazgâjja mutî, laī nẹnuôdesg Nīcā), ka vardes liktas pienā, lai tas nesaskābtu (zale vâ:rd lik iêkš piẽna, le nesaskâpst tas piēns Popē) un ka bērni ir mācīti - nemocīt vardes (namùk vấrd'iv'is'! t'ềt'e vòi mama nùm'ier's'! Varakןānos).

3. Izlokšṇu leksikas ilustrācijai paretam LVDA komentāros ir iek/auti tautasdziesmu fragmenti, retāk parunas, sakāmvārdi, kas regiistrēti izloksnē un kuros saglabājies lokālais resp. senākais jēdziena, parādības, priekšmeta u.tml. nosaukums, piemēram, tàu'enoîs nùz'el̂t'ieju k'ế zaltona klova lopa Nautrēnos (LVDA 4 A); iva b'eja smùordàm loba, na b'it'äi madu n'äs't' Aglonā (LVDA 14); kẹkatīnas iêlaîdušas stahi mazas avefinas Bārtā (LVDA 50); rakstâ situ sprigulîti maîzes tệ̃a piẽdârbâ Vecpilī (LVDA 58); pệrkuona tẹvâm devini dệli trîs spêra, trîs rûca, trîs zibinâja Grobiṇā (LVDA 85); thâlu

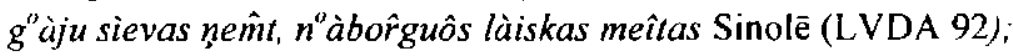
uôbùls nu uôb'èl'n'ícas tuôl'i nazav'èl Vilakā (LVDA 1).

Tādējādi LVDA komentāros ar noteiktu atlasi ir ietverti izlokšņu tekstu fragmenti, kas ne tikai sniedz papildinformāciju par konkrēto leksēmu resp. reāliju, parādíbu un jēdzienu, bet var būt izmantojami kā turpmākos valodnieciskos pētîjumos, tā arī citās zinātṇu nozarēs. 


\section{SAIİSINĀJUMI}

LEV - Karulis $K$. Latviešu etimologijjas vārdnīca. -R., 1992. - 1.-2. sēj.

LLVV - Latviešu literārās valodas vārdnīca. - R., 1972-1996. - 1.-8. sēj.

LVDA - Latviešu valodas dialektu atlanta materiāli. (Skaitlis aiz saīsinājuma apzīmē kartes un komentāra numuru "Latviešu valodas dialektu atlanta" leksikas da|ā.)

ME - Millenbahs $K$. Latviešu valodas vārdnīca / Red., papild., turpinājis J.Endzelīns. - R., 1923-1932. - 1.-4. sēj.

Sehwers - Sehwers J. Sprachlich-kulturhistorische Untersuchungen vornehmlich über den deutschen Einfluss im Lettischen.

Leipzig, 1936.

ЭСРЯ - Фасмер М. Этимологический словарь русского языка. - Москва, 1964.-1973. - T. $1-4$.

dial. - dialektu

ig. - igauņu

Iv. - lejasvācu

kr. - krievu

vlv. - viduslejasvācu

\section{FRAGMENTE MUNDARTLICHER TEXTE IM DIALEKTALEN ATLAS DER LETTISCHEN SPRACHE \\ Zusammenfassung}

Der lexikalische Teil des Dialektalen Atlasses der Lettischen Sprache ist der erste umfangreichere Beitrag zur Erforschung der Dialekte des Lettischen unter geolinguistischem Aspekt. 
Im Unterschied zu den in den letzten Jahrzehnten in Nachbarländern erschienenen Atlanten der Lexik, z.B. zum Atlas des Litauischen und zum Atlas des Weißrussischen, enthält der Dialektale Atlas der Lettischen Sprache mehr illustratives Material - Fragmente mundartlicher Texte: Sätze oder Teilsätze.

Im Artikel werden sprachliche und extralinguistische Faktoren erwähnt, die die Auswahl mundartlicher Texte bestimmt haben; zwecks Illustration sind mehrere Beispiele geboten. 


\section{Benita LAUMANE BRAUCĪT UN CITI TAUTĀ LIETOTIE MASĀŽAS PAN̦ĒMIENU NOSAUKUMI}

19. gs. beigās "Dienas Lapas" etnogrāfiskajā pielikumā publicēti padomi un skaidrojumi tautas ārstniecības materiālu vācējiem,' kā arī paši materiāli - praktiski padomi, ieteikumi saslimšanas gadījumos un ticējumi, kas novēroti dažādos Latvijas novados (Jūrkalnē, Kursīšos, Tīnūžos u. c.). ${ }^{2}$ Apzināmo jautājumu loks ir plašs: ārstnieciskie augi un no tiem gatavotās zāles, dažādi tautas līdzek]i pret čūsku kodumiem, kaulu un zobu sāpēm, kārpām, tūkumiem, ādas izsitumiem, ēdēm, locekḷu sasitumiem, sastiepumiem, mežğìjumiem u. tml.

Etnogrāfisko ziñu krājējs A.Alksnis aizrāda arī uz dažiem apstāk|iem, kas apgrūtina tautas ārstniecības un higiēnas zinātnisku izpēti. Ar ārstniecību saistītie nosaukumi un apzīmējumi, resp., termini tautā sastopami ar vairākām nozīmēm (piemēram, vārdu tūsks lieto trīs atšksirīgu slimību apzīmēšanai), ${ }^{3}$ tādē] ārsts dažreiz nebūt nevar saprast zemnieka slimības tēlojumu" 4

Sevišķa uzmanỉba, pēc A.Alkšña domām, pievēršama tām ārstnieciskām metodēm, ko veic bez zālēm, kā, piemēram, "braucīšanai" un "svecīšu likšanai", jo šo ārstniecisko procedūru aprakstos atrodami zelta graudi ne vien ārstniecỉbai, bet arī tās kultūrvēsturiskai attīstīibai. ${ }^{s}$

'Alksnis A. Dažas piezīmes tautas ārstniecības materiālu krājējiem // Etnogräfiskas ziņas par latvieŠiem, II. - "Dienas Lapas" pielikums. 1892. - R., 1892. - 130.-136. lpp.

2 Etnogrāfiskas ziṇas par latviešiem, Il. - R., 1892. - 9.-11., 56.-57., 133.-136., 147.-150. 161.-167. 186.-187. Ipp.

${ }^{3}$ Alksnis A.: turpat, 130.-131. Ipp.

${ }^{4}$ Turpat, 131. lpp.

${ }^{5}$ Turpat, 133. Ipp. 
A.Alkšña pieminētā braucīsana ir viens no masāžas paṇēmieniem. "Man tika sacīts, ka braukot iesākot no kāda locek|a gala un aizbraukot līdz nabai. Naba uzskatīta itin kā kāds viducis, uz vinu aiziet visi rokas braucieni "7

Latviešu tautas ārstniecībā masāža parasti veikta kopā vēl ar citām ārstnieciskām procedūrām un tautas dziedniecỉbas līdzek|iem, piemēram, pirtī pēršanos, "krūziņu vai podinu likšanu"8 un svecī̌su likšanu. ${ }^{9}$

Latviešu tautas ticējumos iek]auts plašāks apraksts no Blīdenes: parasti masāžu veikušas gados vecăkas sievietes, "kuŗas pagastā tam nolūkam vien stāvēja; viṇas nodarbojās arī ar svecīšu likšanu, ragu likšanu, asins un dē|u laišanu. Kad kāds bija "saraustījies" jeb "nabu atstiepis", tad izkurināja pirti un tūlî̀t nosūtīja pēc braucītājas. Slimniekam vajadzēja kāpt lāvā,

6 "Masāzaza (fr. massage < gr. massein 'glaudīt, mīcīt') dažādi pañēmieni (manipulācijas), ar kuriem masiera rokas vai speciāli aparāti mehāniski vai reflektoriski iedarbojas uz audiem vai orgāniem." (Populārā medicīnas enciklopēdija. R., 1985., 295.) Izšł̧ir vispārēju masāžu (masē visu ḳermeni) un vietēju masăžu (masē tikai kādu kermeṇa da|u). Masāžu lieto higiēniskā, ārstnieciskā un profilaktiskā nolūkā, arī sporta medicīnā. Masāžas iedarbība uz cilvēka organismu ir vispusīga (LPE VI 475).

Sal. masā̇̇a 'sistemātiska mehāniska iedarbība uz cilvēka ķermeña, tā dalu virspusi ārstnieciskos vai higiēniskos nolūkos, izmantojot speciālus pañēmienus' un masēt 'izdarīt masāžu (cilvēkam, tā kermeña da|ai)' (LLVV V I01).

${ }^{7}$ Alksnis $A$. Tautas medicīna // Etnogrăfiskas ziṇas par latviešiem, II. R., 1892. - 163. lpp.

8 "Krūzinas lika itin visur, uz muguras, gūžām, pleciem, uz vēderu. Uz nabu uzlika arvien vislieläko podu .." (Turpat, 164. lpp.)

9 "Svecīsu likšanu izdarīja braucītāja.. Izgrieza labu cietu maizes garozu ar apa|u caurumu vidū, uz kuras tad visapkārt uzlipināja 4-6 vaska svecītes. Visas svecītes aizdedzināja un uzlika slimniekam uz nabas; svecītēm virsū uzspieda alus glāzi. Tā jāva vinām stāvēt kādu stundas laiku. Pēc izdarītās likšanas slimnieks juties spirgts un vesels." (Blïdenē LTT IV 1792). 
neema slotu rokā, labi izpēra un tad sāka braucīt. Papriekšu sāka no kakla, tad braucīja citus locek]us un vispēdīgi vēderu. Kad slimnieks bija izbraucīts, tad vidu nosēja ar jostu. Vēderu braukot, to arī vārdoja ar vidus vārdiem." (LTT 1004).

Masāžu izdarīja arī pēc dzemdībām ("Bātene māti izbrauka, nomazgā .." Raṇķos LTT Ill 1455).

Par to, ka masāža bijis tautā plaši atzìts dziedniecisks pañēmiens, liecina latviešu folklora: piemēram, pasakā no Skrundas vēstīts, ka ar braucǐšanu izdziedē slimo, ${ }^{10}$ bet pasakā no Džūkstes - ka atdzivina pat mirušo. "

Zināšanas par tautas dziedniecības terminologiju īpaši svarīgas dainu tekstu nemaldīgā interpretācijāa, resp., klasifikācijā, sal.:

\section{Saiminieku meitiņami \\ Spaju krekli mugurā; \\ Visus linus atdevušas \\ Par vēdera braucīšanu.}

(Kurzemē LD 20536, 8).

Dainas, kurās minēta (vēdera) braucīšana, registrētas Dursupē (Talsu apriṇk̄ī), Džūkstēe, Mežotnē, Stendē un Ventspilī (sk. LD 20536, 2, 7 v).

Ar šo pašu nozīmi dainās sastopams arī apzīmējums (vēdera) braucījums, sal.: Līziṇai, māsiṇai,

Diega zekses kājiñā;

Villātnās atdevuse

Par vëdera braucījumu.

(Saukā LD 20536).

10 "Slimniece kunkstēja, vaidēja, bet Šĩ labinās klāt: kas kaišot?

"Tā un tā - spiež tîri nost, cik nelabi."

"Ai, tā maza lieta! drusku tikai nobraucī̌su - būsi vesela."

Un tiešăm: līdz labi nobraucīja, palika vesela." (Pas. VIII 45).

11 "Nekas," lapsa pamāca, "sūc tu, vilcinn, no pakauša nelāgās asinis ārā; pūt tu, lācît, nāsīs dvašu; es braucîsu loceklus.."

Un nu vilks sūca, lācis pūta, lapsa braucīja.. nebij ilgi - brālis dzīvs un vesels." (Pas. III 338). 
Dziesmu varianti fiksēti Blīdenē, Rudbāržos un Sesavā (LD 20536, 2).

Kā masāžas paṇēmiens braucīšana līdzinās berzēšanai, aizrädījumi par to atrodami 18. gs. avotos. "Latviešu Ārste"” (1768) šai sakarā dots padoms: "Lai tā braucišana un berzēšana ne tik nikni notiek! Lai tā pārsvīšana mērena paliek!" (LĀ 23).

Ar nozīmi 'berzêt, (ar roku) novilkt, pieskarties, resp., masēt' vārds braucīt un braukt minēts jau 17. gs. avotos: sal. braukt 'fahren; streiffen' (Lettus 1638, 178) un braukt 'fahren; streichen', nobraukt 'abstreiffen, abstreichen', nobraucit 't. p.' (Für. I 45, II 77), braucï 'den Leib abstreichen' (L 1773, 63), vêderu braucĭt, arī vēderu nobraucīt 't. p.' (St. 1789 I 27, U 1872, 36).

Mūsdienu latviešu literārajā valodā vārdu braucīt lieto ar nozīmēm 'berzēt (ar plaukstu); glaudīt; vilkt, raut' (LLVV II 114), nozīme 'masēt' reg̀istrēta galvenokārt tikai izlokšņu vārdnīcās: sal. bràucīt 'zur Heilung streichen, massieren (namentlich in der Badstube)': luocekJus, vẹderu, vīveles braucīt; gudras vecenītes vājiniekus uz lāvas maigi pēra, braucija un laistīja; braucīties 'sich streichen' un brauciens 'das ein malige Massieren' (ME I 325); sal. arī braucāt '(eine kranke Stelle) heilend (be)streichen' Sērenē (ME I 325), izbraucît 'ausmassieren' Saikavā (EH I 435).

Arī jaunākos avotos vārda braucīt nozīme definēta līdzīgi: sal. brañcīt 'berzēt ar plaukstu (parasti kādu ḳermeņa da|u); masēt' Ērg̀emē (ĒIV I 182), bràucît 'berzēt, masēt' Kalupē (KIV I 187).

Pēc izlokšņu leksikas dotumiem, ${ }^{12}$ vārds braucĩ 'masēt' sastopams Kurzemē, Zemgalē, Vidzemēe, retāk Latgalē; tas registrēts Baltinavā, Bunkā un Gaviezēe (sal. Ne māte pērusi, ne braucījusi LD 20342 v), Dignājā, Dricēnos, Dundagā, Jeros (bråūk a ruôk kakl. tas jo nāc pe viṇ brảücit mâcites), Kārḳos,

${ }^{12}$ Izmantota Latviešu valodas institūta apvidvārdu vārdnīcas kartotēka. 
Kazdangā, Lubejā (ar tádu dzẹlzi bràucij), Nīcā (tệvân sâpêja

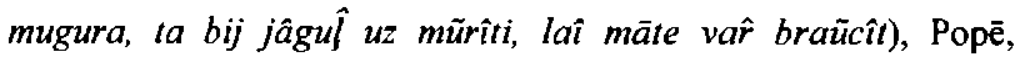
Saikavā, Sinolē, Strazdē (kad kakls sâp, vaîg tik kriêtn bråũcit, ta paliêk làb), Vainižos, Vecatē (braũcija ruôku, kamẹ̃r sâpe pārgäja), Zantē un Ziemerī (Apv.).

No verba braucīt 'masēt' atvasināts darbības veicēja nosaukums braucītājs (braucītāja) 'wer streicht, der Massierer, der Quacksalber' (ME I 325); tas pierakstīts Blīdenē (LTT IV 1792), Jeros (ka atnāc bråũcitaš, ta tũ li uz pirî gäj bråũcites), Kalupē (KIV I 187), Lazdonā, Rencēnos (/ja sāpēja mugura' bràuca pie braūcîtājìm uz muguras braũcîšanu), Svētciemā (agrak joû bi tâdi broücitaji, vẹci vî́ri un siêvi; ta saziẽpej ruôks un broũcij, glumaki iẽt), Valmierā un Vainižos (man bi isslavet broũcitej, mâcej izbroũcit pakrût un vis̄ oûgum Apv.).

Cilmes ziñā braucīt 'masēt' atvasinăts no braukt 'berzt, notraukt (lapas, ziedus; slaucīt asaras)' un tam atbilst liet. braūkti, braukýti ar līdzīgu semantiku (ME I 325, EH I 238, LEV I 142); arī lietuviešu izloksnēs vārds braukýti registrēts ar nozīmēm 'berzēt, masēt' (LKŽ I 1011). Nozīmju attīstība latviešu valodā: braukt 'berzt' $\rightarrow$ 'braucît, traukt' $\rightarrow$ 'š|ūkt, slidināt' $\rightarrow$ 'braukt (ar transporta līdzekli)' (sk. LEV I 142).

Līdzīgi semantiski procesi vērojami vārdam brucināt 'burzīt, berzēt; asināt' (tās pašas cilmes brukt, braukt, braucît ME I 338, 339), kam reǵistrēta arī nozīme 'masēt' Aizvīḳos (EH I 244).

Par nozīmes attīstību 'berzēt' $\rightarrow$ 'masēet' liecina arī vēl citi piemēri. Dainās lĩdzās vārdu savienojumam par vēdera braucījumu vai par vēdera braucīsanu sastopami arī germāniskas cilmes atvasinājumi dziesmās no Zieme|kurzemes: sal. par vēdera strīkuojumu Alsungā, par vēdera strīkējumu (LD 20536, 2 v, EH II 589) un par vêdera strîkēšanu Ancē (LD 20536, 2 v). 
Vàrds strīkēt 'masēt' fiksēts arī 19. gs. rakstu avotā (sal. v. streichen - braucīt, strīkeet, laitīt U 1880, 678). Izloksnēs vārdu strīkēt sastop ar nozīmēm 'berzt; līdzināt, darīt gludu; asināt' (vārds aizgūts no vlv. striken, sk. ME IIl 1091, ËIV IIl 447), sal. strīkēties 'sich reiben' Džūkstē, Lizumā, Raunā, Vārkavā u. c. (LD 20887, ME III 1091).

Masāžā $k \bar{a}$ vienu no pañèmieniem mēdz lietot arī knaibīšanu: sal. knaibīt 'vairākkārt kniebt; sāpīgi kairinăt (par vēju, salu)' (LLVV IV 279). Par šī paņēmiena izmantošanu tautas dziedniecỉbã liecina folklora: "Gan rauga pakausi knaibīt, nosiet, appūst, gan izmocãs šā, gan tā - nel̄̄dz." (Saleniekos Pas. VIII 405).

Par citādu masēšanas paṇèmienu (pretstatā berzēšanai vai knaibišanai) - masēšanu ar lēnām, maigām roku kustībām norāda dainās sastopamie apzīmējumi, kas atvasināti no verba glāsĭt, resp., glāstăt 'glaudīt', sal.:

Māminai bij divas meitas,

Abas divas amatnieces:

Viena visu vecākā,

Tā bij tauku pūtējiṇa;

Otra visu jaunākā,

Tā vēdera glāsītāja.

(Rencēnos LD 20911).

Dziesmai registrēts arī variants ar îsu patskani vārda saknē: sal. (vệdera) glasītāja (LD 20911, EH I 391).

Kādā citā dainā atrodams vārdu savienojums par vēdera gläsījum(u) Rencēnos (LD 20573), kas liecina, ka lietojums nav nejaušs.

Vārds glāsīt 'glāstīt' sastopams Lietuvas pierobežā, piem., Nìgrandē un Vidzemē Āraišos, Jaunrozē, Rankā, Vecpiebalgā u. c. (ME I 623, EH I 392). Tas minēts jau 17. gs. rakstu avotos (sal. glāsīt, glāstīt 'streicheln' Für. I 81, II 133), bet glasīt sastopams 19. gs. avotos ('streicheln, mit der Hand sanft überfahren, reiben' U 1872, 75). 
Cilmes ziṇā glāsīt (glasīt), glāstît 'glaudīt' atbilst liet. glóstyti, glósti 'slīpēt, gludināt', glodùs 'gluds', pr. glosto 'galoda' (ME I 623, LEV I 299); no verba atvasināts arī darbïbas veicēja nosaukums glāsītājs, glāsîtāja (glāstītājs, sal. liet. glóstytojis).

Otrs latviešu valodā izplatîtākais vārds ar nozīmi 'masēt (dziednieciskos nolūkos)' ir laiñ; tas minēts arī "Latviešu Ārstē", aprakstot tautā iecienītās ārstnieciskās procedūras: "Sāp vēders un pakrūts, tad bāba virsū nāk laitīt. Kad vēdera graize, tad pārkariski jāgul jeb pods nabā tiek likts, lai tas ievelkas, lai tas sarežgetu nabu atšḳetina" (LĀ 13).

Vārds laitīit 'masēt' sastopams jau 17. gs. rakstu avotos, sal.: kaulus laita ar slotas kätu (Mance)a Postilas II 262, ME II 414), laitīt, izlaitīt, nolaitīt 'in der Badstuben abstreichen' (Für. I 122, II 198). Vēl citi vārda laitīt atvasinājumi un nozìmju precizējumi atrodami 18. un 19. gs. vārdnīcās: sal. nolaitīt 'den Leib abstreichen' (L 1773, 212), laitināt vēderu 'den Bauch abstreichen' (St. 1789 I 132), laitīt 'sanft mit der Hand hin und her fahren' (U 1872, 134). Mūsdienu literārajā valodā to lieto reti (novec. LLVV IV 584).

P.Šmits norāda, ka laitīt senāk mācēja gandrīz katra vecāka sieviṇa un ar laitīšanu lūkoja dziedēt dažādas hroniskas kaites: kaulu sāpes (reimatismu), stīvus locek|us, nespēku un pat trieku (Raunā LTT III 1004).

Laitǐšana pieminēta arī dainās:

Tā sēd Dārtiña

Kā veca kaķe:

Ne mäte pērusi,

Ne laitijjusi.

(Sidgundā, Lejasciemā LD 20342).

Atalgojums par masēšanu jeb vêdera laitijumu nav bijis dižs: cimdu pāris, zeḳes vai tml. (LD 16773, 7), sal.:

Panāksniṇu meitingām

Mellas zeķes kājiñās;

Baltas zeķes izdevušas 


\section{Par vēdera laitījumu.}

(Bruknā, Misā LD 20536, 7).

Ar nozīmi 'masāža' vārds laitījums reǵistrēts Galgauskā (LD 20536 v), Kliğenē (LD 20536, 5), Meirānos (sal. par vēdera leitijumu LD 20536 v) un laitējums 't. p.' Viškos (sal. par vàdara lait'èjumu LD 20536, 3). Dziesmas variantā laitīšana minēta no Jaunlaicenes (sal. par vēdera laitǐšanu LD 20536, 6 v).

Masāžas veicējs ir laitītājs, laitîtāja. Un arī šie nosaukumi sastopami dainās, sal.:

Kur palika panāsnu

Skaistās meitiñas?

Aizgāja pirtī laitīties.

Viens vecs tēvīts

Ūdeni bringèja,

Viena veca māmiña

Laitītāja..

(Valmierā LD 20896).

Tā Dārtiṇa lielījās,

Veselīga mātes meita;

Māte kuili nojādīja,

Laitītājas meklēdama.

(Sidgundā, Viskā|os LD 20338).

Vārds laitütājs registrēts arī Vietalvā (LD 20338 v), laitētājs Višksos un Daugavpils apkaimē (.. mòt'ẹ brauc'ẹ, lait'étòju makládama LD 20133), vēdera laitītājs Dūrē (sal. vēdera laitītāji LD 18309), Galgauskā (sal. Lìdzi gāja sāls pūtēji, I vêdera laitītāji LD 20998).

Ar izskanu -ikis (izloksnēs atvasina deminutīyus bez maiguma nokrãsas vai pejoratīvas noz̄imes vãrdus, sk. Lgr. 358, 359; Latv. dial. 199) darinātais laitiksis registrēts tautasdziesmā, sal.:

Brā|am braucu vedējos,

Gara krekla gribēdams:

Man iedeva cimdu pāri 
Kā vēdera laitiķim.

(Lieljumpravā LD 25456).

Pēc izlokšṇu dotumiem, vārda laitīt un tā atvasinājumu areāls ir Vidzeme, Augšzeme un Latgale: làitīt 'masēt' registrēts Smiltenē (ME II 414), Nītaurē; làitīt ${ }^{2}$ Aknīstē, Bērzgalē, Druvienā, Lubejā, Praulienā, Saikavā, Varakłānos (ME II 414, EH I 715), Kalupē (arî nùolàitît, palàitît, salàitît KJV 】 552); laitināt Smiltenē (ME II 414); làitêt ${ }^{2}$ Dricēnos un Nautrēnos (ka suôp'à rùka vòi placs, b'eja bùobys, kas prota lab'i làit'ât' Apv.); aplaitīt Praulienā (visa miesa jau aplaitīta EH 1 97); izlaitīt Lizumā (izlaitît kādam muguru EH I 461); salaitīt Galgauskāa (salaitīt kādam muguru ME III 666).

Deverbālie atvasinājumi: làitikisis ' 'masētājs' Lizumā (ME II 414); làitütājs ${ }^{2}$ 't. p.' Iršos, Nautrēnos un Saikavā (Apv.); laitinis 'ein Kranker, der massiert werden muss' Bērzgalē (EH I 715), kam blakus ar vārda nozīmes pārnesumu sastopams arī laitinis 'Mummel' Zvirgzdenē (ME II 414; ir norādes jau no 18. gs., ka masēšana notikusi vienlaikus ar vārdošanu, sk. LTT II 1004).

Pēc J.Endzelīna uzskata, laitīt saistāms ar liet. lytéti, liêsti 'skart, aizskart, aiztikt' (ME II 414). K.Karulis laitīt 'masēt' saista ar laist 'virzīt (slīpi) uz leju' $\rightarrow$ 'slidināt' $\rightarrow$ 'glaudīt, masēt' (sk. LEV I 493). Minētā masāžas panēmiena apzīmēšanai abi skaidrojumi ir motivēti un ticami.

Blakus verbam lait̄̄t un tā atvasinājumiem dainās sastopami arī varianti, kas atvasināti no verba lais $\bar{t}$ (sal. 'liet ūdeni; masēt' ME II 413): laistījums 'masāža' Kastrānē (sal. garas zeķes izdevušas par vēdera laistījumu LD 20536, 4 v), laistīsana 't. p.' Birzgalē (par vēdera laistīšanu LD 20536, 7), laistītāja 'masētāja' Mēdzūlā un Stukmaṇos (LD 20338 v, ME II 413).

Cilmes ziṇā, kā norāda K.Karulis, laistīt 'masēt' saistāms ar laitît; laistīt 'masēt' radies kā homonīms blakus vârdam laistīt 'liet ūdeni' (LEV I 494). Parasti homonīmiem ir tendence zust, īpaši ja tie var radīt pārpratumus (un pārpratumi 
dziedniecībā var k|ūt liktenīgi). Homonīma laistīt 'masēt' pastāvēšanu, saglabāšanos ietekmēja situatīvās asociācijas: masēšana notika pirtī un dziedināšanā izmantoja arī ūdens procedūras (sal. atlaistīt pamirušu 'einen aus der Ohnmacht ermuntern, welches siet mit Begiessung kalten Wasser thun' L 1773, 35, St. 1789 I 132).

Vidzemē un Augšzemē ar nozīmi 'masēt' sastopams arī vārds làicīt 'streichen, massieren' Lubejā, Neretā (ME II 401), Cesvainē (EH I 711), sal. laicīt 'abstreichen' Rīgā (U 1872, 134) un laicijums 'masāăa' Taurupē (par vêdera laicījumu LD 20536, 4).

Vārda cilme nav îsti skaidra: pēc J.Endzelīna uzskata, laicīt 'masēt; taupīt; sargät; vilcināt' saistāms ar latv. likt, liet. laikýti 'turēt, glabāt, ievērot', pr. laikūt 'laisten, gehalten' (ME II 401, DI IV 2 248, sk. arī Toporov 1990, 21, PKEZ̆ III 23). Citādi vārdu laicīt 'masēt' skaidro K.Karulis, pielaujot fonētisku pārveidojumu $c<t$ (sk. laitīt LEV I 494).

V.Toporovs norāda uz baltu vārdu (liet. laikýti, pr. laiküt) iespējamo radniecỉbu ar dziedniecības terminu *lečiti slāvu valodās (sk. Toporov 1990, 23). Tādā gadījumā latviešu valodā vărdam laich̄t 'masēt' saglabājusies arhaiskā, ar dziedniecîbu saistītā nozīme.

Ar nozīmi 'masēt' Vidzemē un Latgalē sastop arī vārdus şlaucīt un šlaukāat, arī šlaukt: sal. šlaucìt 'streichend glatt machen; streicheln, massieren' Bērzaunē (ruoku š̉aucīt) un Druvienā (muguru šlaucīt ME IV 65), Skaistā un Varak|ānos (šlaûcīt - slimu pakrūti ar siltu üdeni un ziepēm glaudīt EH II 644), šlaukāt 't. p.' Vestienā (uzpūstu vệdẹru vajaga labi şlaukāt, tad paliks slābans ME IV 66), šlàukt ' 'atkārtoti braucīt, berzēt vienā virzienā' Nautrēnos (tấ šlàuc'ä ài rùkòm pàr mugoru Apv.).

Verbam šlaukties registrētas nozīmes 'glausties, vilkties' Alūksnē u. c. (EH II 644), sal. šlaukt 'lodzìties' (ME IV 67) un šlaucît 'lēni staipīt (kermeni, tà da|as)', šllaucīties 'lēni staipīties; atpūsties (parasti gulus stāvoklī)' (LLVV VIl ${ }_{2} 387$ ). Cilmes ziṇa 
tie saistāmi ar $\check{s} \mid \bar{u} k t$ 'virzīties pa virsmu, nepārtraucot saskari ar to.., slìdēt' (LLVV VII 2 389, LEV Il 362). Nozīmju attīstība: šlaukt 'šlūkt, slīdēt; slidināt, š|ūcināt' $\rightarrow$ 'masēt (ar slīdošām kustībām)'

Lìdz šim aplūkotie masāžas termini atvasināti galvenokārt no divām vārdu grupām ar pretējām nozīmēm: 'berzēt; brucināt' un 'glāstīt; (maigi, viegli) aizskart; slidināt' Par trešo izplatītāko dziednieciskās masāžas paṇēmienu liecina vārda spaidnt semantika: sal. spaîdñt 'vairākkārt spiest; vārdojot masēt, lai ārstētu (slimību, slimo ķermeña dalu)' Érgemē (ruōzes gāja pie vecenẽm spaîdîtu. dzirkstes gãja spaîdîtu /govij tesmeni/ spaîdija a iskapc strị̂ējamuô galuôdĩnu, sk. ẼIV III 401), sal. vẹederu spaidīt 't. p.' (U 1872, 271, ME III 980). Vidzemē registrēti arī vairāki atvasinājumi: apspaîdît 'spaidot apvärdot' Ėrgemē (.. a tiēm vàdìm apspaîda ruõžu vaĩni tuõs vâjumus - ruõzes un aûguōnus apspaîda ĒIV I 84), apspaidīt slimniekus (ME I 124); nùospaîdīt 'spaidot apvārdot' Ēiǵemēe (/vārdotājs/ puiku nùospaîdija, jàu puika vàr rùoku kustinât ĒIV II 458) un spaîdities 'likt sev ko vārdojot masēt' (ẼIV III 402).

Ar minēto masāžas paṇēmienu saistāmi arī vairāki ticējumi šai apvidū ("Sāpošā vieta jāapspaida ar ratu tapu, kas atrasta uz cela.. tad sāpes tūlīt mitējas." Drustos LTT III 1606; "Slimam bērnam vajaga pieri ar maizi un kājas ar gaḷu apspaidīt.." Smiltenē LTT I 181).

Masāžas paṇēmiena īpatnības - spiedienu izmantošanu tēlo arī dainas, sal.:

\section{Viena veca māmiṇa}

Laitîtāja;

Uz vienu spiedienu

Pusdālderī̌sa,

Uz otru, uz trešu

Veselu dālderi.

(Valmierā LD 20896). 
No verba spaidît atvasināts darbības veicēja nosaukums: spaîdîtäjs, spaîdîtāja ('wer kurierend streicht und knetet' U 1872, 271; aicināja palīgā spaidütäjas, kas prata dziedināt ar ipašiem püšsamiem vārdiem ME III 980), Valkā ('wer eine kranke Stelle mit der Hand drückt und bespricht' EH II 544), Ërgemene (ĒIV III 402), Vainižos (Apv.).

Tautas dziedniecibas terminu spaidīt, spiediens, spaidītäjs kontekstā saprotams $\mathbf{k} \mid \bar{u} s t$ arī apzīmējums liesas därējs, kas minēts kādā dainā no Suntažiem:

Ta Annina nevesela,

Sevī vien lūkojās.

N̦em, bāliṇ, līko ḳēvi,

Brauc pie liesas dūrējiña.

(LD 20339).

Lai gan dainā jaušama ironiska attieksme, taču tautas dziednieka aprakstošais nosaukums liesas dūrējs, resp., dūrējiņš darināts līdzīgi kā vìvelu dūrējs 'dziednieks, kas ārstē vīveles (lopu slimibu)' (sal. 'der Wunderarzt, der stechend die Feifel kuriert' ME I 529). Vīveles ārstēja galvenokārt ar vārdošanu; sal. tekstu no Ërgemes: vīeles jàu tik cũkãm ùn zirgìm mẹtâs. vĩveles, tãs kaklu spiêżuõt ciê. agrâk jàu tãs a burim viê ästẽja. nùovàduōja. palũdzẽja vĩvelu vàdi (ĒIV III 742). Savukărt medicīnā (diagnostikā) liesa un liesas palielinăšanās ir vairāku slimibu pazīme.

Sal. durt 'badīt, stipri spiest (ar pirkstu, asu priekšmetu); caurumot', liet. dùrti 'durt, badīt; diegt' (sk. ME I 520, LEV I 242, ĒIV I 289).

Nobeigumā. Latviešu valodas izloksnēs un folklorā (dainās, pasakās un ticējumos), kā arī rakstu avotos ar nozīmi 'masēt (dziednieciskos nolūkos)' sastopama virkne verbu: sal. braucìt, braukt, brucināt, durt, glästīt, glāsīt (glasìt), knaibīt,

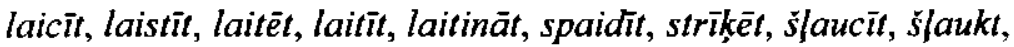
şłaukāt. Vairākiem darbību nosaukumiem blakus registrētas arī refleksīvas formas (braucüties, laitïties $\mathrm{u}$. c.) vai atvasinājumi ar 
priedēkliem ap-, iz-, nuo-, sa- (piem., izbraucīt, nuobraucït; aplaitīt, salaititit).

Darbỉbas veicēja (dziednieka, masiera) nosaukumi parasti atvasināti ar piedēkli -tāj- no atbilstošā verba (piem., braucîtäjs, laitītājs, spaidītäjs), retāk sastopami atvasinājumi ar piedēk|iem -ēj-, -ik-, -in- (piem., dūrējs, laitikis, laitinis); fiksēti arī citi deverbāli atvasinājumi ar piedēkliem -ien-, -šan-, -um(piem., brauciens, spiediens; braucišana, laitīsana; laitījums, strikêjums).

Semantiskā aspektā masāžas paṇēmienu nosaukumiem pamatā ir galvenokārt darbỉbas vārdi ar nozīmi 'berzēt, braucît' vai 'glāstît, glaudīt', vai arī 'spiest, spaidīt', retāk - 'kniebt, knaibīt' Pamatnozîme 'masēt (ar vieglām kustībām)' ir tikai verbam laitït (laitêt), ar šo nozīmi vārds minēts jau 17. gs. rakstu avotos; pãrējiem verbiem nozīme 'masēt' ir sekundāra.

Kã liecina minēto masāžas nosaukumu semantika un vārdu geogrāfiskā izplatî̉ba, tautas dziedniecīiā jau no seniem laikiem bijuši pazīstami dažāa masāžas paṇēmieni (Vidzemē lietoti vismaz trīs paṇēmieni).

Cilmes ziñā aplūkotie masāžas nosaukumi ir mantoti vārdi (izṇemot germānismu striḳêt).

\section{AVOTU UN LITERATŪRAS SAİSINĀJUMI}

Apv.

DI

EH

ĒIV
Latviešu valodas institūta apvidvărdu vārdnīcas kartotēka.

- Endzelins $J$. Darbu izlase. Četros sējumos.

R., 1970-1982. - 1.-4. sēj.

- Endzelīns J. Hauzenberga E. Papildinājumi un labojumi K.Mĩlenbaha Latviešu valodas vărdnīcai. - R., 1934-1946. - 1.-2. sēj.

Kagaine E., Raǵe S. Ërgemes izloksnes vārdnīca. - R., 1977-1983. - 1.-3. sēj. 
Für. I, II

KIV

$\mathrm{L}$

$L \bar{A}$

Latv. dial.

LD

Lettus

LEV

Lgr.

LKZ̆

LLVV

LTT

ME

Pas.

PKEŽ

St.
- Fennell T.G. Fürecker's dictionary: the first manuscript. - R., 1997; Fürecker's dictionary: the second manuscript. - R., 1998.

- Rekēna $A$. Kalupes izloksnes vārdnīca. - R., 1998. - 1. sēj. (A-M), 2. sēj. (N-ŽZ).

- Lange $J$. Vollständiges deutschlettisches und lettischdeutsches Lexicon. - Mitau, 1773-1777.

Vilde P.E. Latviešu Ārste / Jākoba Langes 1768. gada tulkojuma teksts. - R., 1991.

- Rudzīte $M$. Latviešu dialektolog̉ija. - R., 1964.

- Barons K., Visendorfs G. Latvju dainas.

Jelgava; Pēterburga, 1894-1915. - 1.-6. sēj.

- Fennell T.G. A Latvian-German Revision of G.Mancelius' Lettus (1638). - Melbourne, 1988. Karulis $K$. Latviešu etimolog̉ijas vārdnīca. Divos sējumos. - 1992. - 1. sēj. (A-O), 2. sēj. $(\mathrm{P}-\check{Z})$.

- Endzelīns $J$. Latviešu valodas gramatika. - R., 1951.

Lietuvių kalbos žodynas. Vilnius, 19681997. - T. I-XVIII.

Latviešu literārās valodas vārdnīca. R., 1972-1996. - 1.-8. sēj.

- Šmits P. Latviešu tautas ticējumi. - R., 19411944. - 1.-4. sēj.

Millenbahs $K$. Latviešu valodas vārdnīca / Red., papild., turp. J.Endzelīns. R., 19231932. - 1..-4. sēj.

Latviešu pasakas un teikas / Sakopojis un redigèjis P. Šmits. - R., 1924-1940. - 1.-15. sēj. Mažiulis $V$ Prūsu kalbos etimologijos žodynas. - Vilnius, 1988-1997. - T. 1-4.

- Stender G.F. Lettisches Lexicon. Mitau, 1789. - T. 1-2i 
Toporov

Toporov V.N. Prusskij jazyk. Slovarj. Moskva, 1975 (A-D), 1979 (E-H), 1981 (I-K), $1984(\mathrm{~K}-\mathrm{L}), 1990(\mathrm{~L})$.

U 1872 - Ulmann C. Lettisch-deutsches Wörterbuch. R., 1872. - T. 1.

U 1880 Ulmann C. Deutsch-lettisches Wörterbuch / Bearb. G.Brasche. - Riga; Leipzig, 1880.

\section{BRAUCIT UND WEITERE VOLKSTÜMLICHE BEZEICHNUNGEN FÜR MASSAGETECHNIKEN Zusammenfassung}

In Mundarten und der Folklore des Lettischen (in Volksliedern, Märchen und Glauben) sowie in Schriftquellen lässt sich eine Reihe von Verben mit Bedeutung 'massieren (zur Heilung)' finden: vgl. braucīt, braukt, brucināt, durt, glāstīt,

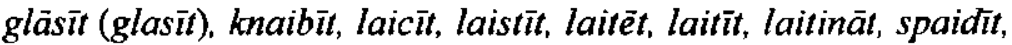
strikkêt, šlaucūt, šlaukt, šlaukāt. Bei mehreren Benennungen von Handlungen sind parallel auch reflexive Formen (braucīties, laitîties u.a.m.) oder Ableitungen durch die Präfixe ap-, iz-, nuo-, sa- verzeichnet (z.B., izbraucit, nuobrauciti; aplaitit, salaititt).

Benennungen der agierenden Person (des Masseurs, des Heilenden) sind in der Regel durch den Suffix $-t \overline{a j}$ - vom entsprechenden Verb abgeleitet (braucītājs, laitūtājs, laitītāja, spaiditäjs u.a.), seltener kommen Ableitungen durch die Suffixe -ejj-, -ik-, -in- vor (z.B., dürëjs, laitikis, laitinis); es sind auch weitere deverbale Ableitungen mit den Suffixen -ien-,-šan-,-umfixiert (z.B., brauciens, spiediens; braucišsana, laitīšana; laitījums, strīkejejums).

Unter semantischem Aspekt liegen den Bezeichnungen für Massagetechniken vorwiegend Verben mit Bedeutung 'reiben, streichen' bzw. 'streicheln, liebkosen' oder aber 'drücken, kneten', seltener - 'kneifen, zwicken' zugrunde. In der Grundbedeutung '(mit leichten Bewegungen) massieren' wird 
lediglich das Verb laitīt (laitēt) gebraucht, mit dieser Bedeutung wird das Wort bereits in Schriftquellen des 17.Jh. erwähnt; bei den übrigen Verben ist die Bedeutung 'massieren' sekundär, obgleich sie nicht immer die jüngste Bedeutung ist (vgl. braukt 'sich mit einem Verkehrsmittel bewegen').

Wie die Semantik der Bezeichnungen für Massagetechniken und die geographische Verbreitung von Wörtern bezeugt, sind in der lettischen volkstümlichen Heilkunst bereits seit alters her verschiedene Massagetechniken bekannt gewesen (in Livland wurden zumindest drei Techniken verwendet).

Hinsichtlich der Herkunft sind die Bezeichnungen für Massagetechniken ererbte Wörter (mit Ausnahme des Germanismus strịkêtt). 


\section{Anna STAFECKA}

\section{VERBI AR NOZĪMI 'RAKT' UN 'APBEDĪT' LATVIEŚU VALODAS IZLOKSNẼS}

Latviešu valodas dialektu atlanta (LVDA) Leksikas dajas materiāli, kas ir bagātīgs izziṇas avots atsevišḳu leksikas tematisko grupu izpētei, piesaistījuši uzmanību vairākkārt.' Arī konkrētais raksts veltīts vienai tematiskai grupai, proti, verbiem ar nozīmi 'rakt' un 'apbedīit', kas atspogu|oti LVDA 99. kartē.

Verbs rakt (sal. liet. ràkti 'stochern, stochernd öffnen, kratzen, stechen' ME III 475) ar nozimi 'durt, parasti lāpstu, zemē un celt, veidot bedri', kā tas skaidrots LLVV $6_{2} 531$, kā vienīgais šìs darbības apzīmêjums pazīstams arī lielākajā da|ā izlokšṇu. Kā sekundāra Latviešu literārās valodas vārdnīcā dota nozīme 'apbedīt, apglabāt', kura pazīstama Latvijas teritorijas lielākajā da|āa, piemēram,

Sk., piemēram, Buśmane B. Édienu nominācija latviešu valodas izloksnēs // LPSR ZA Vēstis. 1986. Nr. 8. 70.-81. lpp. Galertveida èdienu nosaukumi izloksnēs // Latviešu valodas kontaktu pêtijumi. - R. 1987. - 86.-134. Ipp.; Latviešu valodas dialektu atlanta Leksikas da|a - avots vārdu izpētei dažādos aspektos // Vārds un tā pêtī̌sanas aspekti. - Liepāja, 1997. - 22.-29. lpp.; Édelmane I. Augu nosaukumu semantika // LPSR ZA Vēstis. 1986. - Nr. 1. - 85.-95. lpp.; Jansone 1. Dvieja nosaukumu semantika, cilme un areālā izplatiba // VII Starptautiskais baltistu kongress 1995. g. 13.-15. jūnijā. Referātu tēzes. - R. 1995. - 42.-43. Ipp.; Tulznu un varžacu nosaukumi latviešu valodas izloksnēs // LZA Vēstis, 1997. - Nr. 3 / 4.

47.-55. Ipp. Kurzemniece 1. Par vārda sẹta nozīmēm latviešu valodas izloksnês // Linguistica Lettica. 1998. - 2. - 60.-66. lpp. Laumane B. Etīde par krupja un vardes nosaukumu semantiku // Vārds un tā pētīšanas aspekti. Zin. konferences tēžu krājums. Liepāja, 1997. - 33.-34. lpp.; Paegle Dz. Siena grābekla nosaukumi Vidzemē // Velt̄̄jums akadēmiķim Jānim Endzelīnam. 1873. 1973. - R. 1972.

197.-210. lpp. Stafecka A. Leksēmas ēna un pakrēslis latviešu izloksnēs // Baltistica XXXII (1). - Vilnius, 1997. - 77.-81. Ipp. 
kad ta raks - tâ arviẽn prasa Valtaiḳos 39, bệrn' usrakt virŝm Aizputē, aîzgãju par vệlu, bija jau aprakts Džũustē, vinu apraka Zvirgzdinu kapuôs, tajuôs kapuôs visi tiẽ

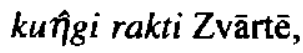
vinu apraka Kaîna kapuôs Kārḳos, es gribu iêt us kapiẽm, ka Bẹrtu raks Kūdumā, Laîcẹnes kopûs mùns vacijs tàus aprokts Mārcienā.

Dažās Vidzemes ziemeju izloksnēs lieto prefiksālo atvasinājumu nuorakt, piemēram,

cits nuôruôk klusinê̂ Duntē,

mãti nuôraka Er̂nīsam lïdzâs Braslavā,

kapsêtê nùorùok Kauguros, arī Vainižos.

Pededzē registrēts verbs (ap)rakti, bet Sē|os adverbiālās konstrukcijas rakt nuôst un rakt nuôstî.

rakt ar nozīmi 'apbedīt' nav raksturīgs Augšzemes un Latgales novadam, izṇemot sporādiskus regiistrējumus atsevišḳās izloksnēs, piemēram, Ābelos, Pilskalnē un dažās Latgales un Vidzemes robežizloksnēs kā Barkavā, Rugājos, Aiviekstē. Kāa liecina izlokšņu materiāli, Augšzemē un Latgalē (ap)rakt var tikai beigtu dzīvnieku, ne cilvēku, piemēram,

kustùoni aprùok Gārsenē,

màitu aprùk, cÿtuàku abglobòi Sakstagalā

sun'i vàr aprakt', cyłvàku globòi Kapiṇos,

arī Nautrēnos pierakstītajā salīdzinājumā:

vòi ta navar'ä pagloboît' k'ê̂ cytvàku, aproka k'êt v'epreît'i 'apglabāja bez mācītāja' Šāds nozīmju šķīrums sporādiski registrēts atseviškās izloksnēs arī citos Latvijas novados, piemēram,

ciliệ̣ku abglabâ, beîktu suni apruôk Tāšos, Medzē,

cilvệku abedî, apglabâ, suni apruôk Ozolniekos, abglabà cillvệku, aprùok kustuôni Ikšķilē, 
cytuàku abglobà, ku:stúeni gòn tikài a:prùok Mārcienā. Atsevišķās Latgales austrumu izloksnēs ar nozīmi 'rakt' lieto vārdu raust, piemēram, dùb'i ràuš Mērdzenē, Škșilbēnos, arī Brigos, Istrā, Kārsavā. LLVV VI 2552 vārds raust dots ar nozīmi 'pakāpeniski virzīt (ko irdenu, izkliedētu), parasti pa kādu virsmu (ar rokām vai kādu rỉku)' Lietuviešu valodā radniecīgais vārds raūsti ir ar nozīmi 'rakt, rušināt, raust' (ME III 488). Etimologiski vārds raust tiek saistīts ar raut, kam pamatā ide. sakne *reu- ar nozīmi 'plēst, plūkt, rakt' (LEV I 109). Dažās izloksnēs vārdu raust lieto arī ar nozīmi 'apbedīt', piemēram,

mani kab apràustu B'iel'ìnskejûs kopûs Šķilbēnos,

itûs kopûs jàu mes ràušamîs Vīksnā,

apràust myrùn'i Pildā.

Jāpiebilst, ka plašăkā areālā Latgales centrālajās izloksnēs vărds raust tiek lietots arī ar nozīmes niansi 'aizbērt kapu', no kā acīmredzot attīstījusies iepriekš minētā vispārinātā nozīme 'apbedīt', piemēran,

z'äm'ä c't̂̌i sasolus'ä, grỳuši b'ie kopu àizràust' Bērzgalē,

paglobùo apràus'ä, iztyka krystu, pučis', vàiņukus Makašēnos,

ka dàuz'i z'ämis' pal'ik, ka dùb'i 'kapu' àizràuś, nabašn 'iks 'mirušais' nàsùt' bèis' skùps Nautrēnos.

Kā novecojis LLVV II 62 ar nozìni 'rakt' dots vārds best (sal. bedre, lietuviešu bèsti 'durt, rakt' ME I 280-281). Tam pamatā ir baltu sakne *bed- 'durt, rakt', no kā besti > best, sīkāku etimolog̀iju skat. LEV I 96.

Kompaktā areālā vārds best sastopams Vidzemes ziemejaustrumos, Latgales ziemelos un austrumos. ME tas dots arī no Kalupes, sporādiski registrēts arī Aizkalnē un Dagdā, piemēram,

dùbi 'bedri' bad Bejavā, kanovu 'grāvi' badòi Vijakā, sl'äpnoîs plovô̂s s'engô̂k b'äd'ä grùovus, lài iûd'in'c' nastùou Nautrēnos, còuka izbaduse bedri Bejā. 
Ar nozīmes niansi 'rakt kapa bedri' vārds best registrēts atsevišşās Vidzemes zieme|u izloksnēs, piemēram,

bredi ruôk bet: iêt kapa bẹst Mazsalacā,

kapa bedri bẹd, citu bedri rùok Sēlos,

kapa bedr bêd, citu bedri rùok Ēvelē.

kapa bedr' bẹ, grãvi rùok; bet: kurmja bẹdakl's Omulos. Pēdējais piemērs liecina, ka vārda best nozīme šajā izloksnē mūsdienās jau ir sašaurinājusies - Vidzemes ziemeju da|ā (izloksnēs ap Jeriem un Naukšēniem) vārdu (ap)best lieto tikai ar nozīmi 'apbedīt, apglabāt mirušo', piemēram,

miruõni bûs best treždiên, lai gan bẹdamã diêna nau

Skaņkalnē,

es seu mât ka nuôbed", neviên virsu: klâjama: drể nebii Ipiķos,

rît jâièt paliḡà apbest, rît man jâiêt bedejuôs 'bērēs'

agrâk teîca Sējos.

manu meît's dêlện ${ }^{u}$ beda tâ'pat bez diêvvârdiem Skaṇkalnē,

ka tùo sàimniēci beda, ta büi daũz cilvēku Ērgemè.

Cilmes ziṇā radniecīgs ir vārds (ap)bedīt (LLVV I 186), kas ir arī literārās valodas vārds. LLVV II 49 kā novecojis dots bezpriedēkla vārds bedīt. Izloksnēs vārds (ap)bedīt vienotu areālu neveido, kompaktāk tas sastopams Vidzemes izloksnēs, nereti ar piebildi, ka tas ir jaunāks vārds, piemēram,

svèdiẽ apbedija vaūâk mirušuõs Dzērbenē,

senâk teîc ${ }^{a}$ paglabât, tagad abbedît Morē,

agrâk bi - rakt, tagad abbedît Ozolos,

abedit - lieto jaun. p. Vecpilī,

bedît, abedìt - tikaî tagad İvandē, Jaunsvirlaukā,

bedît sak" tikầ mâcîtâis İlè.

Vairākās izloksnēs registrēts arī variants apbēdīt, piemēram,

Sileniêk" kapuôs vel daži bêdî Asîtē,

siêvaî naû bij's naûdas pat kuô zãrku nuôpirkt un abêdit

Grobiñā, 
glabât, tagad teîc abbêdît Vaiṇodē,

jåu sèn abbêdejà̀m Sunākstē.

Galvenokārt Latgales dienvidu izloksnēs sastopams verbs kast, kuram atbilst lietuviešu kàsti ('rakt, rušināt' ME Il 169), piemēram,

dùb'i iskas'ä $3^{\prime} i j u$ Aulejā,

vyss tùs m'ežus nùjàm, grùovus sakaš Asūnē,

kopu kaš Aulejā.

EH vārds kast 'rakt' dots vēl no Bebrenes, Vecpiebalgas, kur mūsdienās tas šai nozīmē vairs nav konstatēts.

Vārds kast ar nozīmi 'rakt' sastopams arī Dienvidrietumkurzemē - Rucavā un Dunikā, piemēram, duôbi kaš cilvệ̂kam un rãciniêm Rucavā. Šajās izloksnēs tas acìmredzot ienācis no lietuviešu valodas.

Izloksnēs vārds kast ar nozīmi 'apbedīt, apglabāt mirušo' nav konstatēts.

Vărds kaust 'rakt' (sal. liet. kaũsti), kas ME dots no Vandzenes, bet EH no İvandes un Dundagas mūsdienu izlokšņu vākumos nav konstatēts.

Savukārt tikai ar nozìmi 'apbedīt' izloksnēs sastopami arī vēl citi verbi.

Visplašāk izplatīts ir vārds glabāt, kas ir arī literārās valodas vărds (LLVV 3, 95) un pazīstams visos dialektos. Parasti tas tiek lietots ar priedēkliem pa-, ap- (bez nozīmes škiīuma) apglabāt, paglabāt, piemēram,

nuômiruš liêk zar kâ un apglabâ Rubā,

kapuôs visi trîs paglabâti Ceraukstē,

senuôs laikuôs citâd' neteîc ${ }^{a}$ kâ abglabât Asītē,

paglabā, us kapsễtu àizvẹd aprakt Vecpiebalgā,

mùms vaĩrâk sak : paglabā Lugaži,

abglobuôt àr gùdu vajak kotru cỳtvàku Gaigalavā,

3'iert', ka is kopu 3'ît', làikàm naskù globòi Nautrēnos.

Atsevišḳās Zieme|vidzemes izloksnēs registrēts prefiksālais variants nuoglabāt, piemēram, 
vẹceš nuômi:r, [viṇu] nuôglabein un̂ coür Limbažos, miruôni nuôruôk, nuôglabâ Vainižos, arī Pālē.

Izvērstu värda glabāt cilmes un nozīmju attīstības skaidrojumu devis K.Karulis. Vārds glabāt, kā zināms, etimologiski saistāms ar glābt, pamatā ir ide. sakne ar nozīmi 'aptverot saspiest', no kā baltu valodu nozīme 'aptvert, saņemot abām rokām' un tâlāk latviešu valodā nozīme 'noliekot kur, turēt rezervè vai drošỉbā'(skat. LLVV I 298). Acīmredzot no minētajām nozīmēm tālāk ir attīstījusies arī nozīme 'apbedīt' (skat. ĹEV I 298).

Galvenokārt Vidzemes austrumda|̣̄ā pierakstīts vārds apbērēt, kas ir arī literārās valodas vārds (LLVV I 186), piemēram,

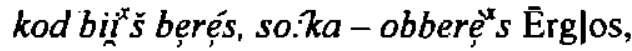

mess labi abbèrèjà̀m, ar ceremoniju vis Kārzdabā,

apbierej pa gùdam Karvā.

Pamatā tam ir vārds bēres, kuru J.Endzelīns hipotētiski saista ar darbỉbas vārdu bērt un aizguvumu no viduslejasvācu böre '(liḳu) nestuves' (ME I 290). K.Karulis savukārt konstatējis, ka gan latviešu bērt, gan viduslejasvācu böre nozīme ir attīstījusies no vienas saknes *bher ar nozīmi 'nest' - tātad nozīmes varētu būt attīstījušās paralēli (LEV I 121). Sporādiski registrēti arī varianti apbẹruot Trapenē un apbȩ̄uot Kursīšos, Lutriṇos un Virgā.

Atsevišḳās Vidzemes sēliskajās izloksnēs fiksēts vārds bērēt (beireit) ar nozīmi 'ska|ji raudāt' Domājams, ka tā varētu būt sekundāra nozīme, kas attīstījusies no vārda apbērēt 'apglabāt, apbedīt', tomēr šis jautājums ir diskutējams un prasa plašākus pētījumus.

Lejaskurzemē (Dunikā un Rucavā) fiksēts vārds pakavāt, kas aizgūts no liet. pakorvóti, kur tas savukārt pārņemts no polu pochowac' 'apbedī'

ME III 476 ar nozīmi 'apglabāt mirušo' no Ances un Ventas dots vārds ramīt (sal. liet. raminti 'ruhig machen'). Tas 
registrēts arī 17. gadsimta rakstu avotos ar norādi par izplatību Kurzemē. ${ }^{2}$ Mūsdienu izlokšnu vākumos tas nav reg̣istrēts.

Ar apbedī̌sanu saistīti arī dažādi ticējumi, piemēram, ir ticējums, ka mirušo nedrīkst glabāt pēcpusdienā ( $P \bar{e} c$ pusdienas velu bērni velu vārtus aizvēruši, LTT III 1535).

\section{Saīsinājumi}

$\mathrm{EH}$ - Endzelīns J., Hauzenberga E. Papildinājumi un labojumi K.Mīlenbaha Latviešu valodas vārdnīcai. - R., 1934-1946. - 1.-2. sēj.

LEV Karulis $K$. Latviešu etimoloǵijas vārdnīca divos sējumos. - R., 1992.

LLVV Latviešu literārās valodas vārdnīca. R., 1972-1996, 1.-8. sēj.

LTT - Latviešu tautas ticējumi / Sav. un sakārt. P.Šmits. - R., 1940. - 3.sēj.

ME Milenbahs $K$. Latviešu valodas värdnīca / Red., papild., turp. J.Endzelīns. R., 19231932. - 1.-4. sēj.

ide. $\quad-$ indoeiropiešu

jaun. p. - jaunākā paaudze

liet. $\quad-$ lietuviešu

\section{MEANINGS OF THE VERBS RAKT 'TO DIG' AND $A P B E D I T$ 'TO BURY' IN LATVIAN DIALECTS Summary}

The Standard Latvian word rakt 'to dig' is spread almost throughout Latvia. The second meaning 'to bury' also occurs in

2 Trevor G. Fennel. Fürecker's dictionary: the first manuscript. Riga, 1997, p. 195. 
all dialects, less common in Latgale and Augšzeme. The variations nuorakt, rakt nuost, rakt nuosti are recorded in some subdialects of northern Vidzeme.

Some other verbs with the meaning 'to dig' are known in dialects:

best - forms a compact area in north-eastern Vidzeme, northern and eastern Latgale. With the shade of meaning 'to dig a hole for a grave' the verb best is recorded in some subdialects of Vidzeme. In nothern Vidzeme the word best is used with the meaning 'to bury';

kast - occurs in southern Latgale, Augšzeme and in south-western Kurzeme;

raust - is known in the meaning 'to dig' and 'to bury' in subdialects of eastern Latgale. With the shade of meaning 'to fill up a hole for a grave' raust is also used in the subdialects of central Latgale.

The Standard Latvian word apbednt 'to bury' does not form a united area, it occurs most frequently in central Vidzeme. The variation apbedtt is recorded in some subdialcts throughout Latvia.

The most widespread verb is (ap-, pa-)glabät 'to bury', also being a word of Standard Latvian.

In some subdialects of eastern Vidzeme the word (ap)bēeret 'to bury' is recorded. The borrowing pakavāt (Lith. pakavóti < Pol. pochować) occurs in some subdialects of southwestern Kurzeme. 


\section{Inese ẼDELMANE \\ ASOCIĀCIJAS LATVIEŠU VALODAS AUGU NOSAUKUMOS}

Lĩdzās psihologu pētījumiem par asociāciju veidošanos cilvēka apzinnā arī valodnieki ir akcentējuši domu, ka visas valodas vienỉbas ir pak]autas arī tādăm likumsakarībām kā stabilām asociācijām, kas saistītas ar priekšstatiem un parādỉbām, ko vārds apzīmē.

Tātad, par asociācijām uzlūko to priekšstatu sakarības, kurām pastāvot, viens priekšmets (uz līdzības, radniecības vai pretstata pamata) izraisa apziṇā nojēgumu par citu priekšmetu.

Lai noskaidrotu jēdzienu formēšanos cilvēka apziṇā, ārsti un psihologi ir izdarījuši virkni eksperimentu, kuros izmantota dažāa aparatūra un dažādas metodes bieži matemātiskas metodes.'

Pētnieki, tostarp arī valodnieki, ir centušies noskaidrot to stimulu, kas rada attiecīgās asociācijas un liek izvēlēties to vārdu, kurā nosauc jauno reāliju.

Piemēram, augam baltā üdensroze (Nymphaea alba) dažās Kurzemes, Vidzemes un Zieme|latgales izloksnēs ir nosaukumi gaigalas vai gaigales, jo uzplaukušu ūdensrožu baltie ziedi uz rāma ūdens līmeṇa runātājiem ir asociējušies ar šiem üdensputniem. Vārds gaigala, ko te lieto pārnesti, ir nirpüles ${ }^{2}$

${ }^{1}$ Par to skat. Щур Г.С. О типах лексических ассоциаций в языке. Grām: Семантическая структура слова (Психолингвистические исследования). Москва, 1971, стр.140-150. Леонтьев А.А. Психологическая структура эначения. Grām.: Семантическая структура слова (Психолингвистические исследования). Москва. 1971, стр. 7-18. Шур Г.С. Об ассоциативных группах в яэыке.

Grām.: Материалы второго симпозиума по психолингвистике. Moсква 1968.; Reinerss L. Stilkunst. München, 1943, S. 65.-102.

2 Baumanis J, Blams P. Latvijas putni. R., 1969, 26.-27. Ipp. 
(Bucephala dangula) nosaukums. Šĩ putna riesta tērps ir uzkrītoši melni balts.

V.Ancītis norāda, ka folklorā dažkārt par gaigalām sauktas noslïkušo dvēseles. ${ }^{3}$

Kā vienā, tā otrā gadījumā šis t.s. stimuls jeb asociāciju izraisītājs ir auga baltais zieds.

Par līdzīgu asociāciju izraisītāju raksta arī prof. J.Endzelīns, atbildot filologam J.Zēveram, kurš savā laikā kritizēja profesora izveidotās vārdu etimologijas K.Mīlenbaha vārdnīcas piebildēm. Runa ir par vārda paslovvas etimologiju. J.Endzelĩns raksta: "Ka paslavas isti ir augšgalā platas bikses, bet ne zeḳes, sevišḳi skaidri rāda stāda vārds gaila paslavas (arī gaila bikses - Primula veris); šā stāda stiebrs, ko apakšdalā sedz lapas, var atgādināt gaịa vidusda|ā spalvoto stilbu, kas līdzinās tādām paslavām ("Pluderhosen"). ${ }^{4}$

Lūk tā veidojas stabilas asociācijas, kas saistîtas ar priekšstatiem par parādību, ko vārds apzīmē. Līdz ar to tās pilnībā nav nevalodnieciskas asociācijas. Tās k|ūst par valodas faktu un veido plašus tematiskus laukus, ieraujot savā darbïbas sfērā veselu virkni vārdu un līdz ar to dodot potenciālu iespēju pārnestam izlietojumam. ${ }^{5}$

Kā norāda valodnieks D.Šmejevs, ${ }^{5}$ valoda veido it kā ipatnēju filtru, caur kuru iet visi asociatīvie lietojumi. Protams, ne jau tie visi nostiprinās valodā, klūstot par pārnestiem lietojumiem.

Tūlin gan jāpiezīmē, ka starp augu nosaukumiem tieši šãdu pārnestu lietojumu ir daudz.

D.Šme|evs arī pasvītro, ka šie pārnestie lietojumi, apvienojot veselas tematiskas grupas, veido so grupu semantisko struktūru, pārstāvot tās iekšęjās attieksmes, ko sākotnēji sauc par

Anctis $\boldsymbol{V}$ Latvju dainu izlase. R., 1984, 217. Ipp.

4 Endzelins J. Darbu izlase III, 1. R., 1979. 446. Ipp.

Шмелев Д.Н. Проблемы семантического анализа лексики. Москва, 1973. 
derivācijas attieksmēm vārda plašākajā nozīmēe. Derivācija te ir interpretēta kā motivācija, jo, piemēram, atvasināti vārdi ir motivējami no pamatnozīmes: bērzs $\rightarrow$ pabērzs; egle $\rightarrow$ paegle; virza $\rightarrow$ pavirza ar nozīmi 'neīstais bērzs; neīstā egle; neīstāa virza'

Kā jau vairākkārt norādīts, ${ }^{6}$ izdarot latviešu valodas augu nosaukumu lingvistisko analīzi, ir konstatēts, ka latviešu valodā augu nosaukumiem būtiska ir nosaukumā ietvertā 1) pašam augam raksturīgā īpašỉba, 2) asociatīva līdzìba ar kādu citu reāliju un 3) augu izlietojuma funkcija.

Visvairāk augu nosaukumu latviešiem ir tādi, kas radušies uz dažādu asociāciju pamata. Visbiežāk tās ir izskata vai izlietojuma funkcijas asociācijas, taču sastopamas arī ožas, garšas, taustes, pat skap̣u uztvēruma asociācijas.

Augu nosaukumos asociatīvā priekšstata izraisītājs parasti ir pats augs vai kādas tā dalas, loti bieži zieda forma, krāsa, smarža u. tml.

Piemēram, Eiropas saulpurenes (Trollius europaeus) zieda forma un dzeltenā krāsa mudinājusi saistīt auga nosaukumus ar putnu mazula cāja vārdu vairākās Zieme|vidzemes izloksnēs. Tā saulpurene ir cāla galva Liepnā, cālgalva Lugažos, cālgalvina Ērgemē, cālu galvas Gulbenē, Mārkalnē, Pededzēe, Trikātā.

Griezuma vai lauzuma vietā izdalījusies balta vai dzeltena piensula vedinājusi nosaukt grupu dažădu augu par pienenēm vai strutenēm. (Piemēram, pienenes ir ärstniecübas pienenes (Taraxacum officinale), dievkrēslini (Euphorbia), vēlpienes (Leontodon), mïkstpienes (Sonchus) un kāda pienainu gints sēne Lactarins, bet augu Chelidonium majus gandrīz visā Latvijā dēvē par strutenēm.)

${ }^{6}$ Edelmane I. Latviesu valodas augu nosaukumu leksiskā motivācija.

Grām.: Linguistica Lettica. R., 1997, 1, 55. Ipp.; Édelmane I. Nezā|u nosaukumi latviešu valodas izloksnēs. - Latvijas Zinātṇu Akadēmijas Vēstis. A. 1993., Nr. 8., 19. Ipp. 
Par asociāciju izraisītāju var klūt arī auga smarža vai smaka. Arrstniecības melisi (Melissa officinalis) bieži dēvē par citronmētru vai citronmelisu, ${ }^{7}$ jo auga lakstu smarža atgādina citrona smaržu. Turpretī lauku blaktenes (Ononis arvensis) ziedu un lakstu asā smaka atgādina saspiestas blaktis. (Tādè] augam attiecīgi nosaukumi - blaktene Bauskā, Lìksnā, Misā, Vecsaulē, vai smirda Dobelē.)

Asociāciju var izraisīt garša, piem., meža zakskābenes (Oxalis acetosella) lakstiem ir skābenēm līdzīga garša, tādē| ir arī attiecīgi nosaukumi: zaķu skābenes Aizputē, Bauskāā, Irlavā, Kuldīgā, zaķu skābes Aizputē, zaksskābenes Vandzenē, skäbais $\bar{a}$ bolings $\bar{s}^{\mathbf{B}}$ u. c.

Nereti arī taustes sajūtas ir asociāciju izraisītāji. Piemēram, nātres sauc arī par dzeltenē ${ }^{9}$ tāpēc, ka tās dze], kad pieskaras.

Ievērojamā Vidzemes un Latgales izlokšnu da|ā, vietumis arī Kurzemē, piem., Ancē, mällēpes (Tussilago farfara) dēvē gan par pamātēm, gan pamāšu lapām, jo, kā raksta J.Ilsters, lapas "mîkstā apakšpuse, slēpusies pie zemes un neredzama kā (mirusi) īstā māte, kailā, cietā virspuse, kas vien redzama, ir kāa pamāte" 10

Asociāciju var izraisīt arī skạ̣a, kas pirmajā mirklī škiet pat neiespējami.

Nopakšķ vai nopaukšks, kad no kausiṇa norauj spradzenu (Fragaria viridis) ogu. Tādē| arī izlokšṇu nosaukumi ir spradzene vai sprädzene Irlavā un Zantē, arī brakšksenes. ${ }^{\prime \prime}$

${ }^{7}$ Karkligua L. Mūsu garł̌augi. Latvju Grāmata, R., 1942, 22. lpp.

Švikule D. Veselīgākās zāju tējas. R, 1980, 55. lpp.

${ }^{8}$ Petersone A. Savvalas ārstniec ỉbas augi. R., 1963, 342. Ipp.

${ }^{9}$ Pêtersone A. Savvalas ārstniecības augi. R, 1963, 194. lpp.

10 Latviešu botāniskie nosaukumi, sastādīti no J.Ilstera. Otrais salasījums. - Grām.: Rīgas Latviešu biedrïbas Zinību komisijas 3. rakstu krāj. R., 1885, 73. Ipp.

Mitenbahs K. Latviešu valodas vārdnīca. Red,, papild., turpin. J.Endzelms. R., 1923, 1.sēj., 323. lpp. 
Idũ par čakstenēm vai čaukstenēm dēvē salmenes vai salmu pukes (Helichrysum), kuru sausie ziedi vējā vai arī tiem pieskaroties patiesi čakst vai čaukst.

Nereti asociāciju izraisa auga uzziedēšanas vai intensīvās augšanas laiks.

Jau pieminētā māllēpe (Tussilago farfara) uzzied agri pavasarî, lapas turpretī izplaukst krietni vien vēlāk, kad augs jau sen noziedējis. Tās ir pavasara beigas, kad salapojuši visi koki, kad atlidojuši pēdējie gājputni vālodzes, tāpēc, piemēram, Liezerē, Piebalgā u. c. Vidzemē augu dēvē par vâlodźu lapām.

Kā dekoratīvus augus pie mums plaši kultivē vairākas asteru (Aster) sugas ar daudzām šķirnēm.

Tie ir daudzgadīgi augi, kas uzzied vēlu rudenī, tautā tos bieži dēvē par mikelîtèm, miḳelenēm, miǩnelnīcām u. tml. Kā raksta J.Ilsters, tās ir arī "precinieku pukes jeb precenes Koknesē - rudenī, preciniekus gaidot, ar viñām apvij logus un durvis, rudenspukses Dobelē, miķelnīcas Vestienā zied ruden̄̄ uz Miķejiem, kārklenes - Stukmaṇos (Plavin̄ās), jo lapas kā pie kārkliem."12

Ārsti un psihologi, pētot asociāciju veidošanos cilvēka apziṇā, pievērš uzmanību arī tādiem faktoriem kā cilvēka vecums, dzimums, izglītība, profesija, arī geogrāfiskā vieta, kur cilvēks dzīvo.

Iespējams, ka tieši šo iemeslu dēl augi, kas atšķiras no citiem (vienas gints dažādu sugu, vai arī izskatā līdzīgiem dažādu ginšu augiem) ar to, ka tie ir lielāki, garāki, leknāki u. tml. par pārējiem, latviešu valodā ir saistīti ar leksēmu zirgs. Piemēram, ir zirgskābenes (Rumex confertus) vai zirgkumelītes (Anthemis arvensis) vairākās Vidzemes un Kurzemes izloksnēs. Šajos gadījumos latviešiem, kas ir zemnieku tauta, asociācijas

12 Latviešu botāniskie nosaukumi, sastādīti no J.Ilstera. Otrais salasījums. - Grām.: Rīgas Latviešu biedrības Zinību komisijas 3. rakstu krāj. R., 1885, 69. Ipp. 
radušās ar lauku kopējam pašu tuvāko un vislielāko dzīvnieku zirgu (ziloṇu, žirafu vai citu milžu šajā klimatiskajā josłā nav).

Kandavā šaurlapu celteku (Plantago lanceolata) dažas gimenes dēvē par $u t i$, jo š̄i auga loti sīkās sēklas grūti iztîrāmas no äbolina (Trifolium) sēklām.

Loti bieži par asociāciju izraisītāju ir kalpojusi auga izlietojuma funkcija.

Vairākus augus tautas medicīnā lieto pret bezmiegu. Lietojuma funkcija runātājiem ir asociējusies ar nakti un miegu un bijusi par pamatu attiecīgas leksēmas izraudzīšanai augu nosaukumiem. Tā Latgales izloksnēm raksturīgie zilās rudzupukes (Centaurea cyanus) nosaukumi naktene, naksnene, naktenīte, naktenica, naktinica u. c. tiem līdzīgie, šķiet, saistāmi ar apvidum īpatnēju ticējumu: sakaltētus rudzupuķu ziedus te dedzinājuši un ar to dūmiem apkūpinājuši nemierīgus bērnus, lai tie naktīs labāk gulētu. ${ }^{13}$

Ar miegu un nakti saistīti nosaukumi reǵgistrēti arī indīgajam augam melnā naktene (Solanum nigrum), piemēram, miega zāle Alsungā, Irlavā, Jūrkalnē, Padurē, Piltenē, Ventā, Zūrās, naktenes Irlavā, Plaviṇās, Skaistkalnē, naktenicas Plaviṇās. Kā 1885. gadā rakstīja botāniḳis J.Hsters "Stukmaṇos (t.i., Plaviṇās) šo augu ṇem pie nemierīgu bērnu mazgāšanas, lai tie nakti labāk gul (kad negulēs, stādam diezgan ğifts apreibināšanai!)."14

Kā zināms, augu dzīvē svarīga loma ir to apputeksnētājiem kukaiņiem. Pirmā vieta te pieder bitēm.

Ar vărdu medus vai bite veidoti vairāku nektāraugu nosaukumi izloksnē, jo runātājiem šie augi it kā asociējas ar bišu darbību. Tāpēc madaras (Galium) ir medenes Piltenēe, medulāji

13 Edelmane I. Augu Centaurea cyanus un Leucanthemum vulgare nosaukumu semantika un izplatība latviešu valodā. Grām.: Dialektālās leksikas jautājumi. R., 1. sēj., 1986, 206. lpp.

14 Latviešu botāniskie nosaukumi, sastādīti no J.Ilstera. Otrais salasījums. - Grām.: Rīgas Latviešu biedrības Zinību komisijas 3. rakstu krāj. R., 1885. 
Alsungāa, Jūrkalnē, medulenes Alsungā, Ancēe, Jūrkalnē, med(u)spukse(s) Dundagā, Padurēe, Zūrās.

Ar biškopỉbu saistīti nosaukumi ir arī augiem baltais amolinš (Melilotus alba) vai ärstniecības amolinšs (Melilotus officinalis), ko dēvē par bišu amolinu Ābelos, Bērzpilī un bišu äbolu Nautrēnos, bet nektāraugus ārstniecības vēršmēle (Anchusa officinalis) sauc par bišu nātrēm Alūksnē un sirds māteres (Leonorus cardiaca) par bišu mētru Vecumniekos.

Arī melisas (Melissa) plaši dēvē par bišu mētru ${ }^{15}$ un bišu $z a \bar{a} i^{16}$, lî̉zīgi arī lietuviešu izloksnēs bičiu žolè un bitzolès ${ }^{17}$ Nosaukums acīm redzot veidojies no tā, ka bitēm tỉkamās smaržas dēl šo augu nereti mēdz ielikt bišu stropos saimes pieradināšanai vai pievilināšanai.

Veidojot augu nosaukumus, senais latvietis, labs dabas pazinējs un rūpīgs vērotājs, salīdzināja citas reālijas ar augiem un atrada potenciālu iespēju attiecīgo nosaukumu pārnestam izlietojumam.

$\mathrm{Uz}$ asociativvas līdzibas pamata veidotajos nosaukumos saskatāmi dzejai raksturīgi tropu veidi.

K.Kārkliṇš ${ }^{18}$ apcerējumā "Latviskie puķu nosaukumi" skaidro, ka tautas radošais gars parādās arī atsevišķu vārdu veidošanā un vārds kā dzejas darbs it bieži ir sastopams latviskajos puķu nosaukumos.

Piemēram, auga, kuru dēvē par amarantu (Amarantus), zieds atgādina asti. Izloksnēs to dēvē par kaķasti, pelasti, lapsas asti. Auga nosaukuma pamatā ir salīdzinājums, bet salīdzinājums ir metaforas veids, tātad nosaukuma pamatā ir metafora.

${ }^{15}$ AŠmanis K. Latvijas flora. R., 1923, 208. Ipp.

${ }^{16}$ AŠmanis K. Latvijas flora. R., 1923, 208. Ipp.

${ }^{17}$ Lietuviškas botanikos žodynas I d. Redagavo J.Dagys. Kaunas, 1938, 218. lpp.

${ }^{18}$ Karklings K. Latviskie puķu nosaukumi. - Krāj.: Celi. R., 1933, 3. laid., 67,-71.lpp. 
Latviešiem šādu nosaukumu ir daudz - visas kaķu un zaķu pēdinas, vistu un vārnu käjas, kumelu pēdas, uzpirkstītes u. c. ir metaforas.

Puķu vārdos sastopama arī metonīmija, piem. nosaukums purene (Caltha palustris) cēlies no auga augšanas vietas, kas ir purvs, mitra plava, ūdensbaseina mala. Metonīmija ir arī tādos augu nosaukumos kā palagzdes, elksnenes, kūdrājas, grồvenes, elkšņu vijoles u. c.

Tāpat augu nosaukumos spilgti redzama arī sinekdoha. Veselas virknes dažādu pazīmju vietā, kuras piemīt augam, augs nodēvēts tikai pēc kādas vienas tam piemītošās pazìmes. Arī tie nosaukumi, kas radušies uz metaforas un metonīmijas pamata, visbiežāk slēpj sevī arī sinekdohu. Piemēram, nosaukumā kumejpēda (Asarum europaeum) no veselas virknes augam raksturīgu īpašỉbu tā nosaukumā atspogulota tikai viena, šĩ auga lapas izskata līdzîba ar smiltīs vai sniegā iemītu (vēl neapkalta) kume|a pēdu.

Un, ja jau auga nosaukumu pamatā ir tropu veidi, tad tie tiešām veidojušies kā tautas dzejas darbi. Ar laiku vārds zaudē savu dzejisko dabu, jo izgaist viens no vārda elementiem sākotnējais priekšstats, kas bija pamatā nosaukuma izveidei. Šìs parādības cēlonis meklējams vārda nozīmes paplašināšanās procesā. Piem., vārdā zāle jau sen zudis krāsas priekšstats za|š, kas ir nosaukuma pamată ${ }^{-1}$, tādē| tagad sakām arī zala zâle (lai izteiktu šo nojēgumu, ka zāle nav nodzeltējusi; senāk, šḳiet, iztika tikai ar vienu vārdu - zāle).

\section{ASSOCIATIONS IN PLANT NAMES OF LATVIAN LANGUAGE Summary}

Most of plant names for Latvians are such as created on the base of different associations. Frequently those are

${ }^{19}$ Mtlenbahs K. Latviešu valodas vārdnīca. Red., papild., turpin. J.Endzeltns. R., 1929-1932, 4. sēj., 698. Ipp. 
associations of functions, of appearance and use, however smell, taste, touch and sounds receive associations.

When investigating new forming concepts in man's consciousnes, psyhologists try to clear up so to say stimulus - an agent which creates associations, but linguists - a word which names the new reality.

Often the agent of associations is plant itself or some part of it: often flower form (for example: Cypripedium calceolus - dzegužkurpïtes - lady's slipper), colour (Rubus fruticosus - melnā avene - blacberry), smell, growing place of plant, its intensive growing and bloom time and so on.

To compare others realities with plants, speakers find can use names figuratively. 


\section{Māra ŠNĒ}

\section{PAR VISTAS NOSAUKUMIEM LATVIEŠU VALODAS IZLOKŠṆU LEKSIKĀ}

Latvieša kā zemnieka dzīvē allaž liela vieta bijusi mājputniem, jo sevišķi vistai latvietim tik tuvam un arī nepieciešamam putnam. Par to vēstī arĩ šī tautasdziesma:

Kas kaitēja man dzīivot

Pie vistiņas, baltspārnītes;

Vistiṇ' olu dējējiṇa,

Es oliņu èdējiṇa.

Latviešu izlokšņu leksika sniedz bagātu un daudzpusīgu materiālu gan savva|as, gan arī mājputnu apzīmēšanai, taču visvairāk nosaukumu, šķiet, ir tieši vistas raksturošanai. Šajā rakstā aplūkota šī mājputna nosaukumu daudzveidība dažādos Latvijas novados, arī vārdnīcās, pievēršoties galvenokārt nosaukumu semantiskajam un areālajam aspektam.

Literārajā valodā šĩ putna nosaukumi ir - vista, perētāja vista (LLVV 8, 544) un klukste 'vista, kas perē vai vadā cā|us' (LLVV 4, 271), kas uzlūkojams par sinonīmu nosaukumam perētāja vista. Bez tam sarunvalodā vēl sastopams nosaukums tiba - 'vista' ( $\operatorname{LLVV~} 72,518)$.

Visvairāk izlokšņu leksikā ir tādi vistas nosaukumi, kas ietver tikai emocionālu attieksmi pret apzimēto putnu, neraksturojot to ne pēc kādām konkrētām pazīmēm. Visbiežāk šiem nosaukumiem ir mīlinājuma nokrāsa. Daudzi apzīmējumi atrodami arī nosaukumam perētäja vista, resp., klukste.

Pārējie, ne tik bieži sastopamie nosaukumi raksturo vistu pèc:

1) ķermeṇa izmēriem;

2) ārējā izskata, resp., ārējās līdzības ar kādu citu putnu;

3) ķermeña apspalvojuma krāsas;

4) vecuma.

Ši mājputna literārais nosaukums vista tiek lietots pârsvarā visā Latvijas teritorijā. Tas registrēts arī K.Mīlenbaha 
Latviešu valodas vārdnīcā (ME IV 626) un citās vārdnīcās (EH II 790; Dr 346; St 364; U 343; V 220).

Arī nosaukuma vista deminutīvs vistinga, kam piemīt mīlinājuma nokrāsa, sastopams gandrīz visos Latvijas novados, mazāk to lieto Austrumlatvijā, kur galvenais deminutīvu darināšanas formants ir piedēklis -en-. ' Cirgalos un Vecatē lieto ar piedēkli -īn- darinātu deminutīvu vistīna. Lielā Vidzemes izlokšnu da|ā deminutīvu darināšanā lieto piedēkli $-\bar{i} n-^{2}$

Bez šiem nosaukumiem, kam ir mīlinājuma nokrāsa, atsevišķos Latvijas novados izplatīti arī nosaukumi, kas izsaka zināmu nievājumu - vistele (Dienvidrietumlatgalē, arī Sinolē, Sēpelē, Vecatē), vistene (Sinolē), vištele (Zemgalē; U 343), vištelīte (Zemgalē). Nosaukumos vištele, vištelīte varbūt saglabājusies baltu -š- skaṇa (sal. ar lietuviešu višta).

Îpatnējs ir Dienvidaustrumvidzemē lietotais deminutīvs vistuška. Tas, šķiet, ir darināts pēc analog̉ijas ar krievu valodas deminutīviem.

Vistas nosaukumi tiba, tita, tipa, ciba, arī šo nosaukumu deminutīvi sastopami galvenokārt bērnu runā un uzlūkojami par mīlinājuma vārdiem. Nosaukumu tiba lieto Ziemelvidzemē mẹllā tiba dēj katru dienu (Sinolē). Arī K.Mīlenbaha Latviešu valodas vārdnīcā atrodams šis nosaukums (ME IV 179). Daudzveidīgi ir tā deminutīvi tibinga (Koknesē, Vestienā, Krapē, Saikavā - ME IV 179), tibin̄š (Svētciemā), tibüte (Sinolē), tibìtis (Rūjienā), tibina (Vecatē), tibucīte (Vestienā - ME IV 179), tibuka (Sinolē), tibulīte (Vecatē; ME IV 179). Kā redzams, arī šī nosaukuma deminutīvi ir izplatīti Zieme|vidzemē, nedaudz arī Dienvidvidzemē (ap Vestienu).

Savukārt nosaukums tita un tā deminutīvs titinga sastopams galvenokārt Zieme|latgalēe - vecmāmiņ, kādēl pẹ̦ lẹkā tita klibuo, kas vinai kājingai vainas? (Bejā). Nosaukums tita

\footnotetext{
${ }^{1}$ Rudzīte M. Latviešu dialektolog̣ija. - R., 1964., 317.lpp.

${ }^{2}$ Rudzīte M. Latviešu dialektolog̣ija. - R., 1964., 105.lpp.
} 
nedaudz lietots arī Zieme|vidzemēe - Sinolē, Vecatē un Valmierā.

Nosaukums tipa un tā deminutīvs tipinga registrēts tikai Dignājas izloksnē.

Bet nosaukumu ciba un tā deminutīvus lieto Vidzemē un nedaudz arī Kurzemē (Kuldīgā, Kursīšos, Strazdē), Latgalē (Dignājā) un Zemgalē (Stelpē - ME I 378). Nosaukums ciba reǵistrēts arī K.Ulmaṇa Latviešu-vācu vārdnīcā (U 348). Šĩ nosaukuma deminutīvi ir cibina (Stelpē - ME I 378; Sinolē, Strazdē), cibinšs (Svētciemā), cibīte (Sinolē), cibule (Sinolē), cibulīte (Dignājā), cibulis (Raunā, Grobiṇā - ME I 379).

K.Mīlenbaha Latviešu valodas vārdnīcā registrēts nosaukuma ciba variants cibe (Vainodē - ME I 378) un tā deminutīvs cibīte (ME I 378), kā arī nosaukumi čibīte un čibulīte (ME I 412). Sinolē un Zasā (ME III 407) lietots vistas mīlinājuma vārdinš pulina. Savukārt Svētciemā izplatīts vistas nosaukums gāginsš, kuru gan parasti attiecinām uz zosīm. Šis nosaukums darināts no substantīva gāga, kura pamatā ir skaṇu verbs gāgināt - 'radīt raksturīgas stieptas balss skaṇas (parasti par zosīm)' (LLVV 3, 25; arī ME I 616).

Savukārt Priekulē ir registrēts vārdu savienojums vistinga gägina - vistina gāgina, palīdzi dziedāt... (Ld l 399). Šḳiet, ka abos gadījumos gāginšs, tăpat kā ciba, tipa u.tml. uzlūkojams tikai par vistas mīlinājuma vārdinu. Tas neraksturo apzīmējamo putnu pēc tā balss skañām. Par mīlinājuma vārdu uzskatāms arī Rēzeknē registrētais vistas nosaukums visteña māseña (PŠ I 322). Kā jau iepriekš minēts, Austrumlatvijā piedēklis -en- ir galvenais deminutīvu darināšanas formants. ${ }^{3}$

Dažāà ir nosaukumi perētājas vistas, resp., klukstes raksturošanai. Literārajā valodā izplatītais nosaukums klukste tiek lietots Vidzemē (ap Lubeju - ME II 234; Vaimierā), kā arī Dignājāa. Reg̉istrētas arī šì nosaukuma paplašinātas formas

${ }^{3}$ Rudzīte M. Latviešu dialektologija. - R., 1964., 317.lpp. 
klukstene (EH I 622; Laucienā), klukstere (EH I 622), klukstệtäja (Alūksnē - ME Il 234).

Džūkstē un arī Lubejas apkaimē līdzās nosaukumam klukste lieto nosaukumu klukškse. K.Mĩlenbaha Latviešu valodas vārdnīcā regíistrēts vistas nosaukums ar reducētu $-k$ - skaṇu klušķe (ME II 238). Smiltenē perētājas vistas raksturošanai lieto nosaukumu kludze (ME II 233), kas radies no verba kludzēt 'kladzināt' (ME Il 233). Bet Vecatē registrēts perētājas vistas nosaukums klacka, kura pamatā varētu būt verbs klacināt 'kladzināt' (EH I 607).

Austrumlatvijā un nedaudz arī Zemgalē un Kurzemē izplatīti perētājas vistas nosaukumi perekle (Varak|ānos - ME III 201), perēkle (Bauskā - ME III 201), perikle (Aknīstē), perele (Rankā - EH II 224), perene (Sinolè; Lielsesavā - ME III 201), pericka (Sinolē, arī Konv 16, 31570), perine (Dignājā), perenīca (Sinolē; Vecpiebalgā - EH II 224), pērklene (Konv 16, 31636). Neierastāks no šiem nosaukumiem škiet nosaukums perenica, bet Austrumlatvijā piedēklis -nicc- ir tipisks sievišķo ìpatṇu nosaukumu darināšanas formants. ${ }^{4}$ J̄patnējs ir arī nosaukums pērklene, kura pamatā ir substantīvs pērklis - 'perēklis' (ME III 208). Savukārt Nīcā registrēti perētājas vistas nosaukumi peringa un perindze, kuri ir substantivizējušies adjektīvi - aka viena perindze - grib perēt, a tām perindzèm nevar gläbties. Alūksnē sastopama šo nosaukumu saīsinātā forma pere (ME III 201).

Džūkstēe izplatīts pavisam īpatnējs perētājas vistas nosaukums cāle, ko loti grūti saistīt ar vistu - abjas divi cāles dēja bez jëgas (EH I 262).

K.Mīlenbaha Latviešu valodas vārdnīcā un arĩ citās vārdnīcās reg̣istrēti visdažādākie divvārdu nosaukumi perētājas vistas raksturošanai - perelu vista (Ungurmuižā - EH II 224), perēja vista (Krustpilī, Meirānos - ME III 201; Biržos - EH II 224; U 199; Konv 16, 31572), perīkle vista (Neretā, Aknīstē -

${ }^{4}$ Rudzīte M. Latviešu dialektoloğija. - R., 1964., 320.lpp. 
EH II 224), perine vista (Biržos, Gramzdā - EH II 224), periga vista (Saldū, Varak’ānos - EH II 224; Konv 16, 31599), perīte vista (Gramzdā - EH II 224), perūkle vista (Mežamuižā - EH II 225). Bet literārajā valodā pašreiz lietojamo nosaukumu perētāja vista tur neatrodam. Toties šis nosaukums pirms diviem gadsimtiem ir uzrādīts G.F.Stendera Latviešu leksikonā (St 193). Šajā vārdnīcā ir minēts arī divvārdu nosaukums, resp.,vārdkopnosaukums dējiga vista - 'laba dējējvista' (St 39).

Izlokšnu leksikā mazāk atrodarni vistas nosaukumi, kas putnu raksturo pēc tā ķermeņa izmēriem, àrējā izskata, resp., ārējās līdzỉbas ar kădu citu putnu, kā arī ḳermeṇa apspalvojuma krāsas vai vecuma.

Ziemelkurzemē (ap Ventspili, arī Nogali) pēc ḳermeṇa izmēriem seviški maza vistina tiek saukta par krüpinu (EH I 662). Ši nosaukuma pamatā varētu būt apvidvārds krupis 'rūķītis' (ME II 287). Nosaukums krüpinšs radies nozìmes pãrnesuma rezultātā no mazas cilvēkveida mitologiskas būtnes uz mazu vistu.

N̦emot vērā dažreiz pamanāmo vistas ārējo līdzību ar pūci, izloksnēs, galvenokārt Zemgalē, darināti dažădi nosaukumi vistas raksturošanai. Šo nosaukumu pamatā ir vistas (galvas, kāju, knābja vai deguna) apspalvojuma līdzība ar pūces apspalvojumu.

Jau G.F.Stendera Latviešu leksikonā atrodams nosaukums pūcīte - 'vista, kas kā pūce noaugusi' (St 210). Ar līdzīgu nozīmi 'vista pūkainu galvu' nosaukums pūcīte lietots Zemgalè - bij tādas bārzdinas viñām, tās par pūcìtēm sauca, $k a$ tâdas vistinas bij, ta tādas pūcîtes (Têrvetē). Vietumis Zemgalē (Sniķerē, Ukros) lieto arī nosaukumu pūce 'vista pūkainu galvu' Vecaucē ar šo pašu nozìmi izplatīts nosaukums püčele, bet Vadakstē pükaine. Mērsragā līdzās tiek lietoti divi nosaukumi pücgalviňš un pücitis 'vista ar spalvainām kājām' Ap Dobeli izplatīts nosaukuma pükaine deminutīvs pükainite, karn blakus lieto nosaukumu kepainīte. Abu minēto nosaukumu nozīme ir 'vista ar spalvainām kājām'. Savukārt ap 
Zajeniekiem lieto nosaukumus pūknāse (ME III 446) un pūknāsis (EH II 341) - 'vista ar spalvainu knābi vai degunu' baltraibā pūknäse gan iesākumā neẹsuot gribējusi tupēt uz uolām (Svētē).

Dažās Latvijas izloksnēs regiistrêti vistas nosaukumi, kas putnu raksturo pēc tā ḳermeña apspalvojuma krāsas. Vista ar sirmu vai raibu kaklu Dignājā tiek saukta par sāmali. Šis nosaukums atvasināts no apvidvārda sāms - 'raibs' (ME III 803). Sinolē izplatīti vistas nosaukumi raibīte, cẹkulīte un pākste, kuru nozīme ir 'vista, kam kakls un aste tumšāki' Savukārt J.Langija Latviski-vāciskā vārdnīcā reǵistrēti vistas vārdkopnosaukumi raiba vista ( $\mathrm{Lg} 349)$ un lāseina vista $(\mathrm{Lg} \mathrm{349)}$.

Izlokšņu leksikā atrodami atsevišķi nosaukumi, kas raksturo vistu pēc vecuma. Vecas vistas apzīmēšanai Rundālē un Susējā lieto nosaukumu übeliene, kas, liekas, darināts no apvidvārda übelis 'vecs zirgs' (ME IV 403). Nosaukums übeliene radies nozīmes pāmesuma rezultātā no veca zirga uz vecu vistu. Vecpiebalgā veca vista tiek saukta par klucku (EH I 621), bet Sinolē par klučku. Savukārt Vecatē vecu vistu raksturošanai lieto nosaukumus caba un capa. Nosaukums $c a b a$ vecu vistu apzīmēšanai tiek izmantots arī Dignājā. Turpretī vecuma ziṇā mazāku vistu apzīmēšanai Vecatē lieto šo nosaukumu deminutīvus cabina un capina. Vistas, kam ir mazulis vai mazuli, t.i., cā|a vai cā|u mātes apzīmēšanai Vidzemē (Vecatē, Vecpiebalgā, Drustos, Kiegelos) lieto nosaukumu cālene. Gados jaunu vistu raksturošanai Cirgalos un Džūkstē izplatīts nosaukums vistene (ME IV 626), bet Rucavā vistệna (EH II 790). Lubānas apkaimē lieto nosaukuma vistệns paplašināto formu vistalẹns (EH II 790).

Kā redzams, Latvijas teritorijā tiek lietoti dažādi nosaukumi vistas raksturošanai. Taču vislielākā nosaukumu daudzveidība vërojama Zieme|kurzemēe, Zemgalē, kā arī Zieme|austrumvidzemē. 


\section{SAĪSINĀJUMI}

Dr - Dravnieks J. Latvju-krievu vārdnīca. R., 1923.

EH - Endzelīns J. un Hauzenberga E. Papildinājumi un labojumi K.Mīlenbaha Latviešu valodas vārdnīcai. I-II. R., 1934.-1946. Konv - Latviešu konversācijas vārdnīca. l-XX. R., 1927.-1940. Ld - Latvju dainas. I sēj. - R., 1989.

LLVV - Latviešu literārās valodas vārdnīca. 1.-8.sēj. R., 1972.1996.

Lg Langijs J. Latviski-vāciskā vārdnīca ar ìsu latviešu gramatiku. R., 1936.

ME - Mīlenbahs K. Latviešu valodas vārdnīca. Red., papild., turpin. J.Endzelīns. I-IV R., 1923.-1932.

PS̆ - Latviešu tautas pasakas un teikas. Sakop. un red. P.Šmits. I sēj. - R., 1925.

St - Stender G.F. Lettisches Lexikon. Mitau, 1789.

$\mathrm{U}$ Lettisches Wörterbuch. Teil 1. Lettisch-deutsches Wörterbuch von Bischof C.C.Ulmann. R., 1872.

V - Valdemārs Kr. Krievu-latviešu-vācu vārdnīca. R., 1872.

\section{ABOUT THE NAMES OF HEN \\ IN THE VOCABULARY OF LATVIAN DIALECTS Summary}

There are many names of birds registered in the material of Latvian dialects, but the names of hen are most frequent.

This article deals with semantic and areal aspect of the names of hen. The names of hen, which have only emotional attitude to the bird, are most frequent. These names have mainly shade of endearment (for example, tita, ciba). Brooding hen has many names (for example, klukste, kludze, perele, perenica).

The other names characterize the hen according to:

1) body's measure (for example, krüpinss);

2) appearance (for example, pūcīte, pükaine, püknāsis); 
3) colour of feathering (for example, sāmale);

4) age (for example, caba, cabina).

The greatest diversity of the names of hen is in North Kurzeme, Zemgale and North-east Vidzeme. 


\section{Sarmīte LAGZDIN̦A}

MŪSDIENU PRINCIPU IZMANTOŠANAS IESPĒJAS LATVIEŠU VALODAS VĀRDŠKIRU KLASIFIKĀCIJĀ

1. Izmantojot valodas materiāla praktiskā analīzē Mūsdienu latviešu literārās valodas gramatikā (turpmāk Mllvgr) pieņemto un vēl arvien spēkā esošo vărdšḳiru klasifikāciju, bieži rodas situācija, kad kāda vārda ieskaitiššna noteiktā vārdškirāa ir problemātiska. Nevis tāpēc, ka tie vienmēr būtu t.s. pārejas zonu vārdi, kuru vārdšķirisko piederību ir objektīvi grūti izšķirt, bet galvenokārt tāpēc, ka pašāa vārdšķiru sistēmā atklājas da|ējs kritēriju pretrunīgums, baltie plankumi un neatbildēti jautājumi.

Šḳiet, ir pienācis laiks arī latviešu valodniecî̉ā pārskatīit tradicionālo vãrdšķiru klasifikācijas sistēmu. Raksta nolūks ir dot ieskatu šajā problēmā un rosināt morfologijas speciālistus tā risināšanai.

Tā kā latviešu valodniecībā pēc Mllvgr vārdškiru sistēmas izveides problēma kopumā nav apcerēta, pievērsos mūsdienu germānistikas literatūrai. Vācu valoda ir pietiekami tuva latviešu valodai, lai tur varētu meklēt atbildes vismaz uz dažiem jautājumiem. Turklāt paši vācu valodnieki uzsver, ka, atskaitot dažus konkrētus katrai valodai specifiskus jautājumus, vārdšķiru klasifikācijas problēma mūsdienās ir visu Eiropas valodu problēma.

Eiropas valodu tradicionālā vārdšḳiru sistēma nāk no antīkās tradīiijas, kur vārdšḳiras sākotnēji atvedinātas no noteiktām logiskām kategorijām. Kaut gan ar laiku veidojies mūsdienās jau neapšaubāmais priekšstats par vārdšķiru kā pašas valodas kategoriju un vārdšķiru raksturojumā iesaistîtas tīri valodiskās formālās un semantiskās pazīmes, tomēr arī mūsdienu tradicionālajā valodniecībā vārdšķiru pamatinventārs palicis tas pats sākotnējais ( 9 vai 10 vārdšḳiras ar nelielām variācijām 
konkrētâs valodās vai dažădos hronologískos posmos). Atgādināšu Mllvgr doto iedalījumu 10 vārdšķirās:

$\begin{array}{ll}\text { Patstāvīgie vārdi } & \text { Palīgvārdi (funkcionālie vārdi) } \\ \text { Lietvārds } & \text { Prievārds } \\ \text { Adjektīvs } & \text { Saiklis } \\ \text { Skaitla vārds } & \text { Partikula } \\ \text { Vietniekvārds } & \text { Izsauksmes vārds } \\ \text { Verbs } & \\ \text { Adverbs } & \end{array}$

Agrākās gramatikās dažkārt ir 9 vārdšķiras, galvenokārt tāpēc, ka netiek šķirts saiklis no partikulas, arī robežas starp tiem ne vienmēr atbilst Mllvgr skatijumam.

Šăda vai foti līdzīga vārdškiru inventăra relatīva stabilitāte dažādās valodās un ilgstošā laikposmā rada priekšstatu, ka tas ir vienīgais iespējamais vārdškiru klasifikācijas variants un ka tas vislabāk atspogu|jo objektīvos valodas faktus. Tāpēc tradicionālajās gramatikās vārdi netiek katru reizi par jaunu iedalīti vārdšķirās pēc noteikta kritērija vai kritēriju sistēmas un izstrādātas jaunas, pilnīgākas vārdškiru identifikācijas pazīmes jeb definīcijas; vārdšķiru inventārs visumā tiek pārṇemts gatavā veidā no iepriekšējām gramatikām līdz ar tradicionālajām definīcijām vai bieži pat bez kādas definīijas (kā, piemēram, J. Endzelīna "Latviešu valodas gramatikā") kā kaut kas aksiomātisks.

Kā trāpīgi izteicies L. Ščerba, šāds stāvoklis visumā apmierināja praktiskās vajadzības, tāpēc ilgu laiku "tikai retam ienāca prātā pārbaudīt tradicionālās vărdšķiru nomenklatūras pamatotību un konsekventumu" [3, 124]. Turklāt tradicionālajai vārdšķiru sistēmai neapšaubāmi ir savs racionālais kodols - par to liecina jau kaut vai tas, ka visos jaunākos klasifikācijas variantos daja tradicionālo vārdšķiru saglabājas tīrā veidā, bet pārèjās lielākoties tikai maina savu rangu, $k$ |ūstot par kādas citas 
vārdšķiras apakšklasi vai, tieši pretēji, par augstāka līmeṇa klasifikācijas vienību, kas tālāk dalās vairākās vārdšḳirās.

Un tomēr mūsdienu valodniecibas un it sevišḳi strukturālisma straujās attīstības rezultātā gadsimta otrajā pusē kJuva nepieciešams pārvērtēt vērtības arī vārdšḳiru jomā. Mūsdienu valodniecỉbas princips ir orientācija uz pašas valodas parādỉbu izpēti visā to komplicētībā un pretrunīgumā. Tai pašā laikā tiek atzīts, ka šì komplicētā un pretrunīgā izpētes objekta valodas - teorētiskajam atspogulojumam jäbūt sistēmiskam un nepretrunīgam, pretējā gadījumā tam nav pietiekamas izziñas vërtības [5, 48]. Atspogulojumam, protams, jābūt adekvātam, t.i., tam jāatklāj objekts visā tā komplicētībā un pretrunīgumā, taču stingri šķirot objekta dažādos limenus un aspektus un tikai pēc tam parādot to kopsakaríbas.

No šāda viedokla vērtējot tradicionālo vārdšksiru sistēmu, tika konstatēts, ka tâ minētās prasības neapmierina: gan vārdšḳiru aprakstā, gan pašā klasifikācijā vērojams noteikta principa trūkums, semantisk $\bar{a}$, morfolog̉isk $\bar{a}$ un sintaktiskā kritērija amorfs un nekonsekvents lietojums. Kritēriji neveido noteiktu hierarhisku sistēmu, līdz ar to pašā sistēmā vērojams zināms pretrunīgums, vārdšķiras nav pietiekami definētas un norobežotas.

2. Tradicionālās sistēmas pārvërtēšana bija stimuls dažādu jaunu vārdšḳiru klasifikāciju izstrādāšanai, n,emot par pamatu gan vienu kritēriju semantisko, morfologisko vai sintaktisko, gan dažādas to kombinācijas noteiktā hierarhiskāa secibā.

Un izrādījās, ka atkarībā no vienīgā vai primārā kritērija izvēles un tā izmantojuma konsekventuma (resp. izpratnes) var iegūt loti atšḳirīgu vārdšḳiru inventāru. Ilgu laiku savu tradicionālo seju jebkurā klasifikācijas variantā saglabāja vismaz verbs un lietvārds. Šodien jau sastopamas arī klasifikācijas, kur no verba kategorijas nodalīti atseviškşā vārdšksirā palīgverbi, un klasifikācijas, kur lietvārdi apvienoti vienā substantīvisko vārdu škirā kopā ar substantīviskajiem vietniekvārdiem. Sakarā ar 
vispārējo atteikšanos no tīri semantiskā klasifikācijas principa (par to skat. tālāk) samērā liela vienprātība ir tradicionālā skait|a vārda traktējumā pa lielākai da|ai tas pilnīgi pazudis kā atsevišḳa vārdšķira un kJuvis par semantisko grupu citu vārdšḳiru ietvaros (šo kategoriju apvieno tikai semantiskā pazìme, t.i., skaita vai secības nojēgums, formālās pazīmes liek to ieskaitīt adjektīvos, lietvārdos un adverbos). Pārējās atšķirības no tradicionālās sistēmas lielākoties vēl nav vispāratzītas, un katra no tām sastopama tikai dažos klasifikācijas variantos. Piemēram, partikulas bieži iekłautas adverbos vai otrādi (tas gan vismaz da|êjji saistīts arī ar terminoloǵijas specifiku vācu valodā, kur ar vārdu Partikel nosauc gan partikulu latviešu valodniecībā pierastajā izpratnē, gan visas nelokāmās vārdšḳiras kopā); prievãrdi un saik]i dažkārt apvienoti vienā saistītājvārdu šḳirā; citreiz saikli diferencēti divās vārdšḳirās konjunktoros un subjunktoros (jāatzīst, ka sintaktiskā atšķirība starp sakārtojuma un pakārtojuma saik|iem nav mazāk spilgta un būtiska kā sintaksẽ starp diviem galvenajiem salikta teikuma veidiem sakārtotu un pakārtotu teikumu); izsauksmes vārds te vispār izmests no vārdškíiru sistēmas, te apvienots uz sintaktiskās funkcijas līdzības pamata ar dažiem citiem vārdiem teikuma ekvivalentos.

Tātad atkarībā no izmantotajiem kritērijiem iegūst dažādu rezultātu. Te jāuzsver, ka runa ir tikai par klasifikācijas kritēriju izvēli, par paša vārdšḳiru inventāra izstrādāšanu, kur iespējamas dažādas pieejas atkarībā no valodnieka pārstāvētās koncepcijas. Neviens nenoliedz, ka pēc kāda viena principa izdalītajām vārdšḳirām pēc tam jādod pilnīgs un objektīvs visu aspektu un iespējamo pazīmju apraksts, sīkāks iedalījums semantiskajās, morfologiiskajās un sintaktiskajās apakšklasēs un to raksturojums.

O. Moska|ska nosauc vārdšķiru par tai piederīgo konkrēto vãrdu funkcionēšanas gramatisko modeli un salīdzina to ar teikuma gramatisko modeli sintaksē [3, 139]. Šiss būtiskās ipašības dē| vārdšķira ir viena no gramatikas pamatkategorijām, 
kas kā vārda raksturojums tiek attiecināta uz morfologiju, bet tai pašā laikā saista arī vārdu ar teikuma resp. sintakses līmeni.

Starp citu, vācu valodā ir izdarīts mēgìnājums registrēt visas iespējamās vārdu pazimes morfologiskajā, sintaktiskajā, logiski semantiskajā un prosodiskajā lìmenī, kuras kaut kādā zin̄ā var ietekmēt un raksturot vārdu gramatiskās funkcionēšanas ipatnỉbas [3, 127-136]. Izstrādāti 24 testi, kas ietver, piemēram, tādus jautājumus kā vārda morfologiskās kategorijas, spēja pildīt noteiktas sintaktiskās funkcijas, iespējamā pozīcija teikumā, iespējamie sintaktisko sakaru veidi, iespējamās transformācijas (piemēram, pozīijas maiña teikumā vai iespēja aizstāt attiecīgo vārdu ar semantiski ekvivalentu konstrukciju), spēja funkcionēt atsevišķa izteikuma statusā, spēja saistīties ar vienlīdzīgu teikuma locekli, iespēja eliminēt attiecīgo vārdu teikumă, dažāas tulkojuma iespējas citās valodās, spēja atbildēt uz jautājumu, spēja uzṇemt teikuma logisko uzsvaru, log̣iski gramatiskā semantika, iespējamā loma teikuma aktuālajā dalījumā un logiskā spriedumā utt. Pozitîvas atbildes gadījumā jautājumi tiek diferencēti sīkāk. lespējamo atbilžu variantu (resp. vārdu iespējamo gramatiski relevanto pazīmju) kopējais skaits šajā registrā ir 194. Protams, katram konkrētam vārdam šo pazīmju skaits ir daudz mazāks. Taču kopumā, pēc autora domām, vārdšk̨iru pilnīgā aprakstā jāuzrāda visas attiecīgajai vārdšķirai un tās sīkākajām apakšgrupām piemītošās pazīmes no šì saraksta, tikai tad pašas vārdšķiras, kā arī to semantiskās, morfoloğiskās un sintaktiskās apakšgrupas būs pilnīgi norobežotas un izsme|oši aprakstītas.

Protams, nebūtu saprātīgi izdalīt kā atsevišku vārdšķiru katru sīkāko vārdu grupu ar pilnīgi vienādām visu līmeņu pazīmēm. Vārdšķiras ir augstākā ranga iedalījums, kuru ietvaros izdalāmas grupas, apakšgrupas un tā tālāk lìdz pat individuālām īpatnībām. Tāpēc katrā vārdškirirā ir centrs un periférija. Centrā visu līmeṇu un aspektu pazīmes ir savstarpēji atbilstošas, un katra no tām izteikti norobežo attiecīgo vãrdšķiru no pārējām. Perifērijā dažu no raksturīgajām pazìnēm var nebūt, bet dažas 
var būt kopīgas ar citām vārdšķirām. Taču teorētiski definētajai vārdšķiras diferenciālajai pazīmei būtu jāpiemīt visiem attiecīgās vārdšķiras vārdiem un tikai tiem, lai neveidotos pārejas zonas, kas atbilst vairāku vārdšķiru definīcijām. Tāpēc tik svarīga ir kritēriju izvēle un to konsekvents lietojums.

3. Pēdējā laikā vairums valodnieku ir vienisprātis, ka semantiskais kritērijs neder par vienīgo vai primāro pamatu vārdšķiru klasifikācijai. Ja ar semantisko kritēriju saprot kategoriālo vispārināto nozīmi, ar kuru it kā definētas patstāvīgās vārdškiras arī Mllvgr, tad jāatzīst, ka pilnā mērā savu uzdevumu viennozīmīgi definēt vārdšķiru pilda tikai verba kategoriālā nozīme (procesualitāte) un lietvārda kategoriālā nozīme (priekšmetiskums). Jau adjektīva un adverba nošķiršanā izrādās neiespējami iztikt tikai ar semantiskiem jēdzieniem un jānem palīgā sintaktiskais kritērijs: piemēram, adjektīvs Mllvgr definēts kā vārdšķira, kas izsaka priekšmeta pazīmi, adverbs kā vārdšḳira, kas izsaka darbības, stāvokla, pazīmes pazīmi (faktiski

lietvārda resp. verba, adjektīva, adverba pazīmi; sal. lēna skriešana lēni skriet). Pārējām vārdšḳirām, it sevišḳi nelokāmām, semantikas noteikšanā vispār ir neizbēgams subjektīvisms - ja pieṇem, ka tām vispār ir šāda no leksiskām nozīmēm vispāāināta kategoriālā semantika; nelokāmās vārdšķiras praktiski tiek definētas ar sintaktisko funkciju.

Ir arī uzskats, ka katrai vārdšķirai, ieskaitot nelokāmās, ir sava gramatiskā nozīme, kas izriet no to sintaktiskās funkcijas un citām gramatiskajām īpašībām (piemēram, lietvārdam jebkura īstenibas fenomena priekšmetiskojums; vietniekvārdam - netieša references izteikšana, norādot uz citu vārdu, kas nosauc attiecīgo objektu). Šāda semantiskã klasifikācija būtu konsekventa un lielā mērā informatīva, taču jau pats apzīmējums “gramatiskā nozīne" liecina, ka tā izriet no vārdu gramatiskajām īpašībām un attiecībā pret tām ir sekundāra, tātad arī nebūtu izmantojama par vienīgo vai primāro kritēriju.

Šḳiet, ir taisnība kritiskajam atzinumam, ka neatkarīgi no savām teorētiskajām deklarācijām arī semantiskā virziena 
pārstāvji vārdšḳiras faktiski izdala pēc formāliem rādītājiem, t.i., pēc gramatiskām pazīmēm, un tikai pēc tam abstrakcijas ce|ā atrod tām vairāk vai mazāk adekvātu semantisko raksturojumu.

Ir vērts pieminēt arī dažas vispārteorētiskas atziṇas: "Kaut gan semantika pieder pie valodas iekšējās uzbūves, vēl vairāk - tā ir valodas būtība un sūtỉba, tomēr nedrīkst pētīt valodu, analizējot tās mazāk uzskatāmo un grūtāk formalizējamo aspektu semantiku, vispirms nenodarbojoties ar valodas formālo struktūru. Nozīme ir pārāk svarīga un komplicēta lieta, lai uz to balstītos valodas analīzè. Valodas pētīšanu, strukturēšanu un kategoriju izdalīšanu nedrīkst sākt ar nozīmes analīzi, tā ir jānoslēdz ar nozīmes analīzi kā valodas analīzes augstāko pakāpi." [3, 123-124] Un: “Jāpētī, kā valoda pati sadalās vārdšķirās, ko konkrētā valoda šķir un ko nešksir. Pats par sevi saprotams, ka šādām [t.i., objektīvām - S.L.] kategorijām obligāti piemīt arī formālās pazīmes. Ja tādu formālu pazīmju nav [t.i., ir tikai eventuāla semantiska atškiriba - S.L.], valodas sistēmā nav arī attiecīgas kategorijas." [3, 124]

4. No teiktā jau skaidrs, ka vispāratzīts kluvis uzskats par gramatisko kritēriju kā vienīgo ce|u, kas principā jauj iegūt objektīvu, izsme|ošu un nepretrunīgu vārdšķiru klasifikāciju. Te gan jāpiebilst, ka šāds secinājums iegūts, nodarbojoties galvenokārt ar nelokāmo vārdšḳiru klasifikācijas problēmām. Lokāmajām vārdšḳirām visumā piemīt semantikas, morfolog̉ijas un sintaktiskās funkcijas paralēlisms, tā ka līdzīgu rezultātu teorētiski var iegūt, izejot no jebkura kritērija.

Gramatisko kritēriju nosacīti var sadalīt morfologiskajă un sintaktiskajā, kas gan ir funkcionāli cieši saistīti, tomēer analīzē norobežojami. Tāpēc teorētiski pastāv jautājums, kurš no tiem vai varbūt abi būtu ṇemami par pamatu vārdškiru klasifikācijai. Samērā viegli ir atrisināms jautājums, vai morfologiskais kritērijs var būt par vienīgo. Acīmredzot tas nebūtu lietderīgi, jo visi vārdi bez morfologiskās formu sistēmas veidotu vienu vārdšķiru. Turklāt morfologijiskās pazīmes nav 
būtiskākās, tās nav pašmērḳis, bet tikai mehānisms, kas nodrošina vārdu funkcionēšanu teikumā.

Atliek divi vārdšķiru klasifikācijas principi, kas arī dominē, piemēram, vācu valodniecỉbā. Viens no tiem ir klasifikācija pēc tîri sintaktiskā kritērija. Šis kritērijs ir spējīgs raksturot jebkuru vārdu (katrs vārds kaut kādā veidā funkcionē teikumā vai pats veido teikuma analogu). Tas ir universāls un absolūti konsekvents kritērijs, kas ir pietiekams visām vārdšķirām, bet da|ai (nelokāmajām vārdšḳirām) pat nepieciešams. Turklāt sintaktiskais kritērijs būtībā ietver sevī arī visus pārējos, jo sintakse ir līmenis, kurā izpaužas vārda formu sistēmas un semantikas potences. Taču sintaktiskais kritērijs, pirmkārt, ir vismazāk uzskatāmais (sintaktiskā funkcija ir samērā augstas pakāpes abstrakcija), otrkārt, ar to iegūtā vārdškiriru sistēmā ir neizbēgamas būtiskas atšķirības no tradicionālās sistēmas, kurā sintaktiskais kritērijs ir pakārtots semantiskajam un morfologiskajam.

Piemēram var derēt G. Helbiga vācu valodai izstrādātā 7 vārdšķiru sistēma $[5,38]$ : verbs, substantīviskie vārdi (apakšgrupas lietvārds, substantīviskais vietniekvārds), adjektīvs (ieskaitot adjektīviskos skait]a vārdus), adverbs, 1. tipa funkcionālie vārdi (artikuli jeb lietvārda pavadoni, ieskaitot adjektīviskos vietniekvārdus), 2. tipa funkcionālie vārdi (saistītājvārdi; apakšgrupas prievārdi, saikḷi), 3. tipa funkcionālie vārdi (adverbiem līdzīgie vārdi; apakšgrupas partikulas, modālie vārdi, teikuma ekvivalenti, ieskaitot izsauksmes vārdus). Šajā klasifikācijā ievērots princips izdalīt pēc iespējas mazāk primārā dalījuma klašu jeb vārdšḳiru (daudzas apakšgrupas atbilst vārdškirām tradicionālajā izpratnē).

Otrs mūsdienās atzītais princips ir vārdšḳiru klasifikācija pềc morfolog̀iskā kritērija lokāmiem vārdiem un pēc sintaktiskā kritērija nelokāmiern vārdiem. Tă kā morfologiskie rādītāji ir tieši uztverami un uzskatāmāki nekā abstraktās sintaktiskās attieksmes, šĩ pieeja lauj vienkāršot lokāmo vārdšksiru definīcijas. Kombinēto morfologisko un 
sintaktisko kritēriju var nosaukt arī par vienotu gramatisko kritēriju, kura ietvaros atkarībā no konkrēto vārdu îpatnībām priekšplānā tiek izvirzīts viens vai otrs gramatiskā kritērija aspekts. Gramatisko kritēriju, sākot ar morfologisko un beidzot ar sintaktisko, izmanto, piemēram, V. Flēmigs, secīgi iegūstot 9 värdšķiras [2, 356-359]: vispirms vārdi tiek dalīti konjugējamos (verbs) un nekonjugējamos; nekonjugējamie tiek dalīti deklinējamos un nedeklinējamos, deklinējamie tālāk pēc papildu morfoloğiskām paz̄mēm (lietvārds, adjektīvs, vietniekvārds), nedeklinējamie - tālāk pēc sintaktiskām pazīmēm (modālvārds, adverbs, partikula, prievārds, saiklis). Interjekcijas šajā sistēmā vispār neietilpst (jo "tās nav vārdšḳiras gramatiskā nozīmē").

Teorētiskā aspektā šãdas pieejas mīnuss ir tas, ka, konsekventi lietojot morfoloǵisko kritēriju kā primāro, visi nelokāmie elementi, ko esam raduši ietvert, piemēram, lietvārda vai adjektīva kategorijā (Tartu, rozā), nonāktu pie nelokāmiem vārdiem, kur tiem saskaṇā ar sintaktiskajām funkcijām un nozīmi (un arî̀ mūsu izjūtu) faktiski nemaz nebūtu vietas; savukārt, modificējot morfologiski iegūtos rezultātus atkarỉbā no sintaktiskās funkcijas (piemēram, uz sintaktiskā lietojuma analogijas pamata ievietojot nelokāmo Tartu tai pašā vārdšḳirā kả $R \bar{g} g a$, rozā - turpat kur zalš utt.), gramatiskais kritērijs k|ūst par formālu, tikai didaktisku apsvērumu nosacītu izkārtni sistēmai, kas faktiski klasificēta pēc sintaktiskā kritērija. Tomēr šāds kompromiss nav apriori noraidāms, jo vārdšķiru klasifikācijas sistēmai jāatbilst ne tikai noteiktām teorētiskām prasībām, bet jābüt arī pietiekami vienkāršai, pārskatāmai un praktiski lietojamai.

Cenšoties organiski apvienot sintaktisko un morfologisko kritēriju, U. Engels izstrādājis vācu valodai vārdšķiru klasifikāciju pēc distributīvā kritērija, par izejas punktu ṇemot vārda celmu, bet gramatisko kategoriju formālos rādītājus (galotnes utt.) uzskatot par distribūcijas elementiem [1, 18-19]. Līdz ar to morfologiskie formanti tiek nostādīti vienă 
līmen̄i ar vārda sintaktisko apkaimi tiešā nozīmē. Šajā klasifikācijā ievērotas visas būtiskās distribūcijas atšḳirības jau primārajā dalījumā, tādējādi iegūstot 15 vārdšķiras: verbi, lietvārdi, determinatīvi (tradicionālie adjektīviskie vietniekvārdi u.c. lietvārda pavadoṇi), adjektīvi, vietniekvārdi (tradicionālie substantīviskie vietniekvārdi), prievārdi, subjunktori (pakārtojuma saik|i), konjunktori (sakārtojuma saik|i), adverbi, modālpartikulas (atbilst dažu citu klasifikāciju modālvārdiem), vēl trīs vācu valodai specifiskas partikulu sintaktiskās klases (atšķiras ar iespējamo pozīciju teikumā; latviešu valodā tās, domājams, būtu apvienojamas vienā partikulu klasē), saitinpartikulas (sal. latviešu bail, żēl), teikuma ekvivalenti.

Vēl gribētos pieminēt vācu valodnieces N.Nauas 12 vārdšḳiru klasifikāciju pēc gramatiskā kritērija, kas ir interesanta ar to, ka izstrādāta tieši latviešu valodai $[4,9-10]$ : verbi, palīgverbi, saitinas, lietvārdi, adjektīvi, vietniekvārdi, adverbi, predikatīvi (atbilst U. Engela saitiṇpartikulām), kvantificējošie vārdi (pāris, daudz u.tml.), adpozīcijas, saik|i, partikulas.

Kā redzams no iepriekšējiem piemēriem, arī viena un tā paša kritērija ietvaros pastāv izvēle starp vārdšķiru sistēmu ar minimālu primāro kategoriju skaitu un detalizētāku sistēmu, kur citu sistēmu vārdšķiru apakšgrupas var parādīties kā atsevišḳas vārdšḳiras. Rezultāts atkarīgs no tā, kādā dzilumā jeb apjomā primārās klasifikācijas stadijā ṇem sintaktisko kritēriju: tikai vārda sintaktisko funkciju, arī distribūciju, t.i., pozīciju teikumā un iespējamos saistījumus, vai arī t.s. dzi|ās struktūras sintaktiskās īpatnības, kas nav konstatējamas virsējā struktūrā un atklājas tikai transformācijās.

5. Acīmredzot arī latviešu valodā pastāv iespēja veidot dažādas vārdšķiru sistēmas vai nu tieši pēc kāda no minētajiem vai citiem paraugiem, modificējot to atbilstoši latviešu valodas īpatnībām, vai izstrādājot pilnīgi jaunu sistēmu, un katrai no tām būtu savas priekšrocỉbas un savi trūkumi. Taču attiecībā uz latviešu valodu būtisks ir arī fakts, ka latviešu valodniecībā - ja atskaita jau minēto N. Nauas izstrādāto klasifikāciju - vēl vispār 
nav izdarīti mēǵinājumi pārskatīt tradicionālo vārdšḳiru sistēmu un piedāvāt citu variantu, nemaz nerunājot par vairākiem konkurējošiem variantiem (jāpiebilst, ka tam nav arī nepieciešamo teorētisko un praktisko priekšdarbu). Citiem vārdiem, latviešu valodniecībā vēl nav mūsdienu vārdšḳiru klasifikācijas tradīcijas. Tāpèc katra jauna vārdšḳiru sistēma vismaz sākumā pretendēs uz vienīgās statusu, un mums jābūt piesardzīgiem, lai nezaudētu pēctecību, t.i., lai neradītu pārāk lielu plaisu starp līdzšinējo, tradicionālo vārdšķiru sistēmu un varbūtējo jauno sistēmu, kaut arī tās pamatā būtu nevainojami zinātniski principi. Acīmredzot pagaidām jācenšas maksimāli saglabāt tradicionālo vārdšḳiru inventāru un nosaukumus, mainot kaut ko tikai tad, ja paši valodas fakti to nepieciešami prasa; jaunievedumi būtu atstājami galvenokārt vārdšķiru definīcijām resp. norobežošanai, $k \bar{a}$ arī apraksta metodikai, ieviešot tajā konsekvenci un sistēmiskumu.

Vienu šādu "piesardzīgu" latviešu valodas vārdšksiru klasifikācijas sistēmu es gribētu piedāvāt. Pašlaik gan tā ir tikai empīriska pagaidu klasifikācija mana tiešā darba (vienkārša teikuma sintakses) vajadzībām. Tāpēc, ja arī šì sistēma tiktu visumā akceptēta, tā vēl būtu jāpamato teorētiski un pašas vărdšķiras jādefinē. Taču, manuprāt, šī klasifikācija atspogu|o vienu no variantiem, kā latviešu valodas vārdu krājums pats dalās gramatiskajās klasēs. Tā pamatā ir vārdu sintaktiskāa uzvedība, tātad tā ir viena no sintaktiskās klasifikācijas iespējām, kas visumā atbilst arī kombinētajai morfoloğiski sintaktiskajai (gramatiskajai) klasifikācijai.

Ilustrēšu šo variantu, aplūkojot tikai atšķirības no tradicionālās vārdšḳiru sistēmas.

1. Atsevišksā vārdšķirā būtu izdalāmi modālvārdi noteikti, varbüt, laikam, neapšaubāmi, patiesībā, cerams, škiet, diemžēl, patiešām, šķietami, dabiski, acīmredzot u.tml. Morfologiiski tie atbilst adverbiem vai citu vārdšḳiru vārdiem un to formām un bieži ir homonīmi konkrētiem citu vārdšḳiru vārdiem (ši homonīmija ir viens no argumentiem par labu 
modālvārdu izdalī̌anai), virsējā sintaktiskajā struktūrā tie novietojas līdzīgi adverbiem. Taču atškirībā no homonìmajiem citu vārdšķiru vārdiem, kas funkcionē kā teikuma faktiskā jeb propozitìvā satura komponenti, modālvārdi reprezentē atsevišķu dzịās sintaktiskās struktūras teikumu, kurā izteikts runātāja subjektīvs vērtējums par teikuma propozitīvo saturu (par to liecina jau modālvārdu nozīmes atšķirỉba no homonīmajiem vārdiem). No šīs modālvārdu būtības izriet arī to pārējās sintaktiskās īpatnības: piemēram, tie pie|auj transformāciju, kurā modālvārda saturs ietverts virsteikumā, bet izejas teikuma propozitīvais saturs - palīgteikumā (Viñš patiesībā to vēl nezina $\rightarrow$ Patiesībā ir tā, ka vinsš to vēl nezina); ar modālvārdu bieži var atbildēt uz vispārīgo jautājumu (Vai vin̄š atnāks? - Laikam); modālvārdi (it sevišḳi ar citām vārdšḳirām homonīmie) bieži ir savrupināti no pārējā teikuma vai pat vienmēr parādās savrupinātā pozīcijā (Tā patiesi būs labāk / Patiesi, tā būs labāk; Vinš, cerams, atnāks); modālvārdi teikumā nav noliedzami ( Viņš ne laikam atnāks; *Vinšs, ne cerams, atnāks), tiem nav arī leksisko atvasinājumu ar ne- vai arī šie atvasinājumi zaudē modālo funkciju (laikam - *nelaikam, šksietami - ${ }^{*}$ nešķietami, noteikti nenoteikti, dabiski nedabiski utt.; izñēmums neapšaubāmi, kam savukārt modālvārda funkcija ir tikai noliegtajā formā); modālvārdi nemēdz veidot vienlīdzīgus teikuma loceklus ("neapšaubāmi un acīmredzot, *varbūt un cerams, *noteikti, bet diemžél).

Tādu vārdu katrā valodā nav daudz, tiem analogu funkciju bieži veic frāzes vai teikumi ( $k a \bar{m}$ man šķiet, pats par sevi saprotams, var gadities utt.).

2. Interjekcijas būtu iesaistāmas gramatiskajā vārdšķiru sistēmā, ieklaujot tās teikuma ekvivalentos kopā ar dažām līdzšinējām partikulām - apgalvojuma / nolieguma vārdiem $j \bar{a}$, $n \bar{e}$ un vārdiem $l \bar{u} d z u$, paldies kā atbildes reakciju (līdzīgā funkcijā kā $j \bar{a}, n \bar{e}$ ). Visi šie vārdi vienmēr veido atseviškŭu izteikumu un neieklaujas teikuma struktūrā arī tad, ja tie lietoti kopā ar teikumu. Vēl būtu apsverams jautājums, vai vokatīvs arī 
jek|aujams šajā vārdšḳirā vai uzlūkojams par lietvārda formu ar specifisku (izteikuma) funkciju.

3. Lokāmo vārdšḳiru grupā nepieciešams jauninājums šḳiet skait|a vārda kā atsevišḳas vārdšḳiras likvidēšana un attiecīgo vārdu ieskaitīšana tajās vārdšḳirās, kurām tie piederīgi pēc formālajām pazīmēm, t.i., galvenokārt adjektīvos (argumentācija jau aplūkota raksta sākuma da|āa). Protams, skait|a vārdiem ir arī savas funkcionālās īpatnības, tāpēc tie ir nozīmīga un îpaši izdalāma adjektīvu semantiskā un sintaktiskā apakšgrupa.

4. Visbeidzot jārunā nevis par jauninājumu, bet par kāda jauninājuma trūkumu. Kā jau redzējām, konsekventas sintaktiskās klasifikācijas aizstāvji uzskata par nepieciešamu likvidēt arī vietniekvārdus kā atsevišḳu vārdšķiru, jo tie izdalīti tikai pēc semantiskās pazīmes. Tomēr domāju, ka vietniekvārdi būtu saglabājami kā atsevišḳa vārdšḳira, un tā būtu tikai šķietama atkāpe no sintaktiskā klasifikācijas principa, jo sintaktisko kritēriju nebūtu nepieciešams ierobežot ar teikuma līmeni, kur vietniekvārdi funkcionē līdzīgi lietvārdiem un adjektīviem. Vietniekvārdu sintaktiskās īpatnības nepārprotami atklājas teksta lïmenĩ. Tiem ir specifiska distribūcija tekstā vai situācijā, piemēram, anaforiskajiem vietniekvārdiem tas, tăds ir obligāts attiecīgā objekta vai pazīmes nosaucošs apzīmējums iepriekšējā kontekstā un līdz ar to noteikta pozīcija teksta vienỉbu secībā (otrais un tālākie teikumi), vai arī tiem ir specifiska distribūcija objektīvajā īstenībā tiešs attiecīgā objekta tuvums ( $T \bar{a}$ ir skola - ja skola ir redzama sarunas dalībniekiem); savukārt personu vietniekvārdiem es, $t u, m \bar{e} s, j \bar{u} s$ vienmēr ir specifiska distribūcija komunikācijas situācijā (klausītāja klātbūtne).

Vēl jāpiebilst, ka vietniekvārdu traktējumā jāatrisina kāda problēma, kas literatūrā jau kritiski apcerēta tradicionālās vārdšķiru sistēmas sakarā: tādas pašas semantiskās un sintaktiskās pazīmes piemīt arī dažiem adverbiem t.s. proadverbiem (tur, tad, toreiz, turpat, tā u.tml.), un, ja vispār 
izdala vietniekvārdus, tad tajos būtu jāieskaita arī šie aizstājējadverbi. Domājams, ka risinājums atkarīgs no tā, vai primārajā iedalījumā izmanto tīri sintaktisko kritēriju vai ṇem palīgā arī morfologisko kritēriju, kas lautu attiecināt vietniekvārda jēdzienu tikai uz lokāmiem vārdiem. Bet šis nav vienīgais vārdšḳiru norobežošanas jautājums, kas jaunas sistēmas ietvaros var gūt netradicionālu risinājumu.

Korigèjot tradicionālo sistēmu saskañā ar minētajiem apsvērumiem, iegūstam vārdšḳiru sistēmu ar šădām 10 augstākāā ranga kategorijām:

Lietvārds

Adjektīvs

Vietniekvārds

Verbs

Adverbs
Modālvārds

Prievārds

Saiklis

Partikula

Teikuma ekvivalents

\section{LITERATŪRA}

1. Engel U. Deutsche Grammatik. 2., verbess. Aufl. Heidelberg, 1988.

2. Flämig W. Grammatik des Deutschen. Einführung in Struktur- und Wirkungszusammenhänge. Berlin, 1991.

3. Helbig G. (Hrsg.) Beiträge zur Klassifizierung der Wortarten. Leipzig, 1977.

4. Nau N. Latvian (Languages of the world / Materials 217). München; Newcastle, 1998.

5. Степанова М. Д., Хельбиг Г Части речи и проблема валентности в современном немецком языке. Москва, 1978. 


\section{MÖGLICHKEITEN DER ANWENDUNG MODERNER PRINZIPIEN \\ DER WORTARTKLASSIFIKATION IM LETTISCHEN \\ Zusammenfassung}

In der lettischen Grammatik ist noch immer das herkömmliche Wortartensystem gängig, das den Forderungen der modernen Sprachwissenschaft nach Systemhaftigkeit und Widerspruchslosigkeit nicht entspricht. Da eine neue lettische Grammatik im Institut für lettische Sprache erarbeitet wird, bedarf auch die bisherige Wortartklassifikation einer Überprüfung. Im Artikel wird eine Übersicht über die modernen Klassifikationsprinzipien der Wortarten gegeben, die durch die im Rahmen der Germanistik erarbeiteten Klassifikationen illustriert wird. Eine Klassifikationsvariante der Wortarten für das Lettische wird proponiert und begründet. 


\section{Daina NITTIN̦A VERBU PAMATFORMAS UN VERBU LOCİ̌sANA}

Izvērtējot latviešu valodas verbu formu sistēmu, atzīts, ka tās pamatu veido 3 formu tipi jeb 3 celmi, no kuriem tiek veidotas visas pārējās verbālās formas. Šo pamatu tradicionāli sauc par pamatformām, un to veido nenoteiksmes, tagadnes un pagātnes formas. Nenoteiksme ir nelokāma forma, un tā tad arī ir tradicionāli pirmā nosauktā pamatforma: celt, celties. Formu veidošanā gan izmanto nevis pilnu pamatformu, bet tās celmu, ko dabū, atmetot galotni $t$ vai attiecīgi refleksivvajiem verbiem -ties: cel-t-cel-dams, cel-ties - cel-damies.

Tagadne un pagātne mainās personu formās, kas atšķiras ne tikai pēc galotnēm vien, tāpēc pastāv problēma, tieši kuru no personu formām izraudzīt attiecīgi par tagadnes vai pagātnes pamatformu. Latviešu valodniecībā nostiprinājusies trađīijja par pamatformu izmantot vienskait|a vai daudzskaița pirmās personas formu.' Praksẽ, dodot pamatformas, parasti tiek minēta vienskait|a pirmās personas forma: celt - celu - cèlu, lasìt - lasu - lasīju. Domājams, tā šķitusi parocīgāka. Tieši pirmās personas formas izvēli vispār noteikuši formāli faktori, tas, ka šĩ forma, resp., tās celms noder visos pārējo formu veidošanas gadījumos bez izṇèmumiem.

Tomēr pirmās personas formas izmantošana rada kā semantiskas, tā formālas neērtības galvenokārt šādu iemeslu dē|:

1) latviešu valodā ir daudz darb̄ibas vārdu, kurus parasti (izṇemot vien̄igi dzeju un citus poētiskos tekstus) pirmajā personā nelieto, tāpēc dažkārt tradicionālā pamatformu nosaukšana ir diezgan amizanta, piem.: līt - listu - liju, snigt sniegu snigu, apmākties apmācos apmācos, atlüzt atlūstu, atlūzu, aust - austu - ausu. Lai no tā izvairītos, autori

\footnotetext{
' Mūsdienu latviešu literārăs valodas gramatika, I. - R., 1959. - 665. lpp.
} 
visbiežāk atsakās no regulas un nosauc 3.personas formu, piemēram: $b a d / \bar{t} t$, 3.p. $-a$, pag. $-\bar{i} j a ;^{2}$

2) diezgan bieži tieši vienskait|a pirmās personas formas tagadnè un pagātnē sakrīt, piem.: braukt brancu braucu, aptumšot - aptumšoju aptumšoju, atkarāties atkaräjos atkarājos, un līdz ar to tās nekādu papildus informāciju nesatur;

3) atšḳirībā no pirmās personas formu ierobežotības lietošanas ziṇā savukārt tieši trešās personas formas valodā ir visbiežāk lietotās, turklāt pastāv tikai viena kopīga forma, kas neatšķiras vienskaitlī un daudzskait $\bar{i}$.

Visus verbus latviešu valodā var lietot trešajā personā vai tikai šajā personā, piemēram, vajadzêt - vajag - vajadzēja, tāpēc logiski ir izraudzīt to par tagadnes un pagātnes pamatformu. N̦emot 3. personu par pamatformu, tagadnes un pagātnes celmu noteikšanā ir jāievēro šādi nosacījumi:

1) ja tiešie darbības vārdi 3. personā beidzas ar līdzskani, šì forma ir tagadnes celms, piemēram: skrien, lūst, lauž, peld, grib;

2) trešās personas galotne $-a$ ir raksturīga ne vien visiem tiešajiem verbiem pagātnē, bet tā var piemist arī tiešajiem verbiem tagadnē; to atmetot, attiecīgi iegūst vai nu tagadnes, vai pagātnes celmu, sal., piemēram, las- $a>$ las (tagadnes celms) lasijj-a > lasīj (pagātnes celms);

3) atgriezenisko verbu tagadnes / pagātnes celmu iegūst, atmetot refleksīvo galotni -as vai -äs, sal., piemēram, piecel-as > piecel (tagadnes celms) - piecēl-ās > piecēl (pagātnes celms), sasveicin-ās > sasveicin (tagadnes celms) - sasveicinäj-ās > sasveicinäj (pagātnes celms);

4) ja 3. personas forma tagadnē beidzas ar garo patskani vai divskani $-o$, tagadnes celmu veido, pievienojot $-j$, piem.:

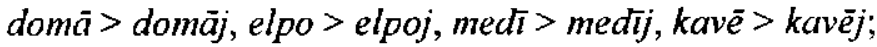

5) neregulāri (ne no 3. personas) ir veidojami divu nekārtno verbu tagadnes celmi, proti: verba "būt" tagadnes celms ir "es" - es-mu, es-am, "iet" - "ej" - ej-u, ej-iet.

'Latviešu valodas pareizrakstỉbas vārdnīca. - R., 1981. 
Tikko minēto nosacījumu aprakstu var vienkāršot, norādot, ka tagadnes vai pagātnes celmu veido attiecīgi tagadnes / pagātnes 3.personas forma, kurai vai nu atmet galotni -a/-as/ -ās, ja tāda piemît, vai pievieno $-j$, ja forma beidzas ar garo patskani vai divsakni $-o$, piemēram,

tagadnes celmi: bēg, $\bar{e} d$, nes, tin, liek, sien, auj, kräj, kāpj, pūss, līst, dod; gaid(a), modin(a), kavēj(as), main(ās); $r u n \bar{a}+j(-u,-a m,-a t), k l u s \bar{e}+j, d a b \bar{u}+j, c i e n \bar{\imath}+j$ (cienīj-ams) vai mūsdienās arī-cien $(a), k u \dot{g} o+j(k u \dot{g} o j-a m s)$;

pagātnes celmi: $b \bar{e} g(a), \bar{e} d(a), \operatorname{lik}(a), \operatorname{sēj}(a), k a \bar{p}(a)$, $p \bar{u} t(a), \operatorname{dev}(a), \operatorname{gāj}(a), \operatorname{bij}(a), \operatorname{gaid} \bar{j}(a), \operatorname{modināj}(a) ; k a v \bar{j}(\bar{a} s)$, mainīj(ās); runāj(a), klusēj(a), dabüj(a), cienīj(a), kugioj(a).

Izṇèmums ir tagadnes celmi no "būt" - es- (es-ošie) un "iet" $-e j-(e j-a m s)$.

Latviešu valodā ir liela pamatformu dažādība, jo nenoteiksmes, tagadnes un pagātnes celmi savstarpēji atšķiras gan ar skaṇu - patskaṇu un lĩdzskañu - miju, gan izmantotajiem piedēkliem. Tradicionāli šîs atšǩirỉibas tiek nemtas vērā, nosakot darbības vārdu konjugācijas un grupas. ${ }^{3}$ Taču pastāv dažādas pieejas un dažādi latviešu valodas verbu pamatcelmu aprakstī̌sanas un sistematizēšanas modeli ${ }^{4}$

${ }^{3}$ Sk., piemēram: Mūsdienu latviešu literārās valodas gramatika, I. - R., 1959. - 667.-681. lpp.

${ }^{4}$ Sal., piemēram, Endzelīns J. Latviešu valodas gramatika. - Rīga: LVI, 1951. 717.-885.lpp; Fennel T.G., Gelsen H. A Grammar of Modem Latvian. Vol. 1-3. The Hague - Paris New York: Mouton Publishers, 1980. - 527.-529. 906.-909. lpp.; Fennels Tr. Jauna latviešu valodas pirmās konjugācijas verbu klasifikācija // Lingua Lettica. Raksti latviešu lingvistikā. - Melburna, 1995. - 23.38. Ipp.; Andronovs A. Pārdomas par verba locī̌sanu latviešu valodā. - LZA Vēstis. - 1997. - 51. sēj. - Nr. 3./4. - 30.-35. Ipp.; Andronov A. $\mathrm{K}$ probleme slovoizmenite|nyk klassov glagolov $v$ latyšskom jazyke // Materialy XXVIl mežvuzovskoi konferencii, vyp. I. Sekcija baltistiki. Tezisy dokladov. - Sankt-Peterburg, 1998. -4.-5. Ipp. 
Cilvēks, kam latviešu valoda ir dzimtā valoda vai kas to pilnībā pārvalda, pamatformas var nosaukt automātiski. Pretējā gadījumā tās ir jāatrod vai jāmācās, izmantojot vārdnīcas vai gramatikās doto formu sarakstus. Un šajā procesā nelīdz konjugāciju un grupu zināšana, jo tradicionālā konjugāciju un grupu noteikšana izriet no pamatformu kvalitātes, to pārvaldīšanas un ne otrādi.

Zinātniski ir loti svarīgi fiksēt visus iespējamos pamatformu paveidus to savstarpējās sakarỉbās, atrast optimālāko to sistematizēšanas modeli. Taču tradicionālais pamatformu sasaistījums ar konjugēšanas sistēmu personu formu paradigmu, manuprāt, ir mākslīgs, jo personu formas tiek veidotas, ṇemot pamatcelmus kā jau ko gatavu. Tāpēc šajā rakstāa tiks aplūkota verbu locīšana jeb konjugēšana, ar to saprotot tieši personu formu paradigmas izveides ipatnibas. Verbu locīšanas tipi rakstā lìdz ar to noteikti pēc galotñu izmantošanas, to esamības vai neesamỉbas un celma pārmaiṇām, veidojot atsevišksas personu formas.

\section{Tagadnes konjugācijas}

Tagadnes konjugācijām jeb locīšanai tagadnē kopumā raksturīgas šādas pazīmes:

1) neatkarīgi no patskanu $e, \bar{e}$ kvalitātes tagadnes celmā vienskait|a 2. personā tiek lietots šaurais patskanis, sal.: tagadnes celms nẹs - 2. pers. nes. Izṇēmums ir gadījumi, kad platā $e, \bar{e}$ lietojumu fonētiski nosaka sekojošais piedēkla patskanis vaj divskanis: elpo, bēgulo;

2) verbiem, kuru tagadnes celmā realizējas lìdzskaṇu mija $p-p j, b-b j, m-m j, s-\check{s}, z-\check{z}, l-l, t-\check{s}, d-\check{z}$, vienskait|a 2.personā š̄ mija nenotiek, sal.: viñs kopj - tu kop, viņš glābj - tu glāb, viņš

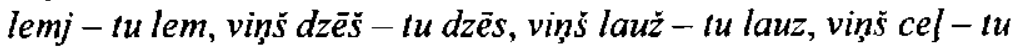

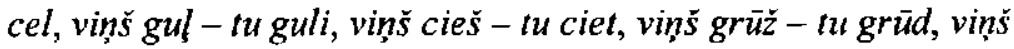
sēžz - tu sèdi.

Tagadnē latviešu valodas tiešajiem verbiem pēc to personu formu veidošanas atšķirībām ir nosakāmas 5 
konjugācijas. Lielāka vienveidība tagadnē vērojama refleksīvo darbības vārdu locīšanā, jo tiem piemīt tikai trīs paveidi. Tos var aplūkot atsevišķi $k \bar{a}$ trīs atgriezenisko verbu tagadnes konjugācijas. Tomēr atgriezenisko verbu locīšanu var aplūkot arī saistībā ar formāli un semantiski atbilstošo tiešo verbu konjugāciju, kā tas darīts šajā rakstā. Vadoties pēc šādiem principiem, var atzīt, ka sava atbilstoša atgriezenisko personu formu paradigma piemīt 1., 2. un 4. konjugācijai. Refleksīvie verbi, kas atbilst 3. un 5. konjugācijas tiešajiem verbiem, pēc personu formu veidošanas nav atškirīigi un sakrīt ar 2 . konjugācijas paradigmu. Tātad pastāv pieci tiešo verbu locišanas tipi, bet, tā kā trijiem no tiem atbilst sava atšḳirīga atgriezenisko verbu paradigma, pavisam var runāt par 8 darbības värdu locīšanas paveidiem tagadnē.

\section{Tagadnes 1. konjugācija}

\section{Tiešie verbi}

Tiešo verbu tagadnes 1 . konjugāciju var dēvēt par pilna tipa konjugāciju, jo tajā ir saglabājušās visas personu galotnes. Daudzskaitlī šai konjugācijai raksturīgs garais patskanis $-\bar{a}-1$. un 2. personas galotnē.

Locīšanas paraugs:

$$
\begin{array}{cc}
\text { es lok-u } & \text { mès lok-ām } \\
\text { tu lok-i } & \text { jūs lok-āt } \\
\text { vinšs, vini lok-a }
\end{array}
$$

Pēc šì parauga loka, piemēram, verbus: mocĭ, lasît,

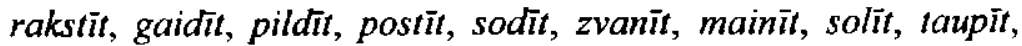
tīrìt, modināal, sveicināt, audzināt, drošināt, mierināt, mèg̀ināt, cildināt, vēdināt, kūpināt. Par piederīibu pie 1. konjugāaijas liecina 3. personas forma - tagadnes pamatforma, kas beidzas ar galotni $-a$. Tie ir darbības vărdi, kuri nenoteiksmē beidzas ar $-\bar{i} t$, -ināt.

Kā liecina tagadnes pamatforma, dala no verbiem ar $-\bar{l} t$ ne vien izloksnēs, bet arī modernajā rakstu valodā var tikt 
konjugēta kā pềc pirmās, tā 5 . konjugācijas parauga, sal.: viňs ciena/cienī, mẹera/mèrī, pẹlna/pelnī, pệta/pètī, vẹlta/veltī, vêssta/vêstī, vệta/vêtī, tirda/tirdī; līdzīgi arī: viñš sarga vai sargā. Tâtad literārajā valodā šo verbu personu formu lietošanā joprojām vērojamas svārstības, piem.: Visi $p \bar{e} t a, k \bar{a} t \bar{a}$ vētra melnu padebesi kul. Vāc. Gamma 85. Man a p p $\bar{e} t \bar{l}$ ausis, un skaidrs: Vācietis atkal lìdz baltām pelîtēm. Vāc. Gamma 114. Un čāpo uz veikalu nedzeja, un cenas kā zvaigznes $p \bar{e} t a$. Vāc. Gamma 175. Lai viňš vismaz dažas sēklas Sēklai p a p $\bar{e} t \bar{t}$, Nem un ietin avizzē Un ieliek skapititi. Zied. Kā svece 94.

Atbilstoši literārās valodas normām pēc 1.konjugācijas parauga lokāms verbs zināt: zin-u, zin-i, zin-a, zin-äm, zin-āt. Taču paralēli šīm formām sastopama īsināto formu paradigma jeb locīšana pēc 2. konjugācijas parauga: $z i n-u, z i n-i, z i n, z i n-a m$, zin-at. Sal., piem.: Un tad vēl Pētersons z in stāstīt.. Ko tāds saimniekdèliņš z i n a no Rīgas? Grīns Dvēs. 99. Dieviñš to $z$ in Vai viņš jau z in a? Veselis Proza 23, 62. Tagad neviens n e z in a, ka favorīi slimi. A.Egl. Lugas 119. Tāda svītra kaut ko z in par sevi. M.Kroma Stāvā 29. Kamikadzes ne z in ceju atpakal. Vāc. Gamma 81.

\section{Atgriezeniskie verbi}

Atgriezenisko verbu tagadnes 1. konjugācijai ir raksturīgs garais patskanis $-\bar{a}-3$. personas un daudzskaitja 1 . un 2. personas galotnē.

Locīšanas paraugs:

$\begin{array}{cr}\text { es šaub-os } & \text { mès šaub-ämies } \\ \text { tu šaub-ies } & \text { jūs šaub-äties } \\ \text { vings, viņi šaub-äs }\end{array}$

Šo konjugācijas tipu nosaka pēc tagadnes pamatformas, t.i., 3. personas garās galotnes $-\bar{a} s$. Pie tagadnes 1.konjugācijas pieder, piemēram, šădi refleksīvie verbi: svaidñties, turpināties, lìdzināties, sasveicināties, sarakstīties, vingrināties, klausīties, cìnities, lielīties, rosîties, svārstīties. Tie ir darbības vārdi, kas nenoteiksmē beidzas ar -îties, -ināties. Paralēlformas 3. personă 
ir atgriezeniskajam verbam sargāties - sarg-ās/sargāj-as. ${ }^{5} \mathrm{Li} d z$ ar to šo darbibas vārdu tagadnē loka vai nu pēc 1 . vai 2 . atgriezenisko darbības vārdu konjugācijas parauga.

\section{Tagadnes 2. konjugācija}

\section{Tiešie verbi}

Raksturīga šās konjugācijas pazīme ir vienas personu formas - 3. personas galotnes - $a$ zudums. Lìdz ar to pamatforma un pamatcelms ir identi. Papildus atzīmējams tas, ka atškiriribā no 1. konjugācijas tagadnes tiešo verbu 2 . konjugācijā daudzskait|a 1. un 2. personas galotnē ir ìsais patskanis -a-. Taču šì pazīme 2.konjugācijai ir kopēja ar visām pārējām konjugācijām, t.i., ar 3., 4. un 5. konjugāciju.

Locīšanas paraugs:

$\begin{array}{ll}\text { es } m \bar{a} k-u & m \bar{e} s m \bar{a} k \text {-am } \\ \text { tu } m \bar{a} k-i & j u \bar{s} m \bar{a} k \text {-at }\end{array}$

viňs, vini $m a \bar{k} k$

Pēc 2. konjugācijas parauga loka:

1) verbus, kuri infinitīvā beidzas ar $-\bar{e} t$, proti, to nenoteiksme darinăta ar piedēkli $-\bar{e}-$, un kuru pamatforma

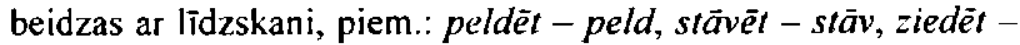
zied, gribēt - grib, dzirdèt - dzird, skanēt - skan, cerēet - cer,

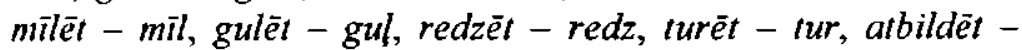
atbild, derēt-der, drikstēt -drikst u.c.

Paralēli formām: es sēž-u, tu sēed-i, viņš, vini sēez, mēs $s \bar{e} \check{z}$-am, jūs sēż-at, kas tiek atzītas par literāro normu, samērā bieži kā sarunvalodā, tā rakstos darbības vārds sēdèt tagadnē

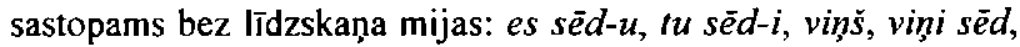
$m \bar{e} s$ sèd-am, jūs sēd-at. Sal., piem.: Un tā nu abi joprojām $s \bar{e} \check{z}$ viens otram pretim.. Ezera Cilv. 54; ..mamma man blakus $s \bar{e} d$ klusi, klusi.. Ezera Vasara 86. Daži rakstnieki formas sēžlsēd lieto pamīšus vai dzejā izmanto pēc vajadzības atskaṇu veidošanai, piemēram, Rudens $s \tilde{e} z \check{z}$ starp raibām teltīm .. kā $s$

${ }^{5}$ Sk.: Latviešu valodas vārdnīca. - R., 1987. - 706. Ipp 
$\bar{e} d$ vinam cepure galvā Bet es $s \bar{e} d u, s \bar{e} d u$. Čaks Padegs 21, 23, 117. S é žz u te jau sesto dienu. (.) Pie tūkstoš stropiem tūkstoš lāću $s \bar{e} d \quad$ Pie tūkstoš galdiem tūkstoś laužu èd.. Zied. Kā svece 62, 126; .. kad abi jūs s é ž a t pie vasaras malas! (..) Bet toties mès $s \bar{e} d a m$ ne kaut kur tur malā. Vāc. Gamma 92, 125.

Verba vajadzēt, nevajadzēt - vajag, nevajag, kas lokāms pēc 2. konjugācijas parauga, vienīgajai, t.i., 3. personas formai iespējams variants vajaga, nevajaga, piem.: Man jūs n e v a j a g a ne viena, ne otra. Dzil. Sapl. 19. Man ne vajag a nekā no tā.. Zied. Kā svece 143. Man n e vajag, mìlulīt, ko jūt caur riepām! Man v a ja g, ko jūt caur kājām. Vāc. Gamma 26. Man vajag a kustību, biezumu, vidu, man v aj a g pieskārienus. M.Kroma Stāvā 30.

2) darbības vārdus, kuri 3. personā (pamatformā) beidzas ar piedēkli -st, piem.: grimt - grimst, slāpt - slāpst, salt - salst, lüzt - lüst, klìst - klīst, kaist - kaist, kalst - kalst, plīst - plisst, plaukt-plaukst, lìt - lisst, klüt - klūst, pūt - püst, pazìt - pazist, atzìt - atzīst, rimt - rimst, mirt - mirst, $\dot{g} \bar{l} b t-\dot{g} \bar{i} b s t, d \bar{l} g t-d \bar{l} g s t$, dzimt - dzimst, skumt - skumst, reibt - reibst, sarkt - sarkst;

3) šādus darbības vārdus, kam tagadnes celms beidzas ar līdzskani $-d,-p,-t$ : dziedāt -dzied, raudāt - raud, tapt - topi top, just - jüti - jüt, zust - zūdi - zūd, (at)rast - (at)rodi (at)rod, lipt - lippi - līp, drupt - (drūpi) - drūp, klupt - klüpi $k l u \bar{p}, m i s t-m \bar{u} t i-m \bar{u} t$, prast - proti - prot, krist - krīti - krīt.

Dažiem verbiem 3. personā, tâtad pamatformā, vērojamas paralēlformas - vai nu forma, kas beidzas ar saknes līdzskani, vai forma, kas beidzas ar piedēkla garo patskani $-\bar{e}$, piem.: bālēet - bäl/bālēe, balēt - bal/balēe, pelēt - pel/pelē. Līdz ar to šos verbus loka kā otrās vai attiecīgi kā 5.konjugācijas darbỉbas vārdus.

\section{Atgriezeniskie verbi}

Tagadnes 2. konjugācijas atgriezeniskajiem verbiem ir raksturīgs îsais patskanis - $a$ - 3. personas un daudzskait|a 1 . un 2 . personas galotnē. 


\section{Locīšanas paraugs:}

$\begin{array}{ll}\text { es peld-os } & \text { mēs peld-amies } \\ \text { tupeld-ies } & j \overline{u s} \text { peld-aties }\end{array}$

vinšs, viņi peld-as

Pēc 2. konjugācijas parauga loka, piemēram, refleksīvos verbus: pūlèties - pūlas, ieraudāties - ieraudas, sadziedāties sadziedas, precēties - precas, atcerēties - atceras, mazgāties mazgājas, doties dodas. Vairumam atgriezenisko verbu tagadnē piemīt 2. konjugācijas paradigma. Tie ir visi refleksīvie verbi, kuru pamatforma beidzas ar -as, un kuri nepieder pie 4. konjugācijas, piem.: priecāties - priecājas, smieties - smejas, justies - jūtas, kauties - kaujas, atpüsties - atpūšas, veseloties veselojas.

Atšķirībā no tiešajiem darbības vārdiem, kā jau iepriekš tika minèts, atgriezeniskajiem verbiem tagadnē ir tikai trīs locīšanas paveidi, tos loka pēc l., 2. vai 4. konjugācijas parauga.

\section{Tagadnes 3. konjugācija}

\section{Tiešie verbi}

Tagadnes 3. konjugācijai ir vienīgi sava atšḳirīga tiešo verbu personu paradigma, jo atbilstošie atgriezeniskie verbi tiek locīti pēc otrās konjugācijas parauga. Tiešo verbu tagadnes 3 . konjugācijas pazīme ir galotnes - $i$ zudums vienskait|a 2.personā. Šiem verbiem (tāpat kā 2.konjugācijas verbiem) nav arī 3. personas galotnes $-a$.

Locî̉anas paraugs:

es brauc-u, dod-u

tu brauc, dod mès brauc-am, dod-am

jūs brauc-at, dod-at

vinš, vini brauc, dod

Tagadnes 3. konjugācijas verbiem raksturīgs tas, ka gan to pamatforma (3. personas forma), gan vienskaitla 2. personas forma beidzas ar līdzskani. Turklāt šiem verbiem nenoteiksmē nav piedēkla. 
Pie tiešo verbu tagadnes 3. konjugācijas pieder, piemēram, šādi latviešu valodas darbïbas vārdi: nest - vinšs nẹs tu nes, mest - mett - met, sist - sit - sit, ëst - êd-èd, vest - vedved, pit - pin - pin, liet - lej - lej, rit - rij - rij, kopt - kopjkop, stumt - stumj - stum, sveikt - sveic - sveic, lügt - līdz lüdz, elst - elśs - els, berzt - berź - berz, smelt - smel - smel, ciest - cieš - ciet, laist - laiž - laid, siet - sien - sien, plaut plauj - plauj, nemt - ņem - nem, cirst - cềrt - cērt, šūt - šuj $\check{s} u j$, slēgt - slēedz -slèdz, kliegt $-k l i e d z-k l i e d z$.

\section{Tagadnes 4. Konjugācija}

\section{Tiešie verbi}

Tiešo verbu tagadnes 4 . konjugācijai raksturīgs tas, ka atšķirībā no tagadnes pamatcelma vienskait|a 2. personā notiek līdzskaṇu $k$-c un $g-d z$ mija. Personu galotṇu ziṇā šī konjugācija sakrīt ar 3. konjugāciju un var tikt uzskatīta par tās paveidu.

Locīšanas paraugs:

es velk-u, bēg-u

tu velc, be dz mēs vẹlk-am, bēg-am

jüs vẹlk-at, bēg-at

viņš, viņi vẹlk, bejg

Pēc šā parauga loka, piemēram, darbības vārdus: rakt vin̄s, viņi rok - tu roc, sākt - sāk - sāc, näkt - nāk - nāc, liktliek - liec, smakt - smok - smoc, patikt - patik - patīc, mukt $m \bar{u} k-m \bar{u} c, t i k t-t i e k-t i e c$, apjukt - apjūk - apjūc; augt - viņš, vini aug - tu audz, aizmigt - aizmieg - aizmiedz, iedegt - iedeg iededz.

\section{Atgriezeniskie verbi}

Tāpat kā tiešo, arī atgriezenisko verbu tagadnes 4 . konjugācijas pazīme ir saknes līdzskaṇu $k-c, g-d z$ mija vienskait|a 2. personā. Pēc personu galotnēm š̀ konjugācija ir 
identa atgriezenisko verbu tagadnes 2 . konjugācijai un var tikt atzìta par tās paveidu.

Locīšanas paraugs:

es satiek-os, iedeg-os tu satiec-ies, iededz-ies mēs satiek-amies, iedeg-amies

jūs satiek-aties, iedeg-aties

vinš, vini satiek-as, iedeg-as

Pēc šã parauga loka, piemēram, šādus refleksīvos verbus: (aiz)rakties - viňs, vini (aiz)rokas tu (aiz)roc-ies, vilkties velk-as - velc-ies, izlikties izliek-as izliec-ies, paaugties - paaugas - paaudzies.

\section{Tagadnes 5. konjugācija}

\section{Tiešie verbi}

Sava īpaša 5 . konjugācijas personu formu paradigma ir vienīgi tiešajiem verbiem; tiem atbilstošie atgriezeniskie verbi tiek locīti pēc otrās konjugācijas parauga. Tiešo verbu 5 . konjugācijai tagadnē ir raksturīgi tas, ka 3. personas un vienskait]a 2. personas formas ir vienādas un beidzas ar garo piedēkla patskani vai divskani $-o$. Taču šo verbu pilns tagadnes celms beidzas ar piedēkli $-j-$, tāpēe, lai iegūtu pamatcelmu, 3 . personas formu nepieciešams papildināt ar zudušo $-j$-.

Locīšanas paraugs:

$\begin{array}{ll}\text { es domāj-u } & m \bar{e} s \text { domăj-am } \\ \text { tu domāa } & j \bar{u} s \text { domāj-at }\end{array}$

viňš, viņi domã

Pie 5. konjugācijas pieder darbỉbas vārdi, kuru tagadnes 3. personas forma beidzas

1) ar - $\bar{a}$ un pamatcelms attiecīgi ar -ōj, piem.: runāt runā - runāj, glabāt - glabā-glabāj, maksāa - maksāa-maksāj, strādāt - strādā - strādāj;

2) ar $-\bar{e}$ un pamatcelms attiecīgi ar $-\bar{e} j$, piem.: $t \bar{e} r \bar{e} t-t \bar{e} r \bar{e}$

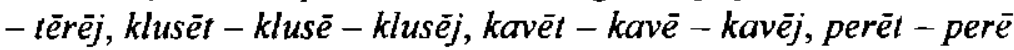
- perēj, braukalèt-braukalè-braukalēj; 
3) ar -i un pamatcelms attiecīgi ar - $\bar{\imath}$, piem.: svētīt $-s v \bar{e} t \bar{t}$ -svētīj, kristīt - kristī-kristijj, apbedīt - apbedi - apbedij, zeltīt

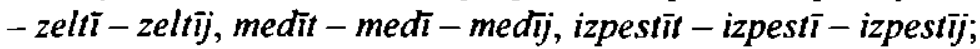

4) ar -o un pamatcelms attiecīgi ar -oj, piem.: šūpot šūpo - šūpoj, bēgulot - bēgulo - béguloj, vakarinot - vakarino vakarinoj, elpot - elpo - elpoj, balsot - balso - balsoj;

5) ar $-\bar{u}$ un pamatcelms attiecīgi ar $-\bar{u} j$ : dabūt $-d a b \bar{u}-$ $d a b \bar{u} j$.

Piemēram, Mãcītājam vai baznīcai $z$ i e do licīgie arī la alajoties, kristijot bèrnus, a p bedijot tuvinjekus vai aizlüdzot par mirušo dvēselēm, pat $s$ vēt i jot dzĩvokJus un automašinas. NRA 1997.g. 8.nov., 5.

\section{Nekārtno verbu tagadnes konjugäcija}

Savdabīgi jeb nekārtni lokāmi tagadnē ir latviešu valodas verbi būt, iet un atvasinājumi no tiem, piem., nebūt, aiziet, atiet, paiet, pāriet, pieiet, saiet, uziet, apieties, saieties, paieties.

\section{Tiešo nekārtno verbu konjugācija}

Tiešo nekārtno verbu locî̌sana tagadnē no citiem latviešu valodas darbỉbas vārdiem atšksiras ar atsevišķu citsaknes jeb supletīvu formu izmantošanu un īpatnējām t.s. atematiskajām galotnēm - $m u$ (vienskait|a 1.personāa) un $-t$ (3.personā). ${ }^{6}$

Locīšanas paraugs:

es es-mu, nees-mu, ej-u mēs es-am, nees-am, ej-am tu es-i, nees-i, ej jūs es-at, nees-at, ej-at viñs, vini ir, nav, ie-t

Paralēli nav, ko parasti min normatīvajās gramatikās ${ }^{7}, k \bar{a}$ mutvārdos, tā rakstos dažkārt sastopama forma nava, piem.:

${ }^{6}$ Sk., piemēram, Endzelīns J. Latviešu valodas gramatika. - R., 1951. 708. lpp.

${ }^{7}$ Mūsdienu latviešu literārās valodas gramatika, I. - R., 1959. - 682. Ipp. 
Milam Dievam kiosku vēl $n$ a v a.. Čaks K.r. 79; ..cita cela $n$ a v a.. Grīns Dvēs. 68. Nez käpēc pasaulē n a v a vēl kādas miglas.. Vāc. Gamma 88.

\section{Atgriezenisko nekārtno verbu konjugācija}

Refleksīvus verbus, kuri darināti no būt, latviešu literārajā valodā nemēdz lietot. Līdz ar to atšksirības locǐsanā, turklāt vienīgi 3.personā, tagadnē piemīt atgriezeniskajiem verbiem, kuri darināti no iet, piem.: saieties, paieties, apieties.

Locīsanas paraugs
es apej-os
tu apej-ies
viņs, vini apie-tas
mēs apej-amies
jüs apej-aties

\section{Pagātnes konjugācija}

Atškirỉbā no tagadnes formām darbibas vārdu locīšanai pagātn̄e raksturīga regularitāte. Veidojot pagātnes formas, pagātnes celmā nenotiek nekādas pārmaiņas, turklāt tiek izmantota vienota personas formu galotnu sistēma. Protams, atšķirīgas ir tiešo un atgriezenisko verbu personu galotnes. Līdz ar to pagātnē pastāv tikai divi konjugācijas paveidi: tiešo un refleksīvo darbỉbas vārdu paradigma.

\section{Locīšanas paraugs:}

es èd-u, runāj-u, klausīj-os mēs èd-ām, runāj-ām, klausīj-āmies tu $\bar{e} d-i$, runāj-i, klausijj-ies $j \bar{u} s \bar{e} d-\bar{a} t$, runāj-āt, klausīj-āties

$$
\text { vinš, viṇi êd-a, runāj-a, klausīj-ās }
$$

Regulāri pagātnē tiek konjugēti nekārtnie darbības vārdi $b \bar{u} t$, iet un atvasinājumi no tiem. Vienīgi paralēli pilnajai formai bija diezgan bieži sastopama bezgalotnes 3.personas forma $b i j$, sal., piemēram, Bet ne tikvien lopu pulks b ij a vingas zināšanã un gādībā. Virza Straum. 115. Tā $b$ i j jauna lampa ar desmitliniju dakti.. A.Upīts Z. z. 407.

Dažādu autoru darbos ir atšķirīgs formu bija un $b i j$ sadalījums. Abas šīs formas bija/bij lieto, piemēram, A.Čaks, 
Ludis Bērziṇs̆: B ij acis vingam pēc krāsas kā kakim.. İss b ij a vinu müžs.. Čaks K. r. 13, 100. Tēvs un māte nekādas skolas n e b i j a apmeklējuši.. Lïdz skolas vecumam nu bij vēl gaidāmi daži gadi. Pašp. (L.Bērziņš) 32. Galvenokārt pilno formu bija izmanto J.Veselis. Savukārt Aīda Niedra vairāk iecienījusi īsāko $b i j$. Izdevniecību praksē reizêm tiek vispārināta garākā forma bija.

\section{Nākotnes konjugāija}

Tāpat kā pagātnes konjugācijai, arī latviešu valodas darbības vārdu locīšanai nākotnē piemīt regularitāte. Vispārējā nākotnes formu veidošanas shēmā no nenoteiksmes celma iek|aujas nekārtnie verbi, un kopumā var runāt par diviem konjugācijas pamattipiem, proti, tiešo un atgriezenisko verbu nākotnes paradigmu.

Locīšanas paraugs:

es bū-š-u, runā-š-u, klausī-š-os mēs bū-s-im, runā-s-im,

klausī-s-imies

tu bū-s-i, runā-s-i, klausī-s-ies jī̄s bū-s-it (-iet), runā-s-it (-iet), klausi-s-ities (-ieties)

vin̄s, vini bū-s, runā-s, klausi-s-ies

Divi varianti pastāv nākotnes celmu pašu kā tādu veidošanā gadījumos, kad darbības vārda celms nenoteiksmē beidzas ar līdzskaṇiem $s, z$, bet pagātnē $-s, z$ vai $t, d$ :

1) nākotnes celma pagarinājums, tajā papildus iespraužot piedēkli - $\overline{-}-$, piem.: nes-t, nes-a - nes- $\bar{l}-\bar{s}-u$, lauz-t,

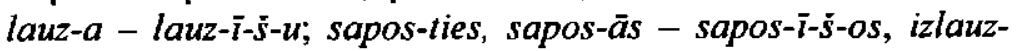
ties, izlauz-ās - izlauz- $\bar{i}-\check{s}-o s$;

2) kombinēts paveids ar līdzskaṇu miju un celma pagarinājumu nākotnē, sal., piem.: sis-t, sit-a, - sit-i-š- $u$, ves-t,

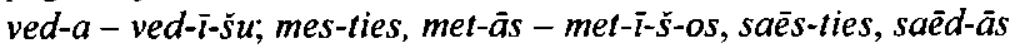
- saēd-i-śs-os. 


\section{Saīsinājumi}

A.Egl. Lugas -Eglītis A. Lugas. - R., 1990.

A.Upīts Z. z. - Upīts A. Zajā zeme. - R., 1947.

Čaks K. r. - Čaks A. Kopoti raksti. - 1. sēj. - R., 1991.

Čaks Padegs - Caks, Padegs. Rīga. 30.gadi. - R., 1985.

Dzil. Sapl. $\quad$ - Dzilums A. Saplēstā krūze. - R., 1990.

Ezera Cilv. - Ezera R. Cilvēkam vajag suni. - R., 1975.

Ezera Vasara - Ezera R. Vasara bija tikai vienu dienu. - R., 1974.

Grīns Dvēs. - Grīns A. Dvēselu putenis. - R., 1989.

M.Kroma Stāvā - Kroma M. Stāvā jūrā. - R., 1982.

NRA - "Neatkarīgā Rìta Avīze"

Pašp. $\quad-$ Pašportreti. Autori stāsta par sevi. Sakārt. un red. T.Zeltiṇš. N̦ujorka: Grāmatu draugs, 1965.

Vāc. Gamma - Vācietis O. Gamma. - R., 1991.

Virza Straum. - Virza E. Straumēni. - R., 1989.

Zied. Kā svece - Ziedonis I. Kā svece deg. - R., 1971.

\section{GRUNDFORMEN UND KONJUGATION DER LETTISCHEN VERBEN \\ Zusammenfassung}

Es handelt sich um einen Vorschlag in Bezug auf die Morphologie der lettischen Verben: die dritte Person wird als Grundform der Konjugation von Verben betrachtet, und es wird ein neues Herangehen zur Konjugation des Verbs im Präsens vorgeschlagen. 


\section{Andra KALNAČA}

\section{VERBA DARĀMĀS UN CIEŠAMĀS KĀRTAS SINONĪMIJA}

Verba kārta ir morfologiski sintaktiska kategorija, kas verba struktūrā izpaužas $\mathbf{k} \overrightarrow{\mathbf{a}}$ spēja izteikt sakarus starp darbības subjektu, darbību un darbības objektu. Kārtas kategorijas pamatā latviešu valodā ir divas semantisko opozīciju grupas:

a) verba pārejamības / nepārejamỉbas opozīcija, kuras izpausme ir sintaktiska;

b) tiešo / atgriezenisko verbu opozīcija, kuras izpausme ir morfoloǵiska'

Verba darāmās / ciešamās kārtas opozīcija iespējama tikai tiešiem pārejošiem verbiem - tātad semantiski, morfologiski un sintaktiski ierobežotai verbu grupai.

Verba kārtu opozīcija ir privatīva:

\section{Darāmā kărta}

(-)

Opozīcijas nemarkētais loceklis, jo izsaka ar istenības izteiksmes laika formām, kurām nav īpaša morfolog̀iskā kārtas formanta

\section{Ciešamā kãrta}

(t)

Opozīcijas markētais loceklis, 1) morfolog̣iskãa marḳêtājpazìme ir verba ciešamās kārtas forma palīgdarbỉbas vārdi $t i k t, b \bar{u} t$ kopā ar lokāmo pagātnes pasīvo divdabi - tiek darīts, bija celts;

2) sintaktiskā marḳētājpazīme ir teikuma struktūras maiṇa uz darbības subjekta elidāciju

Celmieki $\left(\mathrm{S}^{2}\right)$ cel namu $\left(\mathrm{O}_{\mathrm{A}}\right) . \quad \operatorname{Nams}\left(\mathrm{O}_{\mathrm{N}}\right)$ tiek celts.

${ }^{1}$ Mūsdienu latviešu literārās valodas gramatika.I. - R. 1959, 547-548.

2 Šeit un turpmāk: S - subjekts, O - objekts, A - akuzatīvs, D - datīvs, $\mathrm{N}$ - nominatīvs. 
Privatīvajās opozīcijās gramatikā nereti ir vērojams, ka nemarkētie opozīcijas locek/i spēj uzñenties markēto locekju semantiskās un gramatiskās funkcijas. Tātad veidojas konteksta nosacīta gramatiskā sinonīmija. Tā latviešu valodā iespējama verba kārtu sinonīmija. Kārtu sinonīmija nav tik plaša un sazarota kā, piemēram, laika vai izteiksmju formu sinonīmija, jo par kārtas kategoriju, kā jau minēts, var runāt tikai tiešajiem pārejošajiem verbiem.

Rakstā tuvāk tiks analizēti trīs gadījumi, kuri būtu uzskatāmi par verba kārtu sinonīmiju jeb verba darāmās un ciešamăs kārtas opozīcijas neitralizāciju.

Prozā vēstījuma tekstos var konstatēt teikumus darāmajā kārtā ar tiešu, pārejošu verbu, tomēr teikumam nepārprotami ir ciešamās kārtas nozīme Galdinšs vai lūza no milzīga greznu grāmatu blāka. Tur redzẽja visus jaunākos, dārgākos izdevumus (A.Eglītis Homo..); Lielajai sienas freskai trüka galvenās personas, pašas Galatejas. Tās vietā freskā redzēja tikai blāvu laukumu (J.Sarma); Gediminu un Andu jau sen uzlükoja par nodibinājušos pāri (A.Eglītis Cilvēks.); Par vinu [F. Dostojevski] ir rakstītas monogrāfijas, un arī nākotnē tādas rakstis (I.Mellis).

Ciešamās kārtas nozīme šādos teikumos ir konteksta nosacīta nav minēts darbïbas veicējs, un izteicējam nav nosakāma konkrētas personas forma. Verbiem redzēja, uzlükoja, rakstīs ir 3. personas forma, bet skaitli konteksts nerāda, kas nav raksturīgi teikumos darāmajā kārtā. Darbības subjekta elidācijai un verba skait|a neitralizācijai ir semantisks mērḳis - norādīt uz darbības vispārinājumu vai nekonkrētību ${ }^{3} T \bar{a}$ rezultātā finītā verba forma kontekstā it kā iegūst infinītas, ar konkrētu personu nesaistītas verba formas izpausmi. Tas arī būtu uzlūkojams par pamatu verba darămās un ciešamās kārtas sinonīmijai minētajos teikumos. Nereti teikumus darāmajā kārtā bez darbības subjekta

A.Holvuts šãdus teikumus uzskata par īpašām nenoteiktas personas konstrukcijām skat. Holvuts A. Latviešu valodas pasīvās un nenoteiktas personas konstrukcijas no areāltipolog̣ijas viedokla // Linguistica Lettica. - R., 1997, 117-128. 
var konstatêt visai plašos teksta fragmentos, kur tiek izklāstītas kādas atminas par senākiem laikiem vai notikumiem. Tā tiek panākts loti vispārināts un iespējami objektīvs kāda laikmeta vai notikuma dokumentējums. Šāds tekstveides pañēmiens atrodams Z.Skujiṇa, A.Eglīša u.c. rakstnieku darbos. Piemēram, ievads noda|ai "Pēckara ainiṇas" Z.Skujiṇa grāmatā "Jātnieks uz lodes", kur autors atceras laiku pēc Il Pasaules kara:

Karalaika uzspiestā nabadzība, vairākkārt lāpūtās un pāršūtās drēbes, ieilgušais sastingums bija līdz kaklam apnicis. Sirds tā vien tīkoja panākt nokavēto, griezt no svaiga baka..

No svaiga baķa patiešām nebija griezts sen. Mètelus šsua no gultas segām, kleitās pārbūra drapērijas.. Sieviešu blüzēm un vīriešu krekliem bieži lietoja izpletṇu zīdu. Uzvalkos gandrīz neviens nestaigäja. Kaklasaites pa kara gadiem bija piemirsušās. Virskreklam pāri uzvilka dżemperi, krekla stūrī̌sus izņemot virs adītās apkakles (Z.Skujin̄š).

Analizējot šo teksta fragmentu, redzams, ka darāmās kārtas verbu šuva, pārbüra,lietoja, uzvilka vietā varētu būt arī ciešamās kārtas formas, nemainoties saturam - tika šüti, tika pārburtas, tika lietotas, tika uzvilkti. Tomēr darāmās kārtas formas ar nekonkrētu personas un skait|a formu piešķir lielāku vispārinājuma nokrāsu nekā sinonīmiskās ciešamās kārtas formas ar noteiktu personu un skaitli ${ }^{4}$

Pārveidojot iepriekšminētos darāmās kārtas teikumus ciešamajā kārtā, vērojams, ka ne vienmēr iespējamas paradigmātiskās ciešamās kārtas formas; piemēros verbiem uzlūkot, rakstīt - Gedimīns un Anda tika uzlükoti par pāri; monogräfijas tiks rakstītas. Ja ciešamajā kārtā transformē teikumus ar verbu redzēt, sinonīmiskās formas ir citas - jaunākie izdevumi bija redzami, blōvs laukums bija redzams. Tagadnes

4 Tātad verba kārtas formu sinonīmija var būt viens no būtiskiem elementiem darbības vispārinājuma izteikšanā. Protams, svarīga ir arī pārējo teikuma locekłu forma un semantika. Par to tuvāk skat. Kalnača A. Darbības vārda laika formu funkcionālā sistēma latviešu valodā. Disertācija filolog̉ijas doktora grāda iegū̌sanai, - R., 1996, 75 97. 
pasīvais divdabis latviešu valodā neietilpst verba ciešamās kārtas formu paradigmā, lai arī tam piemīt izteikta ciešamās kārtas nozīme.

Arī refleksīvajiem verbiem noteiktā kontekstā var būt ciešamās kārtas nozīme, piemēram, Divas dienas, kamēr $\underline{s u}$ ūūs svārki, Upenājs neatstāja darbnīcu (A.Eglītis Homo..); Pirmo reizi piezvanot, durvis neatvērās (A.Eglītis Cilvēks..); neliterārs lietojums Veikals atvērsies pēc mēneša; Veikals ir pārcēlies uz citām telpām; Otrā krastā redzèjās nami, nami un atkal nami (M.Stāraste); Śajā Veršinininā [tēls A.Čehova lugas "Trīs māsas" iestudējumā] loti skaidri "nolasījās" doma, ka visas idejas par brīnumaino nākotni ir "bleķis" (Diena) utt. Šādu darāmās un ciešamās kārtas formu sinonīmiju parasti skaidro ar krievu valodas ietekmētu nepareizu refleksīvo verbu lietojumu ciešamās kārtas nozīme $\bar{e}^{s}$ Tiek ieteikts šos refleksīvos verbus aizstāt ar ciešamās kārtas formām ${ }^{6}$ Tomēr, pārveidojot nepareizās refleksīvās formas ciešamajā kārtā, ne vienmēr iespējama paradigmātiskā ciešamās kārtas forma - svārki ̌̌suās $\Rightarrow$ svārki tika šūti;durvis neatvērās $\Rightarrow$ durvis netika atvērtas; veikals atvērsies $\Rightarrow$ veikals tiks atvērts; veikals ir pārcēlies $\Rightarrow$ veikals ir pärcelts utt. Bet nami redzējās $\Rightarrow$ nami bija redzami; doma nolasijās $\Rightarrow$ doma bija nolasāma utt.

Kādi varētu būt šādas gramatiskās sinonīmijas cēloṇi, vai tikai un vienīgi krievu valodas ietekme? Jāsaka, ka šajā gadījumā ir grūti precīzi norobežot gramatiskās sinonīmijas cēloṇus latviešu valodā un iespējamo citas valodas ietekmi. Var

${ }^{5}$ Krievu valodā ciešamo kārtu izsaka ar refleksīvajiem verbiem. Tomēr arī krievu valodā ciešamās kārtas nozīme dalai verbu ir saistīta ar kontekstu - vienam un tam pašam verbam atkarībā no konteksta var būt darāmās un ciešamās kārtas nozīme, piemēram, наниматься, удаляться u.c.; skat. Храковский В.С. Грамматические категории глагола (опьт теории взаимодействия) // Межкатегориальные связи в грамматике. Санкт - Петербург, 1996, 34.

${ }^{6}$ Skat. Freimane I. Valodas kultūra teorētiskā skatījumā. - R.,1993, 207 - 208; kā arī Endzelīns J. Dažādas valodas klūdas // Darbu izlase $\mathrm{III}_{2}$. R., 1980, 42 u.c. 
minēt vismaz trīs faktorus, kas latviešu valodā veicina refleksīvo verbu lietojumu ciešamās kārtas nozīmē.

Pirmkārt, visiem refleksīvajiem verbiem, kas lietoti pasīva nozīmēe, pamatā ir pārejošs verbs (piemēros šūties - šūut, atvērties - atvērt, redzēties - redzèt, nolasities - nolasīt utt.). Kā norāda R. Veidemane', refleksīvo galotni par intransitivitātes rādītāju var atzīt tikai nosacīti, jo latviešu valodā ir gan konkrētas, gan abstraktas nozīmes atgriezeniski verbi, kas ir pārejoši iegādāties apgèerbu, noskatīties filmu, atcerēties dzejoli. mācīties uzdoto u.c. Liela daja refleksīvo verbu pārejamỉbu jeb spēju piesaistīt objektu akuzatīvā ir saglabājusi no tiešā verba, vārddarināšanas procesā šai nozīmei nezūdot.

Otrkārt, teikumos svārki šinās, veikals atvērsies, būdinas redzējās, doma nolasījās teikuma locek|us nominatīvā nevar uzskatīt par darbības subjektiem, tie ir darbības objekti. Arī leksiskās nozīmes ziñā vārdi svārki, veikals, būdinas u.c. ir pasīva nojēguma izteicēji - nedzīvi priekšmeti, kas paši nekādu darbỉbu veikt nevar (izṇēmums - personifikācija) ${ }^{8}$ Var teikt, ka teikumos, kur refleksīvais verbs ir pasīvā nozīmē, ir tā pati sintaktiskā konstrukcija, kas teikumos ar verbu ciešamās kārtas formā:

Darāmā kārta Drēbnieks $\left(S_{N}\right)$ šuva svārkus $\left(O_{\mathcal{A}}\right)$.

Ciešamā kārta Svārki $\left(O_{N}\right)$ tika šüti; Svārki $\left(O_{N}\right)$ šuvās.

Treškārt, latviešu valodā neskaidrs ir atgriezenisko verbu kārtas statuss - tā ir vidējā vai darāmā kārta. Pašlaik latviešu valodniecībā dominē uzskats, ka refleksīvo verbu galotnes

"Veidemane R. Morfēmas -ies vieta latviešu valodas verbu sistēmā // Veltījums akadēmiķim J.Endzelīnam (1873 - 1973). - R., 1972, 440.

8 "Mūsdienu latviešu literārās valodas gramatikă" refleksīvo verbu nozīmju apskatā (560.lpp.) teikts, ka "ar verbu refleksīvajā formā retumis izsaka darbỉbu ar p a s i v u nozĩmi, piemēram, nauda $g$ l $a$ b āj a s [tiek glabōta] bankā, aparāts nol i e toj a s [tiek nolietots].. Šîs formas uztveramas arī kā norise bez subjekta aktivitātes." 
galvenokārt ir leksiskas nozīmes rādītājas un funkcionē kā vārddarināšanas morfēmas ${ }^{9}$ Tātad atgriezeniskie verbi būtu ietilpināmi darāmajā kārtā. Tomēr latviešu valodā ir verbu grupa, kas vidējās kārtas nozīmi ir saglabājuši, vienā formã apvienojot darbības subjekta un objekta nozīmi, piemēram, mazgāties, gèerbties, samierināties, skoloties, pärkrustīties u.c. Šo verbu grupu mediālās nozīmes dē| darbïbas vārda kārtas analīzē nevar ignorēt un iek|aut darāmajā kārtā ${ }^{10}$ Trīslocek|u kărtas opozīcijai darāmā kārta - vidējā kārta - ciešamă kārta latviešu valodā veidojoties par bināru opozīciju darāmā kārta ciešamã kārta, vidējā kārta tomēr īsti nav iek’̣āvusies ne darāmajā, ne ciešamajā kārtā, un atgriezeniskie verbi funkcionāli spēj izteikt triju kārtu nozīmes. Tādēl krievu valodai raksturīgais refleksīvo verbu lietojums pasīvā nozīmē spējis jūtami ietekmēt atgriezenisko darbības vārdu lietojumu latviešu valodā, veicinot neliterāru kārtas formu gramatisko sinonīmiju.

Verba kārtas kategorijas problēmu analīzē svarīgs ir arī J. Endzelīna atzinums, ka "baltu valodām pasīva izteiksme laikam ir radusies tikai jaunākā laikā un citu valodu ietekmể”" Uz to norāda arī atšḳirīgās ciešamās kārtas paradigmas latviešu un lietuviešu valodā. Lietuviešu valodā ciešamās kārtas paradigmā ir ieklauti abi pasīvie divdabji tagadnes pasīvais divdabis ar piedēkli -am-/-äm- un pagātnes pasīvais divdabis ar piedēkli - $t_{-}^{12}$ piemēram, šita prekè yra parduodama 'šī prece tiek pārdota' - ciešamās kārtas vienkāršā tagadne; šita preké yra

${ }^{9}$ Soida E. Refleksīvais verbs latviešu valodas vārddarināSanas sistēmā // Hrestomātija mūsdienu latviešu literārās valodas vārddarināšanā. - R., 1991, 33-37; Veidemane R. Morfēmas -ies vieta latviešu valodas verbu sistēmā, 427-442.

${ }^{10}$ Turklāt atgriezeniskajiem verbiem ir loti daudzveidīga semantika, kas daudzos gadījumos ir sajstāma ar vidējās kārtas nozīmi skat. "Mūsdienu latviešu literārās valodas gramatiku" 556 561, arī Veidemane R. Morfēmas -ies vieta latviešu valodas verbu sistēmā u.c.

${ }^{11}$ Endzelīns J. Baltu valodu skanas un formas // Darbu izlase $\mathrm{IV}_{2}$. R., 1982, 585.

12 Paulauskienè A. Lietuviu kalbos morfologija. Vilnius, 1994, 351 356 un $364-365$. 
parduota 'šī prece ir pārdota' - ciešamās kārtas saliktā tagadne. Latviešu valodā verba ciešamās kārtas paradigmā ietilpst tikai pagātnes pasīvais divdabis. Tomēr darbības vārda darāmās un ciešamās kārtas sinonīmijas analīzē vērojams interesants fakts $k a \bar{c}$ ciešamās kārtas forma darbojas arī tagadnes pasīvais divdabis ar piedēkli -am-/ -ām- predikatīvā funkcijā. Taču latviešu valodā šim divdabim ir lielāka modālā slodze. Tagadnes pasīvais divdabis predikatīvā funkcijā var izteikt vajadzības nozīmi un iespējama šāda teikuma transformācija:

Darămā kārta, isstenības izteiksme Es $\left(S_{N}\right)$ rakstu vēstuli $\left(O_{A}\right)$.

Darāmā kārta, vajadzības izteiksme $\operatorname{Man}\left(S_{l}\right)$ ir järaksta vēstule $\left(O_{N}\right)$.

Ciešamā kärta Vēstule $\left(O_{N}\right)$ ir rakstāma. ${ }^{13}$

Līdzīgi transformējami ir arī teikumi Śs intermeco nu bija aizmirstams (=bija jāaizmirst) (Z.Skujiņš); Atkārtoti vinš mani pamācīja, kā ratini stumjami (=ir jāstumj), kā celami (=ir jācel) no ielas uz ietvi (I.Mellis); Turneja bija tà izplānota, ka nākamā lekciju vieta sasniedzama (=bija sasniedzama) apmēram trīs stundās (I.Mellis) u.c.

Šādos gadījumos darāmās un ciešamās kārtas sinonīmija ir saistāma ar vajadzības izteiksmi. Tas jauj secināt, ka kārtas un modalitātes nozīmes latviešu valodas verba formu sistēmā ir mijiedarbībā.

\section{AVOTI}

Diena (laikraksts)

Eglītis A. Cilvēks no Mēness. - R., 1994.

Eglîtis A. Homo Novus. - R.,1992.

Mellis I. Trīsdesmit divi gadi kopā ar Zentu Mauriņu. - R.,1997. Sarma J. Gadsimteņi. - R.,1959.

${ }^{13} \mathrm{~V}$ Bērziña-Baltina tādus gadījumus uzskata par formām vajadzỉbas izteikšanai; skat. Bērziṇa - Baltiņa V. Latviešu valodas gramatika. R., 109. 
Skujiṇš Z. Jātnieks uz lodes. - R., 1996.

Stāraste M. Ej pie rūḳa skoloties! - R., 1993.

\section{SYNONYMY OF ACTIVE AND PASSIVE VOICE IN LATVIAN}

\section{Summary}

The system of verb is very complicated in Latvian. It includes a lot of different grammatical categories - tense, mood, voice, transitivity, reflexivity, etc. These categories are closely related to each other. The primary aim of this paper is the analysis of voice category. Causes of synonymy of voice forms, in Latvian are also dealt with.

The opposition of active and passive voice is possible only for non-reflexive, transitive verbs, which is a semantically, morphologically and syntactically limited group. Usage of verbs in different contexts shows synonymy of voices in some cases. This synonymy is not so rich as synonymy of tense or mood forms in Latvian.

One case is closely linked with informational text of fiction. There is a number of sentences in active voice with nonreflexive, transitive predicate. But these sentences clearly have the meaning of passive voice. Passive meaning is determined by context - there is no subject of action and the predicate does not have a concrete form of person and number. The aim of elidation of subject and neutralization of number is semantic it expresses generalization of action.

Another case of synonymy of voices is connected with reflexive verbs. Historically reflexive verbs expressing neuter voice consists of three members - active voice - neuter voice passive voice. This oposition develops into binar opposition in modern Latvian - active voice - passive voice. Reflexive verbs due to their spécific lexical and voice meaning functionally can express meanings of three voices in Latvian, and synonymy of voices is possible. 


\section{Juris GRIGORJEVS \\ LATVIEŠU VALODAS PATSKAN̦U AKUSTISKO IDEĀLFORMU NOTEIKŠANA}

Vèrojot fonologiskās domas attīstību dažādu valodu skaṇu inventāru aprakstî̌anā un to savstarpējo kopsakarîbu meklēšanā, var saskatīt tieksmi pēc ekonomiska, bet reizē izsmejoša apraksta veida. Tâ rezultăts ir fonēmu un fonēmu pārmainu teorija, kas lauj sadalīt jebkuras valodas skanisko inventāru nelielā fonēmu sistēmā, kur katras fonēmas konkrētā realizācija paḳaujas noteiktu fonolog̣isku likumu prasībām. Lìdz ar to, aprakstot fonēmu ipašs̆bas, tiek aprakstîtas šo valodā nozīmīgo skaņu ideālformas un to iespējamās izmaiñas katrā valodā funkcionējošu fonologisko likumu ietekmē. Ilgu laiku fonēmu aprakstā dominēja artikulārās ṣ̌īiējpazīmes, jo tās saistitas ar vieglāk novērojamiem artikulācijas procesiem. Jaunākās fonologiskās teorijās (Ladefoged 1989 u.c.) apraksts papildinăts arī ar auditīiām šḳīējpazīmēm, kas liek domāt par ideālformu kompleksu uzbūvi. Lai gūtu pilnīgāku priekšstatu par katrai fonēmai atbilstošă skannas prototipa jeb ideālformas īpašībām, ir veikts daudz nopietnu pètijumu. No tiem izriet, ka katras valodas skaņu sistēmas izveide ir paklauta universāliem nosacijumiem (Lindblom 1963, 1984):

1) cilvēka runas orgānu kustību amplitūda un ātrums ir samērā ierobežoti tas ierobežo teorētiski izrunājamo skaṇu daudzumu;

2) dzirdes uztveres īpatnību un artikulācijas polimorfisma dē| akustiski un auditĩvi vienādas vai loti tuvas (nebūtiski atšķirīgas) skaṇas var tikt izrunātas ar vairākiem atšḳirīgiem runas orgānu stāvok|iem;

3) valodas skaniskā inventāra izveidē dominē tieksme panākt tā locek]u maksimālu noškiritîbu ar minimālu enerǵijas patēriṇu.

Atbilstoši šiem nosacijumiem veidojies katras valodas skaniskais inventārs. Tieksme ekonomēt energiju nosaka to, ka no vairākiem vienādu skanisko signālu veidojošiem artikulatoru stāvok|iem tiek izvēlēts tas, kura veidošana prasa mazāko piepūli. Ja 
kādas slimības, traumas vai citu škēerṣ̌u dē| šis artikulatoru stāvoklis vairs nav iespējams, tas tiek aizstāts ar tuvāko iespējamo, kura rezultātā tiek iegūta analoga vai maksimāli tuva skaņa. Šo procesu sauc par artikulāro kompensāciju. Minēšu dažus no daudzajiem artikulārās kompensācijas piemēriem:

1) pēc lūzuma fiksēts žokḷa stāvoklis netraucē cilvēkam runāt bez jūtamiem teiktã uztveres traucējumiem;

2) vēža gadijumā izoperējot kādu mēles muguras dału, pacienti ar laiku iemācās izrunāt traucêtās skaṇas vairāk vai mazāk tuvu ideālformai atkarībā no izoperētās mēles dajas lieluma.

Viss iepriekš minētais norāda uz mūsu apzinnā eksistējošu skaṇu ideālformu esamību, kuras valodniecībā saistītas ar fonēmas jēdzienu. Fonētiķi krietni nopūlējušies dažādu ideālformas izpausmju pētī̌sanā un aprakstī̌sanā un secinājuši, ka ideālforma ir kompleksa parādība, kas veidota vismaz no četriem pamatelementiem akustiskās, auditīiās, neiromotoriskās un artikulārās ideālformas (Rosner \& Pickering 1994: 281.-285. Ipp.). Šie elementi ir vienota veseluma dažădas izpausmes, kas savstarpēji ir cieši saistītas.

Apkopojot dažādos avotos dotās patskaņa ideālformas definīcijas un skaidrojumus (Clark \&Yallop 1990; Kent \& Read 1992; Rosner \& Pickering 1994 u.c.), var secināt, ka katra patskaña ideālformas pamatu veido runātāja subjektīvais priekšstats par katras fonēmas ideālo skanējumu. Domājams, ka fonēmu (arī patskaṇu) prototipi jeb ideālformas veidojas valodas apguves procesā, kad no

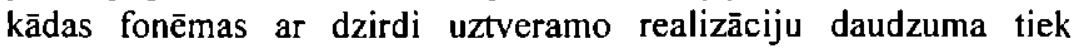
izvēlēts viens variants, kas valodas apguvēja apziṇā tiek saistīts ar dotās fonēmas ideālo skanisko veidolu. Tā, uz akustiskās informācijas pamata veidojas auditīvais prototips, kuru valodas apguvējs cenšas atdarināt savā izrunā, kontrolējot savu pūliṇu rezultātus ar dzirdi un vêrojot apkārtējo cilvēku reakciju. Tāâd auditīvais prototips jeb ideālforma ir tā atskaites vienība, ar kuru tiek salīdzināta gan paša, gan citu izrunas rezultātā radītā skaṇa. Akustiskais signāls, kas atbilst šādai auditīvai ideālformai, veido akustisko ideālformu, kam piemīt noteiktas fizikālas īpašības. Skaṇa, 
kuras fizikālās īpašĭbas atbilst akustiskajai ideālformai, savukārt, tiek izrunāta, veidojot noteiktu artikulatoru stāvokli artikulāro ideālformu, ko panāk ar atbilstošo nervu un muskulu darbības palīdzỉbu, kas, savukārt, veido neiromotorisko ideālformu. Tas, ka kurliem cilvēkiem ir traucēta runas spēja, vedina domāt, ka audit̄̄ōa ideālforma ir viena no svarīgākajām ideālformas kopējā jēdziena da|ām. Tomēr jāatzīst, ka auditīvā ideālforma nevar veidoties bez skaniskã signāla jeb akustiskās ideãlformas esamības.

Noteiktas akustiskā signāla ìpašības ietekmē ar dzirdi uztveramās skaṇas kvalitāti. Raksturojot šo īpašĭbu kopumu, var raksturot skaṇas akustisko ideālformu. Zinot, kā dzirdes mehānisms apstrādā akustisko signālu, un aprakstot uztverē nozīmīgās vienības, var raksturot auditīvo ideālformu. Artikulārās ideālformas aprakstu veido skaṇas izrunā iesaistīto runas orgānu stāvok la un darbības raksturojums, bet neiromotoriskās šo stāvok|u sasniegšanā un darbībā iesaistîto nervu un muskulu darbības apraksts. No visām patskaṇu ideālformas veidojošām da|ām latviešu fonētiḳi ir samērā plaši pētījuši un aprakstījuši patskaṇu artikulārās ideālformas (Laua 1961) un nedaudz arī akustiskās ideālformas (Stelle 1971). Lai gan skaṇu, arī patskaṇu, fonoloğiskā klasifikācija balstīta galvenokārt uz katrai skaṇai piemītošo artikulāro škīiējpazīmju kopuma noteikšanu, t.i., artikulārās ideālformas aprakstu, viss par valodas apguvi, artikulācijas polimorfismu un artikulāro kompensāciju teiktais vedina domāt, ka vienlīdz svarīgas vai pat svarīgākas būtu ziṇas par akustisko un auditīvo ideālformu īpašībām. Akustisko ideālformu apraksts īpaši lielu nozīmi iegũst sakarā ar valodas tehnologijas attīstību, kad rodas nepieciešamỉba pēc inākslīgās runas sintēzes un automātiskas runas atšifrěšanas, t.i. "runājošǎm" un "dzirdošām" ierīcēm, kas atvieglotu cilvēka dzīvi.

Lai papildinātu jau esošo akustisko informāciju par patskaņiem un dotu iespējamo latviešu valodas patskaņu akustisko ideālformu raksturojumu, tika veikts eksperimentāls pētījums. Tā kā runa ir par patskanu akustisko ideālformu noteikšanu un to îpašîbu aprakstī̌sanu, ir jānorobežojas no latviešu valodas patskaṇu akustisko īpašỉbu pêtišanas dabiskā vai laboratoriskiem apstākliem pielāgotā 
runā, kā arī pētījumiem īpaši izraudzītu teikumu vai atsevišķu vārdu izrunā, jo šajos gadỉjumos ideālformas realizāciju ietekmē konkrētā runas situācija, runātāja individuālās īpatnības, runas temps, fonētiskā apkaime un citi faktori. No lielākās da|as minēto ietekmju ir iespējams izvairīties, pētījot izolētu patskaṇu izrunu. Pirmkārt, izrunājot patskani izolēti, tā kvalitāti neietekmē ne fonētiskā apkaime, ne vārda vai zilbes uzsvars, ne runas temps, bez tam intonācija parasti ir krītoša (intonācijas vienveidība ir īpaši svarīga garo patskaņu kvalitātes aprakstā). Otrkārt, izrunājot kādu skaṇu izolēti, runātājs bieži neapzināti cenšas to izrunāt maksimāli "skaidri", t.i., pēc iespējas tuvu dotās skaņas stereotipam jeb ideālformai, kas valodas apguves procesā ir nostiprinājusies viṇa apziṇā. Šeit varētu iebilst, ka pat izolētā izrunā nevar izvairīties no atsevišķu runātāju fiziologisko ipatnību un izrunas ieradumu ietekmes uz patskaņu ideālformu realizāciju un ka šādi iegūts patskaṇu ideālformu apraksts atbilst dotā runātāja individuālo un valodas sistēmai piemītošo īpašību summas aprakstam. No tā izriet, ka objektīvu latviešu valodas patskaṇu akustisko ideālformu aprakstu varētu iegūt tikai, nosakot visu valodas runātāju individuālo ideālformu īpašības un aprēḳinot no tām vidējās statistiskās vērtỉbas. Šāds darbs nebūtu praktiski paveicams tā lielā apjoma dē]. Statistikas teorija liecina, ka samērā objektīvu informāciju par kādu veselumu var iegūt, pētījot nelielu šĩ veseluma dalu. Balstoties uz šo pieṇēmumu, var samazināt darba apjomu, tomēr aktuāls paliek jautājums - cik lielā mērā izvēlētajā dạāa novērotās ìpašības atbilst visā veselumā vērojamām.

Pasaules fonētiķu prātus jau vairākus gadu desmitus nodarbina jautājums, kā nošķirt skaniskajā materiālā tā objektīvo (valodai raksturīgo) dalu no subjektīvās (katra runātāja individuālo īpašỉbu noteiktās). Viens no veidiem, kā samazināt runātāju atšķirību ietekmi uz valodas skaṇu objektīvajām īpašībām, ir aprakstīt skaṇas no uztveres psihofizikālā viedok|a. Šādi tiek atdarinăta dzirdes aparāta veiktā akustiskā signāla datu normalizēšana, kuras rezultātā tiek samazinātas subjektīvo faktoru noteiktās atškirīības. Šajā darbā lietotais uzlabotais patskaṇu ideālformas modelis (Kent \& Read 
1992: 90.-91.lpp.) ir balstīts uz skaṇas formantu centru frekvenču akustisko datu nelineāra pārveidojuma psihofizikālās uztveres vienībās (melos, barkos, kēnigos, erbos utt.). Pētījumā lietota barku skala, kuras vienïba ir viens barks (1 Bark). Barku skala atspogulo iekšējās auss gliemeža darbību, kad uz noteiktas skaṇas akustiskā signāla frekvenču joslas izraisītu kairinājumu reağè noteikta auss gliemeža josla, ko sauc par kritisko joslu. No vairākiem barku skalas modeliem savam pētījumam izvēlējos $\mathrm{H}$. Traunmillera izstrādāto, jo tas lietots arī A. Ēka un E. Meistera veiktajā igauṇu valodas patskaṇu pētījumā (Eek \& Meister 1994). Šādā veidā abu pētījumu dati k|̄̄śst savstarpēji salīdzināmi. Patskaņu formantu centru frekvenču skaitlisko lielumu pārveidojumam no akustiskajām vienībām, kas izteiktas hercos $(\mathrm{Hz})$, uztveres psihofizikālajās vienībās, kas izteiktas barkos (Bark), lietota H. Traunmillera 1988. gada formula (Traunmüller 1988):

$$
z=(26,81 \times f /(1960+f))-0,53
$$

Šajā formulā $\mathrm{z}$ - kritisko joslu rādītājs barkos (Bark), bet $\mathrm{f}$ frekvence hercos $(\mathrm{Hz})$.

Ja $\mathrm{z}<2,0$ barkiem, lietota cita $\mathrm{H}$. Traunmillera formula:

$$
\mathbf{z}^{\prime}=\mathbf{z}+\mathbf{0 , 1 5}(\mathbf{2}-\mathrm{z})
$$

Šajā formulā $z$ - kritisko joslu rādītājs barkos, kas iegūts, izmantojot 1 . formulu un ir mazāks par 2 barkiem $(z<2,0)$, bet $z^{\prime}$ galīgais kritisko joslu rādītājs barkos.

Lai vēl vairāk samazinătu runātāju individuālo īpaš̄̌bu ietekmi uz objektīvo skaņas signālu, ieteicams patskaņus raksturot nevis ar to formantu centru absolūtajiem psihofizikālajiem lielumiem, bet gan ar patskaṇu pirmo tris formantu $(\mathrm{F} 1, \mathrm{~F} 2, \mathrm{~F} 3)$ savstarpējo attiecību koeficientiem (F2/F1; F3/F2) vai intervālu lielumiem starp šiem formantiem (F2-F1; F3-F2). Jāpiezīmē, ka atsevišķo patskañu grupēšana fonēmas robežās un dažādu fonēmu nodalī̌sana akustiskajā vai psihofizikālajā plaknē, balstoties uz intervālu lielumiem starp patskaṇu formantiem, vislabākos rezultātus dod, lietojot barku skalu un attēlojot patskaṇus kă punktus psihofizikālajā plaknē (Miller 1989: 2119. lpp.). Lietojot akustiskās vai citas psihofizikālās mērvienības, labākie rezultāti sasniedzami, 
logaritmiski izsakot patskaṇa pirmo trīs formantu savstarpējo attiecību skaitliskos lielumus $\left(\log _{10}(F 2 / F 1) ; \log _{10}(F 3 / F 2)\right)$. S̄ādã gadījumā mērvienību izvēle samērā maz ietekmē iegūto rezultātu (Miller 1989). Uzlabotais patskaṇa ideālformas modelis ir ne tikai ekonomisks, jo jauj raksturot katra patskana ideālformas tikai ar šī patskaña formantu centru skaitliskajām vērtībām, kas izteiktas ar psihofizikālo mērvienību skaitliskajiem lielumiem, bet nav arī pretrunā ar auditīiās ideālformas teorijām (Kuhl 1991). Dažāàdi eksperimenti liecina, ka akustiskā ideālforma ir pietiekami raksturojama ar patskaṇa formantu centru skaitliskajām vērtībām, kas iegūtas, izdarot mērījumus artikulācijas izturējuma fāzei atbilstošajā dinamiskās spektrogrammas kvazinemainīgā posma vidusdajā (Fox 1983; Harrington \& Cassidy 1994; Jenkins et al. 1983 u.c.).

\section{PĒTIJJUMA MATERIALLS UN TĀ MËRIJJUMI}

Latviešu valodas patskaṇu akustisko ideālformu noteikšanai tika izmantoti visi 12 latviešu valodas patskaṇi: /i/, /i:/, /e/, /e:/, /a /, $/ \mathfrak{x}: /, / \mathrm{a} /, / \mathrm{a}: /, / 0 /, / 0: /, / \mathrm{u} /$ un $/ \mathrm{u}: /$ (sistēmas labad arī /o/ un /o:/, lai gan tie būtu uzskatāmi par vienas fonēmas variantiem, jo atšḳirỉbā no citiem īsā un garā patskaņa pāriem šo patskaṇu ilguma atškirīibai nav nozīmes škīiējfunkcijas). Patskaņu izrunas ierakstam tika izraudzīti 3 informanti (vīrieši - V1, V2, V3) vecumā no 23 līdz 35 gadiem, kuru izrunu var raksturot kā skaidru un bez runas defektiem esošu. Ieraksta laikā katrs informants trīs reizes izrunāja katru no 12 patskaṇiem. Materiāls tika ierakstīts kvalitatīvā magnetofona lentē SONY, izmantojot augstas klases stacionāru kasešu magnetofonu SONY TC-FX2 un kondensatoru elektretu mikrofonu MKE-100 ELEKTRET, kura uztveramo frekvenču josla ir $5020000 \mathrm{~Hz}$. Mikrofons tika novietots $30 \mathrm{~cm}$ attālumā no informanta lūpām, lai nodrošinātu maksimāli efektīvu zemo frekvenču uztveršanu un ierakstu. lerakstot tika kontrolēts, lai visi patskaṇi būtu izrunāti ar krītošo intonāciju. Lai părbaudītu lietotās aparatūras iespējamo 
ietekmi uz ierakstītā skaṇas signāla kvalitāti, salīdzināšanai tika papildus izdarīts informanta V2 izrunāto garo patskaṇu ieraksts Igaunijas ZA Kibernētikas institūta Fonētikas un runas tehnologijas laboratorijas bezatbalss telpā, ierakstam izmantojot augstas kvalitātes digitālo kasešu magnetofonu CASIO DA-7 un dinamisko mikrofonu SHURE PROLOGUE 14H. Abu ierakstu kvalitāte tika salīdzināta, analizējot ierakstīto skaṇas signālu ar profesionālas, akustiskās fonētikas pētijumiem paredzētas iekārtas KAY CSL 4300 palīdzību. Nelielās abu ierakstu kvalitātes atškirỉibas absolūti neietekmêjja interesējošo patskaṇu analīzes precizitāti, tâpēc tika secināts, ka Rīgā ierakstītā materiāla kvalitāte atbilst pêtījuma mērḳu noteiktajām prasībām.

Informantu V1, V2 un V3 izrunāto izolēto patskaṇu ieraksti tika analizēti Latvijas Universitātes Matemātikas un informātikas institūta Mākslīgã intelekta laboratorijā, lietojot personālajiem IBM tipa datoriem paredzētu akustiskās analīzes programmu CSRE 4.5 (Canadian Speech Research Environment, versija 4.5, darbības vide - DOS, ražotājs - AVAAZ Innovations Inc.). Programma bija instalēta datorā ar PENTIUM $166 \mathrm{Mhz}$ procesoru. Programmas vadītā skaņas akustiskā signāla pārveidošana no analogā uz digitālo un atpaka) notika ar skaņu kartes SOUND BLASTER 16 (ražotājs Creative Labs) starpniecību. Analogā skaṇas akustiskā signāla pārveidošana digitālajā veikta ar $12,5 \mathrm{kHz}$ diskretizācijas frekvenci un 16 bināro vienību amplitūdas kvantizēšanu. Akustiskā enerğija virs $5000 \mathrm{~Hz}$ nofiltrēta ar akustisko filtru. Patskaṇu akustiskā kvalitāte noteikta, novietojot vertikālo kursoru uz monitorā redzamās dinamiskās spektrogrammas kvazinemainīgā posma vidusda|as un nolasot ar LPC MC metodi (Linear Predictive Coding Modified Covariance method) noteiktās formantu centru frekvenču skaitliskās vērtibas. Patskaṇu ilgumi noteikti, mērījot katra patskaṇa skaṇas viḷna ilgumu no svārstību pirmā cikla sākuma līdz pēdējā cikla beigām. Pamattoṇa (F0) līkne izskait|ota ar atlasošās filtrēšanas metodi (Comb Filtering method, frekvences augšèjā robeža 500 $\mathrm{Hz}$ ), kas deva iespëju noteikt pamattoṇa frekvences augstāko un zemāko, kā arī vidējo skaitlisko vērtību viena patskaṇa robežās. No 
šīm vêrtỉbām mērījumu rezultātos norādītas pamattoṇa vidējās vērtības patskaṇa robežās.

Mērījumos iegūtie akustiskie dati apstrādāti ar statistikas programmu SPSS (SPSS Advanced Statistics, versija - 7.0 Update, darbības vide Windows 95, ražotājs - SPSS Inc.), aprēḳinot katra patskaņa ilguma, pamattona un pirmo četru formantu (F1, F2, F3 un F4) centru frekvenču vidējās statistiskās vērtỉbas un standartnovirzes. Šādi iegūtie rezultāti redzami 1. tabulā.

1. tabula. Latviešu valodas garo un iso patskaṇu pamattoṇa un pirmo četru formantu frekvenču vērtības hercos $(\mathrm{Hz})$ un ilguma vērtības milisekundēs (ms). Katram patskanim norādītā vidējā statistiskã vërtība (VSV) un standartnovirze (SN) aprēḳinātas trīs informantu trīs reizes izrunātiem patskaṇiem.

\begin{tabular}{|c|c|c|c|c|c|c|c|c|c|c|c|c|}
\hline \multirow[t]{2}{*}{ Patsk } & \multicolumn{2}{|c|}{ Fo } & \multicolumn{2}{|c|}{ FI } & \multicolumn{2}{|c|}{$\mathbf{F} 2$} & \multicolumn{2}{|c|}{ F3 } & \multicolumn{2}{|c|}{ F4 } & \multicolumn{2}{|c|}{ Ilgums } \\
\hline & VSV & SN & VSV & SN & VSV & SN & VSV & SN & $\overline{\text { VSV }}$ & SN & VSV & SN \\
\hline hi:/ & 117 & 11 & 286 & 42 & 2189 & 76 & 2947 & 155 & 3734 & 286 & 487 & 156 \\
\hline ij & 128 & 7 & 312 & 52 & 2182 & 73 & 2894 & 196 & 3700 & 275 & 207 & 34 \\
\hline /e:/ & 114 & 14 & 426 & 26 & 1975 & 92 & 2644 & 117 & 3469 & 75 & 481 & 159 \\
\hline$/ \mathrm{d} /$ & 118 & 9 & 458 & 37 & 1921 & 66 & 2630 & 129 & 3483 & 127 & 208 & 40 \\
\hline /x:/ & $1 \sqrt{3}$ & 16 & 681 & 58 & 1532 & 85 & 2488 & 51 & 3442 & $\overrightarrow{125}$ & $\overline{493}$ & 118 \\
\hline$/ \mathbf{x} /$ & 111 & 9 & 675 & 60 & 1564 & $B 1$ & $24 B 5$ & 44 & 3475 & 225 & 219 & 33 \\
\hline$/ \mathbf{a}: /$ & 110 & 12 & 657 & 50 & 1005 & 52 & 2668 & 70 & 3452 & 109 & 501 & 114 \\
\hline$/ a /$ & 108 & 9 & 690 & 63 & 1044 & 69 & 2546 & 144 & 3458 & 168 & 229 & 40 \\
\hline $10: 1$ & 112 & 11 & 468 & 31 & 731 & 55 & 2503 & 167 & 3371 & 116 & $48 B$ & 127 \\
\hline /o/ & 112 & 10 & 509 & 34 & 787 & 53 & 2474 & 81 & 3334 & 102 & 229 & 44 \\
\hline /u:/ & 120 & 10 & 325 & 41 & 589 & 51 & 2239 & 104 & 3210 & 88 & 436 & 110 \\
\hline$/ \mathrm{u} /$ & 120 & 8 & 323 & 54 & 642 & 79 & 2350 & 158 & 3121 & 60 & 192 & 25 \\
\hline
\end{tabular}

Izmantojot iegūtos datus (skat. 1. attēlu 174. Ipp), patskañus var attēlot kā punktus akustiskajā F2/F1 plaknē. Šajā attēlā (F2/F1 plaknē) horizontālā ass rāda otrā formanta (F2) vērtību lielumu un apmēram atbilst artikulācijas vai nosacīti mēles augstäkả pacēluma vietai, bet vertikālā ass - pirmā formanta (Fl) vērtību lielumu, kas nosacīti saistīts ar mēles pacēluma vai mutes vēruma apjomu (skat. 1. attēlu!). 


\section{MẼRIJUMOS IEGUTTO AKUSTISKO DATU PÄRVEIDOJUMS PSIHOFIZIKĀLAJOS}

Lai patskaṇu apraksts atbilstu uzlabotā patskaṇu ideālformas modeja prasībām, patskaņu formantu centru frekvenču mērijjumos iegūtie akustiskie dati ir jāpārveido psihofizikālajos, lai tādā veidā samazinātu dažădu runātāju individuālo īpašību ietekmi samazināšanu uz patskaņu objektīvajām akustiskajām īpašībām. Lietojot H.Traunmillera 1988. gada formulas, mērijjumos iegūtie dati tika pārrẹệnāti barkos un statistiski apstrādāti. Pārveidoto datu statistiskās apstrādes rezultāts ir redzams 2 . tabulā.

2. tabula. Latviešu valodas garo un iso patskaṇu pamattoṇa un pirmo četru formantu frekvenču psihofizikālās vērtības barkos (Bark). Vērtibas aprēḳinātas pēc H.Traunmillera 1988. gada formulas. Katram patskanim norädītā vidējā statistiskā vērtība (VSV) un standartnovirze (SN) aprēkinātas trīs informantu trīs reizes izrunātiem patskañiem.

\begin{tabular}{|c|c|c|c|c|c|c|c|c|c|c|}
\hline \multirow[t]{2}{*}{ Patsk. } & \multicolumn{2}{|c|}{ F0 } & \multicolumn{2}{|c|}{ F1 } & \multicolumn{2}{|c|}{ F2 } & \multicolumn{2}{|c|}{ F3 } & \multicolumn{2}{|c|}{ F4 } \\
\hline & VSV & SN & VSV & $\overline{\text { SN }}$ & VSV & SN & VSV & SN & VSV & SN \\
\hline li: & 1,14 & 0,12 & $2,8 \overline{8}$ & 0,43 & 13,61 & 0,23 & 15.56 & 0,35 & 17,03 & 0,46 \\
\hline ii) & $\mathrm{I}, 25$ & 0.10 & 3.14 & 0,53 & 13,59 & 0,22 & 15,44 & 0,44 & 16,98 & $\overline{0,44}$ \\
\hline /e:/ & 1,11 & 0,14 & 4.25 & 0,24 & 12,92 & 0,32 & 14,86 & 0,28 & 16.60 & 0,14 \\
\hline $7 \mathrm{e} /$ & 1,14 & 0,10 & 4,54 & 0,33 & 12,74 & 0,23 & 14,82 & 0,32 & 16,62 & 0,23 \\
\hline$\overline{\mid x: /}$ & 1,09 & 0,16 & 6,37 & 0,44 & 11,23 & 0,36 & 14,46 & 0,14 & 16,55 & 0,22 \\
\hline$|\boldsymbol{x}|$ & 1,07 & 0.10 & 6,33 & 0,44 & 11.36 & 0,34 & 14,46 & 0,12 & 16.60 & 0.41 \\
\hline /a: & 1,06 & 0,13 & 6,20 & 0,38 & 8,56 & 0,31 & 14,92 & 0,17 & 16,57 & 0,20 \\
\hline$/ \mathrm{a} /$ & {$[, 04$} & 0,10 & 6.44 & 0,47 & 8,78 & 0,40 & 14,61 & 0,37 & 16.57 & 0,31 \\
\hline $10: 1$ & 1,08 & 0,11 & 4,64 & 0,28 & 6,75 & 0,40 & 14,49 & 0.44 & 16,42 & 0,22 \\
\hline $10 /$ & 1,09 & 0,10 & 5,00 & 0,29 & 7,15 & 0,37 & 14,42 & 0.22 & 16.35 & 0,19 \\
\hline /u:/ & 1,17 & 0.11 & 3,28 & 0,41 & 5,66 & 0,41 & 13,76 & 0,30 & 16.11 & 0.18 \\
\hline$/ \mathrm{u} /$ & 1.16 & 0.11 & 3,26 & 0,55 & 6,07 & 0,61 & 14,08 & 0,44 & 15,94 & 0,12 \\
\hline
\end{tabular}

Ja salīdzina iso un garo patskaṇu formantu centru psihofizikālās vērtîbas (2. tabula), redzams, ka nevienam garā un īsā patskaṇa pārim šo vērtību starpība nepārsniedz 1 barku. Tas, ka gan fizikālajā, gan psihofizikālajā F2/F1 plaknē garo un îso patskaņu koordināšu F1 un F2 noteiktie punkti lielā mērã pārklājas un ka garo 
un iso patskaṇu formantu centru psihofizikālo vērtibu starpỉba nepārsniedz 1 barku (caurmērā tā nepārsniedz pat 0,5 barkus - skat. 2. attēlu!), liek secināt, ka garajiem un īsajiem patskaṇiem ir jāatbilst vienai un tai pašai patskaṇu kvalitātes kategorijai (livonen 1987). Šis pêtījums tādā veidā apstiprina tradicionālo pieñēmumu (Laua 1961 u.c.), ka latviešu valodā, līdzīgi igauņu un somu valodai, garo un iso patskaṇu fonologiskās atšķirỉbas pamatojas uz kvantitatīvajām (relatīivo ilgumu attiecības) un nevis kvalitatīvajām attieksmēm. Līdz ar to var apgalvot, ka latviešu valodā patskaṇu ilgums kalpo kā fonologiska norāde (Phonological marker Rosner \& Pickering 1994), kad garā un isãa patskaṇa fonēmas patskaņu pārī tiek šķirtas balstoties uz to relatīvo ilgumu attiecības. Latviešu valodã patskaṇu relatîvo ilgumu attiecība vidēji ir $1 \div 2,3$, t.i., garā patskaṇa ilgums ir vidēji 2,3 reizes lielāks par ìsā patskaña ilgumu. Spektrālās atšksirības šai gadījumā kalpo kā palīgfaktors, kas sekmē garo un īso patskaṇu fonēmu nošķiršanu, bet pats to nenosaka. Pētījumā iegūtie dati atbilst arī citu valodu (kurās ilgums kalpo kā fonologiska norāde) pētījumos novērotajām tendencēm, ka salīdzinājumā ar garajiem patskaṇiem issie patskaṇi ir novirzīti akustiskās vai psihofizikālās F2/F1 plaknes centra virzienā (skat. 1. un 2. attēlu! 1.74. un 175. lpp.), taču šĩ novirze nav tik liela, lai varētu runāt par iso patskaṇu piederību citai kvalitātes kategorijai.

Akustiskās fonētikas literatūrā patskaṇu plaknes grafiskajos attēlos bieži ir izmantota nevis $\mathrm{F} 2 / \mathrm{F} 1$, bet gan $\mathrm{F} 1 /(\mathrm{F} 2-\mathrm{F} 1)$ koordinātu plakne. Šāds attēlojums tiek pamatots ar to, ka, izmantojot starpību F2-F1, tiek iegūts attēls, kas ir tuvāks patskaṇu aprakstam no artikulāro pazīmju viedokla, tā uzlabojot saikni starp artikulācijas vietas attēlojumu akustiski auditīvajos un artikulārajos grafikos. Tas saskan ar Dž. Millera (Miller 1989) un citu fonētiķu hipotēzi, ka uztverē intervālu lielumi starp patskaṇa formantiem ir daudz svarīgāki par šo formantu centru absolūtajām skaitliskajām vērtībām. Tā kā pêtîjumi (Traunmüller 1981; Traunmüller \& Lacerda 1987) rāda, ka nevis F1 absolūtā skaitliskā vērtība, bet gan tonotopiskā distance F1-F0 jeb intervāls starp pamattoni F0 un pirmo formantu 
F1 ir galvenais patskaṇa platuma (mēles pacēluma un mutes vēruma) rādītājs un ka patskaṇa artikulācijas vietu labāk par F2 absolūto skaitlisko vērtību izsaka tonotopiskā distance F2-F1, labāku priekšstatu par patskanu savstarpējo novietojumu var iegūt, attēlojot tos auditīvajā (F1-F0)/(F2-F1) plaknē (skat. 3.attēlu! 176.lpp.).

Šāds grafiskais attēlojums saskan ar telpisko paraugu teoriju (Space Pattern Theory), kas nosaka, ka noteiktas skanas pazimes tiek atpazītas pēc skaṇas izraisītās iedarbības uz iekšējās auss gliemeža basilārās membrānas dažādām vietām telpisku paraugu jeb klišeju veidā (Traunmüller 1981). Telpiskie paraugi jeb klišejas ir cieši saistīti ar enerḡētisko joslu jeb formantu savstarpējo izvietojumu skaṇas spektrā. Līdz ar to tonotopiskās distances starp formantu centriem (Traunmüller 1981) vai formantu centru skaitlisko vērtību attiecỉbas (Miller 1989) sniedz svarīgāku informāciju par patskaṇu kvalitāti nekā patskaņu formantu centru absolūtās vērtības. Salīdzinājumam jāskata 4.attēls (177.lpp.), kurā visu 3 informantu atsevišķie dati attēloti F2/Fl psihofizikālajā plaknē. Šajā attēlā datu noteiktie atseviškie punkti ir daudz vairāk izkliedēti. Tas apstiprina hipotēzi, ka atsevišķu runātāju atškiriribu novēršanai palīdz patskaṇu raksturošana ar tonotopiskajām distancēm starp patskaṇa formantiem. 
1. attẻls. Latviešu valodas garo un īso patskaṇu attēlojums akustiskajā F2/F1 plaknēe Ar melniem aplīšiem attēloti garie patskaṇi, bet ar baltiem trīsstūriem - īsie patskaṇi.

Koordinātēm kalpo l. tabulā redzamie skaitliskie dati.

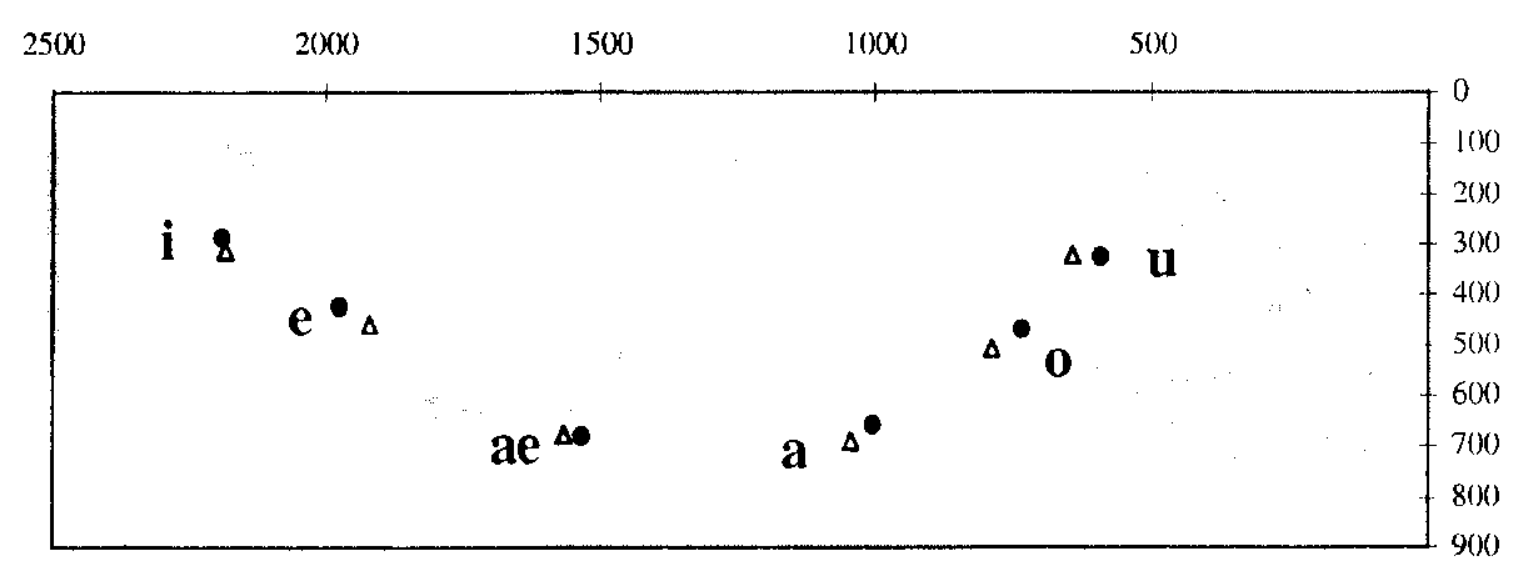


2. attēls. Latviešu valodas garo un īso patskaṇu attēlojums psihofizikālajā F2/Fl plaknē. Ar melniem aplīšiem attēloti garie patskaṇi, bet ar baltiem trīsstūriem - ìsie patskaṇi.

Koordinātēm kalpo 2. tabulā redzamie skaitliskie dati.

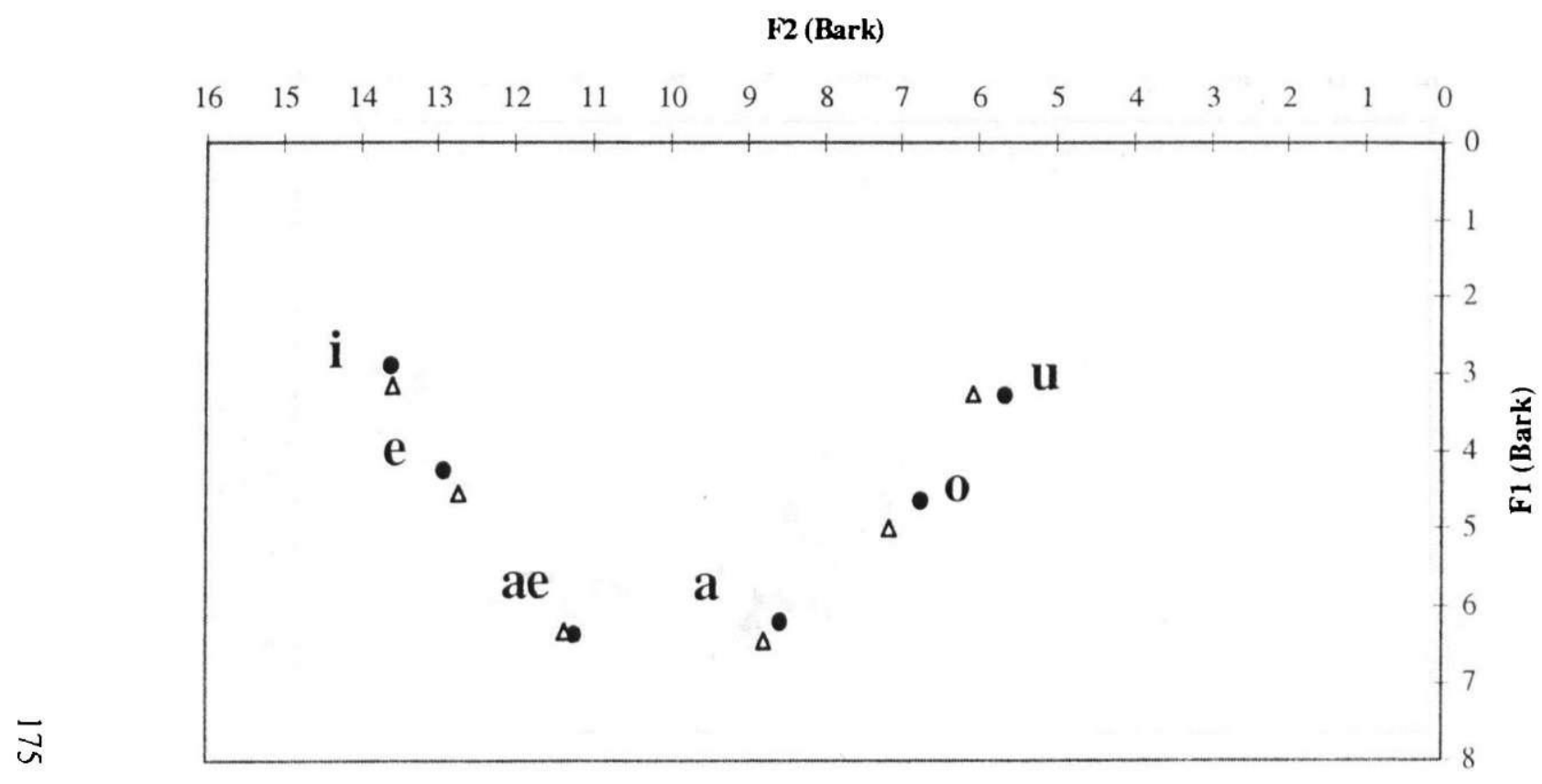




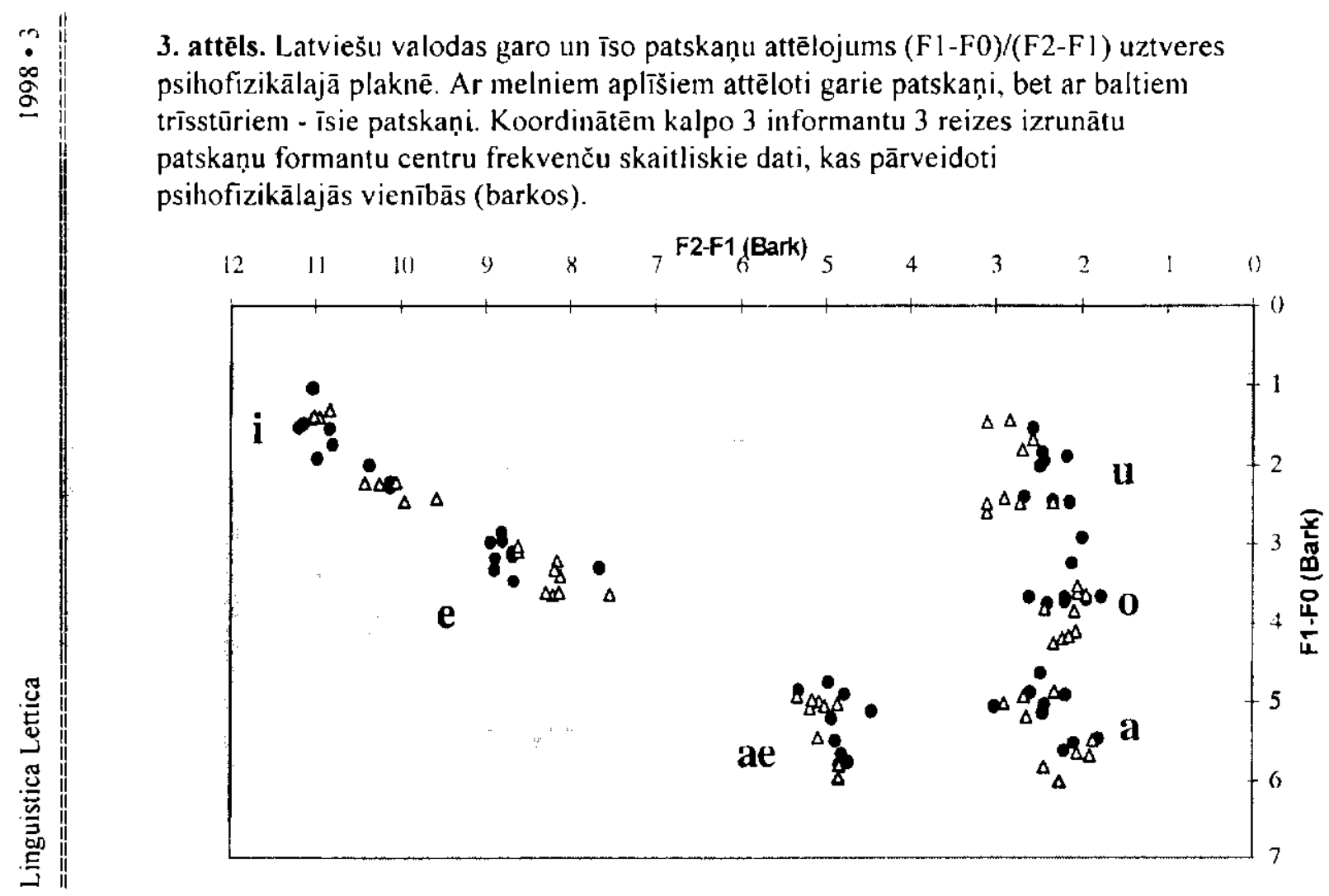


4. attēls. Latviešu valodas garo un īso patskaṇu attēlojums psihofizikālajā $F 2 /[\overline{1}]$ plaknēe. Ar melniem aplīšiem attēloti garie patskaṇi, bet ar baltiem trīsstūriem'- isie patskaṇi. Koordinātēm kalpo 3 informantu 3 reizes izrunātu patskaṇu formantu centru frekvenču skaitliskie dati, kas pārveidoti psihofizikālajās vienībās (barkos).

F2 (llark)

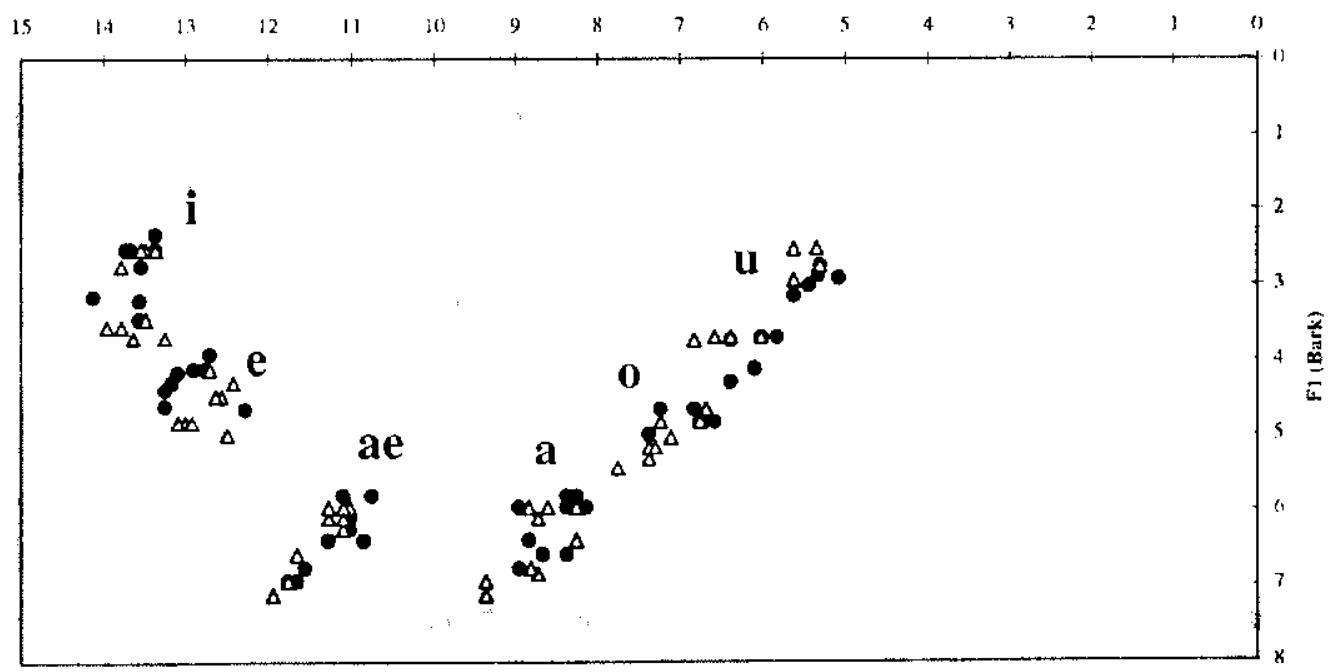




\section{LITERATÜRA:}

Clark \& Yallop Clark, J. and Yallop, C. (1990). An Introduction 1990 to Phonetics and Phonology. Oxford: Basil Blackwell Ltd.

Eek \& Meister Eek, A. and Meister, E. (1994). "Acoustics 1994

Fox 1983 and perception of Estonian vowel types", in PERILUS, 18, 55 - 90 .

Fox, R. (1983). "Perceptual structure of monophthongs and diphthongs in English", in Language and Speech, 26, $21-60$.

Harrington \& Harrington, J. and Cassidy, S. (1994). "Dynamic Cassidy 1994

Iivonen 1987 and target theories of vowel classification: Evidence from monophthongs and diphthongs in Australian English", in Language and Speech, $37,357-373$.

livonen, A. (1987). "The critical band in the explanation of the number of possible vowels and psychoacoustical vowel distances", in Helsingin yliopiston fonetiikan laitoksen monisteita, 12, Helsinki.

Jenkins et al. Jenkins, J., Strange, W and Edman, T. (1983). 1983

Kent \& Read 1992

Kuhl 1991 "Identification of vowelsin "vowelless" syllables", in Perception and Psychophysics, 34, 441 - 450. Kent, R. and Read, Ch. (1992). The Acoustic Analysis of Speech. San Diego, California: Singular Publishing Group, Inc.

Kuhl, P (1991). "Human adults and human infants show a "perceptual magnet effect" for the prototypes of speech categories, monkeys do not", in Perception and Psychophysics, 50, $93-107$.

Ladefoged 1989 Ladefoged, P. (1989). "Representing Phonetic Structure", in UCLA Working Papers in Phonetics, 73. 
Laua 1961

Lindblom 1963

Miller 1989

Rosner \&

Pickering 1994

Stelle 1971

Traunmüller 1981

Traunmüller 1988

Traunmüller \& Lacerda 1987
Laua, A. (1961). Mūsdienu latviešu literārās valodas fonētikas jautājumi. Rīga: kand. dis. Lindblom, B. (1963). "Spectrographic study of vowel reduction", in Journal of the Acoustical Society of America, 35, 1773 - 1781. Lindblom, B. (1984). "Economy of speech gestures", in The Production of Speech (ed. P. MacNeilage). New York: SpringerVerlag.

Miller, J. (1989). "Auditory-perceptual interpretation of the vowel", in Journal of the Acoustical Society of America, 85, 2114 - 2134. Rosner, B. and Pickering, J. (1994). Vowel perception and production. Oxford: Oxford University Press.

Stelle, A. (1971). Latviešu literārās valodas uzsvērtā vokālisma akustisks skaidrojums. Rīga: kand. dis.

Traunmüller, H. (1981). "Perceptual dimension of openness in vowels", in Journal of the Acoustical Society of America, 69, 1465 - 1475. Traunmüller, H. (1988). "Analytical expressions for the tonotopic sensory scale", in PERILUS, $8,93-102$.

Traunmüller, H. and Lacerda, F. (1987). "Perceptual relativity in identification of two-formant vowels", in Speech Communication, $6,143-157$. 


\section{DETERMINATION OF LATVIAN ELABORATED VOWEL TARGET MODEL Summary}

In Phonetics it is useful to deal with the complex of vowel targets (articulatory, acoustic, auditory and neuromotor) as the realisation of the concept of Phoneme. Due to different reasons mainly the articulatory vowel targets have been investigated and described by Latvian phoneticians and therefore the purpose of the present study was to give more detailed information about the acoustic vowel targets of Standard Latvian. This necessity is based in the growing needs for such information due to the fast development of language technology both in Europe and Latvia. The Elaborated Vowel Target model has been chosen for the description of acoustic targets of Latvian vowels as it takes into account the normalisation procedure of vowel formant data performed by human auditory system. Sustained isolated vowels were used as the material for recordings and analysis because their acoustic quality is the nearest to the acoustic quality of vowel targets. The pronunciation of isolated Latvian vowels by three male informants (out of 20 used in previous investigations) was recorded and analysed using the programme CSRE 4.5 (AVAAZ Innovations Inc.). The method used for the analysis was LPC MC (Linear Predictive Coding Modified Covariance). The programme SPSS (SPSS Advanced Statistics, 7.0 Update, SPSS Inc. for Windows 95) was used to calculate the mean values and standard deviations of duration, pitch and formant centre frequencies for the first four formants of each vowel (Table 1). According to the theory of elaborated vowel target model these acoustic data were transformed into psychophisical units (Table 2) using H. Traunmüller's formulas (Traunmüller 1988). Comparing formant data of long and short monophthongs it is apparent that they belong to one and the same category of vowel quality (Iivonen 1987). Thus the quantitative relations between short and long monophthongs $(1 \div 2,3)$ in Latvian serve as a Phonological marker not as a Phonological quantity like in English. 


\section{Maija BRĒDE \\ DAŽI VẼROJUMI PAR SONANTA /l/ VARIANTIEM LATVIEŠU VALODĀ}

Skaneñi jeb sonanti valodas fonēmu sistēmā ieṇem īpašu vietu kā līdzskaṇi, kuru sonoritāte tos tuvina patskaņiem. Pēc O. Jespersena (Jespersen, 1926), kā arī R.M.S. Hefnera (Heffner, 1949) sonoritātes tabulas līdzskaṇu grupā tikai skanenim /r/ piemịt vêl lielāka sonoritāte nekā /l/.

No skaneṇu kvalitātes, tāpat kā patskaṇu skanīguma, lielā mērā atkarīga valodas labskaṇa. Lai arī apzīmējums "labskaṇa" uzlūkojams par subjektīvu kritēriju, ir gadījumi, kad vienā valodā runājošie vai pat tie, kas runā valodās ar dažādu genētisko piederību, uzrāda līdzīgus vērtējumu kritērijus. Vispāratzīts labskaṇas pamats valodā ir atvērtās zilbes veids, kā arī noteikta zilbes struktūra, resp. mazskaitlīgas līdzskaņu grupas un kopas. Skaneṇu klātbūtne šādās kopās palīdz veidot vārda melodisko tēlu.

Šos un līdzīga rakstura jautājumus fonostilistikas ietvaros aplūko valodas estētika. Kādas aptaujas rezultāti, kurā ang|u valodā rakstoši autori tika lūgti nosaukt labskanīgākos vārdus, netieši norāda uz skaneṇa / l / lomu, jo minēto vārdu sarakstā sastopami: lullaby, luminous, golden, melody, tranquil, silence, April. Kā redzams, skanenis / l / efektīvi piedalās attiecīgu skaṇu tēlu radīšanā. Arī latviešu valodā fonētisko izteiksmes līdzek/u izmantošanā (aliterācija) / l / ierādīta nozīmīga stilistiska funkcija:

"Ilgi nelijis lietus, liepa un jūlijs.

Lokana laipa, plūdens ūdens.

Siena laiks piena maigs.

San smilgas, süt laksti.

Dienvidus. Liptin līp plaksti.

Mellenes saldas uz galda.

Maigums, lūgums un maldi.

Galotnes līganas, lokanas. 
Lubiṇas, gubenas, lubenes.

Mākoṇi nākoṇi, mākoṇi ejoṇi.

Skūpsti un laksti.

Liptin līp plaksti” (Zālīte, $1997: 28)$

Latviešu valodas / l / artikulācijas aprakstā (Laua, 1997:46) / l / definēts kāapikāli alveolārs priekšējais mēlenis, laterāls spraudzenis, skanenis.

Veicot sistemātisku studentu aptauju par / l / artikulācijas vietu latviešu valodā, konstatēts, ka no 100 aptaujātajiem tikai aptuveni 5-6/1/ izrunā kā apikāli alveolāru skaṇu. Vairākums priekšroku dod apikāli dentālai artikulācijai.

Runājot par / I / lietojumu saistītā runā, latviešu fonētiskajā literatūrā, galvenokārt E.Liepas darbos (Liepa, 1968, 1970), sastopamas norādes uz skaneṇa / l / kvantitātes variantiem. Tāpat kā J.Endzelīna pētījumos / l / atzîts par garāku pozīcijā starp ìsu patskani un līdzskani zilbēs ar stiepto intonāciju ( [balc] balts, [tilc] tilts), kā ar̄i starp nebalsīgiem līdzskaṇiem, kur sonants ir zilbisks ([kakls] kakls).

Daudz detalizētāks sonanta / l / variantu apraksts atrodams, piemēram, anglu valodā. İpaši tas attiecināms uz skaņas artikulācijas vietu asimilācijas gadijjumā. Interesanti atz̄imēt, ka D.Džounss (Jones, 1956, 1967) izdala dažādus / I / variantus atkarā no sekojošā patskaņa ar katram šim patskanim raksturīgo tembrālo nokrāsu. Taču, ja J.Endzelīns (Endzelīns, 1938: 58) savulaik atzinis, ka latvieši / i / un / e / priekšā mēdz izrunāt "gaišāku" / I / nekā / au / un / uo / priekšāan, anglu valodas fonētikas izklāstā visbiežāk sastopama norāde, ka "gaišais" / I / izrunājams pirms patskaņiem, bet "tumšais" pirms līdzskaṇiem, īpaši vārda beigu pozīcijā.

J.Endzelīns arī norädījis, ka "dažviet Vidzemē, arī Kurzemē "tumšais" / I / sastopams palaikam tikai diftongiskos savienojumos ar iepriekšeju patskani, pavisam neievērojot nākamās zilbes patskaṇa kvalitāti”' (Endzelīns, 1951: 202).

A.Lauas aprakstā / I / latviešu valodā atkarībā no mēles konfigurācijas raksturots kā "tumšs", salīdzinot ar līdzīgu skaṇu 
vācu, franču, kā arī ar "gaišo" / / / ang|u valodā. Savukārt, tas ir gaišāks nekā krievu valodā.

Lai veiktu auditivo analīzi, kuras mērḳis bija rast ieskatu skaneṇa / 1 / tembrālo variantu lietojumā, kas nav tieši saistīts ar kādu no izlokšṇu īpatnībām, tika izraudzīta grupa informantu. Tie ir studenti vecumā no 18-20 gadiem, kuri līdz studiju sākumam Rīgā dzīvojuši dažādos Latvijas novados vai arī galvaspilsētā; pēc pašu atzinuma, mājās nav runājuši kādā no dzi|ajām izloksnēm.

Informantu izrunā galvenokārt tika fiksēti divi zilbes intonāçijas veidi - krītošā un stieptā, kas visumā atbilst attiecīgo vārdu izrunas transkripcijai (Ceplītis, 1995). Tembra nokrāsas noteikšanai izraudzīti apzīmējumi "tumšs", "gaišs", "vidēji tumšs", "vidēji gaišs" Materiāla sagatavošanā tika izraudzīti, pirmkārt, tie fonotaktiskie modeli, kuri fonētiskajā literatūrā pieminēti kā noteicošie / I / vienas vai otras tembrālās nokrāsas lietojumā: / l / vienzilbīga un divzilbīga vārda sākumā pirms palatāliem un velāriem patskaņiem, kāarī intervokâlā pozìcijā un vārda beigās aiz patskaña.

Konkrētās anajīzes rezultāti rāda, ka iepriekšējie novērojumi par "gaišā" / l / lietojumu pirms palatāliem patskaṇiem pilnībā neatbilst pašreizējai latviešu valodas izrunai. Tas īpaši attiecas uz vārda săkuma pozīciju. Vairumā gadījumu tādi vārdi kā lija, list, leca, léca, lekns tika izrunāti ar vidēji tumšu vai pat tumšu / I/, turpretī vārdos lapa, lāpa, laime da|a runātāju lieto vidēji gaišu / 1/. Pirms patskaṇiem / u /, / u /, / uo / fiksēts tumšais / l /: lupa, lük, logs.

Intervokālà pozicijā pirms / i /, / i /, / e /, / $\overline{\mathbf{e}} /$ galvenokārt dzirdams vidēji gaiša / / / variants: Vilis, mele, meli, kule, kūlis, pūlì. Arī pirms patskaṇiem /a/, / ā / vairākos gadījumos fiksēts / 1 / vidēji gaišs tembrs: silā, mala, sula.

Iepriekšstāvošie patskaṇi, liekas, neietekmē skaneña tembru. Tas īpaši redzams vārda beigu pozicijā, kur praktiski visos izrunas gadījumos skan "tumšs" vai "vidēji tumšs" variants: pil, mal, bail. 
Analīzes materiālā tika ietverti arī 3 värdi ar garu, stiepti ietonētu / I / intervokālā pozīcijāa: elle, balle, Ulla. Pārsvarā / I /, neraugoties uz tam sekojošā patskaṇa atšķirỉbäm, fiksēts kā vidēji tumšs.

Analīzei tika raudzīti arī vārdi ar / I / kā divlīdzskaṇu kopas otro elementu vārda sākumā. Skaṇu distribūcija latviešu valodā nosaka 8 šāda veida līdzskaṇu kopas. / 1 / tika izrunāts pirms dažādas kvalitātes patskaṇiem. To diktoru izrunā, kur iepriekšējos gadījumos tika konstatēts kăds "gaišais" / l / variants, līdzskaņu kopās [pl], [kl] un it īpaši [sl] pirms priekšèjās rindas patskaṇiem / l/ skan kā vidēji gaišs: plīst, plēs, plēsums, klïst, kläts, slïps, sleja, slieka.

[sl] fiksēts kā vidēji gaišs arī tad, ja pārējās līdzskaṇu kopas diktori izrunājuši ar tumšu / 1/, pie kam vidēji gaišs variants novērots arī pirms / a /, / $\mathbf{a} /$, /uo/: slapjšs, slāt, slota. Izteikti tumšs variants parādās līdzskaṇu kopā [ fl ]: flize, flote, flauta.

Dominējošais variants divlīdzskaṇu kopās ir vidēji tumšs, taču / l / tembrālā nokrāsa, šķiet, atkarīga no kopas pirmā elementa, sevišksi no tā piederỉbas pie balsīgiem vai nebalsīgiem līdzskaṇiem. Piem., pretstatā [ pl ] līdzskaṇu kopā [ bl ] visos gadījumos konstatēts / I / tumšais variants: blīkš, blēj, blašķe, blüzs.

Arī divās iespējamās trīslīdzskaṇu kopās / 1 / parādās kā vidēji tumšs vai tumšs: splīns, sklandu.

Vārda beigu pozīcijas ilustrācijai tika raudzīti vienzilbīgi vārdi ar līdzskaṇu kopu [lks] pēc / i / / / æ/, / a /: vilks, velks, malks. Šeit konstatēts tikai tumšais / //variants.

Pozīcijā starp līdzskaṇiem, kur / I / izrunāts kā zilbisks sonants (kupls, viegls, sekls, arkls), tas skan tumši vai vidēji tumši.

Vārda vidus pozīcijā, kur līdzskaṇu grupas bieži vien atdala zilbes robeža, netika novērotas / I / tembrālās atšķirības, piem., vārdos vil|ki vilk|me vai pulk|vedis, tāpat arī elp $\mid$ vads - skulp $\mid$ tors, zelt $\mid$ kalis - balt $\mid$ maize. / I/, atrazdamies 
zilbes beigâs aiz patskaṇa vai pirms sekojoša līdzskaṇa neatkarīgi no priekšā stāvošā patskaṇa, ir tumšs.

Salikteṇos ar divām līdzskaṇu kopām, kuru sastãvã ir / I /, vairumā gadījumu parādās zilbes pozīcijai atbilstošs skanena variants: vārdos peld/plêve, dubult/plisums pirmais / l/ skan tumši , otrais / / / - vidēji gaiši.

Agrāk veiktā skaneṇa / / / ilguma pētījums (Brēde, 1981) apliecina, ka vārda sākuma pozīijāa, kur / l / realizēts kā tumšais variants, tā ilgums pārsniedz gaišā varianta ilgumu (sonanta ilgums dots viena diktora izrunā):

tumšàis / / /

lukss $(90 \mathrm{~m} / \mathrm{sek})$

lūp $(100 \mathrm{~m} / \mathrm{sek})$

Lina $(100 \mathrm{~m} / \mathrm{sek})$

Tas pats vērojams arī intervokālā pozīcijā:

tumšais + I/

Paulis $(120 \mathrm{~m} / \mathrm{sek})$ gaišais / $1 /$

laime $(80 \mathrm{~m} / \mathrm{sek})$

lauž ( $75 \mathrm{~m} / \mathrm{sek})$

\section{Sïlis $(80 \mathrm{~m} / \mathrm{sek})$}

gaišais / $1 /$

pile $(80 \mathrm{~m} / \mathrm{sek})$

Ši tembra variantu saistỉba ar sonanta ilguma variantiem, protams, būtu vēl pētāma.

Lai gan informanti, kuru ieskaṇotais materiāls izmantots šajā analīzē, dzimuši dažădos Latvijas novados, vinu izrunā var saklausìt noteiktas tendences skaneṇa / l / tembrālo variantu lietojumā. Neraugoties uz palatālo patskaṇu klātbūtni, vairumā gadījumu / l / skan vidēji tumši vai tumši. Tikai runātāji no Limbažiem un Jelgavas sonantu / l / pirms priekšējās rindas patskaņiem izrunā gaiši. Citos gadījumos, raksturojot / I / šajās pozīcijās, piemērotāks liekas apzīmējums "vidēji gaišs"

Ja iepriekšminēto nesaista ar J.Endzelīna pētījumiem par atsevišķu izlokšņu īpatnībām, tad faktori, kuri, iespējams, ietekmē / / t tembru, būtu dalāmi intralingvistiskajos (piem., / l/ dentālā artikulācija, blakusesošo līdzskaṇu kvalitāte, īpaši to balsīgums vai nebalsīgums, sonantam sekojošā patskaṇa artikulācijas faktiskā atbilstība tradicionālajam iedalījumam priekšejjās, vidējās un paka|ējās rindas patskaṇos, $k \bar{a}$ arī zilbes intonācijas veids) un ekstralingvistiskajos. Šajā sakarībā varētu 
apsvērt jau agrāk izteikto pieñēmumu, ka tumšais / l / sācis dominēt krievu valodas ietekmē.

\section{Literatâra}

1. Ceplītis L., Miǩelsone A., Porīte T., Rag̀e S. (1995) Latviešu valodas pareizrakstïbas un pcreizrunas vārdnīca. $\mathrm{R}$.

2. Endzelīns J. (1938) Latviešu valodas skanas un formas. $R$.

3. Endzelīns J. (1951) Latviešu valodas gramatika. R.

4. Heffner R.M.S. (1949) General Phonetics. Madison: University of Wisconsin Press.

5. Jesperson O. (1926) Lehrbuch der Phonetik. Leipzig, Berlin: Teubner.

6. Jones D. (1956) An Outline of English Phonetics. Cambridge: Heffner.

7. Jones D. (1967) The Pronunciation of English. London, etc.: University Press.

8. Laua A. (1997) Latviešu literārās valodas fonētika. R.

9. Liepa E. (1968) Värda zilbju struktūra, veidi un robežas. LVU Zin.raksti, 86. sēj. R. 319. - 335.lpp.

10. Liepa E. (1970) Skanenu kvantitāte. LVU Zin. raksti, 98.sēj. R. 39. - 88.lpp.

11. Бреде М. (1981) Просодическая природа сонантов латышского языка (в сопоставлении с английским). Автореф. на соиск. степ, канд. филол. наук. Вильнюс.

12. Zālīte M. (1997) Apkārtne. R. 


\section{OBSERVATIONS ON VARIANTS OF THE SONORANT / / / IN LATVIAN Summary}

Sonorants occupy a special place in the phoneme system of language since according to their sonority they stand close to vowels.

The peculiarity of the sonorant / I / in Latvian is its tembral variants - the light (clear) $/ 1 /$ and the dark $/ 1 /$. The results obtained on the basis of an auditive analysis reveal that in most positions of the word the tembral colouring of the sonorant is closer to "dark" than to "light" With few exceptions / I / sounds dark or darkish even before front and central vowels not only in the final and medial, but also in the initial position of the word.

The tembral shades of / $1 /$ appear to depend on such intralinguistic factors as its dental articulation by a number of speakers, on the following vowel and its actual correspondence to the classification of vowels into front, central and back, the quality of the preceding consonant, esp. regarding the work of the vocal cords, and also the type of syllabic accent. Among extralinguistic factors that might explain an excessive use of the dark shade of / $1 /$ one can mention a probable influence of the Russian / l / that is traditionally described as darker than the Latvian one. 


\section{Genovaitė KAČIUŠKIENÉ}

\section{AKUSTINÉS DVIBALSIU PRIEGAIDŽIU YPATYBÉS ŚIAURÉS PANEVĖŽIŠKIŲ TARMĖJE: INSTRUMENTINIS TYRIMAS}

$\S 1$. Priegaidès lietuvių kalbos tarmèse geriausiai identifikuojamos dvigarsiuose dvibalsiuose ar mišriuosiuose dvigarsiuose [Zinkevičius, 1974]. Šiaurès panevèžiškių tarmès audiciniai tyrimai parodè, jog akūtiniu ir cirkumfleksiniu dvibalsiu priešprieša suvokiama beveik $100 \%$ [Kačiuškienè, 1984]. Cirkumfleksiniai dvibalsiai, auditorių nuomone, уга tariami lygiau, tolydžiau, labiau patęsiant garsus, o akūtiniai staigiau ir energingiau. Panašiai apibūdintos ir tarmès monoftongu priegaidès: akūtinius balsius auditoriai suvoke kaip šiurkštesnius, cirkumfleksinius - kaip švelnesnius, dainingesnius garsus [Kačiuškienè, 1985]. Kaip parodè instrumentinis tyrimas, balsių priegaides šiaurès panevéžiškiu tarméje (be kitu galimı požymių) skiria nevienodas pagrindinio tono kitimas. Akūto pagrindinio tono vidutinis staigumas apytikriai lygus $50 \%$, o cirkumflekso 33\%; akūtui būdingas pagrindinio tono netolydumas, cirkumfleksui - vientisumas bei tolydumas.

Gauti balsiu rezultatai paskatino išsamiau patyrinèti šiaurès panevèžiškių diftongu priegaides ir pažiūrèti, kokios akustinès ypatybès lemia ju diferenciaciją geriausiai identifikuojamoje pozicijoje.

\$2. Audiciniams ir instrumentiniams tyrimams buvo pasirinktos 6 žodžiu poros: trá.uke. 'tráukè' braũ.ke. 'braũkè', gn'á.uže. 'gniáužè' plaũ.ke. 'plaūkè', lá.uže. 'láužè': raũ.ke. 'raükè' Šias žodžių poras 3 diktoriai (2 vyrai ir 1 moteris) perskaite 400 kartų. Magnetofono irašu pagrindu buvo nufilmuotos oscilogramos' Oscilogramose matuota bendroji dvibalsio trukmé (ms), I ir II komponento trukmé (ms), intensyvumo ir pagrindinio tono viršūnès pasirodymo laikas

${ }^{1}$ [rašai daryti ir oscilogramos filmuotos Vilniaus universitete. 
(ms), absoliuti intensyvumo viršūnį reikšmè (dB), intensyvumo (dB) bei pagrindinio tono (pt) kitimo kreivè.

Gauti empiriniai duomenys buvo apdoroti ivairiais statistiniais metodais, kuriais naudojasi daugelis lietuviu kalbininky [Girdenis, 1974; Girdenis, Pupkis, 1974; Grumadiene, 1997 ir kt.] bei ivesti i ESM (programos sudarytojas A.Girdenis, programavimo kalba PL/1, programa "EGLE"). Mašinai buvo duota užduotis apskaičiuoti dvibalsių I ir II dalies intensyvumą ir pagrindini tona ju skirtuma, pradini minimuma $(\mathrm{dB} / \mathrm{pt})$, atstuma iki pradinio minimumo pradžios, galo, vidurio (ms), išvesti procenta, nubrèžti intensyvumo ir pagrindinio tono kitimo grafikus ir kt.

§3. Trukmé. Instrumentinis tyrimas parodè, jog akūtiniai dvibalsiai (skirtingai negu kitose lietuviu kalbos tarmèse [Girdenis, Kačiuškienè, 1988]) yra ilgesni už cirkumfleksinius (plg. [á.u] [āu.]= $340 \mathrm{ms:} 280 \mathrm{~ms}$; Stjūdento kriterijus $\mathbf{t}=17,8>$ $\left.\mathrm{t}_{001} 3,32, \mathrm{p}>99,9 \%\right)^{2}$ Aiškiai skiriasi ir kiti trukmès parametrai. Pavyzdžiui, i I dvibalsio dèmens trukmè (182,5 ms :114,0 ms, $t=27,85>t_{001} 3,32, p>99,9 \%$, Fišerio kriterijus $F=2,34>1,43$, p $>99 \%$.) rodo didesni akūtiniu dvibalsiu varijavima. Skiriasi ir II dèmens trukmè akūtinių dvibalsių II dèmuo yra trumpesnis negu cirkumfleksiniu $\left(158,0 \mathrm{~ms} \quad 166,7 \mathrm{~ms}, t=3,45>t_{001} 3,32\right.$, p $>99,9 \%$ ). Pastebèta ir tam tikru I dèmens bei bendrosios dvibalsio trukmès santykio skirtumy (akūtiniams dvibalsiams jis lygus $53 \%$, cirkumfleksiniams $41 \%, t=21,3>t_{001} 3,32$, $\mathrm{p}>99,9 \%$ ).

Intensyvumas. Dvibalsiu intensyvumo matavimai parodè, kad akūtiniu dvibalsių intensyvumo viršūnè pasirodo anksčiau negu cirkumfleksinių dvibalsių $(27,8 \%$ : $36,2 \%$, $\left.t=8,07>t_{001} 3,32 p>99,9 \%\right) .^{3}$

2 Panašu i šiaurès panevéžiskiu tarmès reiškini yra pastebejjusi L.Grumadienè, tyrinédama vilniečių dvibalsiu priegaidžių ypatybes [Grumadienè, 1997].

3 Panašius tyrimo rezultatus yra gavęs ir šios tarmès tyrinètojas K.Garšva [Garక̌va, 1982]. 
Intensyvumo viršūnès aukščio matavimai leidžia teigti, jog akūtiniuose dvibalsiuose ji yra aukštesnè negu cirkumfleksiniuose $\left(3,8 \mathrm{~dB} \quad 1,4 \mathrm{~dB}, \mathrm{t}=16,6>\mathrm{t}_{001} 3,32, \quad \mathrm{p}>\right.$ 99,9\%). Tai gali būti jtakojama to fakto, jog akūtiniuose dvibalsiuose balsis $a$ yra tariamas labai aiškiai, o cirkumfleksiniuose šiek tiek redukuotas, turintis o atspalvi [Pakerys, 1982].

Patyrinèjus dvibalsių viduriniosios dalies intensyvuma, matyti, jog šiek tiek intensyvesnè yra akūtinio dvibalsio vidurinioji dalis $(2,2 \mathrm{~dB} \quad 1,4 \mathrm{~dB})$. Tačiau rezultatų statistinis patikimumas tesiekia $\mathbf{8 0} \%$, nors Fišerio kriterijus aiškiai rodo didesni akūtinių dvibalsių varijavimą ( $F=4,61>1,43, p>99 \%)$.

Apdorojus empirinius duomenis skaičiavimo mašina gauta reikšmingu trukmès, pagrindinio tono ir intensyvumo koreliaciju.

Vidutines dvibalsiu trukmes ir vidutinio tono tyrimas leidžia teigti, jog šio tipo koreliacija yra labai stipri cirkumfleksiniuose dvibalsiuose $(0,6134>0,1931)$, akūtiniuose dvibalsiuose ji yra gerokai silpnesnè $(0,1174<0,2055)$.

Silpnos koreliacijos požymiu pastebèta tarp dvibalsių vidutinès trukmés ir vidutinio intensyvumo cirkumfleksiniuose dvibalsiuose ji yra lygi $0,1746<0,1931$, akūtiniuose dar silpnesnè - 0,0430<0,2055.

Labai stipri tyrinejjamų dvibalsiu intensyvumo ir pagrindinio tono koreliacija: cirkumfleksiniams dvibalsiams ji yra lygi 0,2587>0,0597, akūtiniams - 0,2230>0,0575.

Lyginant dvibalsiu vidutini intensyvuma ir pagrindini tonq pastebèta labai stipri akūtiniu dvibalsiu koreliacija $(0,357 \mid>0,2055)$, tik silpnos koreliacijos požymių galima užtikti cirkumfleksiniuose dvibalsiuose $(0,1490<0,1931)$.

Dvibalsių intensyvumo laużtiniu kreiviu procentu skirtumas irgi yra gana reikšmingas - u kriterijus viršija 99,9\% tikimybę (u kriterijus $=3,44>3,29$ ).

Tam tikru skirtumy̨ parodè ir intensyvumo bei pagrindinio tono aukščiausio ir žemiausio taško diapozony tyrimas. Cirkumfleksiniuose dvibalsiuose intensyvumo 
diapazonas lygus $9,1 \mathrm{~dB}$, o pagrindinio tono - 1,4 pt, akūtiniuose - atitinkamai $8,7 \mathrm{~dB}$ ir $1,5 \mathrm{pt}$.

Iš skaičiavimo mašinos pateiktu grafiku aiškiai matyti, jog cirkumfleksiniuose dvibalsiuose intensyvumas kinta tolygiau: akivaizdžiau mažèti ir kristi jis pradeda tik pačioje dvibalsio pabaigoje. Akūtiniц dvibalsiu atveju intensyvumas pradeda kristi maždaug nuo dvibalsio viduriniosios dalies (žr. 1 pav.).

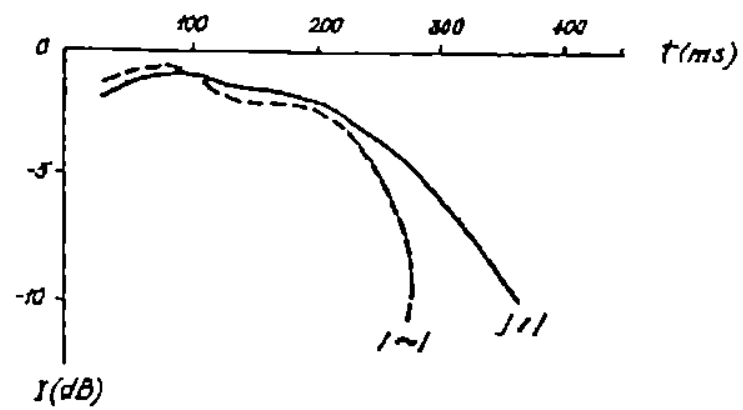

1 pav. Apibendrintos intensyvumo kreivés.

Pagrindinio tono kitimo kreive rodo, jog cirkumfleksinių dvibalsių tarimo pradžioje pagrindinis tonas šiek tiek krinta ir, tik pasiekęs maždaug garso viduri pakyla iki aukščiausio taško, po to palengva, "tiesia" linija pradeda žemèti. Akütinių dvibalsių pagrindinis tonas jau pirmoje garso dalyje pradeda kilti ir, maždaug ties jos viduriu pasiekęs viršūnę, ima kristi. Antrosios dvibalsio dalies pradžioje pagrindinis tonas dar šiek tiek pakyla ir "gaubta" linija pradeda leistis žemyn (žr.2 pav.).

§4. Šiaurès panevèžiškitł dvibalsil̨ [á.u] [aü.] instrumentinis tyrimas parode, kad akūtiniai dvibalsiai jvairiomis akustinèmis ypatybènis skiriasi nuo cirkumfleksiniq:

a) skirtingai negu kai kuriose kitose lietuviu kalbos tarmèse (ypač ženaičiı, pgl. [Girdenis, Kačiuškienè, 1988]) šiaurès panevéžiškių akūtiniai dvibalsiai yra ilgesni už atitinkamus cirkumfleksinius; 
b) akūtinių dvibalsių intensyvumo viršūnès pasirodo anksčiau ir yra aukštesnés negu cirkumfleksinių;

c) apibendrintos pagrindinio tono ir intensyvumo kreivès rodo stiprią šiı parametrų koreliacija;

d) gautieji rezultatai beveik iš esmès sutampa su monoftongy tyrimo rezultatais: ir vienu, ir kitu atveju minètos akustinès ypatybès vaidina svarbu vaidmeni identifikuojant tarmès ilguju skiemenı priegaides;

e) remiantis dvibalsiu [á.u] ir [aü.] tyrimu, galima teigti, jog veikiausiai tokios pat akustinès ypatybès lemia ir kitu šios tarmès ilgujų skiemenu, kurių pagrindą sudaro panašaus tipo dvibalsiai, priegaidžių skirtumus.

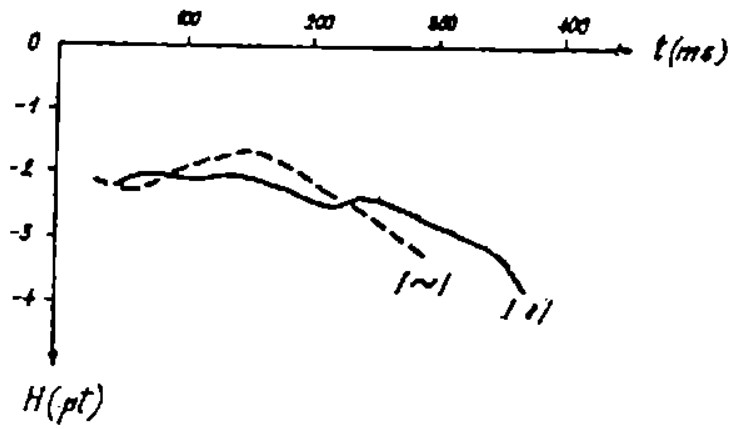

2 pav Apibendrintos pagrindinio tono kreivès.

\section{LITERATŪRA}

Garšva K. Svarbesnès šiaurès vakary panevėžiškil fonologijos ypatybès // Baltistica. Vilnius. 1982.T.18(1).

Girdenis A. Prozodinès priegaidžių ypatybès šiaurès žemaičių tarmeje (Trukmè, pagrindinis tonas, intensyvumas) // Eksperimentinè ir praktinè fonetika. Eksperimentinès fonetikos ir kalbos psichologijos koliokviumo medžiaga. Vilnius. 1974. T.6. 
Girdenis A., Kačiuškienè G. Šiaurès žemaičiu ir šiaurinių panevéžiškių dvibalsių priegaidès: gretinamoji akustinè analizè // Pedagoginių institutų studentų mokymo metodikos tobulinimas aukštosios mokyklos pertvarkymo salygomis (Mokslinèsmetodinès konferencijos ...pranešimu tezès). Siauliai. 1988.

Girdenis A. Pupkis A. Pietinių vakary aukštaičiu priegaidès (prozodiniai požymiai) // Eksperimentinè ir praktinè fonetika, min.veik.

Grumadienè L. Kokybinés vilniečių kalbos dvibalsiu priegaidžiu ypatybès // Pedagoginiu institutu ir t.t., min. veik.

Grumadienè L. Tarmiu priegaidžių atspindžiai miesto žmonių kalboje: eksperimentinis tyrimas // Linguistica Lettica. Rīga. 1997. T.1.

Kačiuškienè G. Fonologičeskaja sistema severopanevežskogo dialekta litovskogo jazyka: prosodija ir vokalizm (Dissertacija na soiskanije učenoj stepeni kandidata filologičeskich nauk). Vilnius. 1984.

Kačiuškienè G. Kuo gali skirtis šiauriniu panevéžiškių priegaides // Kalbotyra. Vilnius. 1985. T. 36(1).

Pakerys A. Lietuvių bendrinès kalbos prozodija. Vilnius. 1982.

Zinkevičius Z. Dèl akūto ir cirkumflekso skyrimo rytų Lietuvos tarmèse // Baltistica, Vilnius. 1974. T. 10 (1).

\section{ACOUSTIC PECULIARITIES OF DIPHTHONGS [áu] AND [aũ] IN NORTH PANEVÉŽYS REGION DIALECT} Summary

The oscilographic analysis of [áu] and [aũ] in North Panevėžys dialect proved that:

1) the diphtongs with the first stressed vowel (akūtas) are longer than the diphthongs with the stressed glide (cirkumfleksas)

2) It was recorded on the spectrogram that the frequency peaks of diphthongs with the first stressed vowel (akūtas) are visible 
earlier than that of diphthongs with the stressed glide (cirkumfleksas).

3) The frequency peaks of the diphthongs with the first stressed vowel (akūtas) are higher.

4) The correlation between the main tone and intensity is strong.

\section{ZIEMELPANEVĒŽAS IZLOKSNES DIVSKAN̦U lá.u/ UN /aũ./ AKUSTISKĀS İPATNĪBAS} Kopsavilkums

Divskaṇu /á.u/ un /aũ./ oscilogrāfiskā analīze parādīja, ka:

1) Zieme|panevēžas izloksnē akūtētie divskaṇi ir garāki par attiecīgajiem cirkūmflektētajiem divskaṇiem;

2) akutêto divskaṇu intensīvuma virsotnes parādās ātrāk nekā cirkūmflektēto divskaņu;

3) akutēto divskaṇu intensitātes virsotnes ir augstākas nekā cirkūmflektēto;

4) ir stipra pamattoṇa un intensīvuma korelācija;

5) iegūtie divskaṇu analīzes rezultāti Zieme|panevēžas izloksnē pềc būtỉbas sakrît ar monoftongu analīzes rezultātiem. 


\section{Daina NīTINA}

\section{VĀRDU IZVĒLES PRAGMATIKA}

Vārdu izvēli nosaka dažādi faktori. Pragmatiskā aspektā svarīgi ir tas, ko vēlamies panākt, kā vēlamies noskanot savu sarunu partneri, uzrunāto auditoriju vai lasītājus. Valoda ir nozīmīgs $k \vec{a}$ atsevišķa cilvēka, tā sabiedribas ietekmēšanas līdzeklis, un vienmēr ir svarīgi teikt pareizos, îstos vārdus ìstā vietā un laikā. Īpaši nozīmīgi tas, kā kas tiek nosaukts, ir politikă. Tieši to vai citu vārdu izvēle - nominācija - rāda un reizē arì rada viedokli, var ietekmēt tos daudzos, kam nav sava viedok|a vai kam uzskati ir nenoteikti, labili, var iespaidot tos, kas nezina vai īsti neizprot lietas būtību.

Ja kāds tiek pielīdzināts kaut kam tādam, kas tradicionāli atzīts par sliktu, vai pat pieminēts sakarā ar to, kas vairākumam asociējas ar ienaidnieka tēlu, uzreiz rodas vai var rasties negatīvs viedoklis. Savulaik, īpaši mūsu atmodas jeb auseklī̌̌u laika otrajā posmā, otrajā vilnī, pietika ieminēties - bijušais komunists un cilvēkā pašā jau radās iekšēja nedrošỉba, neērtîbas sajūta. Citos tas izraisīja piesardzỉbu, vēlmi norobežoties, attālināties. Visu izteica vārds, negatīvais tēls un mūsu priekšstati, ne cilvēks pats kā tāds, ne reālais nodarījums. Vai gluži otrādi - smalka, aizplīvurota, neskaidra izteiksme un atbilstošu vārdu izvēle palīdz slēpt vai retušēt realitāti. Piemēram, blēdības un mahinācijas saimniekošanā tiek apzīmētas ar vārdiem: pirmatnējā kapitāla uzkrāšana.

Spēcīgi attieksmes rādītāji un reizē ietekmêtājvārdi bija apzīmējumi: gaišie spēki, gaišie prāti. Lai mazinātu komunista vārda negatīvo nokrāsu, pasvītrotu to, ka ir komunisti, kas atbalsta tautas vēlmes un iet kopā ar tautu, atmodas sākumā tika radīti apzīmējumi: nacionālkomunisti, reformkomunisti. Vēlāk, kad ši nepieciešamỉba zuda un attieksme mainījās, vajadzēja radīt citu viedokli, proti, nepatiku pret turīgo kopsaimniecibu vadīājiem, neuzticēšanos tiem un neticību. Masu medijos parādījās jauns apzīmējums - sarkanie baroni, divkārši negatīvs 
vārdsavienojums: sarkanie, turklāt vēl baroni. Mazāk emocionāls, taču latviešu vairākuma apziñā tikai ar negatīvu attieksmi saistīts un līdz ar to negatīvu lādiṇu nesošs ir apzīmējums "ekssovjeti"

Politikā vārdu izvēli neapšaubāmi ietekmē un nosaka sabiedrībã valdošais noskaṇojums. Tāpēc politiḳa panākumu k̦īa ir prasme, varētu teikt gudríba uzminēt un nosaukt istos vārdus. Situācijai un tautas noskaṇojumam atbilstoši un līdz ar to veiksmīgi bijuši partiju nosaukumi: Tēvzemei un brïvibai, Latvijas celš, Saimnieks. To savulaik ir apliecinājuši arī Saeimas vēelěšanu rezultāti.

Politisko situāciju dažādi politiskie spēki atškirīgi vērtē, apzīmē ar vārdiem un reizē uzlādē. Tāpēc katrai partijai ir savi raksturīgi darbïbas balsta vārdi vai sauk|i, atslēgas vārdi vai vārdi orientieri. Par pieeju dažādību un politisku cīṇu liecina apgalvojumi - vārdi un vārdsavienojumi, kuri konkurē cits ar citu, ir pat pretrunīgi, izslēdz viens otru. Salīdzināsim, piemēram: "nacionālo attiecību harmonizācijas process" (LTF programma), "Latvija ir mūsu kopējās mäjas" (sauklis, ko izvirzīja Latvijas tautu forums un uztur spēkā "Līdztiesība") un gluži pretēji - "Latviju latviešiem!" (TB/LNNK) vai savukārt "nacionälais romantisms" (G.Ulmanis, 1997).

Jo problēma ir aktuālāka, sarežğìtāka un atšḳirīgāk to vērtē dažādi politiskie spēki, jo daudzveidīgāki ir izmantotie vārdi. Novads, ko atšķirīgi, pat diametrāli pretēji vērtē, uzlādē un apzīmē dažādi politiskie spēki, dažādi politiskie ideologi, ir sarežğîtās nacionālās un valodiskās attiecības, sarežg̀itāà nacionālā situācija Latvijā. Piemēram, politiķu runās un masu medijos sastopami apzīmējumi: Latvijas tauta latvijieši, pamatiedzìvotāji, pamattautība, citnacionālie (nelatviskie) iedzivotäji, cittautieši, cittautībnieki, Latvijas krievu kopiena, krievu valodā runājošie, krievvalodigie, nelatvieši, nelatviešu tautības iedzīvotāji, lìdzgājēejji, līdzgaitnieki, atbraucēji, iebraucēji, laimes meklētāji, nelegālie imigranti, kolonisti, civilokupanti u.c. 
Sava noteikta ideologiska vai politiski pragmatiska nozìme ir apzīmējumiem: nacionāli neviendabiga valsts, divkopienu valsts, paralèla sabiedrïba, vienkopienas sabiedrība; pilsonis, nepilsonis, ärpilsonis, ärvalstnieki.

Attieksmes paušana realizējas nominācijā vai nosaukuma maiñā, to dažādošanā un izraudzītajos epitetos, vārdos, kam piemīt emocionāli ekspresīva papildnozīme: goda vīi, svarīgi uzdevumi, valdìbas, arī lata stabilitäte vai: politiskie darboṇi, lokomotīvju un haizivju vilktās partijas. Piemēram, Eiropas Savienibas (ES) pretinieki pretēji Eiropiekritējiem tiek dēvēti par provinciāliem, tuvredzigiem un atpalikušiem.

Pretstatā pozitīvajam uzlādējumam latviska vide, latvietība, pamatnācija - pastāv negatīvā valodiskā izlādēšanās, kas politikā un propagandā ir kontrasta metodes un bipolärāa paṇēmiena realizẽšanās un izpaužas kā ienaidnieka tēla - ãrējā un iekšejā nosaukšana, apzīmēšana nikniem, nosodījuma pilniern epitetiem. Tā, tautas dusmās atmodas laikā apveltī PSRS šādiem vārdiem: bezkauniga kundzība, laupītājideolog̀ija, asinaina vara, nejēdzīga ekonomiskā sistēma, primitīva tehnologijia, absurda standartizācija, urbanizācijas gigantomānija, nedabiska, baiga industralizācija.

90.gados nopēlums un sašutums pakāpeniski vēršas pret pašu valsts negācijām, pilsoṇu kūtrumu, negodprātību un valdības neizdarībām, piem., rodas apzīmējums "elkoņu brivìiba" (V.Avotiņš). Situāciju un depresīvo noskaṇojumu sabiedrībā raksturo plaša šādu vārdu izmantošana: skandăls, nelikumības, haoss, cūcība, nejēdzìba, blēdības, rekets, jezga, izsaimniekošana, piesavināsanās, krāpšana, valsts radītie nabagi un valsts mantas izzadzēji, ņaudulīgie tautieši

Gan turīgo augstprātību, gan Latvijas sabiedrỉbas da|as bēdīgo stāvokli apliecina apzīmējumi: mazais cilvēks, renğgu èdāji, maznodrošinātie, trūkumcietēji, trūcigie, mazaizsargātie, mazturīgie, humpalas. Biežs šādu vārdu lietojums vai nu nomāc, rada pesimismu, vai gluži pretēji mudina mainīt situāciju. Lielu kāpinājumu - pozitīvo vai negatīvo uzlādēšanos - var 
panākt ar trīskāršu pastiprinājumu, ar trīskomponentu vārdu blīējumu, piemēram: visi apspiestie, s aspiestie un citādi varas dzirnavās $s$ a $m i c i t i$; valdĭba dzen tr $\bar{u} k u m \bar{a}$, post $\bar{a}$ un izm is um $\bar{a}$ (Vakara Ziṇas, 1997, turpmāk - VZ; retinājums mans - D.N.).

Asu kritiku izpelnās konkurējošās partijas, piemēram, valdošās liberāli konservatīvās politikas raksturošanai sociāldemokrāti lieto apzīmējumus: prettautiski mērksi, iznīcināts (iznīcināta rūpniecība un lauksaimniecība), sagrāve (sociālās politikas sagrāve).

Tāpat kā citviet pasaulē dažādos laikposmos un politiskās situācijās, arī Latvijā parādās politiḳi, politiskie spēki, kuru galvenais cīṇas panēmiens ir terors un agresija vārdos, politisko pretinieku nomelnošana, apvainošana, pat noķengāšana, piemēram, J.Z̄̄gerista partija paziņo, ka $80 \%$ Latvijas politiku ir bandīti. Savukārt P.Tabūns sev netīkamus politiķus un procesus apveltī tādiem vārdiem kā muldētava (Saeimas tribīne), muldētājs, absurdas lietas.

Valoda ir līdzeklis viedokla radīšanai un nostiprināšanai, palīgs noteiktu mērḳu sasniegšanā. Taču valoda rāda arī tautas noskaṇojumu, atklāj noteiktas sabiedrības dalas vairākuma vērtējumu un viedokli. Šajā sakarībā valodu mēdz salīdzināt ar seismogrāfu vai barometru ar jutīgu aparātu cilvēku attieksmes, sabiedrïbas noskaṇojuma noteikšanai. Tā kā Latvijāa par laimi nav zemestrīču un, cerams, to arī nebūs, izmantošu otro metaforisko apzīmējumu. Mēs varam uzdot jautājumu, ko dažādos laikposmos un atšķirīgās situācijās rāda latviešu valodas barometrs. Kādu laiku tas rāda saulainu un mierīgu vai apmākušos, vētrainu?

Atmodas laika, dziesmotās revolūcijas zīmes ir sajūsma un patoss, svinīgi cildenais stils, protesta un cerību vārdi "briviba", "neatkarība", "Latvija", "Tautas fronte", "gara spēks", kas radīja emocionālu eksploziju, vētras efektu: Latvija, cik skaists ir tavs värds! (1988).

Eiforiski idilliskais noskaņojums, mesiānisma gars sasaucas ar LTF programmatisko dokumentu deklaratīvi direk- 
tīvo stilu, kurā prevalē, piemēram, tādi verbi kā: uzskata, atbalsta, pieprasa, prasa, aicina. Piemēram, LTF pieprasa, lai valsts visiem republikas iedzīvotājiem nodrošina cilvēka cien̄igu dzīvi.

Solīti pa solîtim politika 80.gadu beigās realizējas kā piesardzība värdu izvēlē un nominācijā, piemēram, 1988.g., kad notikums bija pati uzdrīkstēšanās runāt, tiek diskutēts par samilzušām, sasāpējušām problēmām, par problëmu sastrēgumu, tiek nosodīti noklusējumi, puspatiesibas, baltie plankumi un pusperestroika. Ja 80.gadu beigās atmodu atbalstītāji komunisti tiek dēvēti par gaišajiem, progresīvajiem spēkiem, nacionātkomunistiem, tad jau 90.gadu vidū aizvien uzstājīgākas k|ūst balsis, kas iestājas par dekolonizāciju, dekomunizāciju un latviskas Latvijas atjaunošanu.

Saskarē ar realitāti idilliski jūsmīgais noskaṇojums un atbilstošais izteiksmes veids latviešu valodā pakāpeniski zũd, jo skaisto vārdu un lozungu laiks ir garām. Taču dažas partijas un politiķi, piemēram, Latvijas ce|š (LC), vēl līdz 1997.g. turas pie paaugstināta stila, pie virtuālās realitātes uzturēšanas: Mēs zinām celu. Ar paceltu galvu un latvisku stäju iesim kopā Latvijas celu! (LC, 1993) Esam pierādījuši, ka protam strādāt! (LC, 1997)

Realitāte un tautas noskaṇojums liek mainīt nostāju, un arī Latvijas cejam nākas atteikties no pašslavināšanās, no ekonomiskās augšupejas vīzijas cildināšanas un izvēlēties citus vārdus un sauk|us: Mēs piesakām karu trūkumam (LC kongress, 1997). Jau agrāk ekonomikas un saimnieciskās dzives prasības liek Latvijas celam izvēlēties par galvenajiem vārdus: pieredze un profesionalitāte. Šìm prasībām atbilst un līdz ar to gūst panākumus vēlēšanās demokrātiskă partija ar nosaukumu "Saimnieks" un sauklis: Esi saimnieks savā sētā, novadā, valstī! (1995). Situāciju mēgeina ekspluatēt arī citi politiskie spēki, atzīstot, "Mūsu stūrakmeṇi ir: vairāk darba - mazāk politikas" (Nacionālā progresa partija, 1997).

Vispārējā noskan̄ā iederas A.Škēes stingrā, atmaskojošā nostāja un raupjais, negatīvi kāpinātais, blīvētais izteiksmes veids. Lūk, daži šā politiķa lietotie vārdi un vārdsavienojumi: nabadzïba un zagšana, nekompetence, korupcija un izvirtusi 
morāle, viltus reformas, graujošā šoka terapija, iekšēji satrunējusī politiskā elite, tās patroni un minhauzeni, augstprātīga paśapmierinātība.

Pārmainu laiks Latvijā izpaužas kā jēdzienu "politika" un "politikis / politiki" izpratnes dinamika, to vērtējuma mainas atspogu|ošanās latviešu valodā. Atmodas laika, proti, 80.gadu beigu, politiki, LTF ideologi, tiek uztverti un izteikti valodā kā tautas varoņi, lîderi, ìsti valstsvīri, piem., nosaukti vārdos: gaišie präti, gaišo domu generatori.

90. gadu beigās attieksme pret politikiem, gluži pretēji, ir negatīva. To apliecina šādu vārdu izvēle un vārdsavienojumu izveide: tagadējie nobarotie politikāniskie nacionālradikāli (Neatkarīgā Rīta Avīze, 1996; turpmāk NRA), augstākās klases demagogs, parlamenta darboni, politiskie nelieši, politiskie kèmi, politikāni, politdaris, politiskie vājinieki, krēslu politiki, politisks äksts, politiskais tirgus, politiskais cirks, politisko spē]u nams.

Tiesu prāvas Latvijā tiek salīdzinātas ar komēdiju, farsu vai bufonādi, tiesu sistēma raksturota kā "valstiskā impotence" Starp citu, paralēli militārajai leksikai - fronte, karš, vārdu karš, karot - pēdējā laikā presē nav retums seksa terminologijas izmantošana: Un tad smalkā publika sagaidīja to, ko varētu saukt par orgasmu (NRA, 1996), sīka politiskā prostitūcija (Diena, 1997), Saeimas impotence (Diena, 1998). Sabiedríbas informētības līmeṇa nepietiekamïbu, pat zināmu atklātības farsu raksturo apzīmējumi un epiteti: skopos vārdos, slepus, dìvains, neskaidrs; mïklaina, skopa vai slepena informācija.

Gan dzīves skarbums un realitāte, gan demokratizācijas procesi veicina sarunvalodas vai pat vienkāršrunas vārdu izplatíbu, to iespiešanos politikas un propagandas valodā: ärpolitiskie klupieni, naudas piešprice, atskapēt uz komisijas sēdi, politiskie mutesbajāri, populistiska buldurēšana, pakampt miljonu, miljonu nokampēji, tautiski tusini, tusošanās, žuliki, cietumā "nolauzis" sešus gadus (par Rubiku, 1997), Šķēes "nokopšana" ('novākšana'; Diena, 1997), Latvija sākot Igauniju "iedzït" (NRA, 1997). 
Pazemināto vārdu izmantošana saistās ar tautas noskaņojumu, noteikta politika tēlu. Tā, A.Škēê, kas tautas apziñā asociējas ar dusmīga, stingra un prasīga politiķa tēlu, 1997.gada nogales intervijā "Dienai" vismaz 12 reizes lieto stiprus vārdus, piem.: Latvijas nākotnes politika nav jābūnē uz mēsliem - nu nav!

Būdams vārdisku vīziju meistars, pavisam citus vārdus izvēlas Valdis Birkavs: Latvijai piemît augsts dinamiskās attīstības potenciāls, ìsā laikā ir izdevies izveidot efektīvu sadarbibas modeli ar ES (1997). Presē viṇš un viña darbiba tiek raksturotà šādi: milziga optimisma pārpilns, sumina Latvijas ekonomiskos panākumus (Neatkarīgā Rīta Avīze).

Masu mediju un politiḳu valodā gadu gaitā aktivizējusies frazeologiska rakstura vārdsavienojumu, stabilu izteicienu lietošana, piem.: budžeta deķiti pavilkt uz savu pusi (Diena, 1996); drīzumā gaidāmas lielas ziepes, sākšoties ìstas ziepes (NRA, 1997); jäizskata tiesu sistēma, vai tur viss nav sagājis sviestā (A.Pante|ējevs, 1997); viena no kandidatūräm parādījusies pilnīgi no zila gaisa (NRA, 1997); ir mēg̀ināts kaut kā aizmālèt acis (Diena, 1997).

90. gadu otrajā pusēe pastiprinās humoristiskā, ironiskã un satīriskā stila iezīmes masu mediju valodā, aktivizējas ironiski satīrisks vērtējums un skatījums, ko izraisa vilšanās un ilūziju zušana un rāda šādi vārdi un vārdsavienojumi: nerentablie pensionāri, mūsu valsts varenie, daudzcietusī latvju tauta, lìdera viedie vārdi, Ministru prezidenta tradicionālais Jaungada sprediķis, pusnakts sludinātājs (VZ, 1998).

Nihilismu, vilšanos sevī, savos varoņos, par tradicionālăm uzskatītās vērtībās apliecina folklorismu un poētismu lietošana ironiskā, negatīvā nozīmē, piemēram: bālelini, nabaga bāleliṇi, istenie tautas bāleliņi šobrīd spekulē Polijā (Atmoda Atpūtai, 1991), latvju valstvīri, latvju dīksis, slavenais latvju politiskais orators (par O.Kostandu).

Tas saistās ar pēdējo gadu politikas valodai Latvijā raksturīgo vārdu polarizāciju, to aktualizāciju pretējā antonīmiskā nozīmē: dižvīrs Kostanda (P.Tabūna apzīmējums), 
varonīgā latvju armija, nācijas gläbēji (uzdoties par nācijas glābējiem - NRA, 1996), spiedis diżā priekšteča roku, mìlais vilku bars (VZ), dārgie aizgājēji (demisionējušie ministri), svēto Latvijas zemi izpārdot eskimosiem (VZ, 1996).

Politiķu un masu mediju valodā izplatīta klūst tradicionālā vārda tēla vai frazeologismu deformācija, to parodijas, piemēram: Mês rejam, bet Bütinges karavāna iet tâlāk (Diena, 1997), kaḳa lästi dzelzcela debesīs nekāpj (M.Vītols), lìdera zârciñus nevar tukšā palikt (A.Tarvids).

Metaforiskā izteiksme pašreiz visbiežāk pauž negatīvu attieksmi: politikas tīmeklī, likumdošanas caurumi, vaimanājoši

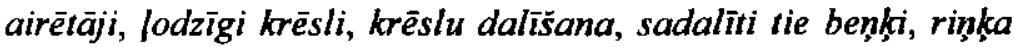
dancis ap krēsliem; ..vilki un läči atviezis savas ilknotäs rïkles. Piekläjības pēc teiksim, ka draudzìgā smaidā (VZ, 1996).

Tātad, kā rāda latviešu valodas barometrs, laiks pie mums pašreiz nav nekāds jaukais un saulainais. Taču cerams, ka kritumam sekos kāpums un latviešu valodā aizvien lielāku îpatsvaru gūs vārdi, kuri apzīmē cildināmas parādības, vārdi, kuri izteic un rada pozitivas emocijas.

\section{PRAGMATIK DER WORTAUSWAHL Zusammenfassung}

Wer kommuniziert, hat die Absicht, seinen Adressaten zu einer Handlung zu bewegen. Dabei werden Worte auch häufig zu Zwecken der Manipulation, Überredung, Suggestion und Überrumpelung benutzt. Die Sprache, der Wirkungskreis ihres magischen, suggestiven Vermögens, ihr Einflussniveau sind nicht nur ein Spiegel der Gesellschaft oder ein Messapparat (Seismograph, Barometer), der von der Lebensqualität zeugt, die Bewegungen der Gesellschaft fixiert, sondern ein bedeutendes Werkzeug, eine bewegende Kraft und Energie, die diese Veränderungen hervorrufen. Es handelt sich ausschlie $\beta$ lich um Originalbeiträge in lettischer Sprache. 


\section{Olga OZOLINA}

\section{DAŽI SISTĒMAS UN NORMAS MIJIEDARBĪBAS ATTİSTĪBAS ASPEKTI}

Valodas norma kā lingvistisko pētîjumu aktuāls aspekts vienmēr ir piesaistijjusi un turpina piesaistīt zinātnieku uzmanibu, neskatoties uz normas jēdziena dažu aspektu nepietiekamo izstrādātību (dialektiska pieeja normai, tās stabilitātes atzī̌sana, mainīgums, vēsturiskā nosacītība). Joprojām nav pietiekami izgaismotas dažas normas problēmas, kuras ir saistītas ar valodas līmeņu specifiku (piemèram, normas jautājumi sintaksē). Sarežgìti un neizpētîti ir palikuši arì jautājumi par valodas sistēmas, normas un uzusa korelāciju, par valodas normas iespējamiem tipiem, kā arī par normativitātes kritēriju noteikšanu. Maz ir arī tādu darbu, kas būtu veltīti valodas normas veidošanās un attīstības sākotnes izpētei, bet bez tiem galu galã nav iespējama dziḷa mūsdienu valodas normu izpratne. Taču nav šaubu, ka tieši valodas normu funkcionēšanas un attīstības vēsturisko likumsakarību izzināšana atsedz valodas procesu būtību, kuri ir tās pamatā un nosaka tās attīstības dinamiku, kā arī veicina aktuālu uzdevumu risināšanu valodas plānošanā, normēšanā un kodifikācijā.

Izejot no tā un pamatojoties uz darbien, kas veltîti franču valodas normu tapšanas un evolūcijas problēmām, šajā rakstā ir mēg̀inājums parādīt pētījamā jautājuma būtību un iepriekš minēto neatrisināto jautājumu izpētes pakāpi mūsdienu romāṇu valodniecīibā.

I. Normas jēdzienam parasti ir varianti atkarībā no valodas analīzes līmeņiem, tas ir, vai runa ir tieši par pašu valodu vai par valodas koncepcijām. Pirmajā gadījumă jārunā par politiku valodu jomā, par valodas standartizāciju, par tās normatīvu "regulěšanu", otrajā gadījumā jārunā par normas jēdzienu atkarībā no valodas teorētiskās koncepcijas. Turklāt valodu var aplūkot kā specifisku zīmju sistēmu starp citărn zīmju sistēmām. Tādā gadījumā normu attiecina uz kompetenci, 
priekšstatiem par "pareizumu" Savukārt, ja iziet no komunikatīvās lingvistikas pozīcijām, tad jāsastopas ar normu kā komunikatīvi valodniecisku fenomenu, kas atspoguḷo normas kā "elastīgas stabilitātes" (V.Mateziuss) funkcionēěanas raksturu un ietver tādu principu kā valodas normas un tās diferenciācijas vienotību atkarībā no valodas pielietojuma sfēras.

Priekšrocības šādai plašākai normas izpratnei ir skaidri redzamas tā lauj apvienot vienā veselā normas dažādus aspektus: normu kā tieši valodniecisku, stilistisku un kā valodas kultūras kategoriju. Valodas normas komunikatīvi valodnieciskais traktējums ir dzili dialektisks, jo pilnā mērā atspogujo normas kā divpusējas parādības būtību, kā objektīvā un subjektĩvā vienību.

Lìdz ar to lingvistisko aksiomātiku normas jautājumā var reducēt uz trim galvenajiem komponentiem: "objektīvă norma" (kā kolektīvi pieñemts lietojums), "nosakošā norma" (standarts), "subjektīvā norma" jeb individuālais lietojums (1).

2. Interesanta un perspektīva liekas psihosistemātiskā pieeja normas izpētei. Psihosistemātisko teoriju izstrādāja izcilais franču valodnieks G.Gijoms (Guillaume: 1883-1960). Tās galveno tēžu izmantošana normas teorijā veicināja, mūsuprāt, uzusa un normas jēdzienu skaidrāku diferenciāciju, darīja pieejamāku valodas normu evolūciju ne tikai reǵistrācijai, bet arī zinātniskai valodas plānošanai. Saskaṇā ar šo uzskatu norma ir funkcionāla rakstura jēdziens un atrodas ārpus rindas "valoda - runa" Veidojas triāde sistēma (valoda) - runa (uzuss) norma (L.Skre|ina) atšḳirī̉aă no triādes sistēma norma runa" (E.Coseriu).

Ja otrajā rindā norma tiek saprasta kā abstrakta shēma, kā vispārējs stereotips neatkarīgi no kopējās valodas potenciālajem un reālajiem variantiem, tad pirmajā rindā norma tiek traktēta kā viens no uzuālajiem tekstiem, kam piemît reglamentēšanas funkcijas un kas eksistē runājošā cilvēka apziṇā kā zināms etalons, kā "runas ideāls". Pie tam rindas elementu 
funkcijas sadalās sekojoši: sistēma (valoda) $\Rightarrow$ nosaka, runa (uzuss) $\Rightarrow$ izpilda, bet norma $\Rightarrow$ pielabo (2).

3. Franču valodas normu evolūcijas pētīšana |auj saskatīt cēloṇsakarîbu starp pārveidojumiem valodas sistēmā un izmaiṇām valodas normā.

Valodas normas evolūcija ir pakāpenisks pastāvošo normu izmaiṇu process atbilstoši valodas sistēmas elementu vai posmu evolūcijai. Tā ietver sevī trīs galvenās attīstības stadijas, kurām atbilst valodas normu trīs tipi (3):

1) potenciālā norma, kas ieḳauj dažādu runas reprezentāciju iespējas un kas atbilst jaunā elementa kā valodas sistēmas posma izveidei;

2) optatīvā norma, kuras pamatā ir priekšrokas došana tai vai citai runas reprezentācijai (vēlamā lietošana) un kas atbilst sistēmisko tendenču attīstībai;

3) imperatīvā norma, kuras pamatā ir vienu runas reprezentāciju noteikšana, bet citu aizliegšana (lietošanas $j \bar{a} b \bar{u} t \bar{i} b a)$, kas atbilst vienu valodas sistēmas elementu vai posmu nostiprināšanai un citu - novēršanai.

Tâdā veidā valodas normas evolūcija virzienā: iespējamais $\Rightarrow$ vēlamais $\Rightarrow$ jābūtība atbilst valodas sistēmas evolūcijai virzienā potence (nomināciju daudzums) $\Rightarrow$ tendence (priekšrokas došana tai vai citai formai) $\Rightarrow$ rezultäts (noteikšana lietot vienu no formäm).

Citiem vārdiem sakot, franču valodas vienību lietošanas normu evolūcija virzienā: potenciālā lietošanas norma $\Rightarrow$ optatīiva lietošanas norma $\Rightarrow$ imperatĩvā lietošanas norma atbilst valodas vienību strukturālās diferenciācijas posmiem virzienā: diferenciācijas potence $\Rightarrow$ diferenciācijas tendence $\Rightarrow$ diferenciācijas nostiprināšana (4).

Normas obligātums tātad ir tikai viens no normas izpausmes veidiem imperạtīvā norma, kas ir valodas sistematizācijas noslēdzošais posms (sistēmisko tendenču nostiprināšana), kamēr variabilitāte ir optatīvā un potenciālā norma, kas atrodas valodas stabilizācijas sākuma (valodas 
sistêmas veidošanās) posmā. Novērtējot dažādu valodas formu lietošanas pareizỉbu vai nepareizību, nedrikst, mūsuprāt, attiecināt to tikai uz kodificēto normu, tāpēc ka tas varētu traucêt valodas attīstību. Normas attīstība notiek, tieši pateicoties variantiem (5). Formu daudzveidība piemīt jebkurai literārai valodai un tās vai citas kategorijas variabilitāte jāvērtē nevis kā valodas trükums, bet gan kā tās eksistences forma. Izejot no tā, daži franču valodnieki pārstāv viedokli, ka norma nav jāuzskata par priekšrakstu kodeksu, kas lauj pareizi runāt šajā valodā. Viṇi noraida iespējamos normatīvos aizliegumus tāpēc, ka valoda parasti piejauj vairākus tă paša satura izteikšanas variantus. Tādēl, pēc viṇu uzskata, aizliegt kādu runas izteicienu nozīmē runātājam atṇemt izvēles tiesỉbas (6).

Atšķirỉbas, kas raksturīgas franču valodas runas un rakstu formai, apstiprina izplatītā normas traktējuma kritikas pamatotību. Izglītoto francūžu runa būtiski atškiras no viṇu rakstu valodas. Tas, kas tiek uzskatīts par nepareizu rakstītā tekstā, bieži ir attaisnojams runā.

4. Obligātuma piedēvēšana normai, normas un variabilitātes pretstatīšana nereti ir novedusi un noved pie apgalvojumiem, ka norma nepastāv vai ka tā ir nepietiekami izveidota tajā vai citā valodas vēstures periodā. Tajā pašă laikāa pēdējo gadu pētijumi liecina pretējo: normu pastāvēšana (normativitāte) ir pastãvīga un neatṇemama valodas ipašỉba, bez kuras valoda nevarētu pildīt savu pamatfunkciju būt par cilvēku savstarpējās sazināšanās, saprašanās un kopējās darbības līdzekli (7). Taču katram vēsturiskam laikmetam piemīt savas valodas normēšanas un kodifikācijas īpatnības. Ir jāšķir pirmsnacionālais un nacionālais periods.

Pirmsnacionālajā periodā ar tekstu salīdzinoši nelielo skaitu, kad vēl nenotiek grāmatu iespiešana un trūkst tekstu vispārējas izplatības, ir raksturīga lielāka formu daudzveidība (hronologiskie, sociālie, teritoriālie un funkcionāli stilistiskie varianti) nekā nacionālajā periodā. Tas tomēr nenozīmēe ka pirmsnacionālajām valodām nav raksturīgs valodas standarts. 
Jaunākajos lingvistiskajos pētījumos arvien biežāk tiek runāts par noteiktu valodas standartu pastāvēšanu, kas iziet ãrpus atsevišşu dialektu ietvariem vai kas piemīt virknei dialektu. Arī nacionālajam periodam ir raksturīga neviendabība: tã agrīnajā periodā nacionālajām literārajām valodām raksturīga mazāka normētības pakāpe nekā mūsdienu literārajām valodām (8).

Mūsdienu literārās valodas realizējas dažādu funkcionālo stilu tekstos rakstu un mutvārdu formā, tiek uzturētas ar masu saziṇas līdzek|u izvērstu tîklu. Taču arī ne visas mūsdienu literārās valodas tiek stingri normētas. Tā, piemēram, retoromāṇu literārajai valodai ir raksturīga neparasta variabilitāte, pat tā, ka tai nav stabilas lietošanas normas (9).

Norma ir vēsturisks jēdziens, kas mainās laika gaitā. Pie tam valodas normēšanas process ietver sevī stilistiskās un apzinātăs atlases principu. Stilistiskā atlase risinās pirms apzinātās un valodas agrīnās funkcionēšanas laikā kvantitatīvi ir pārsvarā. Citiem vārdiem sakot, pirmsnacionālajā periodā pārsvarā ir lietošanas potenciālās normas (nominācijas daudzveidība), kuras ir vērstas ne uz pastāvošās valodas sistēmas saglabāšanu, bet uz tās pārkārtošanu (3). Tāpēc noteikta valodas standarta eksistē̌̌ana, kurš piẹauj formu ievērojamu daudzveidību, liecina ne tik daudz par normētību, kā par tendenci uz viduslaiku literāro tekstu normēšanu (7). Bez tam, potenciālā norma, realizējoties stihiski, nepaklaujas zinātniskai plānošanai (3).

Nobeigumā varam izdarīt secinājumu, ka zinātniskajā plānošanā pirmām kārtām jāṇem vērā valodas evolūcijas konkrētais posms ar tam raksturīgajām normu tipu attiecībām. Valodniekam aktīvi jāpiedalās sabiedrības valodas gaumes veidošanā, izejot no sociālās un kultūras plānošanas vispārējiem un atsevišķiem uzdevumiem. Apzināta valodas normu tipu izmainīšana un plānošana, ņemot vērā sociālās un kultūras attīstības vajadzības, veido, mūsuprāt, vienu no galvenajiem uzdevumiem valodu politikas jomā. 


\section{BIBLIOGRĀFISKĀS ATSAUCES}

1. Guennier $N$. Linguistique et norme. - Français dans le monde. Paris, 1982., No 169., p 23.

2. Skrelina $L$. K voprosu o funkcionirovanii sistemi v situacii mnogojazičija. Romano-germanskije jaziki i dialekti jedinogo areala. Leningrad, 1977, 113.

3. Vlasov S. Evolucija norm francuzskogo sintaksisa: Avtoref. dis. kand. filol. nauk. Leningrad, 1986.

4. Ozolina $O$. Funkcionalno semantičeskije i strukturnije osobennosti odnokorennih obrazovanij $\mathrm{v}$ starofrancuzskom jazike. Leksičeskije i grammatičeskije innovacii. Rīga, LVU, 1982, 69.-79.

5. Edlička $A$. O pražskoj teorii literaturnogo jazika. Pražskij lingvističeskij kružok. Maskva, 1967, 553.

6. Langage et processus sociaux ( $\mathrm{Par}$ Marsellesi J.-B. et al. P.), Larousse, 1980., p. 52.

7. Volkova Z. Istoki francuzskogo literaturnogo jazika. Maskva, 1983, 23.-26. Kasatkin $A$. Očerki istorii literaturnogo italjanskogo jazika XVIII-XX vekov. Leningrad, 1976.

8. Budagov R.., Problemi izučenija romanskih literaturnih jazikov. Maskva, 1961, 6.

9. Borodina M., Sovremennij literaturnij retoromanskij jazik Šveicarii. Leningrad, 1964, 4. 


\section{ASPECTS ÉVOLUTIFS DU SYSTÈME AVEC LA NORME Résumé}

L'interprétation de la norme est étroitement liée au niveau d'analyse linguistique. S'il s'agit de la langue même, on est dans le domaine de la politique linguistique, de la standardisation d'une langue, de sa normalisation. Si l'on s'occupe des conceptions de langue, la définition de la norme dépend de la conception théorique de la langue. L'approche de la langue comme d'un système de signes parmi d'autres système de signes, rattache la norme à la compétence linguistique, aux notions de "correcte" et "grammatical" Mais la linguistique communicative met la norme et sa différenciation en dépendence de la sphère d'emploi de la langue.

Cette approche permet d'unir trois aspects différents de la norme: norme comme catégorie linguistique, norme comme catégorie systématique et norme comme catégorie culturelle, d'où "norme objective" (usage accepté par une communauté), "norme imposée" (standart) et "norme subjective" (usage individuel).

L'approche psycho-systématique de la norme, à la différence de la triade traditionnelle "système-norme-parole", introduit celle de "système (langue)-parole (usage)-norme" Les fonctions des éléments de ce système se partagent de la façon suivante: le système (langue) implique, la parole (usage) execute, la norme corrige.

L'évolution de la langue comprend trois étapes correspondant à trois types de normes: norme potencielle (emploi possible) > norme optative (emploi souhaitable) > norme impérative (emploi standart) qui reflètent les processus de différenciation structurale de langue: possibilité de différenciation > tendance à la différenciation $>$ renforcement de tendances systémiques. Il faut distinguer deux périodes de l'évolution: prénationale (riche en variantes) et nationale. 


\section{Gunta LOČMELE \\ LATVIEŠU REKLĀMAS VALODAS ATTĪSTİBAS TENDENCES: INFORMĀCIJAS KOMPRESIJA}

Laikā, kad mūsu dzīvē ienāk aizvien jaunas preces, pakalpojumi un ražošanas tehnoloǵijas, pieaugošu nozīmi iegūst reklāma. Strauji attīstās visas reklāmas jomas, tajā skaitā zinātniski tehniskā un politiskā reklāma, taču visstraujākās pārmaiṇas Latvijā vērojamas plaša patēriṇa preču un pakalpojumu reklāmā, kas arī izraudzìta par šî pêtījuma objektu.

Reklāmas valodas īpatnības jau sen saista ārzemju valodnieku interesi (Leech: 1972; Hamel: 1970; Antebi: 1968). Par reklāmas iezīmēm un tās ietekmi uz latviešu valodu domā arī Latvijas valodnieki (Zauberga: 1996; Veisbergs: 1997), taču detalizētu pētijjumu Latvijā š̄ valodas funkcionēšanas joma vēl nav guvusi.

Viena no pamattendencēm, kas raksturīga reklāmai kopumā, vai tā būtu latviešu, ang|u, vācu vai zviedru valodā, ir informācijas kompresija. Tā ir viena no valodas ekonomijas formām, kas izpaužas veidā, kādā autors kodē informāciju, ko gatavojas "pārraidīt" adresātam. Autors atlasa būtisko, atmetot visu nesvarīgo.

Informācijas kompresiju reklāmā nosaka virkne ekstralingvistisku faktoru. Pirmkārt, ir nepieciešams ekstralingvistisks konteksts. Kompresija ir iespējama tikai tādā gadījumā, ja adresātam jau ir nepieciešamās fona zināšanas, kas lauj tam saprast kodēto informāciju.

Otrkārt, kompresijas nepieciešamību nosaka pragmatiski faktori. Starp tiem minams tāds reklāmas komunikācijas traucējums kā adresāta nevēlēšanäs uztvert tam noraidīto informāciju.

Treškārt, informācijas kompresija tiek izmantota arī finansiālu apsvērumu dēl, jo pai reklāmas laukumu vai laiku ir jāmaksā. 
Ṇemot vēră to, cik būtiska ir informācijas kompresija reklāmai, interesanta šķiet informācijas kompresijas tendenču analīze latviešu reklāmā un tās îpatnību apskats dažādos reklāmas veidos: tranzītreklāmā, žurnālu reklāmā un televīzijas reklāmā. Salīdzinājumam tiks minēti arî piemēri no ang|u reklāmu tekstiem.

Lingvistiskajā literatūrā valodas ekonomijai atrodams divējāds skaidrojums: plaš̄ākā nozīmē tā izprotama saistīibā ar komunikācijas iedarbīgumu un ne vienmēr ietver kvantitatīvo aspektu valodas ìsas formas. Şaurākā nozīmē valodas ekonomijà saistīta ar isu valodas formu lietojumu.

Tranzītreklāmā kompresija nav atdalāma no kvantitātes. Reklāmas speciālisti, piemēram, amerikāṇi Kortlands Bovī un Viljams Arenss, uzskata, ka brīvdabas reklāmas plakātu teksts nedrīkstētu būt garāks par septiņiem vārdiem, pamatodami to ar cilvēka -uztveres ìpatnībām (Bovée, Arens: 506). Papētot tranzîtreklāmu uz Rīgas tramvajiem, jānonāk pie slēdziena, ka šis nosacījums ir gandrīz simtprocentīgi izpildīts. Garākajā reklāmas tekstā "Electrolux - visplaš̄āā sadzīves tehnikas izvēle mūsu veikalos Latvijā" astotais vārds "Latvijā" šīs ziemas apstāk|os gandrīz izdzisis, un nu tramvajs turpina ceju Rīgas ielās ar septiṇu vārdu garu tekstu uz sāniem.

Citā tranzītreklāmas piemērā kompresija ir loti izteikta, bet fona zināšanu trūkuma un kultūrvides atšķirību dē| varbūt latviešu cilvēkam ne līdz galam "atšifrējama" Zviedru alus Pripp's reklāmtramvaju rotā sauklis "Alus spēks ir garšā", kas tulkots, saīsinot anglisko saukli "The strength is in the taste. Pripp's Special Lager. The No.l selling beer in Sweden" (Spēks ir garšă. Gaišalus Pripp's Special Lager. Vispieprasītākais alus Zviedrijā.) Pripp's ir vieglākais alus un tāpēc vienīgais, ko Zviedrijā drīkst reklamēt. Tāpēc te ir ne tikai kvantitatīiva, bet arī semantiska kompresija, kuru "atšifrējot" potenciālajam klientam vajadzētu saprast - alus spēks ir garšā, nevis stiprumā.

Savukārt žurnālu reklāmā kvantitāte nav stilistisks faktors. Šādu secinājumu lauj izdarīt vairāku simtu žurnālu reklāmu virsrakstu analīze. Valodas ekonomija tajos tiek panākta ar 
informācijas kompresiju, kas vienlīdz izpaužas gan īsos, gan garos reklāmu virsrakstos. Žurnāla "Mans Mazais" reklāmas sludinājuma virsraksts "Rīgas Laikā": "Manai mammai un tētim patīku ne tikai es, bet vēl kāds mazais, - žurnāls Mans Mazais vērtīgs padomdevējs audzināšanā un laulības dzīvē" (Rīgas Laiks, 1997/2: 40) ir visai garš. Taču arī šeit vērojama viena no kompresijas formām - sintaktiskā. Reklāmas virsrakstā sakausēti divi teikumi: pirmā teikuma da|a tiek aprauta un, saskaṇā ar aktuālā dalījuma teoriju, otrā sakārtotā teikuma komponenta tēma ("žurnāls Mans Mazais") ir vienlaicīgi arī pirmās sakārtotā teikuma da|as rēma. Turklāt otrajā teikuma dajāa izlaists darbības vārds saitiṇas funkcijāa. Arī izpētītais anglu žurnālu reklāmu materiāls jauj secināt par valodas ekonomijas tendenču vērojuma pareizību - sekojošā automātisko atbildētāju reklāmas teksta virsrakstā ir 53 vārdi. Tas veidots $k \bar{a}$ informācija, ko reklāmas varonis ierunājis automātiskajā atbildētājā: "Hello. I'm not home right now. But my Sony Tele-Tracer knows exactly where l am. I've programmed it to automatically call me and play back every message I get as soon as I get it. So leave your name and number. l'll get back to you sooner than later. Buy" (Newsweek, 1986. Oct.: 9) (Hallo. Manis pašlaik nav mājās. Bet mans Sony atbildētājs ar meklētāju zina, kur esmu. Es to ieprogrammēju tā. lai tas pats piezvana un nodod man ziṇu, tikko tā sañemta. Atstājiet savu vārdu un uzvārdu. Piezvanīšu jums agrāk nekā vēlāk. Atā.). Lai arī virsrakstā izmantoti vairāki kompresijas veidi: fonētiskāa - darbības vārda - saitiṇas redukcija (forma $I ' m$ ), palīgdarbïbas vārdu redukcija (I've, I'll), sintaktiskā izlaists prievārds at (I'm not home), taču galvenā kompresijas izpausme ir precizajā vārdu un konstrukciju izvēlē ar mērḳi panākt maksimālu pragmatisku efektu.

Savukārt mazajos žurnālu reklāmas sludinājumos gan latviešu, gan ang|u valodā valodas ekonomija tiek izmantota tās šaurākajā nozīmēe.

Dažādu kompresijas veidu analīze rāda, ka ne visi no tiem latviešu reklāmā ir părstāvēti vienādi. Fonētiskā kompresija gandrīz nav sastopama ne tranzītreklāmā, ne žurnālu un pat ne 
televĩzijas reklāmu tekstos. Lai arī reklāmas varoṇi tiek izmantoti, tie runā pareizā literārā valodā, kura dažreiz skan pārāk iestudēti un samāksloti. Patiesībā reklāmās darbojošās personas runā rakstītā latviešu valodā. Arī dialektu izmantošana reklāmā ir pagaisusi līdz ar bēđīgi slavenā Toto kurjera galu, un "Die's vin 'zin" un līdzīgas fonētiskas redukcijas reklāmā šobrīd nav sastopamas. No vienas puses, tas liecina par valodas neelastību šādu fonētisku saīsinājumu veidošanā, no otras puses, parādās reklāmas autoru bailes no reklāmas valodas vulgarizēšanas, tāpēc pārmērīga eksperimentěšana ar valodu nenotiek:

Ang|u valodas īpatnỉbu dēl ši kompresijas forma anglu reklāmā ir visizplatītākā. Arī reklāmas autori ir izteikti drosmīgi tieši fonētiskās kompresijas jomā: kukainu iznīcināšanas līdzek|a reklāmai, piemēram, dots virsraksts "Waddayaneed?" (The Australian Women's Weekly, 1983, March: 241), kuru varētu atveidot kā "Kotatunugribi?" Bez fonētiskās šajā reklāmas virsrakstā vērojama arī sintaktiskā kompresija, jo arī visa teikuma struktūra ir sakausēta vienā vārdā.

Tieši sintaktiskāa kompresija latviešu rekiāmā izmantota visplašăk.

Te minami nominatīvteikumi: "Kvalitāte. Ātrums. Serviss" (Rigas Laiks. '97/2:72) - Kodak fotopreču reklāmas virsraksts.

Problēmu uzskaitijums eliptisku jautājuma teikumu formā ienes sekojošajā Coldrex zā|u reklāmā sarunvalodas nepiespiestîbu: "Temperatūra? Sāpes? Deguns ciet? Sāp kakls? C vitamīna trūkums?" (Santa. Dec./97, Nr.66: 61)

Plaši tiek izmantoti arī nepabeigti teikumi. Modes salona "Kolāža" reklāmas sludinājuma teksts ierauj mūs modes preču virpulī: "Trikotāža, mēteli, kleitas, rotas, cepures ballei, ikdienai... (Rigas Laiks, '97/2: 66), kas strauji apraujas. Te vērojama arī saiklu elipse, kas piešķir teikumam tempu.

Visai bieži tiek izlaisti arī darbïbas vārdi saitiņas, piemēram, "Pirmais šāgada "Santas" pielikums "Santas dārzs" tūlìt klāt!" (Rīgas Laiks, '97/2: 5I). 
Vērojama vairāku kompresijas veidu un līmeñu konverǵence, kā piemēram, žurnālā "Santa" publicētajā Samsung putek|usūcēju reklāmā (Santa, janv./98, Nr. 67: 2), kas veidota kā vienots informatīvs bloks. Reklāmas sludinājuma virsraksts un apakšvirsraksts ir saprotami tikai kopã ar attēlu - diviem izbiedētiem dalmāciešiem, no kuru mugurām jaudīga putek]usūcēja iedarbībā pazūd melnie plankumi. Reklāmas funkcionēšana, tās virsraksta, apakšvirsraksta un attēla savstarpējā saistība lauj uzskatīt reklāmas virsrakstu par valodas bloku' Valodas bloki tiek izmantoti, lai taupītu laiku (to diktē nepieciešamība momentā pārraidīt un uztvert informāciju) un vietu. Turklāt viena bloka sastāvda|a nav izprotama bez pārējām. Šinī piemērā metaforiskais virsraksts "SUGAS LEPNUMS" un apakšvirsraksts "GUDRS, PAKL̨AVIGS, JAUDĪGS..." saprotami tikai kopā ar attēlu. Tālākā apakšvirsraksta da]a kalpo kā paskaidrojums: "SAMSUNG MAZGABARITTU PUTEKLUU SŨCĒJI", taču arĩ tas bez attēla nebūtu saprotams, jo virsrakstā lietoto apzīmētāju virkne liek prognozēt apzīmējamā lietvārda lietojumu vienskaitlī, taču lietvārds "puteklusūcēji" pēkšṇi tiek lietots daudzskaitlī, turklāt nav īsti skaidrs, vai mazi gabarīti piemīt putek|iem vai to sūcējiem.

Loti interesantas tendences vērojamas leksiskăs kompresijas jomā. Tranzītreklămā uz tramvajiem tiek izmantots saplūdenis "Valiojogurts" Vārds jogurts, pats ienācis valodā kopā ar šo jauko produktu, tagad tiek iesaistīts arī vārddarināšanā.

Interesanta šajā jomā ir žurnālu reklāma. Sniegadēju reklāmas apakšvirsrakstā "“'Ski-Doo", tā ir visurcaurbraukšana" (FF, 1'97:10) izmantots labs okazionāls saplūdenis. Autors ir atturējies no tālākas saīsināšanas līdz viscaurbraukšanai, tā mēginot novērst lieku frivolitāti attieksmē pret valodu un, galvenokārt, pret reklamēto izstrādājumu.

\footnotetext{
' Par valodas blokiem raksta H. Štraumans un Džefrijs Līčs (Straumann, 1935: 21; Leech, 1972:90).
} 
Lieldienu preču un darinājumu reklāmas virsrakstam izmantots okazionālisms “Oltrauki” (Mans Mazais, 1997, Nr.3), izvairoties no divdomīgāka risinājuma "Olturi"

Šie vērojumi saskan ar Andreja Veisberga rakstīto par latviešu vārddarināšanas tendencēm un anglu valodas ietekmi uz valodas struktūrām. Saplūdeṇi ir perspektīvs vārddarināšanas pañēmiens reklāmas jomā (Veisbergs, 1997:280), to apstiprina minētie okazionālismi. Arī to, ka šāda veida saplūdeņu parādīšanās tiešām ir saistīta ar ang|u valodas ietekmi, pierāda tulkotie reklāmu teksti, kuros saplūdeṇi sastopami visbiežāk. GEMEY ' tonālo krēmu sērijas reklāmai dots virsraksts: "JAUNUMS! GEMEY NON STOP MAKE UP Ilgnoturīgs tonālais krēms" Saplūdenis ilgnoturīgs atšifrēts pirmajā reklāmas teksta teikumā, turklāt tas ir grafiski izcelts: "IIgstoši noturīgs tonālais krēms, kas neatstāj pēdas uz drēbēm." (Santa, Dec./97, Nr.66: II).

Gan anglu, gan latviešu reklāmā vērojama tendence izmantot semantisku kompresiju. Transportreklāmas sludinājumā "Latvija - Laimas zeme" kompresija ir arī semantiska, jo fabrikas nosaukums Laima šādā kontekstā asociējas ar laimi, un Latvija klūst par laimes un Laimas zemi, kas piešḳir šai reklāmai sevišķu emocionāli ekspresīvu nokrāsu.

Ir vērojami mēginājumi izdarīt semantiskus pārnesumus, kas labi paklaujas semantiskai kompresijai, jo tajos saglabājas arī to tradicionālā lietojuma konteksta sēmas jeb "nozīmes pēdas" Tā Pioneer audiosistēmas reklāmā autors raksta "Šāds aparāts būtiski nostiprinās tā īpašnieka prestižu draugu kompānijas acīs, pateicoties visurgājēja stilā veidotajam dizainam un iespējai ievietot 26 (!) kompaktdiskus vienlaikus." (FF, I'96: 9). Visurgājējs kalks no krievu "vezdehod" Visurgājēja automobila sēma varētu traucēt reklāmas adresātam uztvert šo reklāmu adekvāti, jo pārprotot varētu iedomāties, ka visurgājēja stils ir vizuāla līdzība šai zalajai mašīnai. Taču šī reklāmteksta autora risinājumā visurgājējs ir off-road atveidojums un šajā kontekstā apzīmē pārnēsājamu audioaparatūru. Savukārt automobila visurgājēja sēmai, pēc 
autora uzskatiem, vajadzētu pastiprināt domu par aparatūras jaudīgumu un universālumu.

Kādā citā reklāmā kalka izmantošana semantisko kompresiju pārspīlē, to vulgarizējot. Atstājot netulkotu anglisko "Joy Division" automobilu publicitātes raksta autors riskē pazaudēt semantisko kompresiju, tāpēc mēgina to kompensēt ar burtisku tulkojumu - kalku tekstā, liekot darinājumu pēdiñās un lìdz ar to pievēršot lasītāja uzmanību tam, ka šī vieta ir semantiski jutiga: "Amerikas legenda Chevrolet Corvette, kura tā kā nepiederētu pie vājākajiem pasaules automobiliem, - šî "prieka kantora" (no Joy Division) izdarību rezultātā pārvêrtusies par sudrabainu neitronbumbas dvīṇumāsu ar $480 \mathrm{ZS}$ dzinēja jaudu" (FF, 1'97: 9).

Interesanti, ka televizijas reklāmā pagaidām eksperimentu ar kompresiju ir mazāk nekā žurnālu reklāmā. Vērojama sintaktiskā un leksiskā kompresija - no leksiskajiem veidiem biežāk tiek izmantoti strupinājumi kā, piemēram, koka no kokakolas. Tas izskaidrojams ar to, ka reklāma adresēta masu auditorijai, tāpēc atkarî̉ā no produkta îpatnỉbām tai jāietekmē uz rīcību dažādi auditorijas segmenti. Jo jaunāka ir auditorija, jo vairāk jauninājumu tiek meklēti, savukārt konservatīvam pircējam adresētajos reklāmtekstos var nebūt ne vienas kompresijas izpausmes kā, piemēram, vienā no velas pulvera "Ariel" reklāmas versijām.

Vērojumi reklāmas jomā liecina, ka no vienkāršas reklāmas un visai primitīviem pirmajiem mēginājumiem eksperimentēt ar valodu mēs jau esam ierauti krāsainā konvergéjošu leksiski un sintaktiski semantisku struktūru virpulī, kas atdzīvina mūsu valodu un dzīvi, padarot to krāsaināku.

Kompresiju diktē straujais dzīves ritms, tãpēc dažreiz veiksmīgi izrādās tieši tie reklāmas teksti, kas no tās atsakās un izmanto atkārtojumu, paralēlas konstrukcijas, tādējādi radot mirk|a izjūtu, kad dzīve ir it kā apstājusies brīnuma gaidās. Tāda oāze atelpai pēc ikdienas amoka skrējiena ir reklāms teksts kāzu apgeerbu kolekcijai, kura autors veiksmigi atteicies ievërot visus šajā rakstā izklāstītos principus : 
"Tā var virpulot tikai prieks

Tā var uzlidot tikai mīlestîba

Tā var trakot tikai kaisle

Tā var slīdēt tikai maigums

Tā var apstāties tikai laiks

Ne issti uz zemes, ne isti gaisā ir sieviete, mīlestíbas nesta. Viña ir slidas attālumā no zemes..."

(Santa, janv./98, Nr.67: 53).

\section{Literatūra}

Antebi, M. (1968) The Art of Creative Advertising. New York, etc.: Reinhold.

Bovée, C.L. \& Arens, W.F. (1989) Contemporary Advertising. Homewood, Illinois: Richard D. Irwin, Inc.

Hamel, G. (1970) Zur Sprache ger Englischen Reklame. // Die Neueren Sprachen Number 5: 223-224.

Leech, G.N. (1972) English in Advertising. London: Longman. Straumann, H. (1935) Newspaper Headlines. A Study of Linguistic Method. London: George Allen \& Unwin, Ltd. Veisbergs, A. (1997) İsinātās vārddarināšanas formas latviešu valodā. // Linguistica Lettica 1, R., 271.-281.

Zauberga, I. (1996) Translation Norm in Advertisement Transfer. // A. Veisbergs (ed) Contastive and Applied Linguistics. Contrastive Studies V(Research papers, vol. 603), R., 50-63. 


\section{INFORMATION COMPRESSION AS A TENDENCY IN LATVIAN ADVERTISEMENT LANGUAGE Summary}

Western countries have a long history of consumer advertising. Latvian consumer advertising, reborn after Latvia embarked upon its road to democracy, demonstrates a rapid development which is often marked by anglophonic influence.

In order to reduce consumer reluctance, the English language of advertising makes use of specific language means economy of language via compression of information. Latvian advertising demonstrates an increasing tendency towards compression as well. There are differences and similarities of compression in the Latvian and the English languages of advertising. The adverts examined have revealed that in both languages we mainly deal with the concept of economy of language in its broad sense: brevity here is not a stylistic factor. Compression is mainly achieved by a precise choice of words and constructions.

The analysis has revealed that phonetic compression which is most widely used in English, is not used in the Latvian language of advertising at all. Syntactic compression is typical of both advertising languages. The lexical compression in the Latvian advertising shows the influence of English and provides new opportunities for word building. Different types of compression tend to converge in both languages of advertising.

Compression of information is regarded as a stylistic factor of the language of advertising. The tendency to compress information interacts with a tendency to plenitude. Compression can be regarded as a norm of the language of advertising, at the same time it should be admitted that the most effective advertisements in terms of consumer behaviour are often those which break the norms. 


\section{Giedrè CEPAITIENÉ KALBOS ETIKETO SITUACIJOS IR POETINE் FUNKCIJA}

Kalbejjimo akto tyrinètojai paprastai remiasi R.Jakobsono aprašytomis funkcijomis: referencine, apeliatyvine, ekspresyvine, poetine, fatine ir metakalbine (Leontjev 1974, 245-246; Girdenis 1995, 25-28 ir kt.). Kartais šios funkcijos savitai grupuojamos, iš esmès joms neprieštaraujant (Karaliūnas 1997). Kalbos etiketas - kalbinè mandagumo raiška. Ji retai esti individuali, daug dažniau formulinè, bendra visai ta kalba kalbančiai visuomenei. Drauge kalbos etiketo situacijos yra pokalbio, kalbèjimo akto situacijos, todè čia atpažjstamos ir svarbios visos jo funkcijos. Dažnai jos susipynę, tačiau konkrečiame kalbejjimo akte pastebimas kurios nors vyravimas, pvz., referencinè funkcija būdinga kvietimui, padékai, ekspresyvinè pagyrimui, komplimentui, apeliatyvinè ikalbinejimui, prašymui, fatinè pasisveikinimui, atsisveikinimui, kontakto palaikymui, metakalbinè pasitikslinimui, ar taip suprasta ir pan.

Poetinè funkcija atpažistama iš pasakymo kalbinés raiškos ypatumu. Ji išryškèja tose situacijose, kai kalbèjimo akte svarbiau ne tai, kas pasakoma, bet tai, kaip pasakoma. Kaip teigia B.Savukynas, poetinè funkcija esti tada, kai tekstas visų pirma orientuojamas i pati komunikata (Savukynas 1977, 17). V.Avrorinas, aptardamas kalbos ir kalbejjimo akto funkcijas, nurodè, jog poetine funkcija būdinga ne visiems kalbèjimo aktams, nes svarbiausias jos raiškos bruožas - specialūs stiliaus elementai (Avrorin 1975, 46). S.Karaliūnas pabrěžia, kad "poetiniy pasakymy bei dariniy ir poetinés kalbos apskritai esminiai požymiai yra netikètumas, nepaprastumas, išskirtinumas" (Karaliūnas 1997, 155). Taigi poetinei funkcijai būdinga speciali kalbos organizacija. Čia kalbos etiketo situaciju poetinès funkcijos pasireiškimu laikysime tas formules, kurioms būdingos ivairios stiliaus figūros ar sakinio rimas, jo ritmika. 
Apie tokias situacijas, būdingas latvių kalbai, pirmajame "Linguistica Lettica" tome rašo V.Emstsone. Ji gilinasi i komiškumo efektą ir jo kalbinę raišką Komiškumą, kaip pastebi straipsnio autoré, neretai sukelia speciali kalbos organizacija, ypač - jos ritmika. Tai iliustruojama ir kalbos etiketo situacijas atitinkančiais pavyzdžiais: Ko lüri? Ka nedabū ar dūri.; Gudra kā skudra. Kartais tokia poetine žaisme pasižymi visas pokalbis:
A: Nu ko tu!
B: Tuko!
A: Tuko ko?
B: Küko.

A: Tu ko, ko tu küko? (Ernstsone 1997, 81-85).

Kalbos etiketo poetinę funkciją labai dažnai atskleidžia smulkioji tautosaka. Tokios kalbos etiketo situacijas atitinkančios raiškos esama patarlèse, priežodžiuose, juokavimuose, keiksmuose. Poetiškumu ypač pasižymi patarlès. Kaip yra pastebèjęs K.Grigas, "jos dažnai pasižymi vaizdingumu, eilèdaros pradais ir visuomet sudaro sintaksiniu atžvilgiu išbaigtą sakini"' (Grigas 1968, 9). Neretai patarlèmis ir priežodžiais nusakomi ir paties etiketo reikalavimai, pvz.:

Keliskart pamanyk, tada pasakyk PP 201; Gerq peiksi neišpeiksi, bloga girsi - neišgirsi ST 215 Erž; Geriau patylèti, negu niekai kalbèti PP $111 \mathrm{Rk}$; Kas giria kitam skiria, kas peikia - sau teikia ST 275; Giriamas vaikas visuomet paikas PP $149 \mathrm{Jz}$; Is savo burnos ant savo galvos (kai pats save apkalba) PP 354 An; Prieš didesni bük mažesnis PP 129 Jnš; Kas save giria, ta Perkūnas spiria PP 45 Inš; Pirma padirbk, paskui pagirk PP 48 Jnš; Lengva pasakyti, bet nepadaryti PP 45 Jnš; Atmink, mano vaike: daug kalbèt nereikia PP 166 Ds; Blogos ausys gero żodžio neklauso PP 171; Daug žinok, maž bylok PP 173; Dzirdi daudz, runā maz Kok 176 Cēsis; Gera gudriai kalbèti, bet gudriau nutylèti PP 179 Ps; llgas liežuvis vaidus gimdo PP 113 Mrj; Mutē medus, sirdĭ ledus Kok 230 Tukums; Balsu saldus, darbais kartus KM 2654 Lzd; Priekšä vada, no 
pakalas bada Kok 230 Jelgava; Akyse kaip šilkas, už akiu kaip vilkas PP 105 Vs ir pan.

I pastaruosius panašūs ivairūs palinkèjimai, pvz: Duok, Dieve, viskq žinoti, bet ne viska byloti KM 7048 Ps; Tegul Dievas padeda, kas gerai pradeda PP 53 Ps; Dieve, duok iš pono ubagq, ne iš ubago ponq PP 72 Ds; Duok, Dieve, mažu gimti, o dideliu augti PP 89 Ds; Dèkui, Dieve, - duktè ištekejo, neduok, Dieve, - sūnus nori żenytis PP 147 An; Rugiu miežiu, avižu ir daug daug vaiku mažu (jaunavedžiams) Snt.

Neretai patarlès pabrèžia, kad būtina mandagiai kalbèti, t.y. laikytis etiketo reikalavimu, pvz.: Ar su ta paćia burna ir valgai? (sakoma negražiai kalbančiam) LKŽ Gs; Regi, kokia burna - sarmata su geru svietu sueiti (negražiai kalba) LKŽ Tvr; Išsiplauk burnq! (gražiau kalbèk) LKZ̆ Krkl; Iš tos pačios burnos ir šilta, ir šalta LKŽ S.Dauk; Keiksmas pro burnq išeina, pro nosi pareina PP 201; Pikta żodi visi girdi PP 225; Žodis skriaudžia, žodis ir glaudžia PP 244; Blogu kalbu nedidink: jos pačios auga $\mathrm{PP} 171$; Dèl ilgo liežuvio ne vienam dantys išgriuvo PP 109 Šl; Geras żodis i blogas ausis neina PP 180 Jnš; Keikiasi ne supykęs - keikiasi išdykęs PP 96; Kaip palinkessi, taip tau atlinkes PP 116 Trg. Tik retkarčiais patarlès atspindi kiek kitoki požiūii i kalbos etiketą, mandagaus kalbejjimo būtinybę. Viena kita patarlè parodo nuostatas, kad bendravimo normos néra gyvenime svarbüs dalykai, pvz.: Mandagumu valgio neuždarysi PP 209; Su žodžiais maišelio neprikrausi PP 51; Žodis galvos nepramuš PP 244.

Poetinè funkcija būdinga ivairioms kalbos etiketo situacijoms. Neretai tokia kalba būna šmaikšti, kartais kiek pašiepianti. Paprastai ji vartojama tada, kai abu kalbejjimo akto dalyviai gerai vienas kita pažista. Ji ypač būdinga vaikų kalbai, neretai jeina i vaiku folkloro rinkinius.

Sveikinimasis: Labq dienq. Su vištiena Snt;: Kaip tavo pavardè? - Kaip auksinè raidè. - Kaip tavo vardas? - Kaip auksinis kardas ST 845 Jnš;-Kaip tavo pavardè? Mano žila pabarzdè ST 845 Šd; -Kaip vardas? -Rankovè. -Kaip pavardè?Issimové ST $845 \mathrm{Rm}$. 
Tokie pokalbių fragmentai būdingi anaiptol ne vien vaiku kalbai, plg. Kas čia? Kasčius su kašutèm (kai savas neatpažjsta) Snt; -Sveiki gyvi. - Sveiki, tik nelabai gyvi ST 864 Grł̌; -Sveikas! Bobos vaikas! ST $864 \mathrm{Kp}$; Gerq dienq! Prašom kas dienq! ST 864; Kas vakars "Labs vakars"(apie dažnai besilankanti) Şk; apie nesisveikinanti sakoma: Ir kiaule pro kiaulę eidama sukriuksi PP $114 \mathrm{Jnšs;-Ar} \mathrm{nematei} \mathrm{kiaules} \mathrm{su}$ zvaneliu?- Mačiau, ten pagal medini akmenq knise, knise ir nubego ST 864; $\dot{E}$, ar nematei kiaulès su skambaliukais? ST 863 Škn; Ar nematei margos kumeles? Šk; Praejo, né čiu čiu, nè še lauk Šk.

Savitai sutinkami i duris pabeldę ir užeiti norintys žmonès: - Ar galima? -Prašom pro kamina Nm; -Ar galima? Prašom pro śali Šk; - Prašom per aplinkui Snt: - Prašom per naujqsias $\mathrm{Nm}$; Prašom per stiklines Śk; Praśom, meldžiam, liepiam neit Snt. Pastarasis posakis vartojamas tada, kai dažnai i duris beldžiasi kieme žaidžiantys vaikai arba pro langa buvo matyti, kas ateina.

Jei atėjęs žmogus buvo prieš tai paminètas, sakoma: Vilkq mini vilkas čia PP $439 \mathrm{Rm}$. Kai atsilanko seniai nebuvęs, juokaujama Svečias nebuvèlis -- /Duokit sūrio supuvelio ST 837; O, svečias nebuvelis. Reiks pečius pabučiuoti ST 837 Kkt. Kai atèjęs žmogus randa besijuokiančius, jis pasišaipo Tai juokeliu iki keliu Snt.

Pasiteiravus -Kaip gyvenat? neretai atsakoma Gražiai (gerai) gyvenam, tvoras (šiaudais) kūrenam, dūmelis rüksta, nieko netrūksta Snt. Kai klausiama - Kiek laiko?, galima išgirsti keleriopus šmaikščius atsakymus: Kiek pakelia, tiek ir laiko ST $852 \mathrm{Pn}$; -Kiek nutverè, tiek ir laiko ST 852 Žd; Viens pjauna, du laiko ST 852 Žd; arba Dičkis už kampo mažiuka tampo Snt. Pasišaipoma ir tada, kai nè vienas iš pašnekovy nežino, kaip atsakyti i rūpimą klausimą Klausk manęs, $o$ aš tovęes Snt.

Dèkojimas: -Ačiü. - Pabučiuok pečiu ST $860 \mathrm{Krž;-} \mathrm{Ačiū.}$

Pabučiuok savo pačiq tik svetimos negriebk ir $i$ mergas nežiūrèk; - Ačiū. - Su ačiū neatkiši (neužkiši) Snt; -Ačiūu. - Su ačiū neatbūsi! ST $860 \mathrm{Kkt}$; -Dékui! - Pjauk karvę - bus blèku ST 
$860 \mathrm{Pn}$; Dekui sveika gatavojus, / Mano pilvq retovojus./ Jeigu bütum tu numirus, / Kita būt geriau išvirus ST 861 Všk.

Prašymas: Parodyk... Parodyms piniga kaštuoja Snt; Duok tabako. - Kieno talka, to ir tabaks Šk; -Duok sürio--Apvirsk külio ST 849; Duok pyrago.- Gausi ožio raga ST 849 Žd. -Duok ragaišio.- Ragaišsio da bobutè neimaišé ST 849.

Raminimas, guodimas. Neretai guodžiami vaikai. Kai iškrenta pieninis dantis, guodžiama buriant: $-T e$, pele, kaulini. duok man geležini Snt. Kai raminamas verkiantis vaikas sakoma taip: -Kiau, kiau, kiau, ar aš nesakiau Snt. Guodžiami ir sunkiai sergantys ligoniai. Pradejusiam taisytis tariama: $-\mathrm{Ka}$ tik tu tai giltinelei pažadejjai, kad ant šio svieto dar paliko? Ssr.

Yra patarliı̨, skirtı̨ nesusikalbantiems pašnekovams, pvz.: Susikalbejo kaip žqsis su kiaule PP 419 Al; Rumā ka cūka ar zosi Kok 244 Liepāja; Susikalbejo kaip šuo su żasinu PP 419; Kits kita suprato kaip kiaulè žasi PP 374; Tu kalbi apie akèčias, o aš apie vežécias ST 322 Švnč; Vienas apie ratus, kitas apie batus Snt; Viens runā par vēju, otrs par dzirnavām Kok 244 Ryga.

Pagyrūnas taip pašiepiamas: -Eik balu degti ir su pakulom gesyti Šk; Giriasi kaip bajoras su popieriais PP 75 Šd; Giriasi kaip šlektelè rudeni PP 75. Jei giriamasi ilgai nešiojamais drabužjais, atkertama: -Šitos kelnés tévu tevo, jos nebijo jokio véjo Snt.

Nekantriam, skubançiam i namus sakoma: Dar koju nesušilai, o jau skubi ST $836 \mathrm{Kp}$; Gal mieliu atejai, kad nesisedi Šk; Kiba ka ikepęs, kad taip skubini Snt; Ar kiaušini ¿kepei, kad teip skubini? LKŽ Lkš; Namai ne kiškis - nepabègs PP 387 Psv; Namai ne lašiniai, kates nesues ST $255 \mathrm{Kt}$; Namai - ne šakaliai, nesudegs ST 255. Pasišaipoma ir iš ilgai neišsiruošiančio žmogaus Mirksi, o ne kirksi Grš.

Poetine funkcija pasižymi ir keiksmai, ypač prakeiksmai. Ju poetiškumą stiprina su magija, senaisiais tikèjimais susijusių žodžiụ vartosena. Keiksmą siunčiantis ir ji girdintis žmogus tarsi itiki žodžjo sugebẻjimu pavirsti ivardytu veiksmu, pvz.: Kad tave Dievaitis užmuštu! ST 870; $O$ kad tave 
dundulis užmušrtu! ST $870 \mathrm{Rm}$; Kad tave perkūnas vidury dienos trenktu! ST 871; Imk tave devyni velniai! ST 871; Eik tu i pekla molio minti! ST $876 \mathrm{Rm}$ ir pan.

Šiose kalbos etiketo formulèse poetinę funkcija atlieka ivairios stilistinès figūros. Kaip teigia K.Župerka, stiliaus figūros yra ypatingas, nestandartinis kalbinès raiškos būdas, jos dažniausiai vartojamos grožinèje literatūroje (Župerka 1997 57). Dalis šių figūru būdingos ir vaizdingai šnekamajai kalbai, iš tokios kalbos ir gimè patarlès, priežodžiai, frazeologizmai. Kalbos etiketo tematiką atspindinčioje smulkiojoje tautosakoje esama ivairių lygmenų stiliaus figūru: semantinių, darybiniu̧, sintaksinių, fonetiniu.

Bene gausiausiai iš semantiniu figūru patarlèse vartojama metonimija. Kalbos etiketui svarbiose situacijose neretai ivertinamas žmogaus kalbèjimo būdas, jo ryšys su protavimu. Todèl gana dažnai patarlèse galima pastebèti metonimiška žodžio liežuvis vartoseną, pvz.: Liežzvis be peilio papjauna PP 207; Kieno ilgas liežuvis, to protas trumpas PP 97; Kvailo liežuvis galvos nesiklausia PP 99; Liežuvis żmogu pakaria, lieżuvis ir paleidżia PP $99 \mathrm{Al}$; Lieżuvis be kaulo: kur siunti, ten eina PP 99 Ms; llgas lieżzvis vaidus gimdo PP $113 \mathrm{Mrj}$. Čia žodžiui liežuvis suteikiama "kalbos, gebèjimo kalbèti" reikšmè. Kartais patarlèse metonimiškai pavartojamas žodis galva, pvz.: Kokia galva, tokia ir kalba PP 97 Svlk; Kas galvoje, tas ir kalboje PP 95 Trg; Galva visq żmogu vedžioja PP 89 Rk. Šiuose pavyzdžiuose žodis galva reiškia "prota, išmanyma, sugebẻjimą mąstyti"

Patarlese ir kituose vaizdinguose posakiuose, apibūdinančiuose ivairias kalbos etiketo situacijas, esama ivairiu metaforos atmainu. Kartais čia pavartojama hiperbolè: Geras ir żodzio klauso, pikto ir lazda neatitaiso PP 89 Šll; Boba senyn, liežuvis ilgyn PP 89 Btg; Piktq žodi visi girdi PP 225 ir pan. Neretai čia esama ironijos. Jai būdingas netikètumas, priešing 4 dalyku sugretinimas, pvz.: Žodžiu ažuolus varto, darbu ir skiedros nepakelia (apie pagyrūna) PP 444; Aukščiau bambos neiššoksi (apie besididžiuojanti) PP 314 Up; Kytras ant kytraus, 
šŭdas ant lytaus (apie besigiriančius) Ssr. Profesorius J.Pikčilingis, skatindamas mokytojus lituanistus didesnį dèmesi skirti smulkiajai tautosakai, yra pateikęs dar tokių kalbos etiketo situacijas parodančiu ironijos pavyzdžių: Klausyk ausim. ne avižom; Kur bivai, kai protq dalijo?; Rytoj kurčiu jomarks; Rytoj kurčius saudys; Nuvažiavo kaip su burokais i malūnq; Nivažiavo kaip nuo Striūpı tilto (apie nusikalbanti) ir pan. (Pikčilingis 1992 78-79).

Labai retai kalbos etiketo situacijas apibūdinančiose patarlèse galima rasti jasmeninimą rodančiu pavyzdžiu. Jie paprastai esti susiję su mitologiniu būtybiu ivardijimu, pvz.: $K q$ tik tu tai Giltinèlei pažadejai, kad ant šio svieto dar paliko? Ssr; Kas save giria, tq Perkūnas spiria PP 45 Jnš. Kartais galima pastebèti ir oksimorono pavyzdžiu, kai vienoje frazeje pateikiami semantiškai tarsi nesuderinami žodžiai, pvz: $N u$, kirviai, kilkit iš vandens (sakoma neskubantiems pakilti nuo stalo) Snt.

Darybinių figūrụ nèra gausu, jos būdingos posakiams, apibūdinantiems snaudalius ar miegoti susiruošusius asmenis, pvz.: Jau keliausim i Miegonis pas panaitę paduškaitę Alz; Eik pas Püki $i$ Miknaičius ST 850 Grš; Eisim i Miknaičius pas Plunksniu Snt; Žiovelènas Kirkliūčia ima; Migšys perša užkuriom. Visi čia pavartoti tikriniai daiktavardžiai - situaciniai žodžiai. Kartais situaciniai žodžiai atspindi ir kitus santykius. Prašant paskolinti ("pažičyti") juokaujama Žičkas mirè,/ Žičkienè nebežičija,/ Žičkiukai dar mažiukai ST 842, o prašančiam paragauti atsakoma Paragavičius mirè. Mirsi ir tu ST 843 Mrj.

Kartais posakio poetiškumas kuriamas ivairiomis homoformomis ar panašiu formu saskambiais, primenančiais kalambūrus. Pavyzdžiui, pasakius $D a(r)$ lyja atsakoma Jei dalija, eik, ir tau duos ST $844 \mathrm{Pn}$. I ispèjimą Iš kelio atšaunama Atvažiuoja Kaškelio ST $844 \mathrm{Sn}$, i klausima Ka darai? atsakoma Kadarai, kadarai ST 851 Vlkv. Neretai tarsi žaidžiama tapačiu formu reikšmèmis, pvz.: -Pagavo vagi. Vagi reikia i siena ikalti, bus ant ko pančius sukti ST 852 Grš; -Kiek laiko? - Kiek 
nutverè, tiek ir laiko ST 852 Žd; Ne tavo kiškis, ne tu ir kiškis Žvr; Tai juokeliu iki keliu Snt ir kt.

lš sintaksinių figūry minètini kreipiniai, retoriniai klausimai, sintaksinis paralelizmas, elipsè. Sintaksinès figūros paprastai susijusios ir su sakinio rimu, kuri neretai lydi fonetinès figüros (aliteracija, asonansas). Sintaksines figūras iliustruoja tokie pavyzdžiai:

Kreipiniai. Paprastai pašaipiai kreipiamasi ivairiai rimuojant vardus: Elžbiet, jau saulè popiet ST 829; Juozai garbüzai, duok miltu buzai ST $829 \mathrm{Krn}$; Mare, pagiry aria ST 830 Vlkv; Mikai, Mikai, ar visi indikai? ST $831 \mathrm{Krn} ;$ Petrai, Petrai, kada bus geri metai? Snt.

Retoriniai klausimai paprastai esti tada, kai adresantas jau klausdamas pateikia teigiama (ar neigiama) atsakyma. Kartais tokie klausimai pavartojami ir tam tikrose kalbos etiketo situacijose, pvz., Kas kels šuniui uodegq, kad ne pats? PP 371 (besigiriančiam). Retkarčiais pavartojami ir tokie retoriniai klausimai, kuriais norima tik atkreipti pašnekovo dèmesi pvz., Ar nematei kiaules su zvaneliu? ST 864 ir pan.

I retorinius klausimus panašios klausimu-atsakymu formulès, kur ir klausdami, ir atsakydami pašnekovai tarsi žaidžia kalbos priemonèmis, iš tiesu net nesitikèdami kokios nors informacijos. Tokiu pokalbiu pavyzdys - jau minèti vaiku žaidimai, teiraujantis vardo ar pavardès. Kiek kitokie esti juokaujami atsakymai, kai situaciją valdo i klausimą atsakantis žmogus. Neretai čia taip pat atsakoma juokaujamai, žaidžiant panašiais žodžiu saskambiais, pvz.: -Ka sakai? Akys kaip guzikai ST 851 Vlkv; -Kq veikia? -Tave peikia ST 851 Ds; $-A$ jau viskas?- Katés piskas! Šk ir pan.

Paralelizmai būdinga patarliu sandaros ypatybè. Dvinarès patarlès dažniausiai remiasi tụ pačiu gramatinių formu veiksmažodžiu gretinimu, pvz.: Su gandrais išsikelsi su varnomis nukrisi (besipuikuojančiam) PP 416 Ms; Senam dera patarti, jaunam - paklausyti PP 230; Ka negirtas galvoja, tq girtas iškloja ST 138 Srd. Neretai pasitaiko ir tokiu paralelizmub kuriuose gretinami kontrastingi dalykai, vadinamuju antiteziu, 
pvz.: Jaunas tinginiausi senas ubagausi; Gerq peiksi neišpeiksi, bloga girsi - neisgirsi PP 181 Erž; Akyse giria, už akiu spiria PP $105 \mathrm{Krs}$; Kol gyvena, tol burblena PP 97 Rk; Bałsu saldus, darbais kartus KM 2654 Lzd.

Kartais ivairias kalbos etiketo situacijas nusakančioms patarlèms būdinga elipsè, t.y. kurios nors sakinio dalies praleidimas, pvz.: Vienas apie batus, kitas apie ratus (apie nesusikalbančius) Snt; Akyse - kaip šilkas, už akiu - kaip vilkas PP 105 Vs; Boba senyn - liežuvis ilgyn PP 89 Btg; Pirma meiliai, paskui-peiliai PP 128 Trg; Kas širdy, tas ant lieżuvio PP 96 Pn.

Minètos semantinès ir sintaksinès stiliaus figūros drauge kuria specialia sakinio ritmika, kuri taip pat parodo posakiu poetinès funkcijos svarba. Pažymètina, kad patarliu ritmika kartais remiasi ne vien tos pačios kalbos dalies gramatiniu formu atkartojimu, bet ir kitokiu sąskambiu kūrimu, pvz:: Kas tèvu neklauso, valgo duona sausq PP 151 Gdr; Pirma meiliai, paskui - peiliai PP $128 \mathrm{Trg}$; Atmink, mano vaike: daug kalbèt nereikia PP 166 Ds.

Ivairių kalbos etiketo situacijų kalbiné raiška rodo, kad poetinę funkcija paprastai atspindi ivairūs smulkiosios tautosakos žanrai, rečiau kitos frazès. Stiliaus figūros būdingos ivairiai kalbos etiketo tematikai (pasisveikinimas, prašymas, kvietimas užeiti, pasiteiravimas ir pan.). Iš semantinių priemonių dažniausiai vartojamos metonimija ir metaforos atmainos (hiperbole ir ironija), rečiau pasitaiko jasmeninimo, oksimorono. Darybinès figüros kalbos etiketo situacijose vartojamos retai. Jos kiek dažnesniau pasitaiko tik tada, kai kalbama apie miegą. Iš sintaksinių figũrų kalbos etiketo raiškai būdingi kreipiniai, retoriniai klausimai, paralelizmai, elipsés. Dažnai poetinę kalbos raišką kuria speciali frazès ritmika. 


\section{SUTRUMPINIMAI}
Al - Alytus
Alz - Alizava, Kupiškio raj.
An - Anykščiai
Btg - Betygala, Raseinių raj.
S.Dauk - S.Daukantas
Ds - Dusetos, Zarasu raj.
Erž - Eržvilkas, Jurbarko raj.
Gdr - Giedraičiai, Molètu raj.
Grš - Griškabūdis, Šakių raj.
Gs - Geistarai, Vilkaviškio raj.
Jnš- Joniškis
Jz - Jieznas, Prienų raj.
Kkt - Kuktiškès, Utenos raj.

KM Krèvè Mickevičius V. Patarlès ir priežodžiai.

Kaunas, 1934-1937 (skaičius rodo eilès numeri)

Kok Kokare E. Latviešu un lietuviešu sakāmvārdu paralēles.- Rīga, 1980 (skaičius rodo puslapi)

Kp - Kupiškis

Krkl - Karklènai, Kelmès raj.

Krn - Kruonis, Kaišiadoriy raj.

Krs - Karsakiškis, Panevéžio raj.

Krž - Kražiai, Kelmès raj.

Kt - Keturvalakiai, Vilkaviškio raj.

Lkš - Lukšiai, Šakių raj.

LKŽ - Lietuvių kalbos žodynas (I- XVIII t.)

Lzd - Lazdijai

MI - Molètai

Mrj - Marijampolè

Ms - Mosèdis, Skuodo raj.

$\mathrm{Nm}$ - Kudirkos Naumiestis, Šakių raj.

Pn - Panevéžys

PP Patarlès ir priežodžiai. V., 1958 (skaičius rodo puslapi) 
Ps - Pasvalys

Rk - Rokiškis

Rm - Ramygala, Panevėžio raj.

Sn - Seinai

Snt - Sintautai, Šakių raj.

Srd - Seredžius, Jurbarko raj.

Ssr - Siesartènai, Šakių raj.

ST Smulkioji tautosaka. V 1968 (skaičius rodo puslapi)

Svlk - Suvalkai

Šd - Šduva, Radviliškio raj.

Šk - S̆akiai

Škn - Šakyna, Šiaulių raj.

Šl - Šiauliai

Šll - Šilalè

Švnč - Švenčionèliai

Trg - Tauragè

Tvr - Tverečius, Ignalinos raj.

Up - Upyna, Šilalès raj.

VIkv - Vilkaviškis

Vs - Veisiejai, Lazdiju raj.

Všk - Vaškai, Pasvalio raj.

Žd - Židikai, Mažeikiu raj.

Žvr - Žvirgždaičiai, Šakiu raj. 


\section{LITERATŪRA}

Emstsone 1997 Ernstsone V Valodas spēle latviešu sarunvalodā funkcionalā skatîjumā. - Linguistica Lettica 1 . R., 1997, p. 76-99.

Girdenis 1995 Girdenis A. Teoriniai fonologijos pagrindai. - Vilnius, 1995.

Grigas 1968 - Grigas K. Smulkioji lietuvių tautosaka. Smulkioji tautosaka. - Vilnius, 1968.

Karaliūnas 1997 - Karaliūnas S. Kalba ir visuomenè: Psichologiniai ir komunikaciniai kalbos vartojimo bruožai. Vilnius, 1997.

Pikčilingis 1992 - Pikčilingis J. Iš patarliu, priežodžiu, misliu stilistikos. Lietuvių kalba mokykloje. T.4.- Kaunas, 1992, p. 75-88.

Savukynas 1977 - Savukynas B. Leidinio paskirtis ir kalba.- Žmonès ir kalba.- Vilnius, 1977, p. 15-22.

Żuperka 1997 - Župerka K. Stilistika. - Šiauliai, 1997.

Аврорин 1975 Аврорин В. Фунщии языка.

Проблемы изучения функциональной сторовы языка. Ленинград, 1975.

Леонтьев 1974 - Леонтьев А.А. Функщии и формы речи. - Основы теории речевой деятельности. - Москва, 1974. 


\section{DIE SITUATIONEN DES ETIKETTS DER SPRACHE UND DIE POETISCHE FUNKTION Zusammenfassung}

Wie die Ausdrucksweise in verschiedenen Situationen des sprachlichen Etiketts zeigt, wird die poetische Funktion durch unterschiedliche Gattungen des Volksschaffens, seltener durch andere Phrasen ausgedrückt. Sie ist typisch für verschiedene Themenbereiche des sprachlichen Etiketts: für Begrüßung (Sveiki gyvi. Sveiki, tik nelabai gyvi), Bitte (Parodyk... - Parodyms piniga kaštuoja), die Einladung hineinzutreten (Ar galima? - Prašom pro kaminq), Erkundigung (Kiek laiko? - Kiek pakelia, tiek ir laiko) u.ä.

Die poetische Funktion spiegelt sich durch den Gebrauch verschiedener Stilformen wider. Von den semantischen Sprachmitteln werden am häufigsten Metonymie, Ersetzungen der Metapher - die Hyperbel und Ironie verwendet, z.B. Liežuvis żmogu pakaria, liežuvis ir paleidžia; Boba senyn, liežuvis ilgyn; Žodžiu qžuolus varto, darbu ir skiedros nepakelia. Seltener kommen Personifikation und Oxymoron vor. Die Elemente der Wortbildung in den Situationen des sprachlichen Etiketts gebraucht man selten. Häufiger erscheinen sie in der Erzählung vom Schlaf (Eisim i Miknaičius pas Plunksniu).

Von den syntaktischen Figuren sind für die Ausdrucksweise des sprachlichen Etiketts die Anrede (Juozai garbüzai, duok miltu buzai), rethorische Fragen (Kas kels suniui uodega kad ne pats?), Parallelismen (Su gandrais išsikelsi - su varnomis nukrisi), Ellypsen (Kas širdy, tas ant liežuvio) charakteristisch. Die poetische Ausdrucksweise der Sprache wird manchmal die durch die spezifische Rhythmik der Phrase geschaffen. 


\section{VALODAS ETIKETES SITUĀCIJAS UN POẼTISKĀ FUNKCIJA \\ Kopsavilkums}

Dažādu valodas etiķetes situāciju valodiskā izpausme rāda, ka poētisko funkciju parasti atspoguło dažādi sīkās folkloras žanri, retāk - citas frāzes. Tā ir raksturīga dažādai valodas etiḳetes tematikai: sasveicināšanās ( Sveiki gyvi. - Sveiki, tik nelabai gyvi), lūgums ( Parodyk... Parodyms piniga kaštuoja), ielūgums ienākt ( - Ar galima? - Prašom pro kamina), jautājums (Kiek laiko? - Kiek pakelia, tiek ir laiko) u.tml.

Poētiskā funkcija atklājas, lietojot dažādas stila figūras. No semantiskajiem līdzekliem visbiežāk lietojamas metonīmija un metaforas paveidi hiperbola un ironija, piem.: Liežuvis žmogu pakaria, liežuvis ir paleidžia; Boba senyn, liežuvis ilgyn; Žodžiu qżuolus varto, darbu ir skiedros nepakelia (par lielībnieku) u.tml. Retāk sastopama personifikācija ( $K a$ tik tu tai Giltinèlei pažadejai, kad ant šio svieto dar paliko?), oksimorons ( $\mathrm{Nu}$, kirviai, kilkit iš vandens). Jaundarinātas figūras valodas etiķetes situācijās izmantojamas reti. Tās nedaudz biežāk sastopamas tad, kad tiek runāts par miegu (Eisim i Miknaičius pas Plunksniu).

No sintaktiskajām figūrām valodas etiķetei raksturīgas uzrunas formas (Juozai garbüzai, duok miltu buzai), retoriskie jautājumi (Kas kels šuniui uodega kad ne pats?), paralēlismi (Su gandrais išsikelsi - su varnomis nukrisi), elipses (Kas širdy, tas ant liežuvio). Bieži poētisko valodas izpausmi rada speciāla (specifiska) frāzes ritmika. 


\section{Ieva ZAUBERGA}

\section{FEMINISMA IETEKME UZ MŪSDIENU TULKOSANAS TEORIJU UN PRAKSI}

Tulkojumi tiek radīti konkrêtā telpā un laikā un tādējādi kalpo par sava laikmeta iezīmju spoguli. Tulkojumos varam atpazīt konkrētas kultūras situācijas, ieskaitot arī ideologijas. Ideologiskā dimensija tulkojumos atrodama vienmēr. Tā var büt klaji deklarēta un acīmredzama, bet pārsvarā gadījumu tā ir maskēta. Klaji ideolog̣izēti bija, piemēram, franču klasicisma laikmeta "uzlabotie tulkojumi", kad origininālteksti tika pārveidoti atbilstoši šì literārā virziena estētikas prasībām, vai arī 1968.gadā ang|u un franču valodā pārtulkotais Milana Kunderas romāns "Joks" franču tulkojumā tika līdz nepazišanai izskaistināts Kunderas stils, bet ang|u tekstā izlaistas filozofisko pārdomu epizodes par morāvu tautas mūziku, aizbildinoties ar to, ka anglu lasītājam tās šķistu garlaicīgas. Abos gadījumos tika nonivelētas oriğinālkultūras nianses un isstenota asimilācija, atklājot lielo kultūru neieinteresêtību mazo kultūru savdabībā. Taču ideologijas ietekme var arī nebūt tik tieši uztverama. Piemēram, pēdējo gadu latviešu tulkojumu atvērtỉba rietumu masu kultūras ietekmei (tiešie aizguvumi, necenzēto vārdu burtiska tulkošana, arī tulkojamo autoru izvēle) lielā mērā skaidrojama ar stingrajiem padomju laika aizliegumiem, kuru pēkšñā atcelšana likusi latviešu valodas lietotājiem mesties otrā galējībā.

Pēdējā laikā tulkojumu ideologiskie aspekti piesaistijjuši zinătnieku uzmanību daudzās pasaules valstīs. Savu ietekmi uz tulkošanas teoriju atstājusi arī feminisma ideolog̀ija. Dzimumu līdztiesības problēmas tulkojumu kontekstā tiek pētītas līdzās tādiem ar ideologiju saistītiem jautājumiem kā lingvistiskā hegemonija, kultūru asimilācija, identitāte, personības hibridizācija. Feminisma tulkošanas teorija, kas radusies Kvebekã šĩ gadsimta astoṇdesmitajos gados, mēgina pārveidot 
ierastos tulkošaras paṇērnienus, lai pievērstu uzmanību dzimumu lĩdztiesības jautājumiem ne tikai tulkojumu valodā, bet arī plašākā vēsturiskā, psihologiskā un ideologiskā kontekstā. Feminisma tulkošanas teorijā var izdalīt trīs galvenos virzienus:

- mēginājumi apkopot un izvērtēt līdz šim pilnīgi novārtā pamesto sieviešu tulkotāju un teorētiķu ieguldījumu;

- atmaskot patriarhālās ideologijijas, kas veido rietumu tulkošanas teorijas pamatus;

- izveidot mūsdienīgu attieksmi pret tulkošanas procesu un ieviest jaunus tulkošanas paṇēmienus; tiek diskutēti jautājumi, vai feministiskas ievirzes tulkotājām vispār vajadzētu tulkot no dzimuma aspekta šovinistiski noskanotu autoru vīriešu darbus, un, ja jā, tad kādā veidā; vai tulkotājām vajadzētu pievērst lasîtāju uzmanību seksisma izpausmēm oriǵināltekstu valodā; vai vajadzētu atmaskot oriǵināltekstos atrodamo tradicionālo vērtību sistēmu diskriminējošo raksturu un mēgināt pārveidot šo sistēmu atbilstoši progresīvākam domāšanas veidam; kā radīt jaunu, nediskriminējošu valodu. (Robinson, 1997: 236)

Feminisma kustības aizsākumi meklējami 18. gadsimta apgaismības laikmetā, kad sabiedrisku nozīmību ieguva kustība pret vīriešu un sieviešu sociālo nevienlīdzību. Sākotnēji feminisms bija izteikti politiska kustība jeb "vienlīdzīgu tiesību" feminisms, kura mērḳis bija nodrošināt sievietēm vēlēšanu tiesības, tiesības pēc laulībām paturēt savu īpašumu, tiesības šḳirties, tiesības iegūt augstāko izglītību. Šodien priekšplānā izvirzās "radikālais feminisms", kas uzskata, ka vīrieši noteikuši pašu priekšstatu, ko nozīmē būt sievietei, nospiežot sievieti sekundārā pozīcijā sabiedrībā. Viens feminisma atzars skar arī valodu, literatūru un tulkošanu.

Feminisma tulkošanas teorija nebūtu iespējama bez poststrukturālisma diskursa, kas izdarījis apvērsumu tradicionālajās attiecībās starp oriğinālu un tulkojumu. Tradicionāli tulkojumi tiek uzskatīti par nenoliedzami mazvērtīgāku darbu nekā oriğināls. Oriğināls ir mūžīgs, tulkojumi noveco. Oriğināls ir pašizpausmes veids, tulkojums 
tikai kopija. Pēdējās desmitgadēs izdarīti vềrā ṇemami mēginājumi no jauna izvērtêt tulkojumu lomu mūsdienu kultūrvidē. Vienkāršoti var teikt, ka oriğināls ir gāzts no troṇa. Tiek apšaubīts pretstats starp oriğinālu un tulkojumu, kā arī paša origināla viengabalainība. Ja tradicionāli par tulkojuma vērtíbu tika uzskatīta tā pilnīga pak|aušanās orig̉ināltekstam, savas sejas un rakstura izdzēšana, tad poststrukturālisti uzsver, ka tulkojums uzskatāms par originināla tālākattīstību. Ar tulkojuma palīdzîbu orig̀ināls tiek pilnveidots, pabeigts. Ja origināāltekstam nepieciešama pabeigšana, tas nozīmē, ka oriǵināis nav nevainojams, pilnīgs, absolūts. Poststrukturālisti ierasto orig̣ināla tulkojuma attiecibu modeli O(RIĢINĀLS)

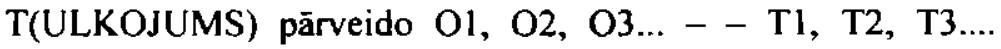
uzsverot, ka neviens teksts nav galīgs un ka teksta nozīme ir atkarīga no interpretācijas un tātad no tulkotāja. Piemēram varētu izmantot Šekspīra "Hamletu" Tradicionālo shēmu varam interpretēt: viens oriğināls jeb šajā gadījumā "Hamlets", viens veids, kā to lasīt. Bet poststrukturālisti apgalvo, ka neviens teksts nav "stabils", t.i., katru reizi, to lasot, no jauna atklājas jaunas tā nianses un nozīmes. Labā origìināltekstā slēpjas neskaitāmas interpretācijas iespējas. Tulkojums atklāj jaunas origininālteksta nianses, tādējādi bagātinot oriǵināltekstu. Ja izlasām "Hamleta" tulkojumu un tad atgriežamies pie orig̣ināla, atradīsim tajā kaut ko iepriekš neatklātu. Ja tradicionālā oriğināla tulkojuma shēma $O \quad T$ parāda sakarïbu "viens vai otrs", tad poststrukturālais modelis $\mathrm{O} 1, \mathrm{O} 2, \mathrm{O} 3, \mathrm{~T} 1, \mathrm{~T} 2, \mathrm{~T} 3 \ldots$ interpretējams kā "abi vai neviens" Tātad notiek oriğināla un tulkojuma mijiedarbỉba, un saikne starp abiem ir lasītājs jeb šajā gadījumã tulkotājs.

Poststrukturālisti uzdod daudz provokatorisku jautājumu: ja nu mēs apgalvotu, ka bez tulkojuma origināls beidz pastāvēt? Ka oriǵināla izdzīvošanas iespējas kādā kultūrvidē ir ne tik daudz atkarīgas no paša originālteksta kvalitatīvajiem rādītājiem, bet gan no attiecīgā tulkojuma kvalitātes? (Gentzler, 1993: 145) Tik tiešām, vai gan trūkst piemēru, kad slikta tulkojuma dēl netiek novẽrtēti izcili autori? Kaut vai Ĵvlins Vo 
un Džons Apdaiks latviešu kultūrvidē. Poststrukturālisma diskurss pakāpeniski novedis pie Autora / Oriğināla absolūto pozīiju erozijas un "autora nāves" (death of the author). Şis nu jau labi zināmais postulāts savukārt radījis koncepciju "lasītāja dzimšana" (birth of the reader), ko tulkošanas teorija interpretē kā tulkotāja lomas nostiprināšanos, aktīvi radoši iesaistoties un reizēm arī iejaucoties oriḡinālteksta "pārrakstǐšanas" procesā atbilstoši jaunās kultūras situācijas izvirzītajiem noteikumiem. Jo tulkošana vairs netiek uzskatīta par statisku oriğinālteksta atveidošanu tulkojumvalodā, bet gan mērkstiecīgu darbību, kuras rezultātā tiek radīts jauns teksts, kurš spējīgs funkcionēt jaunajā kultūrvidē atbilstoši tā lietotāju vajadzībām (Nord, 1997:29). Vairāki tulkošanas teorētiḳi, piemēram, Lorenss Venuti, uzstāj, ka pienācis laiks tulkotājam iznākt no aizkulisēm un skạıi teikt savu vārdu (Venuti, 1995). Šo ideju tālāk attīsta arī feminisma tulkošanas teorija.

Feminisma tulkošanas teorija velk paralēles starp "otršķirīgumu", kas tradicionãli piedēvēts gan sievietēm, gan tulkojumiem. Vẽsturiski attiecīgajās hierarhijās tulkojumi un sievietes uzskatītas par vājākajiem elementiem: tulkotāji kā iztapīgi kalpi autoram, sievietes kā vīriešu palīgfunkcijas. "Esmu uzskatāma par tulkojumu, jo esmu sieviete," saka Sjūzena Delotbinjēra Harvuda (1991, citēts no Simin:1). Feminisma tulkošanas teorijas mērḳis ir revidēt un kritizēt tos jēdzienus un nostādnes, kas gan sievietei, gan tulkojumiem ierāda zemāko vietu sociālajā un literārajā hierarhijā.

Par pirmo uzdevumu feminisma tulkošanas teorija izvirza mest izaicinājumu seksismam valodā. Feministes norāda, ka pastāv daudz valodu, kuras piedalās sieviešu apspiešanā. Pārāk bieži mēs runājam vīriešu valodā, saka Harvuda (1995, citēts no Simin:31). Piemēri nav tālu jāmeklē arī latviešu valodā: Mēs visi - viens zèns un simts meitenes - jau esam apguvuši šo valodu. Klasē ir 32 skolēni / skolnieki (25 meitenes un 7 zēni). Bet pamēǵināsim zēnu nosaukt par skolnieci! Feministiskas ievirzes tulkotājas uzskata, ka šajos procesos jāiejaucas, tulkojumos skaidri atmaskojot tradicionāli ierastās un tādē| ne 
vienmēer pamanîtās sociālās netaisnỉbas. Šim nolūkam izstrādāta stratēgija, ko dēvē par "teksta apstrādi sievietes interesēs" (womanhandling the text). Piemēram izmantošu Luīzes van Flotovas piedāvăto piemēru: franču tekstā, kur runāts par aborta politiku valstī, atrodams teikums $L e$ ou la coupable doit etre punie [Tas, kurš ir vainīgs, ir sodāms]. $E$ burts pagātnes divdabī punie skaidri norāda, ka aborta gadījumā sodāma ir sieviete. Ang|u tulkotāja, uzṇemoties politiskā vidutāja lomu, šo teikumu atveido The quilty one must be punished, whether she is a man or a woman. [Vainīgais jāsoda, vai tā būtu sieviete vai vīrietis.] Luize van Flotova nosauc šo konkrēto tulkošanas metodi par papildināšanu (supplementing). Pēc vinnas domām, biklo tulkotāju laiks, kad tika radīti gludi, neuzkrītoši tulkojumi, ir pagājis. Feministiskās ievirzes tulkotājas rada tekstus, kur atstāj savu parakstu, izmantojot kursīvu, zemteksta piezīmes, priekšvārdu un tā aktīvi piedaloties teksta nozīmes radīšanā (1991:76). Sjūzena Delotbinjēra Harvuda atklāti atzīst: "Mana tulkotājas darbïba ir politisks akts, kura mērḳis ir likt valodai aizstāvēt sieviešu intereses" (1995, citēts no Simin:15).

Feministiski ievirzìtās tulkotājas ir konsekventas un radikālas, ar savu darbību cenšoties atmaskot "fallocentrismu, kas atrodas Rietumu visu institūciju, ieskaitot baznīcu, darbības pamatā" (Simin, 1996:17). Ar šādu motivāciju tās pārstrādā arī Bībeli $k \bar{a}$ institucionalizētās relig̣ijas pamatu. Viena no kaismīgākajām Bībeles kritizētājām bija Elizabete Kedija Stentona (1815-1902). Viña raksta: "Bībele māca, ka sieviete ienesusi pasaulē grēku un nāvi, ka viṇa veicinājusi cilvēku dzimuma pagrimumu, ka vinaai nācās stāties Debesu tiesas priekšă, kas vinu tiesāja, nosodijja un piesprieda sodu. Laulību viñai nācās pieṇemt kā verdzību, kur viņa bija nolemta atkarībai, bērnu radīšanai, ciešanām un sāpēm; klusi un padevīgi vinai klājās pa|auties uz savu vīru kā visu materiālo vajadzību apmierinātāju, kā arī izziņas avotu, lai rastu atbildes uz sev svarīgiem jautājumiem. Šādi īsumā var raksturot Bībeles skatîjumu uz sievietes vietu sabiedribā." (1972:7) 
Feministes mēgina piesaistīt sabiedrības uzmanỉbu seksimam bībeles tulkojumos. Vairākas no viṇām iemācījušās senebreju valodu, lai noskaidrotu, vai origininālteksts ir tikpat diskriminējošs kā tā ang|u tulkojumi. Viṇas atklāja, ka daudzas Bỉbelē izteiktās atziñas ir atkarīgas no interpretācijas. Piemēram, tradicionāli senebreju vārds adam tiek tulkots kā vīrietis, no kura ribas vēlāk tika radīta sieviete. Filisa Tribla savā tagad plašu atzinību guvušajā Pasaules radīšanas interpretācijā parādījusi, ka orig̣inālu tīri semantiski var saprast arī tā, ka būtne, ko Dievs radīja no māla, sākotnēji nebija ne vĩrietis, ne sieviete. Cilvēces dalījums dzimumos noticis vēlāk. Feministes arī uzskata, ka Dieva apzīmējums "Tēvs" būtu aizstājams ar "(Dievs) Tēvs (un Māte)", jo "Dievs Tēvs" nebūt nenozīmē, ka Dievs ir tēvs, bet gan ka Dievs ir kā tēvs. Tādē| mūsdienu interpretācijā Dievs var tiklab būt gan kā tēvs, gan kā māte.

Tomēr pastāv ar̄i atšḳirīgs viedoklis. Daudzas feministes uzskata, ka Bībeles tulkojumi nebūtu maināmi, jo tie atspogulo lietu patieso stāvokli. Nav nekādas vajadzības likt sievietei “justies kā mājās" pasaulē, kas pēc savas būtības ir diskriminējoša.

Nobeigumā gribētu saistīt š̄is nostādnes ar Latvijas pašreizējo kultūrvidi. Neskatoties uz plaši izvērsto feminisma kustību daudzās pasaules valstīs, īpaši Amerikā un Ziemelvalstīs, Latvijā feministu centieni tiek uzṇemti diezgan rezervēti. Bieži nākas sastapties ar ironisku attieksmi gan no vīriešu, gan sieviešu puses. Ārzemnieki šo attieksmi skaidro ar to, ka pagājis pārāk îss laiks, lai Latvijā būtu varējis nostiprināties demokrātisks domāšanas veids un ka vienkārši ir nepieciešams laiks, līdz Latvijas sabiedrība nonāks līdz Rietumu demokrātijas attīstības pakāpei. Līdzīgi kā vajadzīgs laiks, lai sabiedrỉba atbrīvotos no nacionālistiskajiem aizspriedumiem. Taču jārēḳinās arī ar faktiem - Latvijā sievietes nekad nav bijušas diskriminētas klaji politiskā veidā. Piemēram, vēlēšanu tiesības pirmā Latvijas Konstitūcija piešḳīa vienlaicīgi gan vīriešiem, gan sievietēm 1922. gadā. Arī padomju laika "vienlīdzìba", kad sievietes varēja redzēt pie traktora stūres vai rokam grāvjus, 
atstājusi savu ietekmi. Kā norāda Andra Neiburga, lielākajai da|ai sieviešu, kas dzīvojušas "sociālistiskās vienlīdzības" apstāklos, tik labi pazīstamais Kinder, Küche, Kirche liekas dižākais "kapitālisma iekarojums" ("Literatūra un māksla", 07.08.92. 4). Gundega Repše, aprakstot 1992. gada Amsterdamas feministu kongresu, sniedz sabiedribai diezgan tipisku sievietes pašsajūtas atspogu|ojumu: "Kad ieslīdu sieviešu feministu simtgalvainajā pulkā, jūtos pāāāk veselīga un laimīga. Kad iespraucos lezbiešu apmeklētā koncertā, kur vinas skūpstās un knibinās; nešaubīgi alkstu joṇot uz "sarkano rajonu" Piedevãm zivēru sev atkal ataudzët bizes. Redzot tik daudz sieviešu uzvalciṇos, robustās žaketītēs, ezīšos, kosmētikas neskartām sejām, rodas pārliecība atlikušo mūžu nostaigāt mežgin̄īì̄ēs, špicītēs, rišiņās, apakšsvārciṇos, krūšturīšsos un smaržot pēc pašas ceptām piparkūciṇām" (ibid). Vīriešu attieksmi raksturo Latvijas Parlamenta spîkera Alfrēda Čepāṇa izteikumi. Kādā intervijā, jautāts, ko visaugstāk vērtē sievietē, Čepāna kungs atbild - skaistumu. Intervētāja neliekas mierā un atgādina par gudrību. Atbilde ir skaidra: "Tas atkarīgs no kopā pavadītā laika. Un tomēr, viṇai nevajag būt pārāk gudrai. Līdz šim man laimējies ar kolēgèem un citām sievietēm" (Pasaules atbalss: 07.97:: 3).

Ar šiem citātiem negribu apgalvot, ka Latvijas sabiedrībā nepastāvētu arī citādi uzskati. Atcerēsimies kaut vai lielo feministiski ievirzīto konferenci "Sievietes un vīrieši dialogā", kas notika 1997. gada vasarā Valmierā, Latvijas Universitātē nesen nodibināts "Dzimtes studiju centrs", arī publikācijas presē un, piemēram, Ausmas Cimdiñas sastādīto grāmatu "Feminisms un literatūra" (1997). Tomēr tulkotājam jārēḳinās ar tā saucamo "vidējo lasītāju", kura viedokli iepriekš minētie izteikumi, manuprāt, raksturo diezgan trāpīgi.

Ja gribam radīt funkcionāli adekvātu tulkojumu, izvēloties tulkojuma stratēg̣iju, rūpīgi jāizvērtē sabiedrības noskaṇojums. Rietumu feministu ieviestā "teksta apstrāde sievietes interesēes" Latvijā šobrīd atradīs maz atbalstītāju. Šis metodes pielietojums nedrīkstētu būt vispārējs, to varētu 
mërķtiecīgi izmantot vai nu tulkojot attiecīga rakstura politiskus tekstus, vai arī ar nodomu ideologizēt politiski neitrālu tekstu. Jo klaja ideolog̣iska iejaukšanās no tulkotāja puses nenovēršami mainītu tulkojuma funkciju, kā mēs to varējām vērot dažos padomju laika tulkojumos. Piemēram, Žana Pola Sartra luga "Respektablās maukas" krievu valodā piedienīgi pārdēvēta par "Liziju Makeju", pie tam ideologiski uzlabotā varone lugas nobeigumā pievienojas miera kustībai (Avots, 09.-10.91.:34). Līdzīgi arī, apstrādājot oriǵināltekstu no feminisma pozīcijām, tulkojums sāk pildīt no oriğināla atšksirīgu funkciju. Ja tas ir paša tulkotāja vai tulkojuma pasūtītāja nolūks, tad mūsdienu funkcionālisma teorija šādu "intervenci" pie|auj ar nosacījumu, ka "spēlējam ar atklātām kārtīm" un lasītājs tiek informēts par notiekošo tulkojuma priekšvārdā, pēcvārdā vai vēl kādā citā veidā. Kristiāna Norda šādu pieeju sauc par lojalitāti (1997: 125)

tulkotāja atbildību gan oriğinālteksta autora, gan lasîtāja priekšā. Ja tulkojums neveic nekādu ārkārtēju ideoloǵisku misiju, ekvivalenta efekta sasniegšanai tulkotājam jāpielāgo teksts jaunās kultūras situācijas īpatnībām. Ja recipients ir jūtīgs pret iespējamām seksisma izpausmēm valodā kā latviešu tekstu angliskā tulkojuma lasītāji dažādās valstīs, tulkotājam jācenšas novērst šis nevēlamais efekts. Konsekventa vīriešu dzimtes personu vietniekvārda lietošana attiecībā uz abu dzimumu pārstāvjiem latviskajā kultūrvidē pagaidām vēl nerada seksisma iespaidu, kamēr šī lietojuma saglabāšana anglu tulkojumā varētu izraisīt nevēlamu reakciju. İpaši, ja tulkojamais teksts ir tik politiski jutīgs teksts kā, piemēram, Pilsonības likums. Tādē] tulkotājs ang|u tekstā lietojis abu dzimšu personu vietniekvārdus. Piemēram, Pilsonības likuma 3. panta fragments:

Ja bērna dzimšanas brīdi viens no vecākiem ir Latvijas pilsonis, bet otrs - ärvalstnieks, bērns ir Latvijas pilsonis, ja vinš:

If, on the day of the child's birth, one of the parents was a citizen of Latvia and the other parent was an alien, then the child shall be a citizen of Latvia provided that he/she:

Varam arī iedomāties situāciju, kad kāda starptautiska organizācija izvēlējusies Pilsonības likumu, lai meklētu Latvijā 
dażāda veida diskrimināciju pazīmes. Tādā gadījumā tulkojumam būtu cits mērķis, un vīriešu dzimtes personu vietniekvārda lietojums tiktu saglabāts. Līdzīgi šis mehānisms darbojas arī tulkojumos no anglu valodas latviešu valodā. Piemēram, brošūras "Parlamentārās vēlēšanas Lielbritānijā" ang|u teksta pirmajâ lapã atrodama zemteksta piezīme:

For the sake of convenience, the masculine pronoun is used throughout this pamphlet, but the information given applies equally to men and women unless the context clearly indicates otherwise. [Értības labad šajã brošūrā lietots vīriešu dzimtes vietniekvārds, bet sniegtā informācija vienādā mērā attiecas kā uz vīriešiem, tā sievietēm, ja vien konteksts skaidri nenorāda uz pretējo.]

Tiecoties panākt funkcionālo ekvivalenci, šī zemteksta piezīme izlaista latviešu tulkojumā. Latviešu kultūrvidē šāda veida piezīmes nav raksturīgas un, iespējams, izraisītu izbrīnu vai ironisku piezīmi. Turpretī, ja tulkotāijs gribētu salikt tulkojumā pavisam citus akcentus un vienlaicīgi izraisīt diskusiju gan par vēlēšanu sistēmas, gan dzimumu līdztiesỉbas nodrošinājuma atšķirībām Lielbritānijā un Latvijā, tad šo piezīmi noteikti vajadzētu tulkojumā saglabāt.

Gribētu izmantot abus šos piemērus, lai vēlreiz uzsvērtu atškiribu starp profesionālu un politizētu tulkojumu. Feministiskas ievirzes tulkotājas šobrīd faktiski aicina ideologizēt tulkošanas procesu. Tulkošana tiek izmantota kā viena no darbỉbas sfērām savu politisko mērḳu sasniegšanai. Kamēr apzināmies mērḳi, kādu izvirzām katram konkrētam tulkojumam, varam raudzīties uz feminisma tulkošanas teoriju un praksi kā jaunu, radošu un drosmīgu ideologiiskās cīṇas paveidu. Tulkojuma mērķis attaisno izvēlēto tulkošanas stratēgiju. Bet feminisma tulkošanas metožu nediferenciēta izmantošana var viegli novest pie originālteksta izkroplošanas un liecinātu par tulkotāja profesionalitātes trūkumu. 


\section{IZMANTOTĀ TEORĒTISKĀ LITERATŪRA}

1. Gentzler E. Contemporary translation Theories. - Routledge, 1993.

2. Nord C. Translation as Purposeful Activity. - St. Jerome Publishing, 1997.

3. Robinson D. Becoming a Translator. Routledge, 1997.

4. Simin S. Gender in Translation. Routledge, 1996.

5. Stanton E. The Woman's Bible._New York, 1972.

6. von Flotov L. Feminist Translation: Contexts, Practices and Theories. In: TTR (Traduction, Terminologie, Redaction), 4, 2. 1991, p. 69-85.

7. Venuti L. The Translator's Invisibility: A History of Translation. Routledge, 1995.

\section{IMPACT OF FEMINISM ON CONTEMPORARY TRANSLATION THEORY AND PRACTICE Summary}

Translations are created in time and space and we can easily recognize concrete culture situations and ideologies from which they have emerged. Of late the ideological cause and consequence of translation has drawn the attention of scholars in many countries. Alongside with such ideology-related issues as linguistic hegemony, cultural assimilation, identity issues, gender equality problems in translational discourse have found their niche in contemporary translation studies. Feminist translation theory, which has emerged in Quebec in 1980ies, makes an attempt to alter conventional translation practice with a view of highlighting cross-gender issues in the process of crosscultural translational communication.

Feminist translators draw parallels between the "secondariness" of both women and translations. Translations and women have historically been the weaker figures in their respective hierarchies. Feminist translation theory aims to 
identify and criticize the tangle of concepts which relegate both women and translation to the bottom of the social and literary ladder. The most obvious measure seems to be challenging the sexism in language. Feminists try to resex the language by introducing a new translation strategy recognized as "womanhandling the text" They seek to flaunt their signature in italics, in footnotes, and in prefaces, actively participating in the creation of meaning. They take corrective measures also in relation to the Bible trying to put it in feminist frame.

In Latvia today feminist theories are received with certain reservations. The society in general shares a rather conventional attitude towards gender related issues which has to be reckoned with to create functional translations. A strict line has to be drawn between political translation and professional translation. Blatant ideological interventions may change translation skopos as we have witnessed in a number of Soviet time translations. In fact, feminist translators try to politicize translation process. As long as translation skopos is well defined, feminist translation theory and practice has to be recognized as a new and challenging mode of ideological struggle. Translation skopos justifies translation strategy. However, undifferentiated application of feminist translation methods can easily distort the source text intention and evidences of low professional standards. 


\section{GRAMMATU APSKATS}

\section{VAJADZĪGA UN NODERĪGA GRĀMATA T.Mathiassen. A Short Grammar of Latvian. Slavica Publishers; 1997. $236 \mathrm{p}$.}

Vērtējot norvēğu valodnieka Terjes Matiasena grāmatu "A Short Grammar of Latvian" pats pirmais atzinibas apliecinājums profesoram pienākas par to, ka viṇs ir paveicis vienu no latviešu valodnieku nepadarītajiem darbiem, kas bija kluvis īpaši aktuāls pēdējos desmit gados. Profesors ir uzrakstījis mācību gramatiku studentiem, cittautiešiem, anglu valodā.

Profesors T.Matiasens kā cilvēks, kas uzticīgs klasiskām vērtībām, latviešu valodas aprakstu ir sācis ar fonoloǵiju, kas konceptuāli gan îsti neiederas gramatika, taču, ņemot vērā grāmatas adresātu, ir ne tikai attaisnojami, bet pat nepieciešami. Nepilnās 18 lappusēs autoram ir izdevies izveidot kompaktu un pietiekami detalizētu latviešu valodas skaṇu aprakstu (fonētiku) un parādīt skaṇu modelus un to realizāciju (fonologijju), visu būtiskāko latviešu valodas skaniskās puses īpašỉbu kopumu.

Turpmākās nodalas ir veltītas lietvārda, adjektīva, vietniekvārda, skait\}a vārda morfolog̣isko kvalitāšu aprakstam.

Būtiskākā novitāte (sekojot T.Fennela 70. gadu vidū izteiktajai atziṇai) ir uzskats, ka mūsdienu latviešu valodā ir seši locījuni. Tradicionālajā gramatikā izdalītais instrumentālis nav atzīts par atsevišḳ locījumu. Netradicionāla ir arī vietniekvārdu sistēmas un semantiskās klasifikācijas interpretācija, t.i. savstarpējo vietniekvārdu (reciprocal pronouns) grupas izdalījums, arī anaforisko un t.s. citu vietniekvārdu nošķīrums (jāpiezīmē gan, ka būtu bijis labi šo vietniekvārdu grupu definēt noteiktāk). Abi jaunievedumi latviešu valodas gramatikā ir pozitīvi vērtējami.

Kā nekonsekvenci var vērtēt to, ka adjektīva apskatā ir apakšnodala par adjektīva sintaksi, taču lietvārda apskatā šādas apakšnoda|as nav, turpretī vietniekvārda un skait|a vārda 
aprakstā (kurā nav atsevišksas nodalas par sintaksi) faktiski pateikts diezgan daudz par šo vārdu "sintaktisko uzvedību"

Noda|āàs par nomeniem sastopamas arī vairākas neprecizitātes, piemēram, 45. lappusē teikts, ka 2.deklinācijas iregulāros lietvărdus akmens, asmens, mēness u.c. deklinē tāpat kā lietvārdu suns, taču ilustratīvajā materiālā datīva forma rādīta akmeñam (pareizās akmenim) vietā. Ir arī apgalvots, ka 2.deklinācijas deminutīviem ar -ītis (brälītis) vokatīvā likuma prasība ir veidot formu brälīi (45. Ipp.). Tas gan nav tiesa, š̄ tipa deminutīviem parasti veido bezgalotnes formu (brälīt! puisitt!); formas ar galotni $-i$ ir reti sastopamas, parasti dzejas valodā (kur tās ir ritma nosacìtas): Kārlīit, Kārlñi, Manu mazu brähtiti. (Rainis).

Apcerot formām bagāto darbïbas vārdu, profesors saglabājis mūsdienu latviešu valodniecībā parasto dalījumu trijās konjugācijās, kvalificējot tās kā ìso, garo (paplašināto) un jaukto un parădot katrai raksturīgākās izskaņas ar piemēriem. Pamatos darbïbas vārds ir labi aprakstīts, tomēr ne vienmēer tas izdevies nevainojami. Piemēram, pie 2.konjugācijas verbiem ar izskanuu -ît dots piemērs cienīt, taču šis vārds ir konjugējams divējādi: cienu, cieni, ciena... kā arī cienīju, cienī, cienī... pagātnē cienīju utt. Turklāt šḳiet, ka biežāk lieto tieši trešăs resp. jauktās konjugācijas formas. Visumā veiksmīgajā izteiksmju aprakstā ir ieviesušās arī dažas klūmes. Tã, skaidrojot konstrukciju veidojumu pēc verbum dicendi (128. Ipp.), ir teikts, ka anglu valodas konstrukcijām ar that atbilst divas konstrukcijas latviešu valodā: ka + ìstenības izteiksme/atstāstījuma izteiksme (Viňs sacija, ka ir/esot skaidrs laiks) un lai + vēlējuma izteiksme/atstāstījuma izteiksme (Viňs sacīja, lai es tūlìt nāktu/nākot). Šajā sakarā gan jāpiebilst, ka konstrukcijā ar lai parastāks ir istenības vai atstāstijjuma izteiksmes lietojums, un tikai trešajā vietā būtu ierindojama vēlējuma izteiksmes forma, kas, tiesa gan, teorētiski ir iespējama un pareiza.

Pozitĩvi vērtējams gerundiju (t.i., nelokāmo un dalēji lokāmo divdabju) un participu (divdabju) škīrums, pamatojoties uz to dažādajāın funkcijām. No funkcionālā viedok|a gerundiji 
kopā ar no tiem atkarīgajiem vārdiem veido adverbiālo (visbiežāk laika nozīmes) palīgteikumu ekvivalentu, bet participi pilda atributīvo un tai tuvo apozitīvo funkciju.

Diemžēl jānorāda uz vairākiem trūkumiem locījuma kategorijas apskatā. Piemēram var minêt apgalvojumu, ka latviešu valodā varot kombinēt subjekta un objekta genitīvu (Kolumba Amerikas atkläs̆ana), tiesa, ar piebildi, ka daudzi latvieši šādas konstrukcijas atzītu par diezgan neveiklām (167. lpp.). Formāli no gramatiskā viedok|a tas ir iespējams, taču latviešu valodā šāđs lietojums netiek akceptēts. Nav patiess arī konstatējums, ka vārdsavienojumam zelta gredzens alternatīva konstrukcija ir zeltains gredzens (168. Ipp.), jo neapzīmē vis materiālu, bet tikai norāda uz krāsu. Nav pienemams arī vārdsavienojums bagāts zivju ezers (168. Ipp.), pareizais būtu zivìm (reti zivju) bagāts ezers / ezers bagāts (ar) zivīm. Aprakstot vārdsavienojumus (no)pirkt piena / puķu un (no)pirkt pienu / pukkes (172. Ipp.), teikts, ka ar genitīvu izsaka objekta da]u, bet konstrukcija ar akuzatīvu apzīmëjot visu objektu, lai gan mūsdienu valodā šķietot iespējams lietot abas konstrukcijas bez īpašas atšk̆irīibas nozìmē. Jāpiezīmē, ka ne tikai iespējams lietot, bet mūsdienu valodā parasti tiek lietota konstrukcija ar akuzatīvu. Tâda tipa konstrukcijas kā nopirkties jaumu velosipèdu (174. lpp.) ar nozīmi 'nopirkt sev (ko)' lieto loti reti, un parasti tās lieto ar nozīmi 'tikt nopirktam (parasti par ko nevēlamu, arī mazāk noderīgu)', piemēram, gribēju ballu kreklu, bet nopirkās täds pelèks. Vēl varētu norādìt, ka konstrukcija lauva pieder pie zvēriem (178. Ipp.) veidota tiešām pēc pareiza mode|a, taču verbu piederét lieto tad, ja runa ir par piederību dzimtai: lauva pieder pie kaku dzimtas. Nominatīva sakarā grāmatā ir teikts, ka konstrukcijā ar fāzes verbu debitīvā, kam seko pilnnozīmes verbs infinitīvā, nomenu varot lietot vai nu nominatīvā vai akuzatīvā (181. Ipp.). Šajā gadījumā gan nav izvēles, vajadzīgo locījumu, proti, akuzatīvu, "prasa" pilnnozīmes vārds, kas nosaka šì saistījuma būtību: man jāsāk rakstīt vēstuli / *vēstule. 
Grāmatā ir arī dažas ne visai labi saprotamas vietas, piemēram, rindkopa lokatīva sakarā (180. Ipp.) ar galvenajiem vārdiem piedalīšanās, piedalīties, klausīties, kam sekojot kā (?!). Neizprotami arī, kāpēc noda|̧ā par saik|iem (194.-195. lpp.) nemaz nav iek|auti (vai pazuduši?) saikli ar vietas (!) nozīmi.

Arī teikuma sakarā būtu jānorāda uz dažām nepilnībām.

Ja apgalvo, ka sintaktiskais saistijums starp teikuma priekšmetu (nevis priekšmetu, kā teikts 196., 197. u.c. lpp.) un izteicēju veidots uz interdependences pamatiem, tādā gadījumā nepieciešams tomēr parādīt, kă tieši izpaužas šis savstarpējais atkarīgums. Tieši tas ir svarīgi šì saistījuma būtības izpratnei latviešu valodas gramatikā.

Skaidrojums (198. Ipp. sakarā ar predikāta uzbūvi), ka saitinas büt izlaidums pirms pagātnes divdabja (Rūdolfs Blaumanis dzimis Vidzemē) esot interpretējams kā atstāstījuma izteiksmes forma, kamēr forma ar eksplicītu būt (ir dzimis), protams, uzskatāma par īstenības izteiksmi, ir vienkārši aplams, jo saitiṇu, kā zināms, var elidēt tikai îsteníbas izteiksmes tagadnes 3. personā.

Teikumu iedalījumă pēc modalitātes deklaratīvajos (jeb apgalvojuma), imperatīvajos un jautājuma teikumos (202. lpp.) T.Matiasens sekojis tradīcijai, taču neraugoties uz to, ka ši tradīcija ir "ar garu jo garu bārdu", izrādīt cieņu tai tomēr nevar, jo no klasifikācijas likumu viedokla šie teikuma tipi nav nostatāmi līdzās. Klasifikācijas pamatviedoklis izriet no galvenajām komunikatīvajām darbībām (informācijas nodošana vai informācijas pieprasīšana), pēc kurām šķirami (1) nejautājuma teikumi un (2) jautājuma teikumi. Nejautājuma teikumus atkarībā no gribas izpausmes tiešuma pakāpes var iedalīt (la) stāstījuma teikumos un (1b) rosinājuma (pavēles, vēlējuma) teikumos. Izsaukuma teikumu izvirzījumam pamatā ir pavisam cits kritērijs - teikumā izpaustā emocionalitātes pakāpe. Pēc šĩ kritērija jebkurš no jautājuma vai nejautājuma teikumiem var būt izsaukuma vai neizsaukuma teikums (piemēram, $U n$ tu vēl esi šeit?!). 
Nevaru pienemt profesora atzinu, ka vienkomponenta teikumi, kas sastāv tikai no galvenā locekla, varētu būt raksta, meklē, sāka rakstīt (206. Ipp.). Vienkomponenta teikumi ar šāda tipa trīspersonu verbiem centră ir iespejjami tikai ar aktantiem vai situantiem: par to rakstija avizzēs, kugi šüpo, t.i., grāmatas 206. lappuses 2) un 3) rindkopā minētajos gadījumos.

Diskutējama man šḳiet profesora piedāvātā konstrukcijas nav sniega interpretācija, saskaṇā ar kuru vārds ǵenitīvā kvalificējams par objektu (206.-207. Ipp.). Pamatkonstrukcijas (Ir) sniegs modālā realizācija (ar nolieguma nozīmi) nemaina teikuma modẹ̣a būtību, pretējā gadījumā zūd (vai samazinās līdz minimumam) jēdziena "teikuma modelis" gnozeologiskā jēga. Dīvaini būtu, ja abas gramatiski un semantiski saistītās un līdzīgās konstrukcijas, kas atšķiras ar apgalvojuma / nolieguma modalităti, interpretētu tik atšķirīgi, ka apgalvojuma teikumā sniegs (nominatîvā) būtu subjekts, bet "nostādamies" ġenitīvā (kas ir rezultāts modalitātes maiṇai uz noliegumu) tas būtu mainījis orientāciju no "kreisās" uz "labo" un k|uvis par objektu.

Būtu jāatzīmē arī konceptuāla nekonsekvence sakarā ar infinitīvteikumiem. Saskañā ar profesora koncepciju būt tiek lietots eksistenciālā nozīmē konstrukcijā man nav ar ko runāt (207. Ipp.), tātad kā pilnnozīmes verbs, bet tãdā gadījumā šis ir salikts teikums ar atkarīgo komponentu ar ko runāt (sal. ar pamatkonstrukciju Ir, ar ko runāt).

Arī 208. Ipp. minēto konstrukciju bija zibens, būs putenis un zibens, putenis interpretācija neškiet piennemama, aplūkojot šis sintaktiskās parādības sistēmiskā aspektā. Vērtējot tās šādi, klūst skaidrs, ka tikai istenỉbas izteiksmes tagadnes 3. personā (kvalificējot faktu kā "reāls - tagad") iespējams elidēt büt, turklāt tikai apgalvojuma formā. Starp citu, elidēt modalitātes un laika rādītāju $b \bar{u} t$ nav iespējams uzsvērtā pozīcijā, un tā rāda, ka š̄ pozīcija patiešām eksistē, ir reāla: Puteņi ir 'bijuši un 'būs. Tādējādi ir iespējams izvairīties no gramatiski un semantiski saistīto un līdzīgo konstrukciju - (Ir) putenis Bija putenis Būs putenis - neloğiski atškirīiga interpretējuma. 
Grāmatas publicēšana acīmredzot notikusi lielā steigā, tas varētu būt izskaidrojums daudzajām korektūrā neizlabotajārn k|ūdām: menesis 25. Ipp. (mēnesis vietā), dzìvotājs 36. Ipp. (iedzivotājs vietā), bilete bilešu 47. lpp. (bilete bilešu vietā), pretkalpojums 55. lpp. (pretpakalpojums vietā), darzinś 73. Ipp. (därziņš vietā), Norveǵiju 133. Ipp., (Norvēgiju vietā), vienkaršo formu darīšana 85. Ipp. (vienkāršo formu darināšana vietā), plēst (96. lpp.): 1. p. plešu (plēšu vietā), 2. p. ples-Ø (plēs vietā), 3. p. pleś-Ø (plēśs vietā), skūt (100. lpp.) 1. p. skūju (skuju vietā), 2. p. $s k \bar{u}-j-\emptyset$ ( $s k u j$ vietā), 3. p. $s k \bar{u}-j-\emptyset$ (skuj vietā), biežs ledus 175. łpp. (biezs ledus vietā), būt vienis pratīs (ar kädu) 176. lpp. (būt vienis prātis (ar kādu) vietā) u.c. Dažas k|ūdas atkārtojas vairākas reizes, vienā lappusē pat 4 reizes: tulīt (tülìt vietā).

Ir sastopami arī neveikli veidoti teikumi un frāzes: Skolniekiem nav labi büt apceltiem (146. Ipp.), Dzirdëju Almu atbraucam uz Stokholmu (150. 1pp.), Kad Jānis norakstija vēstuli, Sarma atnāca (151. Ipp.), vini sēdēja viens blakus otram (67. Ipp.), ja kas kaut notiek (71. Ipp.), visas šitas manas skaistas pukses (227. Ipp.) u.c.

Arī angliskajā tekstā ir palikušas neizlabotas k]ūdas, piemēram, indefiteness 37. Ipp. (indefiniteness vietā), pariticiples 158. Ipp. (participles vietā), supelative 162.lpp. (superlative vietā) u.c.

Vietumis ne visai precīzs ir latviskā teksta tulkojums anglu valodā: nejēga idiot 40. Ipp. (precīzāk - ignoramus, know-nothing), èdnica - cafeteria 54. lpp. (precīzāk - eatinghouse, canteen), Kaut arī mums būtu tik daudz naudas! - If even we had that much money! 126. Ipp. (precīzāk - If only we had..); Vai jüs man lüdzu atslēgtu šss durvis? - Could you please shut I close this door? 126. lpp. (pareizi - Could you please unlock this door?); Ja sestdien büs skaidrs laiks, mès brauksim uz Jürmalu?

If there will be nice weather on Saturday, we will go to Jürmala 127. Ipp. (precīzāk - If there is nice weather..). 
Sastopami arī daži lietuviešu valodas interferences gadījumi, piemēram, Ja šis velosipēds būtu nupirkts pagājušajā gadā, jis bütu bijis lètāks, nekā tagad (126.lpp.).

Vêl var piebilst, ka viens otrs piemērs ir ar tiešām labu humora izjūtu veidots: vina bija tik skaista, ka man apžilba acis; dod man to smirdošo ābolu - es vinu apēdǐsu (214. Ipp.). Tie neapšaubāmi "atsvaidzina” diezgan sarežg̀ītās latviešu valodas gramatikas skaidrojumus.

Un vēl viens šîs grāmatas pluss ir, ka tã nav tikaj praktiska valodas mācību grāmata, tā ir arī mācību grāmata valodniecībā.

Vērtējot profesora T.Matiasena īso latviešu valodas gramatiku kopumā, var droši teikt, - vajadzīea un noderīea grāmata, ko jau izmanto norvēgu studenti un izmantos aizvien plašāk, un ne tikai studenti Norvēgijā, bet arī citur pasaulē, kur interesējas par latviešu valodu.

Jānis Valdmanis 


\section{IN MEMORLAM}

\section{ANTONINA REKËNA \\ (1928. 13. 08. - 1998. 25. 02.)}

1998. gada 25. februārī mūžĩbā aizgājusi Antoṇina Reķēna valodniece, Liepājas Pedagoğiskās augstskolas profesore, habilitētā filloloǵijas doktore.

Antoñina Reḳ̌ena dzimusi 1928. gada 13. augustā Daugavpils apriṇka Kalupes pagastā. Mācijjusies Āmulu pamatskolā, Daugavpils 1. ǵimnāzijā un Prei|u 1. vidusskolā. No 1948. gada līdz 1952. gadam viṇa studējusi latviešu valodu un literatūru, logìiku un psihologiju Latvijas Valsts Pedagogiskajā institūtā. Vienu gadu A.Rek̨ēna lasījusi psihologijias kursu Cēsu skolotāju institūtā. Un pēc tam viss A.Reḳēnas darba mūžs bija saistīts ar Liepājas Pedagog̉isko augstskolu, kur viṇa kopš 1953.gada lasījusi lekciju kursus psiholog̣ijā, vēsturiskajā gramatikā un dialektolog̣ijā. Gandrīz divus gadu desmitus Antoṇina Reḳēna ir vadījusi augstskolas Latviešu valodas un literatūras katedras darbu. Topošajiem latviešu valodas un literatūras skolotājiem viṇa ir organizējusi mācību praksi dialektologijāa, rosinājusi ieklausīties tautas valodā. Uz dialektologijas praksē savāktā materiāla pamata profesores vadībā ir izstrādāti daudzi kursadarbi, diplomdarbi, bakalaura un magistra darbi, kas ir tālāk izmantojami valodnieku pētījumos.

Antoṇinas Reḳēnas zinātniskais darbs sakṇojas dzimtajā Latgalē - Kalupes un tās apkārtnes izloksnēs. Jau 50. gados viṇa, studiju biedrenes valodnieces Silvijas Rages mudināta, ir sākusi pierakstīt Kalupes izloksnes, vēlāk arī kaimiṇizlokšņu - Lỉksnas, Nīcgales un Varkavas leksiku. Gadu gaitā A.Reķēna ir savākusi loti bagātu izlokšnu materiālu, kas ir sistematizēts, apkopots un analizēts apmēram 50 zinātniskās publikācijās.

A.Reḳēnas pirmais plašākais darbs kandidāta disertācija ir veltīts Kalupes izloksnes fonētikai un morfologijai, tajā jetverts arī neliels izloksnes vārdu krājums 
(Kalupes izloksne. Fonētika. Morfologija. Leksika. - Filologijas zinātṇu kandidātes disertācija. Liepājā, 1962). Kalupes izloksnes izpētei dažādos aspektos A.Reķēna ir pievērsusies arī daudzās citās publikācijās: "Nomenu piedēk|i un izskaṇas Kalupes izloksnē" (Liepājas Pedagogiiskā institūta raksti, 4. sēj.

Rīga, 1960. - 415.-441. !pp.), "Saik|i Kalupes izloksnē" (Turpat. - 405.-414. Ipp.), "Semantiskie dialektismi Kalupes izloksnes leksikā" (Latviešu valodas teorijas un prakses jautājumi. Rīga, 1967. 94.-102. lpp.), "Aizguvums semantikas diferencētājs" (Baltistica III (1) priedas. - Vilnius, 1989. 173.-178. Ipp.), "Par augšzemnieku dialekta Kalupes izloksnes priedēk|verbu semantiskajām atšķirībām no latviešu literārās valodas" (Valodas aktualitātes-1984. - Rīga, 1985. 87.-97. Ipp.), "Lokālo un internacionālo aizguvumu fonētiskā asimilācija augšzemnieku dialekta Kalupes izloksnē" (Fonētikas un fonologijas aktuālās problēmas. Artura Ozola diena. Zinātniska konference. Referātu tēzes. - Rīga, 1968. - 68.-73. lpp.) u. c.

Jau zinātniskās darbības sākumposmā Antoṇinas Rekēenas uzmanỉbas lokā ir valodu kontaktu izpēte, jo Dienvidlatgale vienmēr ir bijis daudznacionāls novads. Raksturīgākie valodas fakti, kas liecina par austrumslāvu valodu ietekmi Kalupes un citu Dienvidlatgales izlokšņu fonētikā, morfologijiā un leksikā, ir aplūkoti, piemēram, rakstos "Par dažiem jautājumiem, kas rodas sakarā ar augšzemnieku dialekta Kalupes izloksnes pētījumiem" (Latviešu valodas teorijas un prakses jautājumi. Rīga, $1967 . \quad 66 .-80$. lpp.), "Latviešu valodas un slāvu valodu sakaru izpausme Kalupes izloksnes zemkopïbas leksikā" (Latviešu valodas un literatūras problēmas. - Rīga, 1970. 166.-174. Ipp.), "Slāvismi Latgales dienvidu izlokšņu èdienu leksikā" (Dialektālās leksikas jautājumi, 2.sēj. Riga, 1986. - 57.-96. Ipp.).

Plašākais pētijums latviešu valodniecībā par Latgales dienvidizlokşnu un slāvu valodu sakariem ir 1975. gadā publicētā apjomīgã monogrāifija "Amatniecības leksika dažās Latgales dienvidu izloksnēs un tās sakari ar atbilstošajiem 
nosaukumiem slāvu valodās" (Rīga, 1975. 707 lpp.), kurā amatniecības nosaukumi ir analizēti etimolog̀iskā, areālā, vārddarināšanas, kā arī etnogrāfiskā aspektā. Lingvistiskie dotumi tajā ir aplūkoti ciešă saistībā ar vēstures un etnogrāfiskām ziṇām un atklāj amatniecības leksikas dinamiku. Par šo darbu A.Rek̦ēnai 1978. gadā piešḳirta J.Endzelīna balva valodniecībā.

Dažās publikācijās (līdzās slāvu valodu ietekmes izpētei) ir analizēti arī latviešu un lietuviešu valodas lingvistiskie sakari Dienvidlatgales izloksnēs; piemēram, rakstā "Priedēk|a $d a$ - un palīgvārda $d a$ nozīmes un lietojums augšzemnieku dialekta izloksnēs salīdzinājumā ar lietuviešu valodu un slāvu valodām" (Latviešu valodas teorijas un prakses jautājumi. - Rìga, 1967.

81.-93. Ipp.). Valodu sakarus A.Reḳēna ir pētījusi arī toponīmiskajā materiālā, piemēram, rakstā "Latviešu valodas sakari ar-lietuviešu valodu un slāvu valodām Kalupes toponīmu atspogulojumā" (Latviešu valodas un literatūras problēmas. Rìga, 1970. - i52.-165. lpp.).

Dienvidlatgales izlokšṇu un lietuviešu valodas paralēju apzināšanai un analīzei dažādos valodas līmeṇos Antoṇina Reķēna îpaši pievērsās pēdējā desmitgadē. Par šo tēmu bija iecerēta monogrăfija, bet līdz lasītājam nonāca tikai dažas publikācijas: "Dienvidlatgales izlokšṇu un lietuviešu valodas paralēles vārddarināšanā" (Baltistica XXXI (1). - Vilnius, 1996. - 53.-70. Ipp.), "Dienvidlatgales izlokšnu un lietuviešu valodas leksiski semantiskās paralēles ar atmosfēru saistītajos nosaukumos" (Vārds un tā pētīšanas aspekti. - Liepāja, 1997. 97.-108. Ipp.).

Par darbu kopu "Dienvidlatgales izlokšņu leksika" Antoṇinai Reḳēnai 1993. gadā piešķirts filologijas habilitētās doktores zinătniskais grāds.

Profesore A.Rekēena ir aplūkojusi arī dažādām latviešu izlokšṇu grupāmn kopīgas parādības, piemēram, rakstā "Verbu formu paralēles latgaliskajās, Zemgales sēliskajās un kursiskajās izloksnēs" (Latvijas Zinātnuu Akadēmijas Vēstis. A daḷa. - 1995. - Nr. 3/4. - 14.-23. Ipp.), balstoties uz analizêtâ materiāla, viṇa 
pievienojas valodnieku (piemēram, J.Endzelīna, A.Breidaka) atziṇai, ka zināmās kopīgās valodas izoglosas nav nejaušỉba, bet tãs atspogu|o dialektu senās attiecibas un liecina par latga|u, sēju un kuršu cilšu kontaktu iespēju tālā pagātnē.

A.Rekēnas uzmanību ir saistijušas arī pārmainasas mūsdienu latviešu izloksnēs. Piemēram, rakstā "Mūsdienu lauksaimniecības leksikas attīstỉbas galvenās tendences latviešu valodas izloksnēs" (Baltu valodas senāk un tagad. - Rīgā, 1985.

72.-79. Ipp.), pamatojoties uz dažădu izlokšṇu grupu dotumiem, ir secināts, ka lauksaimniecības leksikas attīstība izpaužas vairākos virzienos: literārās leksikas apguvē, krievisko un internacionālo aizguvumu pārṇemšanā, jaunu nominācijas vienību izveide, vārdu variantu un paralēlnosaukumu lietojuma paplašināšanā.

Ar vairākām publikācijām A.Rek̦ēna ir iesaistījusies latviešu dižākā dzejnieka Raiṇa Gētes "Fausta" atdzejojuma izpētē. Viṇa ir izsekojusi tulkojumā sastopamajām vairākām verbu formu īpatnībām, kā arī leksikai, kas sakṇojas Dienvidlatgales izloksnēs, piemëram, rakstos "Verbu formu īpatnības J.V.Gētes "Fausta" atdzejojumā" (Baltu filologija.

Rīga, 1995. - 63.-72. Ipp.), "Dialektālā leksika Gētes "Fausta" atdzejojumā" (Valodas aktualitātes - 1987. - Rīga, 1988. - 21.31.lpp.), "Apvidvārdu lietojuma ippatnibas "Fausta" atdzejojumă" (Raiṇa gadagrāmata. - Rīga, 1988. 86.-113. Ipp.).

Profesores rūpīgi vāktais un sagatavotais Kalupes un kaimiņizlokšṇu materiāls ir iek]auts arī geolingvistiskajos darbos - "Latviešu valodas dialektu atlantā" un starptautiskā izdevumā "Eiropas valodu atlants" (Atlas Linguarum Europae).

A.Reķēna ar referātiem par dažādiem Dienvidlatgales izlokšṇu jautājumiem ir piedalījusies daudzās valodnieku konferencēs un kongresos Liepājāa, Rīgā, Tartu, Vilṇã un citur.

Vislielākais Antoṇinas Reķēnas ieguldījums valodniecībā ir viṇas mūža darbs divsējumu "Kalupes izloksnes vārdnīca" (1998. g.). Tã ir bagāts faktu avots tālākiem pētījumiem valodniecībā, salīdzinājumam ar kaimiṇizlokšṇu un kaimiṇtautu valodām dažādos līmeṇos. 
Ir aizvadīts darbīgs un bagāts mūžs. Tas ir ierakstījis neizdzēŠamu lappusi Dienvidlatgales un visas Latvijas kultūrvēsturē.

Brigita Bušmane 


\section{JURIS RIN̦KIS \\ 24.01.1931. - 22.06.1998.}

Vārds izskan, bet tā grafiskais attēls dzīvo mūžos. Mākslinieka têlainä doma materializējas gleznā, skulptūrā, grafikas lapā un rosina. informē un priecē arī tad, kad tās radītāja šāszemes gaitas ievijušās aizsaules ce|os.

Ik reizes, kad ṇemu rokās mūsu institūta žurnālu "Linguistica Lettica" un vēroju tā māksliniecisko apdari un iekārtojumu, kad redzu Latviešu valodas institūta veidlapas un dokumentus, ko rotā atvērtā grāmata ar simbolisko saules loku institūta nosaukumā, jādomā par mākslinieku Juri Riṇkgi, ar kuru institūtam bija veiksmīga sadarbība kopš institūta dibināšanas 1992. gadā. Visas pasaules baltu valodu pētnieki iepazinās ar Jura Riṇķa veidoto VII Starptautiskā baltistu kongresa plakātu un kongresa atribuitiku, kuras mākslinieciskā vienotība radīja lietišķu un vienotu noskaṇu.

Juris Riṇkis bija viens no darbīgākajiem un veiksmīgākajiem pēdējo gadu desmitu latviešu lietišķās mākslas meistariem, arī prasmīgs mākslas izstāžu organizators un kritiķis. Ar saviem darbiem viṇš piedalījies vietējās izstādēs, Austrumeiropas plakātu triennālēs Varšavā un lietišḳās grafikas triennālēs Brno, gūdams labus panākumus. Ilgus gadus varēju vērot vina darbus Pārtikas rūpniecības ministrijas Mākslas padomēe, kad tiem laikiem atbilstošo iespēju ietvaros ar Jura Riṇka radošo izdomu mūsu rūpniecības produkcija ieguva tīkamu māksliniecisko ietērpu. Loti noderīgi bija viṇa konkrētie, lietišķie ieteikumi kolēğu darbam, arī vērīgie aizrādījumi par tekstu valodu.

Vasaras pilnbriedā aprāvusies talantīgā grafiḳa dzīves līnija. Taču tās līnijas, ko Juris Riṇķis ievilcis latviešu grafikas mākslā, piešķirot skaistumu arī ikdienišķajam, ir paliekamas. Viṇu vienmēr piemiṇā paturēs arī Latviešu valodas institūta darbinieku sainne. 


\section{HRONIKA}

\section{SESTO REIZI VILN⿳亠̄⿵}

1997. gada 7.-9. oktobrī Vi|ṇā notika VIII Starptautiskais baltistu kongress "Baltu valodas 16. un 17 gadsimtā", kas šoreiz bija veltīts pirmās lietuviešu grāmatas Martīna Mažvĩda katehisma - 450 gadu atcerei.

Baltistu saietu sākotne meklējama 1964. gadā, kad Vilṇas universitātes Lietuviešu valodas katedras un Lietuviešu valodas institūta darbinieki sarîkoja pirmo baltistu konferenci. Pēc gada nāca klajā pirmais žurnāla "Baltistica" numurs, un tika nolemts pulcēties konferencēs, kas vēlāk pārauga kongresos, ik pa pieciem gadiem. Šī tradīcija tika pārkāpta tikai 1991. gadā, kad Vi|ṇā notika VI Starptautiskais baltistu kongress, kuru nācās uz gadu atlikt politiskās situācijas nestabilitātes dē]. Lielākā da|a līdzšinējo kongresu ir notikusi Vịṇā, tikai divus - 1980. gadā Rīgā un 1995. gadā Jūrmalā (Lielupē) - ir organizējuši latviešu valodnieki. Arī šis astotais bija ārkārtas kongress, kuru organizēja lietuviešu kolēgi, uzskatot, ka pirmās lietuviešu grāmatas klajā nākšanas gadadiena ir pietiekams iemesls, lai pulcinātu kopā visas pasaules baltistus. Tas noteica arī kongresa tēmas izvēli - pievēršanos lingvistikas vēstures problēmām gan sinhroniskā, gan diahroniskā aspektā.

Un tā VIII Starptautiskais baltistu kongress "Baltu valodas 16. un 17. gadsimtā" pulcēja dalībniekus no 13 valstīm Lietuvas, Latvijas, Krievijas, Ukrainas, Vācijas, Polijas, Somijas, Norvēg̀ijas, Igaunijas, Šveices, Itālijas, Nīderlandes un ASV

Kongresa dalïbniekus sveica Lietuvas Republikas Seima priekšsēdētājs Vîtauts Landsberğis, novēlot, lai pievēršanās valodas un tautas kultūras izpētei palīdzētu saglabāt Atmodas "simbolikas" vienotību.

Pēc Vilṇas universitātes rektora profesora Rolanda Paviḷoṇa ievadvārdiem sākās kongresa darba, kas bija organizēts divăs plenārsēdēs un piecu sekciju sēdēs. 
Pirmo referātu par reformācijas kustību Baltijā un tās rezultātā radušos Martīna Mažvīda katehismu (1547) nolasīja R.Ekerts /R.Eckert/ (Vācija). Arī toreizējais Lietuvas republikas Izglītības, zinătnes un kultūras ministrs $\underline{Z}$.Zinkevičs pievērsās M.Mažvīda rakstu valodas avotiem. G.Mihelini /G.Michelini/ (Itālija) uzskatāmi nodemonstrēja, kuras un cik no M.Mažvīda katehismā ietvertajām dziesmām ir latīniskas cilmes. Savus pētījumus viṇš salīdzināja ar D.Počūtes monogrāfijas "XVl XVII a. protestantų bažnytinès giesmès" (16. -17. gs. protestantu baznīcas dziesmas), kas iznāca Vi|ṇa 1995. gadā, datiem. $\underline{\text { K}}$. Kuzavina un A. Girdena pētijums "Kelios mintis dèl baltu vardažodžio kirčavimo paradigmnu ir jų raidos" tā bija atgriešanās pie nomenu akcentologijijas, îpašu vērību veltot šĩs parādības attīstībai un paradigmâm.

"FONETTIKAS, FONOLOĢIJAS UN AKCENTOLOĢIJAS" sekcijas divās sēdēs tika nolasīti 11 referāti. Arī šis kongress pierādīja, ka fonētika un fonologija ir lietuviešu valodnieku prioritārais pētījumu virziens, jo sekcijā viṇu pārsvars ( 8 referāti) bija pamanāms uzreiz.

V.Čkmons balstoties uz lingvoǵeogrāfiskajiem un tipoloǵiskajiem pētījumiem analizēja austrumbaltu *uo,

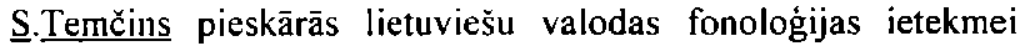
vārddarināšanas procesā, O.Polakovs aplūkoja jēdziena "fonētiskie likumi" dažādās izpratnes sākot ar klasisko salīdzināmo valodniecību. D.Mikulēniene, izmantojot "Lietuviešu valodas atlanta" materiālus, aplūkoja cirkumflektētās metatonijas gadījumus salikteṇos. $\underline{\text { R.Derksens }}$ /R.Derksen/ (Nīderlande) pieskārās patskaņu maiṇas gadījumiem anonīma autora 1605. gada lietuviešu katehismā, bet V.Lazauskaite $u$-celma adjektīvu un to atvasinājumu ar piedēkli -umas cilmei. A. Girdenis aplūkoja senajos rakstos sastapto patskaṇu ar nazalizācijas zīmi attīstības paradoksus, bet

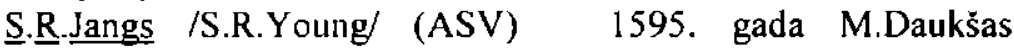
katehisma akcentogrāfiju. B. Stundža pievērsās baltu senās vārddarināšanas sistēmas rekonstrukcijas iespējām un ar to saistītajām problēmām. P. Vanags informēja par to fonologisko 
sistēmu, kas bija sastopama latviešu valodā 16. gs., bet ㄸ. Garšva

par Linkuvas izloksnes fonētikas galvenajām attīstības tendencēm.

"MORFOLOGIJAS UN SINTAKSES" sekcija bija vienīgā, kurai tika veltītas trīs sēdes un nolasīti 18 referāti. Morfoloğijas problēmas tika skatītas gan sinhroniskā aspektā vecākajos lietuviešu un latviešu rakstu avotos, gan arī diahroniskā aspektāa, salīdzinot ar mūsdienu situāciju un dažādu kontaktvalodu dotumiem. Par morfologijas un sintakses problēmām bija gatavi diskutēt ne tikai lietuviešu un latviešu valodnieki, 'bet arī daudzie viesi, kuru skatījums bieži bija visai neparasts, taču rosinošs.

Pirmajā sēdē tika aplūkotas gramatiskās konstrukcijas senākā posma rakstu avotos: $\underline{\text { A. }}$ Rosins informēja par

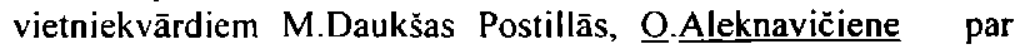
lokatīva locījuma tulkošanas iespējām J.Bretkūna Lukas evaṇgèlijāa L.Leikuma - par verba formām pirmajā saglabātajā latgaliešu grāmatā "Evangelia toto anno...", A. Stafecka - par īpatnībām (lietvārdu izskaṇas, locījumu galotnes, atgriezeniskais formants, kondicionā|a formas) senākā posma latgaliešu rakstos, K. Pokrotniece izvērtēja salikta teikuma da|u saistījuma veidus pirmajā katolı katḳismā, bet E. Liparte văcu valodas partikulverbu atveidi $G$. Mance|a darbos.

Otrā sekcijas sēde sākās ar kontrastīvās morfologijas problēmu apskatu. D. Edelmane (Krievija) aplūkoja atsevišķas irāṇu, baltu un slāvu kopīgās izoglosas, V. Mančaks /W.Mańczak/ (Polija) - formanta *-m- vēsturi un attīstību baltu, slāvu un g̀ermāṇu valodā, $\underline{\text { A. Holvuts }}$ /A.Holvoet/ (Polija) infinitīva veidus baltu un slāvu valodās. Sēdes turpinājumā tika nolasīti divi referāti, kas skāra verbu attīstību lietuviešu valodā: E. Bukevičūte (Vācija) runāja par verbu divskaitla lietojumu 1735. gada J.J.Quandto bïbelē, bet N..Ostrovskis N.Ostrowski/ (Polija) pieskārās lietuviešu valodas verbu pláuja, ráuja, káuja izcelsmei kā gramatiskāa tā arī semantiskā aspektā. D. Kiselūnaite savā ziṇojumā skāra kursenieku valodas īpatnības sākot no A.Becenbergera reg̉istrējumiem līdz mūsu dienām. 
Trešā sekcija sēde sākās ar senprūšu valodas apskatu: A. Kaukiene analizēja prūšu valodas verbu struktūras īpatnības, F.Kortlands /F.Kortlandt/ (Nĩderlande) pievērsās senprūšu katehisma valodas îpatnībām grmatiskajā aspektā. D.Pakalniškiene aplūkoja verbu skaṇu infiksus kā seniskus patskaņu mijas reliktus. A. Andronovs (Krievija) skāra vienas izteiksmes - vajadzības izteiksmes - vietu un nozīmi latviešu valodas gramatiskajās tradīcijās sākot ar Rehehūzena gramatiku. A.Timuška pievērsās komparatīvkonstrukciju salīdzinoši vēsturiskajai analīzei. Vēl šajā sekcijā tika nolasīts arī programmā neiek|autais B. Reidzānes referāts "Vārdkopu semantika latviešu tautasdziesmās"

Programmā bija ieklauti, bet netika nolasīti divi referāti:

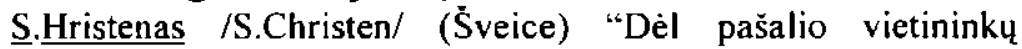
M.Daukšos "Postileje"" un S.Lagzdinas "Refleksīvie verbi un refleksīvās konstrukcijas 16. un 17. gs. latviešu rakstu valodā"

"LEKSIKOLOGIJAS UN LEKSIKOGRĀFIJAS" problēmām tika veltītas divas sēdes, kurās nolasīja 11 ziṇojumus. Referātos tika skatītas dažādas tèmas, taču tās visas tā vai citādi bija saistītas ar lietuviešu un latviešu rakstu valodas senāko posmu.

Sekcijas pirnajā sēdē A. Blinkena raksturoja G.Mance|a vārdnīcā "Lettus" (1638) iekJautos adjektīvus pēc to semantikas un gramatiskajiem kritērijiem, A. Nepokupnijs (Ukraina) pieskārās vārda 'grāmata' deminutīiva formu lietojumam lietuviešu un senprūšu valodā, uzskatot to par nostiprinājušos tradīciju jau 16.gs., kas varētu būt saistīta ar Prūsijā lietotās vācu valodas leksikas savdabību. $\underline{\text { V.Drotvins }}$ analizēja M.Mažvīda rakstos un 17. un 18.gadsimta Mazās Lietuvas vārdnīcās ieklautos svešvārdus. B. Velhli /B.Wälchli/ (Šveice) aplūkoja latviešu un lībiešu valodas leksisko nozīmju tuvināšanos un tās nozīmi baltu valodu klasifikācijā. $\underline{S}$.Ambrazs un $\underline{V} . \underline{\text { Zinkevičs }}$ pievērsās lietuviešu veco tekstu datorizācijas problēmām un iespējām izveidot datorizētu lietuviešu valodas vēsturisko vārdnīcu. G. C.Čepaitiene pieskārās vēlējuma izteiksmes nozīmei M.Mažvīda rakstos. 


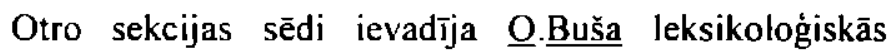
pārdomas par Grūnava tēvreizi un leksikologiski apstiprinātais pieņēmums, ka Grūnava tēvreizes teksts ir "latviešu valodas teksts, ko ietekmējusi kuršu valoda" vai vēl precīzāk, Grūnava tēvreizē ir skaidri pamanāms rietumbaltu substrāts vai adstrāts. A.Bankavs, pēc Bezansonas Francijas Nacionālā zinātnisko pētījumu centra rīcībā esošās informācijas, aplūkoja etnonīmu latvietis, lietuvietis, igaunis registrāciju franču valodas tekstos sākot ar 15.gs. pirmo pusi. 1.Jansone analizēja 17.gs. latviešu valodas vārdnīcās fiksētos apgèerba nosaukumus semantiskā un morfologiskā aspektā. N.Čepiene pievērsās J.Bretkūna bỉbelē

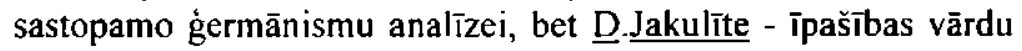
apskatam "Knygos Nobažnystès"

Diemžêel uz kongresu nebija ieradies A. Breidaks, tādē] viṇa pieteiktais referāts "Zieme|latgales izlokšṇu nominālo, pronominālo un verbālo galoț̣u $-e,-o$ vēsture" palika nenolasīts.

"ETIMOLOGIIJAS UN ONOMASTIKAS" sekcijas divās sēdēs tika nolasīti 11 referāti. Šai sekcijā nolasītie ziņojumi lielākoties skāra konkrētu vārdu (etnonīmu, teonīmu, dialektismu u.tml.) cilıni.

Pirmajā sēdē ZZZ.Zinkevičs aplūkoja 17.gadsimta muižu inventarizācijas sarakstos sastopamos personvārdus $k \bar{a}$ vienu no antroponīmikas un demogrāfijas izpētes avotiem, N. Mikhailovs NN.Mikhailov/ (Itālija) pievērsās baltu teonīmu analīzei J.Lasicka darbā "De diis samagitarum", kas sarakstīts 16.gs. beigās,

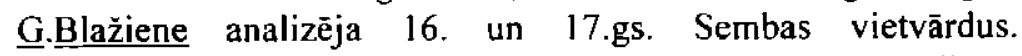
S. Kara|ūns piedāvāja jaunu etnonīma jātvingi cilmes skaidrojumu, bet K. Liukonens /K.Liukkonen/ (Somija) izteica savas domas par dažu etnonīmu (balti, aisti, lietuvieši, galindi) cilmi. Šis sekcijas sēdes darba kārtībā tika ieklauts arī V.Smočinska (Polija) referāts par dažiem vācu izcelsmes senprūšu verbiem.

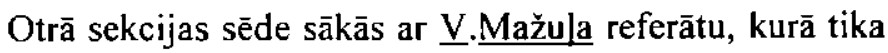
analizēta leksēmu ābele un äbols izplatība baltu un slāvu apdzīvotajās teritorijās. $\underline{\text { P. }}$ U. Dini (Itālija) apcerēja baltu valodniecības vēstures (Historiographia Linguistica Baltica) 
nepieciešamību un nozīmību. E. Kagaine izteica hipotēzes par dažu dialektālo vārdu (korpi, kotika, kizika. loicka) iespējamo

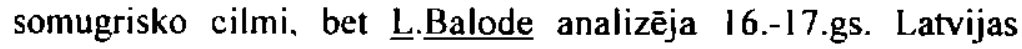
kartēs fiksētos hidronīmu nosaukumus. L.Vaba (Igaunija) aplūkoja skaṇu pārmaiṇas $(k \grave{s} \rightarrow h)$ igauṇu valodā no baltu valodām aizgütajos vārdos.

Šai sekcijā tika pieteikts arī $\underline{\text { V.Toporova (Krievija) }}$ referāts "Из старолитовского мифологического ономастикона (Chaurirari)" un K. . Ščsı̣akas /K.Szcześniak/ (Polija) referāts "Names of settlements on the contemporaly maps"

"RAKSTU VALODAS" problēmām bija veltītas divas sēdes, kurās nolasīja 11 referātus, kas raksturoja latviešu un lietuviešu rakstu valodas sākumposmu gan sinhroniskā, gan diahroniskā aspektā.

Sekcijas pirmo sēdi ievadīja $\underline{J} . \underline{\text { D.Ranges }}$ (Vācija) referāts par labojumiem Bretkes bïbelē, kurus veicis Daniels Gallus. J.Palonis analizēja Volfenbūtela postillu (1573) saistību

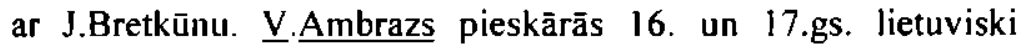
tulkotajai literatūrai, aplūkojot to kā vēsturiskās sintakses avotu. G. Kavalūnaite analizēja, kā holandiešu avoti ietekmējuši Boguslava Hīlinska Jaunās Derības tulkojumu, bet O.Aleknavičiene mēgināja noteikt J.Bretkūna Postillu atsevišķu da|u autorības jautājumus. G. . Subačs aplūkoja B.Gaileviča ieguldījumu reliğisko rakstu tulkošanā.

Sekcijas otrajā sēdē nolasītajos referātos tika sasaistīti 16.un 17.gs. baltu valodās pastāvošie procesi ar mūsdienām. V.Porina aplūkoja 17.gs. latviešu rakstu vērtējumu 20.gs. valodniecības vēsturēe, $\underline{V}$.Ernstsone salīdzināja 17.gs. latviešu

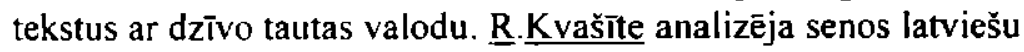
lietišksos tekstus un to ietekmi uz lietišḳo tekstu tālāko attīstības vēsturi. J.Rozenbergs sniedza ieskatu latviešu literārās valodas veidošanās apstākḷos un ar tiem saistītajās problēmās,

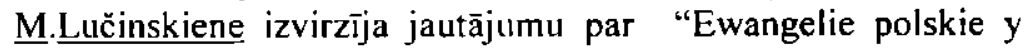
litewskie" piederību lietuviešiem vai poliem.

Netika nolasīti divi paredzētie referāti: $\underline{J} . \underline{\text { Sillis }}$ "Sociolinguistic functions of the $16^{\text {th }}$ and $17^{\text {th }}$ c. Latvian 
language existence forms", J.Pavela /J.Pawela/ (Polija) "G.Elgerio žodyno "Dictionarivm Polono-Latino-Lottauicum" (1863) vaidmuo latviu kalbos standartizacijos procese"

Noslēguma plenārsēdè tika nolasīti četri zinnojumi, kuros skartās problēmas pārsniedza vienas sekcijas robežas.. V.P.S.Śmids /W.P.Schmid/ (Vācija) turpināja 1872. gadā aizsākto diskusiju par Baltiju kā indoeiropiešu valodas centru. Savu teoriju viṇš balstîja uz baltu cilmes hidronīmu analīzi. Arī J.Otkupškikovs (Krievija) izmantoja hodronīmus baltu areāla noteikšanai Okas upes baseinā. T.Matiasens /T.Mathiassen/ (Norvēgija) analizēja lietuviešu un latviešu valodniecības terminus, uzsverot kopīgo un norādot uz atšḳirīgo. I.Druviete pievērsās lingvistiskās situācijas analīzei Latvijā 16 . un 17.gadsimtā.

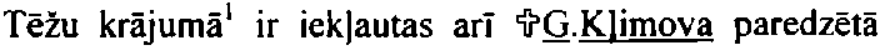
referāta "On some extra-indo-european parallels of baltic vocabulary" tēzes.

Kongresa oficiālo darba kārtỉbu papildināja dažādi vairāk vai mazāk oficiāli pasākumi, tostarp pieṇemšana Latvijas Republikas vēstniecībā Lietuvas Republikā, ko organizēja vēstnieks A.Sjanits, un konferences noslēgums Vilṇas universitātê, kuru kuplināja senās mūzikas ansamblis.

Īpaši gribētos atzīmēt grāmatu pēcpusdienu, kurā savus izdevumus prezentēja ne tikai Lietuvas valodnieki, bet arī konferences viesi. Tā bija lieliska iespēja iepazīties ar baltistikas nozīmīgākajām grāmatās, kas nākušas klajā kopš iepriekšèjā kongresa 1995. gadā. Patīkami, ka atkal ir papildinājies valodniecības periodisko izdevumu klāsts un šoreiz tas ir mūsu žurnāls "Linguistica Lettica"

VIII Starptautiskais baltistu kongress ir izskanējis ar savām domām, vērojumiem, salīdzinājumiem, lai teiktu:

"Uz tikšanos Rīgā IX Starptautiskajā baltistu kongresā 2000.gadā"

Ilga Jansone

\footnotetext{
1 VIII Starptautiskā baltistu kongresa "Baltu valodas XVI un XVII gadsimtā" referātu tēzes 1997.g. 7.-9.oktobrî. Vilnaa, 1997.
} 


\section{ZINĀTNISKĀ KONFERENCE \\ "VĀRDS UN TĀ PĒTİ̌̆ANAS ASPEKTI" LIEPĀJĀ}

Liepājas Pedagogijas akadēmijā 1997.gada 28.novembrī notika jau otrā zinātniskā konference "Vārds un tā pētī̌anas aspekti" LPA Latviešu valodas un literatūras katedras valodnieki šādu konferenci iecerējuši organizēt katru rudeni, sadarbojoties gan ar Latvijas, gan ar Lietuvas kolëgiem (1996.g. pirmajā konferencē piedalījās Klaipēdas Universitātes prof. A.Kaukiene un doc. D.Pakalnišķiene).

Konferences plenārsēdē un divās sekcijās tika nolasīti 24 referāti.

Plenārsēdi ievadīja I. Druvietes (Rīga) referāts "Valodas likumi Latvijā: sociolingvistiskais un politiskais aspekts", kurā tika analizētas valodu attiecības un valodas politika Latvijā, uzsverot, ka lingvistiskās likumdošanas būtība mūsu valstī ir radīt mehānismu latviešu valodas noturībai, aizsargāt to no asimilācijas draudiem, vienlạikus nodrošinot iespēju noteiktās funkcijās lietot arī minoritāšu valodas. A. Timuška (Rīga) raksturoja Eiropas valodu atlanta un tajā iek|auto latviešu izlokšñu materiālu nozīmi geolingvistikas un valodu tipologijas pētījumos. Lielu klausītāju interesi, kā arī diskusijas radīja I.Zuicenas (Rīga) referāts par "Mūsdienu latviešu valodas vārdnīcas" projektu; klausītājiem bija iespēja iepazīties ar šīs vărdnīcas šḳirklu paraugiem. A. Bankava (Rīga) referāts atgādināja par 1878.gadā Liepājā izdoto pirmo latviešu valodas svešvārdu vārdnīcu - F.Mekona "Svešu vārdu grāmatu"

Sekciju "Leksikologijjas un leksikogrāfijas problēmas" vadīja O.Bušs un V.Strautina. Dala sekcijā nolasīto referātu bija veltīta izlokšņu leksikas un toponīınijas studijām. E. Kagaine (Rīga) analizēja dažu Inazāk aplūkotu Baltijas somu valodu aizguvumu (piem., jẹka un tā atvasinājumu jẹâ̄t, piejẹkāt, sajękāt, jẹkalis, jẹkājums) semantiku un tās attīstību Zieme|vidzemes pierobežas izloksnēs. $\underline{\text { B }}$ Laumane (Liepāja) 
raksturoja izloksnēs sastopamo vardes un krupja dažādo nosaukumu rašanās motivāciju un izplatību. A. Stafecka (Rīga) iepazīstināja ar jēdziena pērkons rüc leksiski semantisko realizāciju dažādos Latvijas novados. $\underline{\text { O.Bušs }}$ (Rīga) analizēja vietvārdu ar sakni $R \bar{u} c$ - izplatību, notādot uz šo vietvārdu etimologiiskajām saiknēın ar vairākām vārdu ligzdām. Leksikogrāfijas jautājumiem bija veltīts $\underline{\text { M.Stengrevicas (Rīga) }}$ referāts "Vārds leksikogrāfijā̄" un II.Jansones (Rīga) referāts "Semantisko pārmaiṇu atspogulojums vārdnīcās" V. Kuzina (Rīga) iepazistināja ar dažādu funkcionālo stilu leksisko minimumu .izstrādi Latvijāa, bet $\underline{V}$.Ernstsone (Rīga) analizēja sarunvalodas leksikas izmantojumu reklāmas tekstā, atzīstot to par mūsdienu reklāmas nozimīgu un ietekmīgu elementu. R. Makare (Rīga) runāja par vārda pētī̌sanas veidiem un nozīmi skolā, uzsverot atziṇu, ka vārda iepazīšanai jānotiek visā valodas un literatūras apguves procesā, ne tikai šim jautājumam programmā paredzētajās stundās. ZZ.Ikere (Daugavpils) referātā "Vārdi un to nozīme latviešu tradicionālās kultūras "semantiskajā laukā"”" aplūkoja latviešu folkloras tēlu sistēmas, kas valodas līmenī izteiktas ar tradicionālām frāzēm un latvietī izraisa īpašas kultūras asociācijas, taču sveštautiešiem var būt nesaprotamas. 1.Pūtele (Rīga) tautasdziesmas izmantoja kā darītājvārdu un seno amatu nosaukumu avotu; referătā tika analizēti darītājvārdu atvasināšanas mode|i, kā arī šīs tematiskās grupas mantotās un aizgūtās leksikas attiecības.

Sekciju "Fonētikas, morfologijas un sintakses problēmas" vadīja A.Bankavs un M.Beitina. J.Rozenbergs (Rīga) referātā "Vārda pētīšanas aspektu aktuālās problēmas" akcentēja vārda stilistiskās izpētes nozīmi. Vairāki Liepājas valodnieku referāti bija veltīti līdz šim maz pētītiem sintakses jautājumiem. M.Beitina (Liepāja) raksturoja verba vajadzēt ienākšanas procesu latviešl valodā, tā formu un sintaktiskās apkaimes variantus rakstu valodā no $16 . \mathrm{gs}$. līdz mūsdienām.

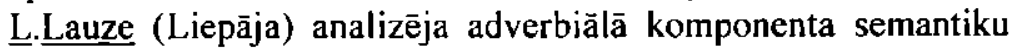
un realizāciju latviešu sarunvalodas sintaksēe, bet $\underline{D}$. Baltaiskalna (Liepāja) Ķikula Jēkaba "Dziesmu" sintaktisko izveidi. 
A. Tîsina (Rīga) referēja par okazionālajiem krāsu nosaukumu salikteņiem latviešı valodā. A.Kalnača (Rīga) analizēja verba laika un modalitātes mijiedarbību darbības vārda izteiksmju formās. ㅂ. Busšmane (Rîga) referātā, kas izstrādāts pēc Latviešu valodas diaiektu atlanta leksikas da|as materiāliem, atklāja lietvārdu celmu formu daudzveidību un variantus latviešu izloksnēs. M․ Poiša (Rīga) raksturoja augšzemnieku dialekta sēlisko izlokšnu verbus, kas atvasināti ar priedēkli aiz-, izcelot atvasinājumu semantiskās grupas, kas literārajā valodā nav raksturīgas. Kvantitatīvās lingvistikas nozarē bija izstrādāts

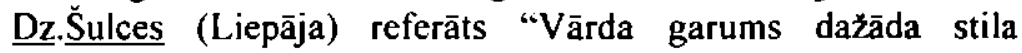
tekstos"

Gan plenārsēdē, gan abās sekcijās nolasītie referāti izraisīja kolēğu jautājumus ụn diskusijas. Ieințeresēti klausītāji bija arī LPA filologijas studenti, magistranti, doktoranti, Liepājas skolotāji. Nolasīto referātu tēzes ieklautas konferences tēžu krājumā, pēc konferences referātiem un citiem materiāliem tiek veidots rakstu krājums.

leva Ozola

\section{VALODA UN TĀS ELEMENTI}

Par vienu no nozīmīgākajiem latviešu valodniecỉbas akadēmiskajiem forumiem uzskatāmas gadskārtējās akadēmiḳa Jāṇa Endzelīna dzimšanas dienas atceres zinātniskās konferences, ko tradicionāli organizē Latviešu valodas institūts. Šogad, izcilā valodnieka 125 . jubilejas reizē, konferences programma bija ipaši plaša (pieteikti 47 referāti). Tā jau 20. februārī konferences dalībnieki godināja J.Endzelīna piemiņu viṇa pēdējā atdusas vietā Raiña kapos, bet konferences darbs ritēja divas dienas -23 . un 24. februārī.

Pirmajā plenārsēēe konferenci oficiāli atklāja Latviešu valodas institūta direktors Jānis Valdmanis, īsi raksturojot ieguvumus un zaudējumus latviešu valodniecībā aizvadītajā gadā. Vairākos darba gaitā nolasītajos referātos tika izvērtēts 
J.Endzelīna devums resp. mantojums: Ojārs Bušs iepazīstināja ar J.Endzelīna un citu autoru jaunvārdiem Ed. Ozoliṇa "Vāciskilatviskā vārdnīcā", Valentīna Skujina - ar terminu modeliem J.Endzelīna caurlūkotajā elektrotehnikas vārdnīcā, Ina Druviete

ar K.Mīlenbaha tradīciju latviešu valodniecỉbas vēsturē. Praktiskā skatījumā interesanti bija atsevišksām tēmām veltītie pētijumi: Benita Laumane (Liepāja) aplūkoja tautas dziednieku un zintnieku nosaukumus gan vëstures avotos, gan mūsdienu izlokšṇu vākumos, Kazimiers Župerka (Šauli) referēja par latviešu un lietuviešu valodas salīdzināmo stilistiku, Andrejs Bankavs -- par arhaisko leksiku un leksikogrāfiju, bet Jānis Valdmanis piedāvāja jaunu literārās valodas lietojuma veidu, variantu, "reg̉istru" klasifikācijas shēmu. Dažiem autoriem klāt neesot, konferencē tika nolasīti vinnu referāti vai to tēzes Dainas Nītinas (Rīga/Sombatheja) pārdomas par vārdu izvēles pragmatiku, kã arī Lembita Vabas (Tallina/Tampere) pētījums par latviešu un Roṇu salas zviedru kontaktiem.

Tâlāk konferences darbs noritēja sekciju sēdēs:

I. Fonētika, fonologija un inorfologija

II. Dialektālă/subdialektālā leksika un leksikogrāfija

III. Sintakse, valodas kultūra un terminologija

IV Literārā leksika un leksikogräfija

Visai aizrautīgi par savu pētījumu objektu diskutēja fonētikas speciālisti. Daces Markus referāts bija veltīts zilbei baltu valodās no teorijas un prakses viedokla, Juris Grigorjevs pievērsās latviešu valodas patskaṇu akustisko ideālformu noteikšanai un aprakstam, Maija Poiša patskaṇu diftongizācijas īpatnībām Vidzemes sēliskajās izloksnēs, Maija Brēde sonanta $/ 1 /$ variantiem latviešu valodā, Genovaite Kačuškiene (Šauli) divskaņu [a.u] un [au.] akustiskajām īpatnībām Zieme|panevēžas izloksnē. Danute Bulzgiene (Šauli) iztirzāja atsevišşas ang!̣ valodas pareizrakstības problēmas, Anna Vulāne raksturoja kādu vārddarināšanas problēmu latviešu valodā - divpakāpju derivātus, savukārt Andra Kalnača ieskicēja verba darāmās un ciešanās kārtas sinonīmijas problemātiku. 


\section{Daudz interesantu ziṇojumu tika nolasīts} dialektālās/subdialektālās leksikas un leksikogrāfijas sekcijā. Elga Kagaine referēja par dažiem mazāk aplūkotiem Baltijas somu valodu aizguvumiem Zieme|rietumvidzemes izloksnēs, Ineta Kurzemniece - par aizguvumiem no Baltijas somu valodām žogu nosaukumos, Brigita Bušmane par nokrejota piena nosaukumu semantiku un dinamiku latviešu izloksnēs, Inese Ėdelmane - par leksiskajām asociācijām latviešu valodas augu nosaukumos. "Latviešu izlokšṇu vārdnīcas" izveides problemātikai bija veltīti \ınanta Šmideberga leksikogrāfiski vērojumi izlokšṇu priedēk|vārdos, kā arī Agra Timuškas leksikogrāfiskas pārdomas par dialektālās frazeologijas variabilitāti, savukārt Vineta Ernstsone informēja par "sarunvalodas" leksikas normatīvo un stilistisko vērtējumu latviešu vārdnīcās un lingvistiskāa praksē, bet Laimute Balode (Rīga/Helsinki) sniedza pārskatu par Latvijas vietvārdiem (konkrēti - oikonīmiem) gadsimtu gaitā.

Pēc krietnām vakariṇām Rīgas Latviešu biedrības Līgo zālē konferences darbs turpinājās 24. februārī divu sekciju paralēlās sēdēs. Sintakses, valodas kultūras un terminoloǵijas sekcijā Maigone Beitina (Liepāja) klausītājus iepazı̄stināja ar teikumu sinonīmiju G.Mancela, E.Glika, A.Bīlenšteina tulkotajās Bībeles nodaḷās, Daiga Baltaiskalna ar konsituativajiem saistījumiem J.N.Ramaṇa "Krusta skolas grāınatā", Ilze Lokmane - ar sintaktisko sinkrētismu teikumā un tekstā. Lielu interesi izraisīja Giedres Čepaitienes (Šauli) referāts par valodas etiḳetes situatīvo un poētisko funkciju, Māra Baltina pētījums "Ar negāciju veidoto slimību apzīmējumu jēdzieniskā struktūra un atveide latviešu valodā", Ivetas Pūteles ziṇojums par dažām problēmām profesiju nosaukumu lietošanas praksē un Regīnas Kvašìtes pārskats par lietišķajiem terminiem dažādos leksikogrāfijas avotos.

Tikmēr literārās leksikas un leksikogrāfijas sekcijā Andrejs Veisbergs informēja par viltus draugiem latviešu valodā, problēmām un atspoguḷojumu vārdnīcā, Jozs Korsaks (Šauli) par aktīvās vārdnīcas lingvostatistiskajām iezīmēm, Laimdota 
Oldere - par adjektīvu labs un laums semantiskajiem laukiem un to attieksmēm, Ilga Migla - par frazeologisinu okazionālajiem pārveidojumiem R.Ezeras darbos. Augstā teorētiskā līmenī bija izstrādāts Olgas Ozolinas referāts par dažiem sistēmas un normas mijjiedarbības attīstības aspektiem, savukārt Guntas Ločmeles ziṇojums par latviešu reklāmas valodas attīstības tendencēm (proti - informācijas kompresiju) īpaši piesaistīja ar praktisku ievirzi un uzskatāmību.

Otrajā plenārsēdē pārdomās par filozofijas terminologiiju resp. dažu M.Heidegera jëdzienu interpretāciju un tulkojumu dalījās Zaiga lkere (Daugavpils), minoritāšu lingvistiskās tiesības Latvijā raksturoja Vineta Porina, savukārt leva Zuicena iepazīstināja ar nule publicēto grāmatu "Latviešu valodas prasmes līmenis" kā latviešu valodas aprakstu funkcionālajā aspektā. Sarmīte Lagzdina aplūkoja mūsdienu principu izmantošanas iespējas latviešu valodas vārdšḳiru klasifikācijā, Anna Stafecka - verbus ar nozìmi 'rakt' un 'apbedīt' latviešu valodas izloksnēs, bet konferences darba programmu noslēdza Jānis Rozenbergs ar referātu "Jānis Endzelīns laika ritumā", secinot: "Mēs atrodamies noteiktā laikā ar savām valodas un valodniecības attīstības savdabībām un tendencēmn un, mācoties no Endzelīna darbīguma, nosvērtības un sīkstuma, pamazām, bet neatlaidīgi savu vagu sekmīgi dzenam tālāk." Vēl par sekcijās nolasītajiem referātiem zị̣oja sekciju vadītāji, kā arī izskanēja vēlējums vēl kuplākā skaitā tikties nākamgad.

Statistiskā aspektā jāsecina, ka 1998. gada konference pulcināja vēl nebijušu dalībnieku skaitu tajā izskanēja 44 valodnieku referāti, arī tēžu krājums "Valoda un tās elementi" jau sasniedzis solīda akadēmiska izdevuma līmeni gan iespieduma kvalitātes, gan satura ziṇā (apjoms 126 Ipp. ieklautas 48 referātu tēzes). Atliek vien̄igi vēlēt tikpat veiksmīgi, kaut lēnām, toties neatlaidīgi dzît tālāk J.Endzelīna tradīcijas vagu valodniecības laukā arī nākamajos gados. Lai labi sokas!

Agris Timuška 


\section{ARTŪRA OZOLA KONFERENCE \\ "VALODAS VẼSTURE UN DIALEKTOLOGIJA" 1998. GADA 18. MARTĀ}

Artūra Ozola konference, ko tradicionāli ik gadus organizē LU Baltu valodu katedra, šoreiz bija veltīta diahroniskās valodniecības problēmām. Konferencē piedalījās kupls skaits zinātnieku un interesentu no dažādām Latvijas augstākajām mācību iestādēm un zinātniskās pētniecības centriem. Programmā bija ietverti pāri par 20 referātu, kuru tematiskais loks bija visai daudzveidīgs un aptvēra vairākas diahroniskās lingvistikas nozares - dialektoloǵiju, toponīmiku, rakstu valodas un dialektālo izdevumu vēsturi un ar tiem saistītās problēmas dažādos aspektos. Konferences darbs ritēja divās plenārsēdēs un paralēli vairākās sekcijās.

Pirmajā plenārsēdē (vadītāja Dz.Paegle) tika nolasīti trīs referāti. A . Breidaks savā referātā "Diahroniskās fonologijias loma latviešu valodas vēsturiskās fonētikas problēmu izpētē" aplūkoja latga|u cilts valodas patskaṇu fonemātiskās apakšsistēmas attīstību un no tās izrietošās konsekvences par latgalisko izlokšṇu fonētikas principiāliem jautājumiem. P. Vanags referēja par debitīva formu lietojumu 16.gs.-17.gs. sākuma latviešu rakstu valodā, bet $\underline{\text { B }}$.Laumane savā referātā "Ventinuu valodas identitātes meklējumi" rosināja pievērst uzmanību vairāku dzilo tāmnieku (ventiṇu) izlokšnu areālam, kura aprises dalēji sakrīt gan ar Ventspils apriņḳi, gan ar seno kuršu novadu Ventāva. Diemžēl mūsdienu izlokšņu leksikā konstatētās lokālās īpatnības pagaidām nespēj atrisināt Indriḳa hronikā minēto vendu jeb ventịnu etnisko piederību.

Sekcijā, kas bija veltīta izlokšṇu leksikai (vadītājas L.Leikuma, Dz.Paegle) tika risināti vairāki dialektālās leksikologijas un leksikogrāfijas jautājumi. A. Timuška referātā "Tradicionālais un novatoriskais topošajā "Latviešu izlokšṇu vârdnīcā"”" aplīkoja šajā vārdnīcā izvēlētos uzbūves principus 
salīdzinājumā ar līdzšinējām latviešu dialektālās leksikogrāfijas tradīijāām (ME, EH, ĒIV, KIV) un pievērsās tiem aspektiem dialektālo leksēmu leksikogrāfiskajā raksturojumā, kuriem šajā vārdnīcā būtu nepieciešamas inovācijas pārcelto formu atveides kritērijiem, fonētisko un morfologisko formu detalizācijas pakāpei (sīkāku šo īpatnību aprakstu katrai izlokšṇu grupai paredzot sniegt vārdnīcas ievadā), frazeolog̀iska rakstura vārdu savienojumiem u.c. Pēc referenta domām, īpaša uzmanība pievēršama norāžu sistēmas izstrādei topošajā vārdnīcā, lai varētu sniegt priekšstatu par vārda vietu kopējā izlokšṇu sistēmā un mijattiecībām ar citām valodas vienỉbām.

Atsevišķi baltu un somugru valodu kontaktu izpausmju aspekti, balstoties uz Zieme|rietumvidzemes izlokšņu materiāliem, tika skarti E. Kagaines referātā "Ziemelvidzemes izlokšṇu leksiskie somugrismi (starpvalodas ietekmes)", konkrēti pievēršoties tãm germāniskās cilmes leksēmām, kas latviešu valodas izloksnēs ieviesušăs ar igauṇu valodas starpniecību (lekteris, meska, toterēt, napītis).

B. Bušmane savã ziṇojumā "Verbi ar nozīmi 'gatavot (sviestu)' latviešu valodā" semantiskã un areālā skatījumā aplūkoja latviešu valodas izloksnēs ar šo nozīmi reǵistrētos verbus, kas pãrsvarā ir mantoti vārdi un kam raksturīgs plašs semantisks sazarojuıns (piemēram, berzt, darīt, griezt, kult, sist). I. Kurzemniece turpināja risināt aizsākto tēmu par žogu nosaukumiem latviešu valodas izloksnēs, šajā konferencē pievēršoties žogu nosaukumu darināšanai.

Atsevišķā sekcijā tika risināti arī latviešu rakstu valodas vēstures jautājumi (vadītājas A.Kalnača, D.Nītiņa). Par infinitīvteikumiem latviešu rakstu valodas sākotnē informēja $\underline{\text { M}}$ Beitina. K.Pokrotniece referātā "Palīgteikumi ar ja: vēsture un problēmas" aplūkoja palīgteikumus, ko ievada saiklis $j a$, un izsekoja palīgteikumu noz̄̄nju veidošanās vēsturei latviešu rakstu valodā. Kaut gan saiklis ja parasti tiek saukts par nosacījuma saikli, izrādās, ka rakstos (16.gs.) vispirms parādījušies teikumi, kas izsaka pie|āvuma nozīmi. Mūsdienās saiklis ja sastopams nosacījuma, pie|āvuma, teikuma priekšmeta, 
papildinātāja un apzīmētāja palīgteikumos. Referente nedaudz skāra arī jaunāko saikla ja izmantošanas veidu - teikumus ar saik|u pāri ja tad, taču laika trūkuma dē| šo problēmu neizvērsa. 1.Jermacāne referātā "Substantīvu salikteṇi G.Manteifela kalendāros" aplūkoja šajos latgaliešu rakstu valodas izdevumos, kas iznāca pagājušā gadsimta vidū, sastopamos substantīvus. Problēmu rada G.Manteifela nekonsekventā rakstība, tảs rezultātā ne katrreiz salikteṇi precīzi nošķirami no vienkārši kopā uzrakstītiem substantīviem.

1.Jansone ieskicēja K.Fīrekera devumu latviešu leksikogrāfijāa 17.gs. vid̄̄, atzīmējot viṇa vārdñicas (divu variantu) lielisko leksikogrāfisko apdari, t.i., šķirkla struktūras izveidi, ġeogrāfisko un etimolog̣isko norāžu izstrādi, homonīmijas un polisēmijas jautājumu risināšanu, ilustratīvā materiāla iek|aušanu u.tml.

D. Baltaiskalna referātā "Sintaktiski stilistiskie spēcinājumi 18.gs. beigu latviešı rokraksta literatūrā" tuvāk aplūkoja stilistiskos spēcinājumus divu autoru darbos: Kịu|a Jēkaba "Dziesmās" un J.N.Ramaṇa "Krusta skolas grāmatā" Stilistiskie spēcinājumi izteikti ar sintaktiskiem elementiem, galvenokārt ar teikumu un tā locekliem (piem., blīvējumi, atkārtotu vārdu konstrukcijas, tautologijija, pastiprinājuma g̀enitīvs, piederuma ġenitīvs, elidācija, salīdzinājuma konstrukcija, savrupinājums u.tml.).

Vêl šajā sekcijā tika nolasīti vairāki referăti par konkrētiem gramatikas, stilistikas u.c. jautājumiem: $\underline{\text { R.Grīsle }}$ "Vai latviešu valodā ir instrumentālis?", L.Dimante "Adverbu transpozīcija slāvu un baltu valodās" Tà kā visi referenti uz konferenci nebija varējuši ierasties, tad nenolasīts palika programmā paredzētais $\underline{V}$. Rimšas (Kauṇa) referāts "Baltu pseidoslāvismi”

Toponimijas sekcijā (vadītāji P Vanags, L.Leikuma) pirmo referātu nolasīja viešṇa no Šauliem lietuviešu valodniece $\underline{G}$.Kačuškiene par neuzsvērtu $i / u$ un e/o lietojumu Jonišķēles un Pakrojas saistītos tekstos (Nekirčiuotu $i / u$ ir $e / o$ vartojimas Jonišḳèlio ir Pakruojo rišliuose tekstuose). 
A.Stafeckas referāts "Izlokšņu ipatnības Latgales rokraksta literatūrā" bija veltīts ievērojamākajam Latgales rokraksta literatūras pārstāvim Andrivam Jūrdžam (1845-1925), kura atstātais literārais mantojums sniedz vērtīgas zinnas arī par viṇa dzimto Nautrēnu izloksni. Referente konstatējusi, ka rokraksta literatūras valoda ir daudz tuvăka tautas runai nekā pirms drukas aizlieguma iespiesto grāmatu valoda. Interesants ir arī fakts, ka līdz drukas aizliegumam latgaliešu grāmatu autori bija galvenokārt cittautieši, taču drukas aizlieguma laikā rokrakstu literatūru radīja paši latviešu zemnieki, tā nodrošinot latgaliešu rakstības un literatūras procesa nepārtrauktību. L.Leikuma referātā "Izlokšṇu pēdas Latvijas vietu vārdos" pieskārās pašlaik aktuālai tēmai - vietvārdu atveidei un konstatēja, ka liela daja Latvijas vietvārdu ir sastoparna izloksnes formā un nereti glabā valodas vēstures dotumus. Tâpēc jo īpaši aktuāli, pēc referentes domäm, ir netransponēt vietvārdus, jo transponēšana bieži bien noved ne tikai pie k!̣̄îāı, bet arī kurioziem gadijumiem vietu nosaukumu atveidè.

Par Madonas apkārtnes vietvārdiem (balstoties galvenokārt uz J.Endzelīna vietvārdu publikācijām) referēja

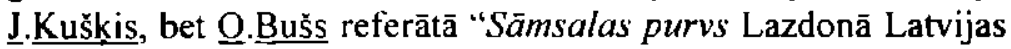
toponīmikas kontekstā" stāstīja par kādu gandrīz jau aizmirstu vietvārdu - Sāmsalas purvs Lazdonā, saistot tā cilmi ar Baltijas jūras somu valodām (sal. somu sammal "sūnas"), kā arī mazliet ieskicējot Latvijas un Somijjas "sūnu" vietvārdu sastatījumu.

Konferences nosléguma sēdè tika nolasīti divi referāti, kuros atspogulota gan konkrētas nozares terminologijas attīstības gaita, gan latviešu valodas mācību literatūras attīstība. $\underline{\text { V.Skujina }}$ savā referātă "No tehuiskās terminoloğijas attîstības vēstures", īsi skarot vissenākajā latviešu aroddarbībā lietotos terminus un vācu mācītăju gatavotajās 17.--19.gadsimta vārdnīcās minētos terminus, galveno uzmanību veltijja tehnisko terminu modeliem, kādi attīstījās, sākot ar latviešu autoru darbības laiku 19.gadsimta vidū un tika tālāk attīstîti 20.gadsimta 20.-30.gadu terminu vārdnīcās (piem., būvniecībā, enerǵētikā). Šie modẹ̣i joprojām noder par jaunu terminu veidošanas bāzi arī mūsdienu 
vajadzỉbām. Dz.Paegle analizēja skolu gramatiku izstrādes principus padomju okupācijas sākumposmā (40-to gadu otrajā pusē). Referente salīdzināja J.Endzelīna un K.Mīlenbaha "Latviešu valodas mācības" 1939.gada izdevumu ar pirmajām pēckara latviešu valodas mācỉbu grāmatām: bezautora 1945. gadā izdoto "Latviešu valodas gramatiku" un M.Alkšña, O.Vilāna 1948.gadā izdoto "Latviešu valodas gramatiku"

Konferences beigās sekciju vadītāji rezumēja paveikto kopumā, pozitīvi vērtējot dažādos pētījumu aspektus un ieskicējot arī tāläko pẹtījumu virzību.

Elga Kagaine

\section{LINGVISTISKO CILVĒKTIESĪBU PROBLEMĀTIKA ZINĀTNE UN POLITIKĀ}

Lingvistiskās cilvēktiesības ir juridiski konkrētas valodas un tās runātāju tiesības lietot šo valodu noteiktās sociolingvistiskās sfērās. Lingvistisko cilvēktiesību koncepts ir 90.gadu auglis, kas radies, sakrustojot valodas tiesību un cilvēktiesību jēdzienus. Tā pamatideja ir saglabāt strauji mirstošās valodas, izlīdzinot atšḳirīgās valodu hierarhijas pakāpēs esošo valodu tiesības, juridiski piešḳirot privilégijas valodām ar mazāku tirgus vērtību, runātāju skaitu, prestižu u.tml. Ideja, protans, atbilst 20. gadsimta beigu vispārcilvēciskajām nostādnēm un ir tikai apsveicama. Tomēr, apzinot veidu, kā lingvistisko (valodas) tiesību jēdziens tiek izmantots Latvijas valodas politikas vērtēšanā, rodas iespaids, ka zinătniski vēl nepietiekami izstrādātais jēdziens lieliski noder arī politiskām manipulācijām. Tầē| ir apsveicama starptautiskās zinātnieku sabiedrības aktivitāte lingvistisko tiesību izpētē.

1997.gada 16.-19.oktobrī Budapeštā notika Ungārijas ZA Lingvistikas institūta un Centrāleiropas universitātes Cilvēktiesību progranmmas organizētā starptautiskā konference par lingvistisko cilvēktiesību jautājumiem. Latviju šajā 
konferencē pārstāvēja Vineta Ernstsone, Vineta Poriṇa un šîs informācijas autore.

Beidzamos gados notikuši vairāki kongresi un konferences par likumdošanu valodas jomā, kur aktīvi pārspriesta arī Latvijas valodas politika (piem. "Likums un valoda" Fribūrā, ASV Antropolog̀iskās asociācijas kongress Atlantā (1994), Eiropas valodas politikas konference Barselonā (1995), 6. starptautiskā minoritāšu valodu konference Gdanskā, 11. Pasaules lietišḳās valodniecības kongress Jiveskvilè (1996), 14. Austrumeiropas studiju asociācijas konference Kembridżă, kongress "Valodu kontakti un konflikti" Briselē (1997). Sociolingvisti, pretēji politiķiem, atzīst, ka lingvistiskās cilvëktiesības un valodu tiesības ir loti sarežgīita parādība, un vēl nav izdevies atrisināt teorētiskās pamatpretrunas, kas apgrūtina šo jēdzienu ieviešanu konkrētu valstu juridiskajā praksē. Konceptuāläs neskaidrības tomēr nav bijušas par šḳērsli vairāku starptautiski saistošu dokumentu pieñemšanai (piem., Eiropas Reǵionālo vai minoritāšu valodu harta (1992), Bāzes konvencija nacionālo minoritāsu aizsardzībai (1994), Universālā lingvistisko tiesību deklarācija (1996), Kopenhägenas (1990), Hăgas (1996), Oslo (1998) rekomendācijas u. c.). Konfrontācija starp zinātnieku un politiķu pieeju valodas tiesībām īpaši izteikta ir Centrāleiropas un Austrumeiropas valstīs notiekošo valodu hierarhijas maiṇas procesu vêrtējumā. Tādēl Budapeštas konferences uzmanības centrā bija tieši šis reǵions. Referāti bija iedalāmi divās grupās: teorētisko problēmu analīze un pārskati par konkrētu valstu valodas politiku saistībā ar starptautiski akceptētām normām.

Konferencē piedalijjās daudzi no ne pārāk plašās valodas politikas speciālistu elites. Fransuā Grens (Grin) (Šveice) analizēja ekonomisko faktoru ietekmi uz valodu konkurenci, stiprinot mūsu pārliecību par stingru normatīo aktu nepieciešamību zemākas tirgus vērtības valodu aizsardzībā. Anželīna Martela (Kanāda) pievērsăs indivīda, valodas kolektīva un valsts lomai valodas noturībā, Roberts Filipsons (Phillipson) (Dānija) skaidroja ang!̣ valodas ekspansijas cêloṇus un sekas, 
Tuve Skutnaba-Kangasa (Dānija) atzina, ka "brīvā tirgus" attiecỉbas valodu lietojumā ir vislielākie draudi mazajām valodām, it īpaši, ja konkurentvaloda pieder pie t.s. lielajām galētājvalodām (big killer languages). Patriks Tornberijs (Thornberry) (Lielbritānija) saistîja indivīda un valodas kolektīva lingvistiskās tiesības. Fernands de Varenness (Austrālija) uzskaitīja juridiskos aktus minoritāšu aizsardzībai, demonstrējot, mūsuprāt, visai formālu pieeju minoritātes jēdzienam. Uldis Ozolinšs (Austrālija) izvirzīja hipotēzi, ka stingra lingvistiskā likumdošana Baltijas valstīs drīzāk mazina starpnacionālos konfliktus, bet nevis tos provocē, kā vēlas iestāstīt pavirši Latvijas valodas situācijas analizētāji. Pārstāvji no Ungārijas, ASV, Turcijas, Vācijas, Krievijas, Ukrainas, Albānijas, Slovēnijas, Belg̀ijas vairāk pievērsās konkrētiem valodas politikas un minoritāšu valodu tiesību aspektiem, atklājot vairākas interesantas paralēles ar Latviju.

Latvijas pārstāvju referātos tika analizēta aktuāāā situācija valstī saistībả ar ilgstošajām debatēm par Valsts valodas likumprojektu (1995). Tā kā zinātniekiem atšķiríbā no politiḳiem ir ne tikai tiesības, bet pat pienākums izteikt savu viedokli pat tad, ja tas ir pretrunā ar varas nesēju vairākuma uzskatiem, norādijjām uz, mūsuprāt, diskutējamiem un zinātniski nekorektiem apgalvojumiem tādas tabuêtas organizācijas kā EDSO atzinumos par Latvijas valodas politikas pamatvirzieniem (Opinion on the Compatibility of the Draft Latvian State Language Law with International Standards. Office of the OSCE, 22 September 1997) (tas pats būtu attiecināms arī uz EDSO 1998.gada 23.marta komentāriem un Eiropas Padomes ekspertu grupas ziṇojumu 1998.g. 30.martā). Atšķirïbā no pašreizējāım ES dalībvalstīm Latvijas Republikas lingvistiskā likumdošana paredz valsts struktūru mērḳtiecīgu darbību, lai pastāvošajos politiskajos un lingvodemogrāfiskajos apstāk|os mainītu hierarhiskās attiecības starp valsts valodu latviešu valodu un vienu no minoritāšu valodām krievu valodu, vienlaikus garantējot iespējas lietot minoritāšu valodas noteiktās sociolingvistiskās funkcijās. 
Valodu lietojumu jeb valodu sociolingvistisko funkciju sadalījumu Eiropas Savienības dalībvalstīs joprojām nosaka galvenokārt atsevišḳu dalībvalstu likumi. Pēdējos gados dalībvalstu, kā arī ES kandidātvalstu valodas politiku aizvien vairāk ietekmē starptautiskās organizācijas (piem. Eiropas Padome, EDSO, Baltijas jūras valstu padome), kā arī starpnacionālajā līmeñ̄ pieṇemtie dokumenti cilvēktiesību un minoritāšu tiesību jomā. Tā kã etnodemogrāfiskã un valodas situācija katrā valstī ir atšķirīga, starptautiski saistošajos normatīvajos aktos iespējams iestrādāt tikai vispārīgas vadlīnijas etniskajai un valodas politikai; daudzu normu realizācijas lietderību jauts izvērtēt pašāın parakstītājvalstīm. Minoritāšu tiesību un lingvistisko cilvēktiesību koncepts pašlaik vēl atrodas attīstības stadijā un ir asu zinātnisku un politisku diskusiju objekts. Lìdz ar to pastāv samērā plašas iespējas atšķirīgiem viedokliem par starptautisko dokumentu normām un pat voluntāram atsevišķu pantu traktējumam, ko pierāda arī debates par Valsts valodas likumprojektu. Mūsuprāt, Latvija pietiekamā mērā nav îstenojusi savas likumīgās tiesības izmantot starptautiski saistošajos dokumentos pie|autos ierobežojumus un atrunas konkrētu pantu traktējumā, līdz ar to $k$ |ūstot par praktiski vienigo Eiropas valsti, kuras valodu likumā var tikt ietvertas maksimālās iespējas minoritāšu valodu (respektīvi krievu valodas) lietojumam. Politiski šādi varbūt tiks sasniegti īslaicīgi ārpolitiski un iekšpolitiski mērḳi. Bet nedrīkstētu būt nekādu ilūziju par latviešu valodas prasmes un lietojuma (tas nav viens un tas pats!) progresu. Minoritātes (turklāt tikai juridiskas, ne faktiskas minoritătes) valodas pašpietiekamỉbas apstāklos valsts valodas lietošanu var stimulēt tikai ekonomiskā (kas nav reāli) vai juridiskā celā. Valodas politikas zinātne, apkopojot daudzu valstu pieredzi gadu desınitos un simtos, rāda, ka iẓ̣ēmumu no š̄ likuma nav.

Vissarežgìitākā problēma valodas tiesību un lingvistisko cilvēktiesību teorijā saistās ar šo jēdzienu universalitātes iespējamību vai neiespējamību. Izcili valodas politikas un cilvēktiesību speciālisti atrodami abu viedokḷu aizstāvju vidū. 
Vairums ASV zinātnieku, piemēram, izcilā valodas speciāliste Kristīna Brata-Paulstone, principā noraida iespējamību noteikt vienotus valodas tiesību standartus neatkarīgi no valodas situācijas valstī. Analizējot Latvijas valodas politiku, piemēram, vêrtējums var büt atkarīgs no tā, vai tiek ṇemti vērā ġeopolitiskie, etnodemogrāfiskie un psihologiskie apstāk|i valstī. Starptautiskie dokumenti valodas tiesībās izstrādāti, pamatojoties uz Rietumeiropas sabiedribas valodisko modeli: 1) minoritātes valodas runātāji ir jūtamā mazākumā, 2) tie ir vai vismaz cenšas būt bilingvāli dzimtajā valodā un valsts valodā, 3) valsts valodas runātāji var isstenot lingvistiskās cilvēktiesîbas pilnā apjomā. No šiem pamatnosacījumiem Latvijā nepastāv neviens, bet šo faktu ārvalstu eksperti konsekventi ignorē. Tâdē! valsts valodas un minoritāšu valodu attiecību konteksta ignorēšana Latvịias apstākjos var radīt pretēju efektu lingvistisko cilvēktiesību pamatidejai - aizsargāt noteiktas valodas runātājus pret lingvistisko asimilāciju. Līdz ar to nākas secināt, ka pastāv dzi|a plaisa starp Latvijas valodas politikas sociolingvistisko un politisko aspektu. Latviešu valodas runātāju tiesību nodrošināšanai pašreizējos valodu konkurences apstāklos nepieciešams daudz stiprāks valstiskās aizsardzības mehānisms, nekā visai ultimatīvā formā tiek ieteikts ārvalstu ekspertu atzinumos.

Nevar apgalvot, ka Budapeštas konferencē Latvijas pārstāvju viedoklis būtu guvis vienprātīgu atbalstu, kaut, nenoliedzami, atbalstîtāju bija vairāk nekā oponentu. Baltijas valstu valodas situācija zināmā mērā apstrīd starptautisko standartu universāluınu un sarežğì formālo kritēriju (majoritātes valoda minoritātes valoda) izmantošanu. Konferences noslēguma secinājumi bija tradicionāli lingvistisko cilvēktiesîbu jomā vēl loti daudz pētāma, un šĩ tikšanās bijusi mazs, bet nozīmīgs solis problēmas padziḷinātā izpētē.

Var piebilst, ka plašāki raksti, kas sagatavoti uz konferences referātu pamata, publicēti grāmatā "Approaching Linguistic Human Rights" Ed. by M.Kontra, T.Skutnabb-Kangas, R.Pliillipson. Budapest: OSI, 1998. 


\section{8.gada 26.februārī Maskavas A.Saharova} muzejcentrs rīkoja apa|o galdu "Lingvistiskās cilvēktiesỉbas" Apa|ajā galdā piedalījās ap trīsdesmit dažādu sabiedrisko organizāciju pārstāvju no Krievijas Federācijas, Maskavas valodnieki (M.Djačkovs, V.Alpatovs u.c.), kā arī daudzi interesenti. Ārzemes pārstāvēja Ina Druviete.

Beidzamajos gados ir apsīkuši kontakti ar bijušās Padomju Savienỉbas republiku kolēgiem, un ir visai grūti iegūt informāciju par to, kas valodas politikas jomā notiek NVS valstīs. Deviñdesmito gadu sākumā gandrīz visās republikās tika pieñemti 'Valodı likumi, kas attiecīgās teritorijas pamatiedzīvotāju valodai noteica valsts (oficiālās) valodas statusu, tiesa, daudzos gadijumos blakus krievu valodai. Paplašinājās preses un literatūras izdošana šajās valodās, tika paredzēta to mācišana un lietošana visu līmeņu izglītíbas sistēmā, kā arī ieviesti citi nepieciešamie juridiskie nosacījumi, lai kompensētu valodu funkciju zudumu rusifikācijas laikā. Par situāciju valodas jomā stāstīja komiešu, udmurtu, uzbeku, ukrainıu u.c. pārstāvji. Pašlaik varaın vērot visai pamācošu ainu valodu hierarhijas maiña gandrīz visās republikās ir praktiski apstājusies. Iemesli tam ir vairāki - ekonomiskie faktori, zems lingvistiskās pašapziṇas līmenis, minoritātes resp. krievu valodas runātāju lingvistiskā pašpietiekamība, asimetriskās divvalodības tradīcijas u.c. Tomēr svarīgi ir arī ideologiskie faktori, kas šajā sanāksınē atklājās visai neslēpti. Nav nekāds jaunums, ka cilvēktiesību jēdziens nereti tie izmantots demagogiski, tomēr tik klajā formā šādas manipulācijas nenākas redzēt bieži. A.Saharova vārds un cilvēktiesību lozungs, izrādās, var tikt izmantots, lai aizstāvētu krievu tiesības palikt vienvalodīgiem "nacionālajās nomalēs" Piemēram, prasība mācīt udmurtu valodu Udmurtijas skolās ar krievu mācībvalodu tika kvalificēta kā lingvistisko cilvēktiesību pārkāpums. Pret šādu nostāju protestēja tikai daži sanāksınes dalībnieki, tai skaitā Latvijā pazīstamais Marks Djačkovs. 
Bez loti noderīgās faktologiskās informācijas nozīmīga škita diskusija ar M.Djačkovu par termina valodas kolektīvs (language community) traktējumu. Likās vismaz nepierasts M.Djačkova viedoklis, $\mathrm{ka}$, piemēram, latviešu valodas kolektīvam būtu pieskaitāmi arī Latvijas cittautieši, kas apguvuši latviešu valodu. Tradicionāli valodas kolektīvi tomēr tiek izdalīti pēc ikdienā, gimenē lietojamās valodas kritērija, un Latvijā līdz šim runāts par diviem galvenajiem valodas kolektīviem latviešu un krievu, kā arī par nelieliem mazo minoritâšu valodas kolektīviem. Tomēr. ja atbalstām viedokli, ka ikviens, kas apguvis un lieto latviešu valodu, stiprina latviešu valodas pozīcijas, nav piln̄īā noraidāma arī šāda termina interpretācija.

Konferencēs noritēja diskusijas arī par citiem terminiem

pat par pašu pamatterminu lingvistiskās cilvēktiesibas. "Universālajā lingvistisko tiesību deklarācijā" (1996) par pamatprincipu izmantots pieṇèmums, ka lingvistiskajām tiesībăm vienlaikus ir gan individuāls, gan kolektīvs raksturs, un viens un tas pats termins lingvistiskās (cilvēk)tiesības (linguistic (human) rights) tiek izmantots abos gadījumos. Mērķtiecīgāk tomēr škiet šo terminu attiecināt tikai uz indivīda tiesībām. Indivīda lingvistisko cilvēktiesību realizācija parasti ir tieši saistīta ar viña runātās valodas tiesībām attiecīgajā teritoriālajā veidojumā. Kolektīvo tiesību sfērā valstī lietoto valodu juridiskajā regulēšanā saistībā ar etnosu politiskajām un sociālajām tiesībām būtu vēlams lietot terminu valodas tiesības (language rights). Tomēr vēl joprojām nav starptautiski akceptētas šo terminu definīcijas, un plašajā zinātniskajā literatūrā trūkst konsekvences to traktējumā. Šai nenoteiktībai ir tiešas politiskas sekas, ko mēs Latvijā pašlaik labi izjūtam.

Ina Druviete

\section{BALTISTI TIEKAS NEVAS KRASTOS}

No šā gada 10. līdz 12. martam senajā, bet joprojām aristokrātiskajā Pētera I pilsētā, Sanktpēterburgas universitātē 
pulcējās baltisti no dažādām Eiropas valstīm, lai parunātu, padiskutētu konferencē, kas nosaukta "Baltu valodas - apajais galds" Šo pirmreizējo konferenci iecerēja un to lieliski noorganizēja jauns un talantīgs Sanktpēterburgas universitātes doktorands Aleksejs Andronovs, kas kādu laiku ir stažejjies gan Vi|ṇā, gan Rīgā un brīvi apguvis abas baltu valodas. Viṇa nodorns - saaicināt jaunos baltistus un pierādīt, ka arī senajā Sanktpēterburgas universitātē (dibināta 1724. gadā) ir dzīvs baltistikas gars, - piepild̄jjās pilnā mērā.

Svinīgajā konferences atklāšanā piedalījās un labus novēlējuma vārdus teica gan Filologijas fakultātes dekāns, gan vietējā profesūra, gan Lietuvas un Latvijas konsulātu darbinieki. Visi bija vienisprātis, ka, tieši pateicoties Alekseja Andronova entuziasmam un energijai, tik daudz jaunu valodnieku - baltistu tiekas Nevas krastos.

Trijās konferences darba dienās tika nolasīti joti plaša diapazona referāti.

Par valodas vēsturi un seno tekstu valodu runāja Everita Milčonoka (Rīga) ("Prievārdu lietošana G.Manceja "Lettische Postill" fragmenta tekstā"), Ričards Petkevičs (Ričardas Petkevičius) (Vịnna-Rīga) ("Relig̣ijas terminu gars/dvesia leksiskie varianti pirınajos Jaunās Derības tulkojumos lietuviešu un latviešu valodā"). Ar latgaliešu rakstu valodas vēsturi klātesošos iepazīstināja Lidija Leikuma (Rīga).

Onomastikai bija veltîti četri referāti. Jurijs Otkupščikovs (Sanktpēterburga) iedziḷinājās baltu un Balkānu onomastikā, meklēdams kopīgās baltu-balkāniešu izoglosas. Par baltu onomastikas mūsdienu stāvokli un perspektīvām runāja Laimute Balode (Riga-Helsinki). Latgales vietvārdu rakstības aktuālas problēmas izcēla Lolita Belska (Rīga). Ojärs Bušs (Rīga) sniedza izsıne|ošu viena Latvijas vietvārda analīzi (Sämalas purvs <s. ig. sammal, līb. sămal 'sūnas').

Etimologijai veltîtus referātus nolasīja Vanda Kazanskiene (Sanktpēterburga) (par liet. alìs, latv. alus < liet. verba alèti 'lēni tecêt', saistot ar seno alus gatavošanas procesu) un $\underline{\text { Jurijs }} \underline{\text { Hramovs }}$ (Rīga), kurš analizēja baltu kinologisko 
leksiku no etimologiskā viedokḷa (par leksēmām suns, kurts, pierādot, ka arī kurts ir nevis aizgūts vārds, kā tika uzsvērts lìdz šim, bet gan mantots baltu vārds). Dzilu, uz plaša materiāla balstītu referātu nolasīja igauṇu valodnieks Lembits Vaba (Tallina-Tampere), kas izcēla vairākas jaunas igauṇu baltismu hipotēzes (ig. loja, palu, tiir u. c.).

Dialektologijas jautājumiem savus ziṇojumus veltīja lietuviešu jaunie valodnieki Asta Leskauskaite (Vi|ṇa) (runāja par depalatalizāciju lietuviešu dienvidrietumu izloksnēs) un $\underline{E d m u n d s}$ Trumpa (Vilna) (referēja par ${ }^{*} t j,{ }^{*} d j$ refleksiem un dzühavima iespējamo cilmi).

Par mūsdienu lietuviešu akcentologiijas parādībām stāstĩja Bonifācs Stundža (Bonifacas Stundžia) (Vilṇa).

Latviešu kā svešvalodas apgūšanas grūtỉbas pamudinājušas pievērsties un izskatīt tradicionālo verbu konjugāciju iedalị̣umu. Šiem sarežğîtajiem morfoloǵijas jautājumiem bija veltīti divi referāti - Dainas Nitinas (Rīga) un Alekseja Andronova (Sanktpèterburga) pārdomas un secinājumi. Par pagātnes aktīvā divdabja lietojumu baltu un austrumslāvu valodā stāstīja Valentīns. Trubinskis (Sanktpēterburga). Ar bērnu valodas pētījumiem morfolog̀iskā aspektā ir aizrāvies un klausitājus prata aizraut Pavels Vojciks (Poweł Wójcik) (Varšava).

Sintakses problemātiskiem jautājumiem bija pievērsušies vairāki referenti. Aksels Holvuts (Axel Holvoet) (Varšava) runāja par latviešu modālā vārda lai funkcijām un gramatisko vietu. Inga Klèvere (Rīga-Sombatheja) savam referātam bija izvēēejusies intriğējošu nosaukumu: "Latviešu verba saliktie laiki: izšķērdība vai nepieciešamība?" (uz šo jautājumu atbildēdama - nepieciešamība). Olita Rause (Rīga) runāja par teikuma saliktu locekḷ tipolog̣iju. Artūrs Jüdžentis (Viḷna) analizēja salikta teikuma struktūru lietuviešu valodas gramatikās. Ar latviešu valodas sintaktisku konstrukciju automatizētas apstrādes iespējām iepazīstināja Inguna Greitāne (Rīga). 
Jaunais baltists no Vācijas Bjorns Vimers (Björn Wiemer) (Konstanca) centãs iedzilināties sarežgītos polisēmijas implicitātes jautājumos, paveroties no tipologijas viedok|a. Tāpat tipoloğiski aspektuālo nozimi analizēja valodniece no Ungārijas Aranka Lachazi (Budapešta).

Divu vārdu semantiskajām attieksmēm radniecīgâs valodãs (liet. jautrùs un latv. jautrs) bija veltīts Antas Buhärinas ziṇojums.

Sāpīgu izzūdošās somugru tautas - ižoriešu - valodas likteni apcerēja Ilia Nikolajevs (Sanktpēterburga).

Latyiešu valodnieces Veltas Rūḳes-Dravinas jubilejai un vinas paveiktā darba vērtējumam bija veltīts Leonarda Gercenberga (Sanktpēterburga) stāstījums.

Divi referāti skāra nevis valodniecības, bet gan literatūras sakaru jautājumus: Fatima Jelojeva informēja par lietuviešu rakstnieka Toma Venclovas tulkojuma vēsturi, bet F.Bahčinjans no Arınēnijas (Alaverdi) stāstīja par Armēnijas ietekmi uz E.Mieželaiša dailradi.

Tomēr galvenā atziṇa, kas pavadija mājupce|ā pēc šīs konferences, bija tā, ka Sanktpēterburgas universitātē būs vēl viens centrs, kur tiks mācītas un popularizētas senās baltu valodas. Un vēl - tas, ka, neskatoties uz grūtiem laikiem zinātnē, mums ir laba, stipra. gudra, azartiska jaunatne, kas nelaus baltu valodniecībai aiziet zudumā.

Laimute Balode

\section{IZLOKSNES: PĒTNIECĪBA UN PERSPEKTĪVA}

Noskaidrot izlokšṇu pētniecības pašreizējo stāvokli un turpmākos uzdevuınus uz šādu mērḳi tiecies Šaulu universitātes Humanitārās fakultātes Dialektologijas centrs, rikojot Aldonas Jonaitītes septinndesmitgadei veltītu seminäru "Tarmès: tyrimas ir perspektyva" š.g. 24. aprīìi. Par to, vai mērķi izdevās sasniegt, varēja pārliecināties arī latviešu dialektologu delegācija, kas bija laipni aicināta piedalīties seminārā $D r$. 
habil. philol. B. Bušmane, Dr. philol. A. Stafecka un šo rindu autors.

Seınināra atklāšanā itin sirsnīgi un neliekuloti, bez formālām apsveikuma runān tika godināts A. Jonaitītes ieguldījums lietuviešu dialektolog̉ijas attīstībā; jubilārei arī turpmāk ražīgi darboties izvēlētajā valodniecības apakšnozarē vēlēja kolēgei no Šau|u universitātes, Lietuviešu valodas institūta Vi|ṇā un Latviešu valodas institūta.

Darba kārtība bija samēră saspringta - tajā bija paredzēti 20 referāti, no kuriem 17 arī tika nolasīti. Vispārīgu ieskatu lietuviešu valodas izlokšṇu izpētes vēsturē un soodienā sniedza Kazis Morkūns (Vị̣na), savukārt vairums pārējo referentu bija pievērsušies kādas konkrētas izloksnes vai atsevišķas valodiskas parādības izpētei. Tā Skaistgires apkārtnes vietvārdu izpētes problēmām bija veltīts Nerijas Bartkutes (Šauli) referāts, Česis Grenda (Šauli) atspēkoja vietvārda Lykśelis līdzšinējo etimolog̀jju, par kādas zieme|rietumu aukštaišu izlokšṇu fonētiskās ippatnības - līdzskañu $s, z$ un $\check{s}, \check{z}, c, \check{c}$ un $d z$, $d \check{z}$ jaukuma - saglabāšanos Žagares izloksnē atraktīvi referēja Jozs Pabrēža (Šauli), Asta Kazlauskiene (Kauṇa) informēja par morfèmas blakusuzsvariem dienvidrietumu aukštaišu izloksnēs, bet Da|a Kise|ūnaite (Klaipēda) - par Kuršu kāpu kursenieku izloksnes izpētes aspektiem.

Dạa referātu skāra izlokšṇu leksikas izpētes un leksikogrăfiskās atveides problemātiku: Vilija Lazauskaite (Vilṇa) informejja par apvidvärdu un to nozīmju atveides specifiku "Mūsdienu lietuviešu valodas vārdnīcas" trešajā laidienā, G̣iedre Čepaitiene (Šauli) analizēja izlokšņu leksikas škiruma principus. Ar izlokšn̨u tekstu fragınentiem Latviešu valodas dialektu atlantā iepazīstināja Brigita Bušmane (Rīga), Kazimiera Garšvas (Vi|̣̣a) referāts bija veltīts latvismiem, pārējiem aizguvumiem un kopigajai leksikai Zieme|lietuvas izloksnēs, bet Agris Timuška (Rīga) stāstīja par Latviešu izlokšņu vārdnīcas izveidi latviešu dialektālās leksikogrāfijas tradīciju kontekstā. 
Vītauts Vitkausks (Vilṇa) teorêtiskā līmenī izvirzīja ideju par žemaišu un zieme|aukštaišu izlokšṇu savienỉbas izveidi, ko pamatojot kopīgas iezīmes visos valodas lìmeņos, savukārt Anna Stafecka (Rīga), referējot par Latgales rokraksta literatūras dialektālo specifiku, minēja daudzus lietuviešu kolēgiem līdz šim mazāk zināmus faktus.

Arī Lietuvā, tāpat kā visur pasaulē, līdztekus dialektologijai pastāv un attīstās tāda relatīvi jauna nozare kā sociolingvistika, taču ar būtisku norādi, ka tā ir t.s. "liaudies kalbotyra" (tautas valodniecība) jeb neprofesionālā lingvistika (līdzīgi kā psiholingvistika, etnolingvistika u.tmi.). A.Jonaitītes jubilejas seminārā vairāki valodnieki informêja par saviem galvenokārt sociolingvistiskā aspektā veiktiem pētījumiem: Kazimiers Župerka (Šau|i) aplūkoja apvidvārdus ar metavalodas komentăru nevalodnieciskos tekstos, Virgīnija Stankēvičiene (Kauña) Neringas iedzīvotāju valodiskās atškiriribas, Regīna Kvašĭte (Rịga, Šauḷi) Latvijas lietuviešu dzimtās valodas īpatnības, konkrēti Bukaišu pagastā, bet Rita Umēžūte (Vi|ṇa) dzimtās valodas lietotāju kodu maiṇu, galvenokārt Jonišķu izloksne्.

Kopumā Šauḷos aizvadītā karstā aprīla diena vēlreiz apliecināja latviešu valodniekiem starptautiskās pieredzes apmaiṇas noderīgumu; par to paldies semināra rikkotājiem K.Župerkam, G.Čepaitienei, J.Švambarītei, G.Kačuškienei un pārējiem. Tā apstiprināja arī lietuviešu valodniecîbas klasiḳa Jona Jablonska atziṇu "Kalboje tauta pasisako, kas esanti, ko verta" (Valodà tauta izsaka sev savu esamību un savu vērtỉbu).

Agris Timuška 


\section{ZINĀTNISKĀ KONFERENCE RĒZEKNẼ}

23. aprīlī Rēzeknes Augstskolas Humanitārā fakultāte rīkoja gadskārtējo zinātnisko konferenci, kur latviešu valodas un literatūras sekcijā tika nolasīti vairāki referāti par valodniecības jautājumiem.

Andrejs Bankavs (LU Svešvalodu fakultāte) analizēja latviešu regionālās leksikogrāfijas lomu, īpaši akcentēdams Rēzeknē izdotās vãrdnīcas, vienīgos leksikogrāfijas avotus latgaliešu rakstu valodā (Ed.Kozlovska Krīwu - latgališu - wocu vordinica, 1918 un P.Stroda Pareizraksteibas vōrdneica, 1933).

$P \bar{c} c$ izdošanas vietas reǵionālie leksikogrāfiskie avoti iedalāmi 3 grupās:

a) vārdnīcas, kuras izdotas ārpus Rīgas (Valmiera, Jelgava, Limbaži, Rēzekne, Bulduri, Liepāja, Daugavpils, Cēsis utt.);

b) vārdnīcas, kuras nākušas klajā ārpus Latvijas (Viḷnā, Maskavā, ASV u.c.);

c) vairākvalodu vārdnīcas ar vairākām izdošanas vietām vienlaicīgi.

Latvijas regionālās leksikogrāfijas pirmsākumi meklējami ārpus tās teritorijas un tie saistās ar G. Elgera vārdu, kurš 1683. gadā Vi|ṇā izdeva Polu latīnu -latviešu vārdnīcu. Tai seko J.Kurmina (Vi|ṇa, 1856), Kr.Valdemāra (Maskava, 1872), M.Miežiṇa (Tīlzite, 1894) u.c. sastādìtās svešvalodu vārdnīcas. Pašreiz reǵionāāās leksikogrāfijas īpatsvars ir 4,6\% no visām vārdnīcām.

Lidijas Leikumas (LU Filologijas fakultāte) pētījuma centrā bija Latgales oikonīmu problēmas. Autore norādīja uz virknj neprecizitāšu apvidvārdu fiksēšanā dažādos latviešu valodas rakstītos avotos Latgalè, kas pamatã radušās, neprasmīgi pielāgojot toponīmus fonētiskajai un pat morfologiskajai sistēmai vai arī pastāvot slāviskajam iespaidam. Dałā ciemu nosaukumn vērojamas svārstības dzimtes lietojumā, dą̣a ofíciālo nosaukumu nesakrīt ar tautā lietotajiem. 
Ilga Jansone (Latviešu valodas institūts) analizēja Kristofora Fīrekera devumu valodniecībā un literatūrā. Literatürā Kr. Fīrekers devis ap 180 dziesınām, no kurām lielākā dạa bijušas vācu autoru reformācijas laika garīgās dzejas tulkojumi latviešu valodā. Vị̣š iedibinājis arī latviešu sillabotoniskās dzejas tradīciju. Valodniecībā Kr. Fīrekers devis deklināciju un konjugāciju apskatu, kā arī atstājis vārdnīcas manuskriptus, kurus laidis klajā 1997 un 1998. gadā T.G. Fennels. Kr. Fīrekers bija pirmais, kas sagatavoja tulkojošo vārdnīcu ar latviešu valodu pirmajā aktīvajā da|ā un tas bija 17.gs.beigām izcils leksikogrāfisks sasniegums. Vārdnīcas manuskriptā iek|auts bagāts leksiskais un frazeologiskais materiāls (leksēmu skaits sasniedz 6000-7500). Autors pirmais ieviesis plašu leksikogrāfisko norāžı sistēmu ar mērḳi sniegt papildinformāciju par leksēmu izplatīibu, cilmi, gramatisko piederību u.tml. Kr. Fīrekers īpaši izdalījis vārdus, kuri raksturīgi Kurzemei un Zemgalei, atsevišķos gadījumos arī Lietuvai. Etimologiskãs norādes attiecas faktiski uz germānismiem. Gramatisko kategoriju, vārdu semantikas un citu lingvistisko un ekstralingvistisko parādību atspogu|ošanai vãrdnīcas manuskriptos nereti izmantotas latīṇu valodā rakstītas norādes.

Inetas Kristovskas (Rēzeknes augstskola) referāts bija veltīts dzimtās valodas apguves problēmu noteikšanai Latvijas vidusskolās. Referente izvirzịja virkni cēloṇu, kas ir pamatā skolēnu nekvalitatīvajāin zināšanām, resp. valstiskās, skolas un skolēnu attieksmes.

Pie valstiskāin problēmām I.Kristovska pieskaita latviešu valodas lomas samazināšanos, latviešu valodas formas nonicināšanu, skolotāju darba nenovērtēšanu un nepopularitāti.

To problēmu vidū, kuras rada skolas un skolotāji, jāpiemin skolotāju trūkums, gramatikas lomas pārvērtěšana, skolēnu zināšanu novērtēšanas nepareiza orientācija, samazinātas prasības un vidusskolās disproporcija starp latviešu literatūras un valodas pasniegšanu.

Dodot ieskatu par tāın problēmām, kuras raksturīgākas skolēniem, tiek izdalītas skolēnu negatīvā attieksme pret 
mācīšanos, kāa rezultātă pazeminās vinuu vispārējās attīstības līmenis, pārliecība par vidusskolas absolvēšanu, citu informācijas avotu izmantošana, kas neveicina literatūras lasīšanu. Pēc vidusskolas beigšanas absolvents nereti sāk veidot valsts politiku, paužot savu attieksmi arī pret valodu un izglītibu vispār.

Mağistrante L.Cirša (Rēzeknes augstskola) detalizēti aprakstīja valodnieciskos izdevumus pēc 1918 .gada ortogrāfijas konferences, bet, savukārt, L.Pavlovskas (Liepājas Pedagogiskā

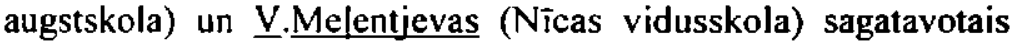
referāts bija veltīts frazeoloğijas pasniegšanas praktiskajiem jautājumiem sastatījuma (krievu un latviešu valodas) aspektā.

Rẽzeknes augstskolas 4. zinātniskajā konferencēe nolasītie referāti tiek apkopoti izdošanai atsevišksā krājumā.

Andrejs Bankavs

\section{RISINOT EIROPAS VALSTU TERMINOLOĢIJAS PROBLEMAS}

Krāšṇajā Ungārijas galvaspilsētā Budapeštā no š. g. 20. līdz 22. maijam notika starptautiska konference "Celā uz Eiropas terminolog̀iju", ko organizēja Ungārijas Modernās filoloǵijas biedrība un Ungārijas Lingvistikas biedrības Modernās filologijas departaments. Terminologijas problēmu risināšanā Ungārijai ir ciešas saites ar Vīnes terminoloǵijas centriem. Ungārijā tiek îstenoti visi galvenie mūsdienu terminoloǵijas attīstības principi, kāđi aktuāli arī citās valstīs.

Konferences darbs tika organizēts sekcijās, katru rīta un pēcpusdienas sesiju icvadīja visiem kopējs plenārsēdes referāts. Svarīgākie atzinumi bija ieklauti Vīnes universitātes profesora Radoslava Katičiča, Ungārijas Modernās filologijijas profesora Dimitrija Stefanoviča un Amerikas ungāra Budapeštas universitātes profesora Franka Tibora referātos.

Interesanti fakti bija iekḷauti F Tibora referātā. ASV ir milzīga emigrantu datu bāze, kurā ir arī dzimtu koki (tie ir 
publicēti grāmatā). Loti svarīga tautām - identitātes problēma. Galvenais kam cilvēks jūtas piederīgs. Dažāados laikmetos valstu robežas ir bijušas atšḳirīgas. Ir apkopota mikrogrupu terminologijjas vārdnīca. Dienviditālijas iedzīvotāji raksturoti kāa impulsīvi, nepaḳāvīgi, neorganizēti, tāpēc no turienes nāk mafija.

Būtiska ir F Tibora doma, ka terminologijas problēmas nav tikai lingvistikas problēmas. No terminologijas atkarīgs, kā cilvēks ko uztver, kā izprot savu piederību (sal. terminus: sitizenship, coumtry of origin, country of residence, birth country).

Liela da|a referātu bija veltīta serbu, slovēṇu, ungāru un citām tā reǵiona valodām. Referātos jūtams gandarījums par iespēju patstāvīgi attīstīt savu valsti un valodu. Katrai valodai raksturīgi aizguvumi, tomēr dominē tendence jaunāko terminologijiju veidot uz dzinntās valodas bāzes. Piemēram, serbu valodā ir $21 \%$ latīnismu, $16 \%$ ungārismu, $10 \%$ germānismu. Turku vãrdu agrāk bija vairāk, tagad daudzi no tiem aizstāti ar serbu vārdieın, arī vecvārdiem. Aizgūstot kā svarīga prasība ir nedeformēt savas valodas morfolog̀isko sistēmu.

Latvijas terminologu pieredze konferncē tika pārstāvēta 3 referātos. I.Pūtele referēja par latviešu arodnosaukumu veidošanas principiem vēsturiskā skatĩjumāa, R.Kvašīte - par lietvedības terminologijas attīstību, V.Skujiṇa - par mūsdienu juridiskās un uzṇēmējdarbības terminologijas attīstību.

Poḷu valodnieka Andžeja Kustra referātā piesaistijja atziṇas, kas skāra aizguvumu un arī pašu cilvēku adaptācijas problēmas. Parasti vārdus aizgūst vispirms runas līmenī, tāpēc arī pieraksta aizguvumus pēc to izrunas oriğinālvalodā. Taču originālvalodas forma ir tikai viena puse. Bez tam svarīga loma aizguvējvalodas fonētiskajai sistēmai. Tā kā A.Kustra dažus gadus pavadījis ASV, referātā tika skarti arī daži cittautiešu adaptācijas aspekti. lebraucēji vispirms cenšas amerikanizēties, bet vienā brīdī pārorientējas uz savas identitātes izpratni un vēlmi to saglabāt. 
Galvenais konferences devums - citu valstu (cita regiona valstu) pieredzes apgūšana, informācija par to, kã līdzīgi jautājumi tiek risināti citur.

Valentīna Skujina

\section{KĀRTĒJĀ BALTIJAS STUDIJU KONFERENCE ASV}

No š. g. 19. līdz 21. jūnijam ASV Indiānas štata Blūmingtonā notika Baltijas studiju attīstības asociācijas AABS (Association for the Advancement of Baltic Studies) rīkota 16. Baltijas studiju konference "Baltijas jautājumi intemacionālā skatījumā" Konferences dalībnieku (kopskaitā pāri par 200) vidū bija jūtams lietuviešu pārsvars, bet vismazāk bija igauṇu. Pārsvarā dalībnieki bija no ASV Latviju pārstāvēja 7 dalībnieki: Daina Jurika, Regina Kvašĭte, Ilze Lokmane, Ẽvalds Mugurēvičs, Valdis Muktupāvels ar kundzi un Valentīna Skujiṇa. Konferences darba valodas skaitījās divas - anglu un vācu valoda, bet praktiski viss notika ang]̣ valodā.

Darbs notika 8 sekcijās, 4-5 no tām vienlaicīgi.

Konference tika atklāta ar plenārsēdi, kurā tika teiktas ievadrunas, bet kopēja referāta nebija. Visi referāti tika lasīi sekcijās atbilstoši sekciju tematikai.

Valodniecības sekcijas darbs sākās ar Austrālijas valodnieka prof. Trevora G.Fennela referātu par inovācijām latviešu gramatikās 1685.-1761. g. Kā novērojis T.G.Fennels, pirmās latviešu gramatikas galvenokārt tiek kritizētas par neprecizitātēm materiāla izklāstā, taču mazāka uzmanība tiek pievērsta šo neprecizitāšu cēloṇiem. Tiek aizmirsti 2 faktori: 1) šie darbi vispăr bija pirmie šāda veida darbi, 2) tas bija ortodoksālās gramatikas periods, kad latīṇu valoda tika uzskatīta par universālu lingvistikas un logiskās struktūras modeli. Par tā laika inovãcijām jāatzīst latviešu valodas lietvārdi ar -is, ar kuriem, izdalot tos atsevišķā tipā (kategorijā), M.Bihners aizstāja iepriekš P.Einhorna aplūkoto grupu ar -ns, kā arī lietvārdi ar -us. Tas tādējādi nozīmēja latīnu valodas 5 deklināciju mode|a 
robežu pārkāpšanu. Par pirmo soli aiziešanā no latīnuu gramatikas diktāta T.G.Fennels atzīst H.Adolfi gramatiku (1685.g.). Savukārt 18. gs. vidũ par Vecā Stendera nopelnu minēta lokatīva atzī̌sana par patstāvigu locījumu (nevis ablatīva paveidu).

Baiba Metuzāle-Kangere (Stokholmas universitāte) savu referātu veltīja latviešu gramatikas problēmām Valža Zepa antididaktikā, analizējot vēl nepublicēto un publicēšanai neparedzēto Vałža Zepa manuskriptu "Runājat latviski?" Pirms 2 gadiem mirušais latviešu valodnieks šajā manuskriptā pauž ìpatnēju pieeju valodas mācīšanā, pamatojoties uz teikumu (izteikumu) kā lingvistiskās darbības pamatvienību. V.Zepa pieeja ir pretrunā ar parastajām didaktiskajām normām, toties, analizējot prāta darbības veiklumu, neaizvaino pieaugušo skolēnu (learner) intelektu.

Ilze Lokmane (Latvijas Universitāte) runāja par konteksta ietekmi uz teikuma struktūru, meklējot atbildi uz jautājumu, kas ir teikums. Par runātā un lasîtā teikuma intonāciju savus vērojumus darīja zināmus Dzintra Bonda (Ohaio universitāte). Rainers Ekerts (Berlīne) pievērsās nominalizācijas tendencei latviešu tautasdziesmu valodā. Regīna Kvašīte (Rīga, Šau|i) aplūkoja internacionalizācijas tendences lietišķo rakstu tulkojumos. Valentīna Skujina analizēja latīnu un grieķu cilmes elementu vietu latviešu valodas vārdu pamatfondā, uzsverot internacionālismu strukturāli semantisko modeḷu izpētes nozīmi starptautiskajā saskarsıne

No lietuviešu valodniekiem visspilgtāk atmiṇā palikušas Egles Ivinskienes (Čikāgas Ilinoisas universitāte) atziṇas par valodas nāves polemiskajiem aspektiem īpatnējā traktējumā. Autore secina, ka valodas miršana nav saistita ar valodas pazīmēm, īpatnībām, bet gan ar valodas lietošanu vai nelietošanu un prestižu.

Tautas garīguma spēka gaisotnē risinājās saruna par diasporas un dzimtenes tautiešu attiecībām Intas Gāles Karpenteres vadītajā atklātajā forumā estētikas, kultūras un saskarsmes sekcijā. Neuzspēlēti, issti, lietišķi, savstarpējā cieņā un saskañā. $K \overline{\mathbf{a}}$ " $3 \mathrm{X} 3$ " nometnēs - ne tikai sarunu satura un 
noskaṇas ziṇā, bet arī paaudžu ziṇā, jo forumā piedalījās arī llzes Matīsas tikko runāt sākusī meitina.

Iejūtīgs, garīguma apdvests un sirsnīgs bija Valdim Zepam veltītais piemiṇas brīdis universitātes èkai līdzās esošajā kapelā. Ar Valža Muktupāvela kokles skaṇām un atceres vārdiem, ar AABS izpilddirektora Jāṇa Gaigu|a, Baibas Metuzāles-Kangeres, Valtera Nollendorfa un citu atmiṇām.

Konferencei veltītajā grāmatu izstādē dalībnieki varēja iepazīties ar literatūru par Baltijas valstīn - vēsturē, politolog̀ijā, literatūrā, folklorā, valodniecībā, mūzikā.

Konferences noslēguma funkcija bija kopīgajam svinīgajam banketam, kurā tika godināti AABS vadītāji un konferences rīkotāji. Ar savu sniegumu pasākumu bagātināja Egles Ivinskienes vadītā lietuviešu folkloras ansamb|a "Delčia" koncerts. Saistoši bija arī literātes Agates Nesaules stāstījumi un lasījuıni literārajā sarīkojumā.

Indiānas universitātes mājīgās telpas, plašais un labi koptais universitātes parks un ēku savdabīgā arhitektūra, konferences organizētāju un dalībnieku allaž gaišie smaidi, laipnība, labsirdība un visu pasākumu korektā organizāijja un pārdomātība atstāj paliekošu iespaidu, kas, domājams, ilgi saglabāsies atmiñā līdz ar referātos dzirdēto atzinu rosinājumiem. Interesenti ar referātu tēzēm tuvāk var iepazīties kräjumā "Baltic Issues in International Perspective"

Valentina Skujina

\section{LITUĀNISTU IKGADĒJĀ KONFERENCĒ}

1998. gada 3.-4. jūlijā Viḷnā jau piekto reizi pulcējās Pasaules lituānistu asociācijas biedri. Šì organizācija ar lielu pacēlumu atdzinna Lietuvā 1994. gada vasarā kā turpinājums emigrācijā 1951. gadā dibinātajam Lituānistikas institūtam. Asociācija vieno pāri par 100 zinātnieku no dažādām pasaules valstīm. Ikgadējo konferenču mērkis dalīties informācijā humanitārajā jomā, mazināt tā saucamos "baltos plankumus", kā 
arī stiprināt sakarus starp dažādu nozaru lituănistikas pētniekiem.

Šogad šis asociācijas konferences galvenā tēma bija veltīta starpdisciplinārajiem sakariem. Tika izskatīti trīs lieli problēmu loki: "Starpdisciplīnu kontakti teorētiskā aspektā", "Interdisciplinaritāte vēsturiskos pētijumos" un "Starpdisciplinārās metodes mūsdienu kultūras analìzē", nolasīti 22 referāti.

Dažãdu humanitāro disciplīnu iespējamo mijiedarbi savā referātā oriğināli (demonstrēdams skulptūru un skandēdams dzeju) parādīja literalogs K. Nastopska (Vi|ñas universitāte). Par kultūrdisciplīnu dialogu runāja arī jaunie zinātnieki kultūrologs $\underline{A}$.Samalavičs un vēsturnieks $\underline{V}$. Berenis (abi pārstāvēja Kultūras un mākslas institūtu). Lituānistikas un sociālo zinātñu pētniecības kopīgos saskarsmes punktus savā

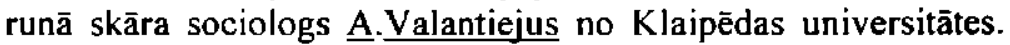
İpaši valodas un literatūras zinātnes integrācijas procesu ieskicēja valodnieks $\underline{\mathrm{V}}$.Labutis (Vilñas universitāte). Jauns zinātnieks A. Tereškins, kas pārstāvēja Harvardas universitāti (ASV) runāja par jaunu vēsturisku skatījumu lietuviešu kultūras studijās (pēc viṇa domām, ir jāpievērš uzmanība neparastajam, dīvainajam, līdz šim nepamanītajam).

Daudz jautājumu un asu domu apmaiṇu izraisija vēsturiskās tēmas ziṇojumi (P.Batūra - VPI, K. Gudmants - VU, R.Apanavičs - VDU, A.Nepokupnijs - Kijeva).

Par starpkultūru komunikatīvo nozīmību stāstīja kultūrvēsturnieks, orientālists $\underline{\text { R. Neimants }}$ (VDU), par starpkultūru komunikāciju, mācot lietuviešu valodu

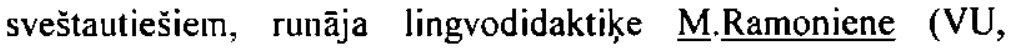
Helsinku universitāte). Sastatīdams emigrăcijas autora J.Meka moderno dzeju un videofilmu mākslu, semiotikas problēmās iedziḷinājās VU Semiotikas centra vadītājs $\underline{\text { S}}$.Žuks.

Atsevišķa sēde konferencē bija veltīta lituānistisko studiju datorizācijas iespējām (‥Černausks, ‥Žilinskiene MII, V.Savonakaite LIl, $\underline{R}$.Marcinkevičiene VDU). Tika pārrunāti arī aktuālie datorterminu jautājumi. 
Informativa rakstura ziņojumu par jaungatavojamo Lietuviešu vispārīgo enciklopēdiju nolasīja J G.Girdzijausks.

Vislielāko konferences klausītāju un dalībnieku interesi izraisīja diskusija par humanitāro zinātṇu politiku Lietuvã. Diskusijā piedalījās arī Lietuvas Republikas lzglītỉbas un zinātnes ministrs K.Platelis. Galvenokārt tika spriests par iecerētajām zinātnisko iestāžu reformām. Pašlaik Lietuvā ir 15 augstskolas un 29 zinātniskie pētniecības institūti. Runātāji bija vienisprātis, ka reformas, lai padzilinātu un aktualizētu zinātnisko iestāžu darbu, ir nepieciešaınas, bet vai vienīgais reformu ce|š ir augstskolu un institūtu integrācija - te domas dalījās. Diskusijas dalībrieki ieklausîjās arī kaimiṇvalsts Latvijas pieredzē šajā problēmiskajā situācijā. Diskusijās daudz kaislību uzliesmoja, arī runājot par jaunās ekspertu komisijas slēdzienu, vērtējot humanitāros institūtus pēc eksakto institūtu vērtēšanas kritērijiem. Tika apšaubīta citējamības koeficienta lietderība: izskanēja Amerikas un Polijas zinātnieku atziṇa, ka lielākoties tiek citēti darbi, kas rada vislielākās šaubas (turklāt arī šī kritērija sakarā ir vērojams protekcionisms, resp., "draugu būšana"). Daudzi runātāji bija neizpratnē arī par prestižo zinātnisko izdevumu publikācijām (izskatās, ka prestižie humanitārie žurnāli ir tikai ārzemēs...). Interesanti, ka visas problēmas, par kurām runāja lietuviešu zinātnieki šajā diskusijā, kā divas ūdens lāses līdzīgas tām, par kurām tiek lauzītas galvas arī Latvijas zinātnieku aprindās. Varbūt kopīgièn spēkiem tās vieglāk varētu atrisināt?

Vēl dažas aktuālas sentences, izskanējušas šajā konferencē:

- "Šaurs prāts ved uz intelektuālo geto."

- "Nav lielākas nelaimes kā naids pret vārdu."

- "Mūsu valodā jūtama svešas valodas ēna, svešas valodas dvēsele."

- "Pašreiz mēs dzīvojam tūkstoš un vienas nejēdzības valstī."

- "Ikvienas konferences galvenā sastāvdala ir starpbrīži." 


\section{ZINAS PAR AUTORIEM}

Andrejs BANKAVS (1945) Dr.habil.philol., LU profesors, Svešvalodu fakultātes Romāñu valodu katedras vadītājs.

Maija BRĒDE (1945) Dr.philol., LU Svešvalodu fakultātes Sastatāmās valodniecības katedras docente.

Brigita BUSMANE (1939) - Dr.habil. philol., LU Latviešu valodas institūta vadošā pētniece.

Giedrè 'ČEPAITIENÉ (1953) Dr.human., Šaulu universitātes Humanitārās fakultātes docente.

Inese EDDEMANE (1936) Dr.philol., LU Latviešu valodas institūta vadošā pētniece.

Juris GRIGORJEVS (1966) - Mg.philol., LU Filologijas fakultātes Baltu valodu katedras asistents.

Ilga JANSONE (1958) - Dr.philol. LU Latviešu valodas institūta vadošā pētniece, direktora vietniece.

Genovaitė KAČIUŠKIENĖ (1954) Dr.human., Šaulu universitātes Humanitārās fakultātes dekāne.

Elga KAGAINE (1930) Dr.habil.philol., LU Latviešu valodas institūta vadošā pētniece.

Andra KALNAČA (1965) Dr.philol., LU Filologijas fakultātes Baltu valodu katedras lektore.

Sarmīte LAGZDIN̦A (1944) Dr.philol., LU Latviešu valodas institūta pētniece.

Benita LAUMANE (1937) - Dr.habil.philol., Liepājas PA profesore.

Gunta LOČMELE (1961) Dr.philol. LU Svešvalodu fakultātes Sastatāmās valodniecības katedras docente.

Daina NĪTIN̦A (1942) - Dr.habil.philol., RTU profesore.

Olga OZOLINA (1944) Dr.philol., LU Svešvalodu fakultātes Romāṇu valodu katedras docente. 
Anna STAFECKA (1953) Dr.philol., LU Latviešu valodas institūta vadošā pētniece.

Māra SNĒ (1970) Mg.philol., LU Latviešu valodas institūta asistente, LU doktorante.

Agris TIMUSKA (1961) - Dr.philol., LU Latviešu valodas institūta vadošais pētnieks.

Andrejs VEISBERGS (1960) Dr.habil.philol. LU profesors, Svešvalodu fakultātes Sastatāmās valodniecības katedras vadītājs.

Ieva ZAUBERGA (1958) Dr.philol., LU Svešvalodu fakultātes Sastatāmās valodniecības katedras docente. 


\section{LINGUISTICA LETTICA 3}

Salikts LU Latviešu valodas institūtā Iespiests Latvijas - Somijas SIA "Madonas poligrāfists" Metiens 500 eks.

Pasūtījuma Nr. 1817 